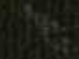

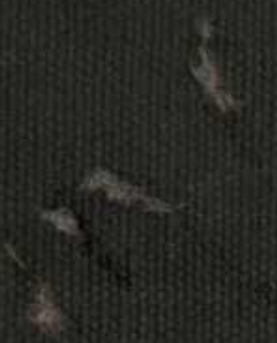

153. 


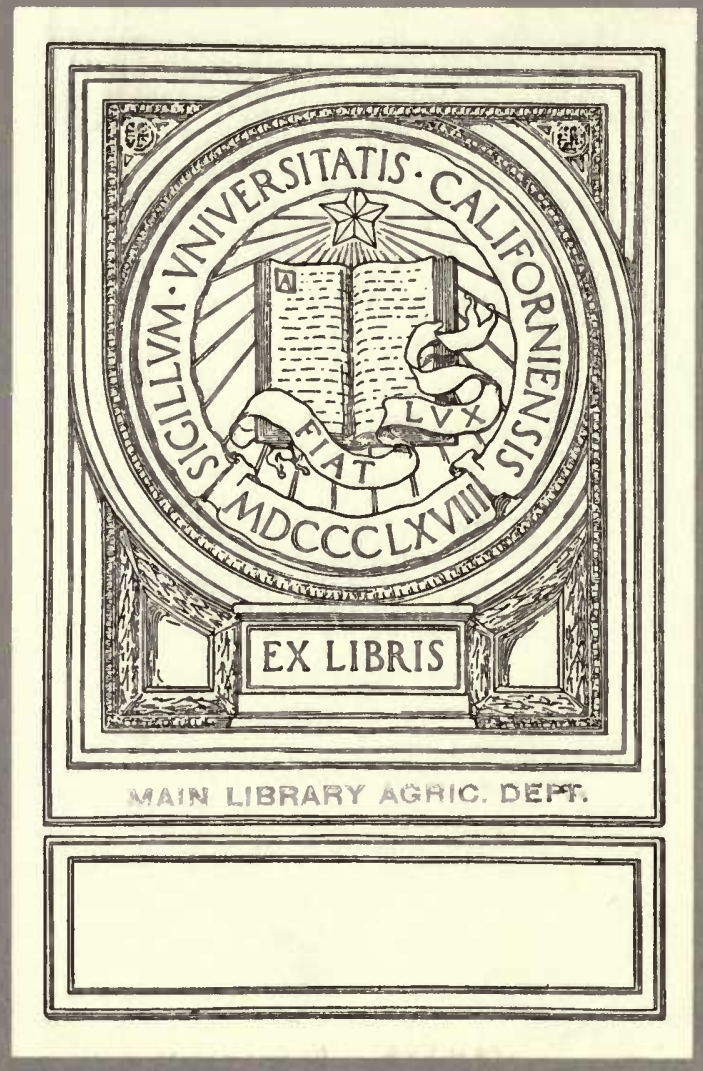







\section{THE GARDENS OF}

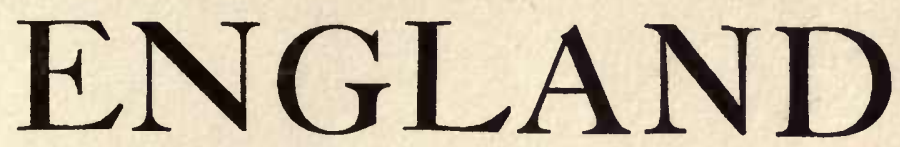

\section{IN THE \\ SOUTHERN \\ \& WESTERN \\ COUNTIES}

EDITED BY CHARLES HOLME

DEPT. OF AGRICULTURE

DIV. OF AGR'L EUVCATION

MCMVII

OFFICES OF "THE STUDIO”

LONDON, PARIS \& NEW YORK 
Main 1.t.

figric Deys

$$
a_{0} e^{e^{2}}
$$

1 


\section{PREFATORY NOTE}

ThE Editor desires to acknowledge his indebtedness to the owners, whose names appear under the illustrations, for the valuable assistance they have rendered him by allowing their gardens to be represented in this volume. Special facilities have been accorded Mr. W. J. Day, the photographer-whose excellent work is familiar to readers of The STudio-whereby he has been enabled to obtain, exclusively for this work, the extensive and unique series of garden subjects here illustrated. The Editor also wishes to acknowledge the help given to Mr. Day by the head gardeners.

To Her Grace The Duchess of Bedford, Miss E. H. Adie, Mr. George S. Elgood, R.I., Mr. E. Arthur Rowe, Mr. H. G. Seaman and Miss Lilian Stannard the Editor tenders his cordial thanks for the loan of the drawings reproduced in colour. 


\section{ARTICLES}

The History of Garden-making . . . . . page i The Principles of Garden-making . . . . " Notes on the Illustrations . . . . . . \# xxxi

\section{LIST OF ILLUSTRATIONS IN COLOUR}

Plate

Subject

Artist

I. The Forecourt, Great Tangley after George S. Elgood,

$$
\text { Manor, Surrey }
$$

R.I.

xx. Yew Arch at Brickwall, Sussex ", xxxv. "Early Autumn Tints". . " Lilian Stannard

LIv. Grass Walk at Hampton Court " Lxix. "A Summer Evening" . . " Lxxxvi. The Long Water, Hampton " Court

CV, Penshurst, Kent . . . " " cxx. "An Old Garden" . . " Lilian Stannard 


\section{LIST OF PHOTOGRAPHS}

Plate

II. The Water Garden at Abbotsbury Castle, Dorset

III.

Iv. Garden "Grates at Ammerdown Park, Somerset

v. Ammerdown Park, Somerset

vi. Sheltered Seat at Ammerdown Park, Somerset

vir. Ammerdown Park, Somerset

VIII.

Ix. The "Water Garden at Ashridge Park, Herts

x. The Rockery Walk at Ashridge Park, Herts

xI. Gardener's Cottage at Ashridge Park, Herts

xir. The Monk's Walk, Ashridge Park, Herts

XIII. Italian Garden and Orangery at Ashridge Park, Herts

xiv. The Garden Entrance at Beaulieu Palace, Hants

$\mathrm{xv}$. Blenheim Palace, Oxon

$\mathrm{XvI}$. The Rose Garden at Blenheim Palace, Oxor

xvir. Bronze Fountain at Blenheim Palace, Oxon

xviri. The Lion Fountain at Blenheim Palace, Oxon

xIx. The "Rose of Sharon" Bank at Blenheim Palace, Oxon

xxr. Cascade at Bowood Park, Wilts

xxir. The Terrace Steps at Bowood Park, Wilts

xxiri. The Hall, Bradford-on-Avon, Wilts

xxiv. Pergola at The Hall, Bradford-on-Avon, Wilts

$x x v$. Portugal Laurel at Broadlands, Hants

Xxvi. Entrance to the Orangery at Broadlands, Hants

xxvir. The Wall Garden at Brockenhurst Park, Hants

xxviII. The Dutch Garden at Brockenhurst Park, Hants

xxix. Brockenhurst Park, Hants

xxx. " " "

Xxxi. Brympton House, Somerset

xxxir. Terrace Steps at Brympton House, Somerset

xxxirr. Canford Manor, Dorset

xxxiv. " " "

xxxvi. Swiss Cottage at Chaddlewood, Devon

xxxvir. Ivy-clad Summer-house at Chaddlewood, Devon

xxxvirr. Summer-house at Clevedon Court, Somerset

xxxix. The Terrace at Clevedon Court, Somerset

xL. Below the Terrace at Clevedon Court, Somerset

xLI. The Park Entrance at Corshan Court, Wilts

xuIr. The Rose Garden at Corsham Court, Wilts

vi
Owner

Mary,Countess of Ilchester

Lord Hylton

$\begin{array}{ll}M & \text { " } \\ \text { " } & \end{array}$

The Earl Brownlow

$\begin{array}{ll}" & " \\ " & " \\ " & "\end{array}$

Lord Montagu of Beaulieu

The Duke of Marlborough

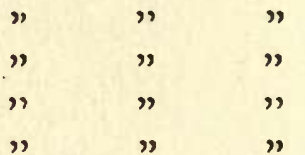

The Marquis of Lansdowne

J. "Moulton, Esq.

" " "

Rt. Hon. Evelyn Ashley

E. J. Morant, Esq.

$\begin{array}{lll}" \prime & " & \end{array}$

Sir S.C. B. Ponsonby-Fane

Lord Wimborne

G. Soltau-Symons, Esq.

" " "

Sir Edmund Elton, Bart.

9

")

")

"

General Lord Methuen

")

ท 


\section{LIST OF PHOTOGRAPHS}

Plate

xLIIr. Corsham Court, Wilts

xuIv. Garden Entrance at Daw's Hill Lodge, Bucks

xuv. The Garden Front at Daw's Hill Lodge, Bucks

XIVI. Loggia at Dropmore, Bucks

xLvir. Alcove Seat at Dropmore, Bucks

xuvirr. Lily Pool at Dropmore, Bucks

xurx. Garden Pensioner's Cottage at Eggesford House,

Devon

L. Ancient Cross at Eggesford House, Devon

L. Cromwell's Seat at Embley Park, Hants

uIr. The Cedar Walk at Embley Park, Hants

LIII. Embley Park, Hants

Lv. Garden Gateway at Eridge Castle, Sussex

Lvi. Eridge Castle, Sussex

uvrr. The Cedars of Lebanon at Farnham Castle, Surrey

Lvirr. Great Tangley Manor, Surrey

LIx. The Sundial Garden at Great Tangley Manor, Surrey

LX. Gardener's Cottage at Greenway House, Devon

LXI. Greenway House, Devon

LXII. Groombridge House, Sussex

Lxirr. The Lower Garden at Groombridge House, Sussex

LxIv. The Upper Garden at Groombridge House, Sussex

Lxv. The Garden Front at Ham House, Surrey

Lxvi. Thie Old Orangery at Ham House, Surrey

Lxvir. The New Water Garden at Hartham Park, Wilts

LXviII. The Water Garden at Hartham Park, Wilts

Lxx. Entrance Gate at Hatfield House, Herts

LXXI. A Corner of the Forecourt at Hatfield House, Herts

LXxir. The Maze at Hatfield House, Herts

Lxxiri. Old Garden Wall at Hatfield House, Herts.

Lxxiv. Seat on the Terrace at Hinton Admiral, Hants

Lxxv. Rock Garden at Hinton Admiral, Hants

Lxxvr. Pampas Walk at Hinton Admiral, Hants

Lxxvir. The Fountain Garden at Holland House, Kensington

Lxxvirr. Entrance to the Flower Garden at Holland House, Kensington

Lxxix. The Terrace Garden at Holland House, Kensington

Lxxx. The Orangery at Holland House, Kensington

Lxxxi. Terra Cotta Group at Holland House, Kensington
OWNER

General Lord Methuen

The Earl Carrington

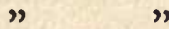

J. B. Fortescue, Esq.

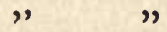

"

The Earl of Portsmouth

Major Chichester

$"$ "
The Marquis of Aber-
gavenny

" " "

The Bishop of Winchester

Colonel E. H. Kennard

" " "

T. B. Bolitho, Esq.

The Misses Saint

9)

" $"$ "

The Earl of Dysart

Sir John" Dickson-Poynder, Bart.

The Marquis of Salisbury

$" \quad " \quad " \quad "$

Sir George Meyrick, Bart.

$"$ " " "

Mary, Countess of Ilchester

" $\quad$ "


Plate

Subject

Lxxxir. Sundial at Inwood House, Dorset

Lxxxirr. Killerton, Devon

Lxxxiv. The Rock Garden at Killerton, Devon

Lxxxv. Great Spanish Chestnut at Killerton, Devon

Lxxxvir. Sundial at Kingston Lacy, Dorset

Lxxxvin The Formal Garden at Longford Castle, Wilts

LXXXIX.

xc. The President's "Garden at Magdalen "College, Oxford

xcI. Montacute House, Somerset

xciI. The Upper Garden at Moor Park, Herts

xciri. The Formal Garden at Moor Park, Herts

xciv. Old Place, Lindfield, Sussex

xcv. The Garden House from the Lime Avenue at Old Place, Lindfield, Sussex

xcvi. Grass Path at Old Place, Lindfield, Sussex

xcvir. The Topiary Walk at Old Place, Lindfield, Sussex

xcvirI. View from the Terrace at Orchárdleigh Park, Somerset

xcIx. The Garden Front at Orchàrdleigh Park, Somerset

c. Herbaceous Flower Border at Orchardleigh Park, Somerset

cI. The Terrace at Orchardleigh Park, Somerset

cIr. The River Garden at Paulton's Park, Romsey, Hants

ciII. Old Venetian Well-head at Paulton's Park, Romsey, Hants

cIv. Penshurst Place, Kent

cvi. The Garden Entrance at Penshurst Place, Kent

cvir. Diana's Pool at Penshurst Place, Kent

cviri. The "Old Dial" Garden at Penshurst Place, Kent

cIx. The Formal Garden at Penshurst Place, Kent

cx. Garden Entrance at Pentillie Castle, Cornwall

cxi. Pentillie Castle, Cornwall

cxir. Window at St. John's College, Oxford

cxiII. The Palace, Salisbury, Wilts

cxiv. The Water Garden at Sedgwick Park, Sussex

cxv. " " " "

cxvi. Stratton Park, Hants

cXviI. - " "

cxviII. " "

cxix. The Upper Pond at Swaylands House, Kent

cxxi. The Formal Garden at Taplow Court, Bucks

cxxII. Taplow Court, Bucks

viii
OWNER

Lady Theodora Guest

Sir Charles Acland, Bart.

" " " "

Mrs. Ralph Bankes

The Earl of Radnor

" " "

The President

W. Phelips, Esq.

Lord Ebury

W. E. Tower, Esq.

" $\quad$ " $\quad$ "

Rev. W. A. Duckworth

" M M

,

Capt. R. " . H. SloaneStanley

Lord de L'Isle and Dudley

" "

" $"$ "

" "

", "

William Coryton, Esq.

The Warden

The Bishop of Salisbury

Mrs. Henderson

The Earl of Northbrook

" " " "

G. J. Drummond, Esq.

Lord Desborough

,9

99 
Plate Surject

cxxIII. Group of Topiary Work at Tring Park, Herts

cxxiv. The Lily Pond at Tring Park, Herts

cxxv. The Lily Pond and Grass Steps at Tring Park, Herts

cxxvi. Entrance to Garden Subway at Tring Park, Herts

cxxvir. The Lady Rothschild's Almshouses at Tring, Herts

cxxviri. Steps to the Park at Ven Hall, Somerset

cxxix. Ven Hall, Somerset

cxxx. Rose Garden at Ven Hall, Somerset

cxxxi. Wadham College, Oxford

OWNER

Lord Rothschild

cxxxir. Ilex Trees at Walhampton Park, Hants

cxxxıII. The Holbein Walk at Wilton House, Wilts

cxxxiv. The Italian Garden at Wilton House, Wilts

cxxxv. The River Path at Wilton House, Wilts

cxxxvi. Wilton House, Wilts

Hon. Mrs. A. Ker

" " " "

J. P. Heseltine, Esq.

The Earl of Pembroke

$\begin{array}{ll}" & " \\ " 1 & n\end{array}$




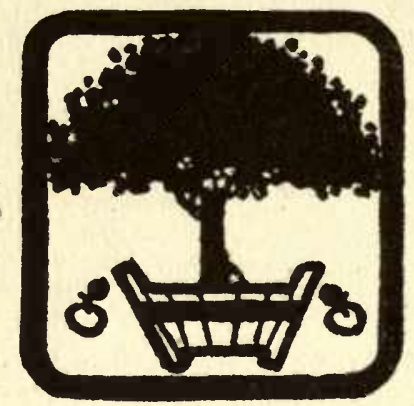


$\Rightarrow$ 


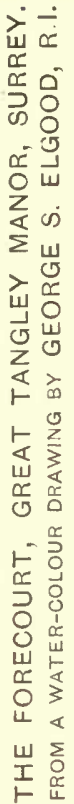

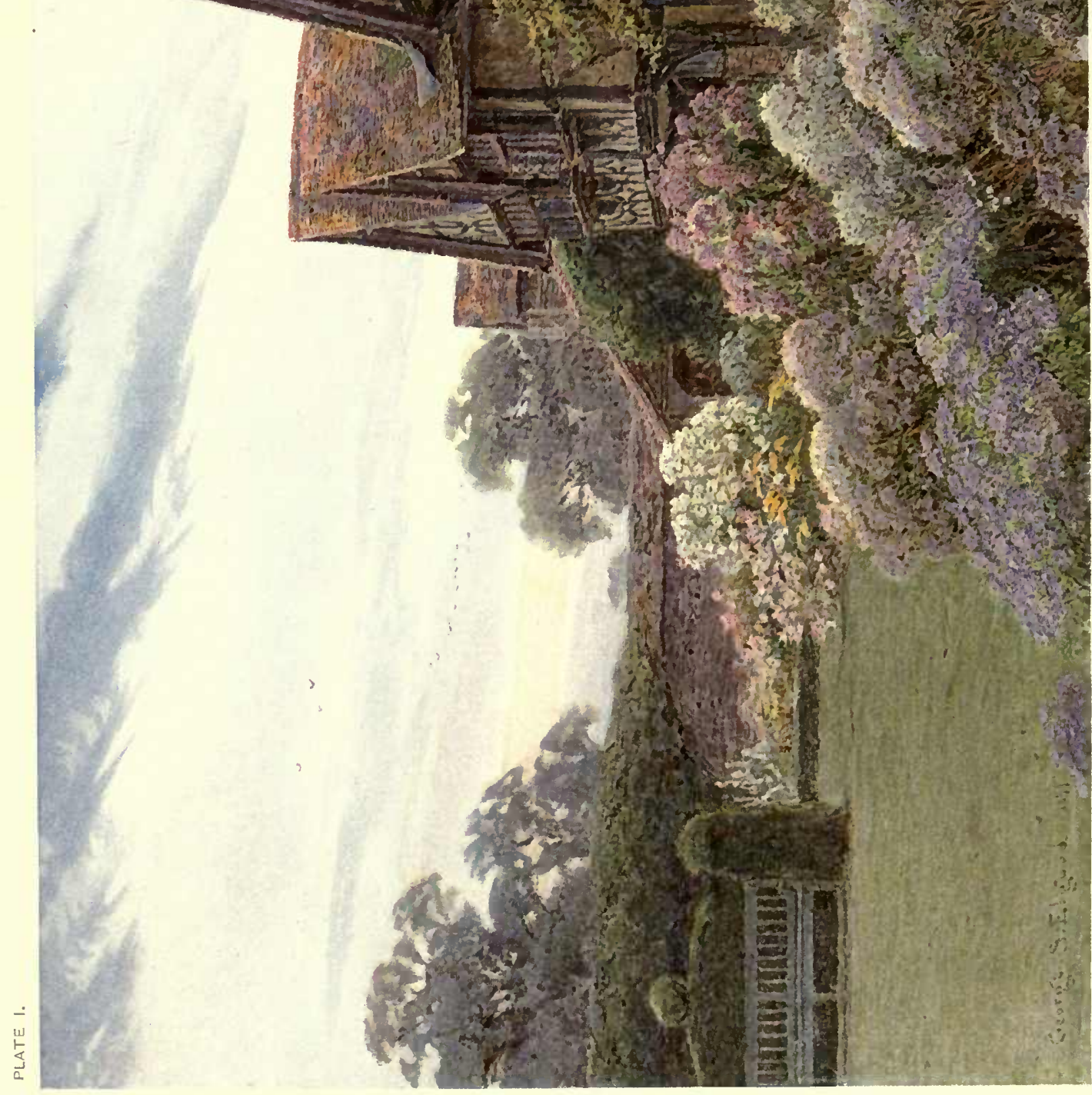

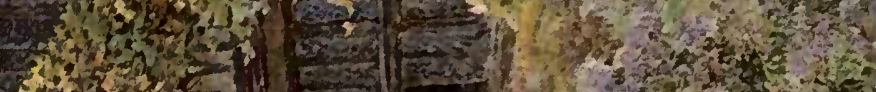

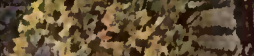
130,0 ,

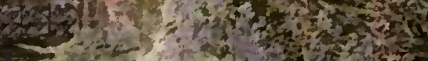

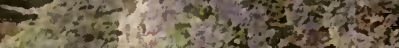

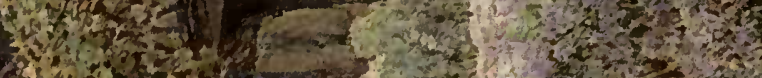

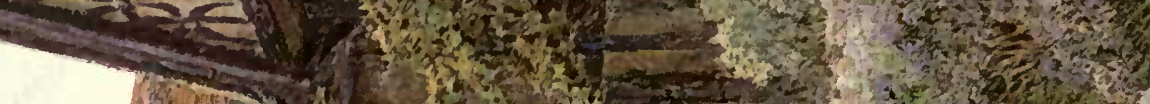




\section{THE HISTORY OF GARDEN-MAKING}

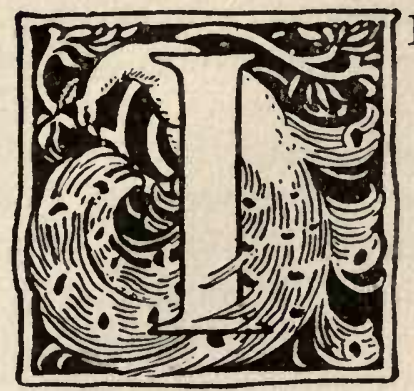

$\mathrm{N}$ attempting any detailed history of gardening and garden-making, the chief difficulty would be to decide where to begin. It is practically impossible to say where and at what date the idea first sprang up in the human mind that pleasure was to be derived from an ordered and deliberately planned surrounding of trees and flowers, or how the progression was made from cultivation of the ground for strictly utilitarian purposes to the planting of spaces in which leisure moments could be spent in frank enjoyment of nature. Probably, if material were available, such a history could be started at that remote period when man ceased to be merely a nomad, wandering here and there with his flocks and herds, and when, instead, he adopted some sort of permanent habitation. His first thought would be, when he had settled in the country he had chosen, to provide for his wants by growing those plants which were necessary for food, and by a natural process he would change from the purely pastoral life to that of the agriculturist. Next, he would seek to supply himself with those herbs and trees which, if not exactly necessities of existence, can be counted as more or less indispensable for human enjoyment; and to satisfy this desire he would add to his possessions the vineyard, the orchard, and the herb garden. Out of the wish to increase his material luxuries would grow, by an obvious sequence of ideas, the further wish to develop what asthetic instincts he might possess, and to use these instincts for selfgratification.

The garden, then, in its earliest form can be regarded as the result of an attempt to make a piece of cultivated ground pleasant to look at and agreeable to rest in. It was the shady place where the man who had laboured came for relaxation, where he turned for bodily comfort and the pleasure of the eye. In the East, the cradle of ancient civilisations, climatic conditions had to be considered, and the cool shadow beneath the fig-tree or the vine was a necessity to the jaded worker. So he planted his trees and trained his vines to give him shelter from the heat of the sun, he planned quiet nooks to which he could retire; and bit by bit he built up a garden which was frankly intended to be a place apart, set aside for repose and recreation. When he had once accepted the principle that this corner of the land he tilled should be recognised as a refuge in which 
he could forget the cares of his daily existence he sought to give it a charm of its own, to beautify it by flowers, to embellish it by cunning devices, and to make it by all the means at his disposal a kind of little shrine where he could offer incense to the goddess, Nature.

The first records of gardens systematically arranged and laid out on fixed principles are to be found in the works of Eastern writers. In Assyria, Persia and Egypt, the science of gardening was closely studied, and the principles on which the pleasure ground should be designed to fulfil its particular purpose were well understood. In India, too, the value of a garden setting to enhance the dignity of the palace or the temple was fully appreciated; the Indian rulers even in remote ages were garden lovers, and turned to full account the opportunities they enjoyed of shaping the luxuriance of tropical nature into ordered forms, and of adding to nature's beauties by bringing her into relation with architecture.

But the ancient history of gardening is by no means confined to the East ; in the West the Greeks and the Romans did much to develop the art, and the Romans especially carried it to a very high degree of completeness. The account written by Pliny the younger of his winter garden on the Bay of Ostia, and of his other garden at his Tusculan villa in the Apennines, gives an admirable suggestion of the way in which the wealthy and cultured Roman citizen surrounded himself with fantastic contrivances, and used all the resources of the gardener's craft to increase the attractiveness of the place in which he lived. The winter villa with its hedges of rosemary and box, its terraces, its vines, fig-trees, and mulberries, and its porticos and seats from which charming views could be obtained over land and sea, must have been a delightful retreat, and it is easy to understand the joy of ownership which is so apparent in Pliny's descriptions of his house by the sea. But it was the Tusculan villa upon which he lavished his attention, and to the adornment of which he devoted so much care and ingenuity.

The garden of this villa must indeed have been a marvel, so full was it of quaint and curious features, and so inventively were all its details devised. From the terrace before the house stretched a lawn ornamented with box-trees clipped into the shapes of various animals, and round this lawn ran a walk shut in by evergreens. Next came a circular enclosure with a group of clipped box-trees in the centre ; and near by was another enclosure in the form of a hippodrome with sides of alternate box and plane trees connected by ivy, and curved ends of cypress backed by bay-trees. The paths 
were bordered with roses and edged with box, and in the spaces between were all sorts of devices cut in box, and here and there obelisks or fruit-trees. Besides the trees and plants the garden abounded in architectural features-here an alcove of white marble draped with vines, there a summer-house with fountains and marble seats, and all about basins and streams of water, partly for ornament and partly for purposes of irrigation. Nothing was forgotten which could add to its beauty or increase its interest to the lover of nature. Yet it may be questioned whether Pliny's gardens were not equalled, or perhaps surpassed, by those of other Romans who shared his tastes. The representations which have been preserved of gardens of this date, and the descriptions which have been left by post-Augustan writers, prove that the formal planning of pleasure grounds, adorned with fountains, vases, statues, and other architectural additions, was extensively carried out wherever space permitted, and that in addition to formal planning a very definite formality was observed in the treatment of accessory details. The topiarius, who clipped trees into fantastic shapes, was much in request, and his work found ready acceptance among the Romans who had a mind to possess gardens which would be in the fashion of the period. A set and deliberate ordering of all the parts of the garden plan and a careful observance of accepted principles of design were recognised as essential, while within the limits which fashion imposed there was ample scope for the exercise of very pleasant fancy and very varied contrivance.

These Roman gardens are of particular interest because to them can be partly traced the origin of garden-making on formal lines in England. The gardeners of the Italian Renaissance modelled themselves upon their Roman predecessors, and re-introduced the clipped trees and the other architectural and semi-architectural features which had been so much in vogue centuries before. They sought to revive the dignity and classic grace of the earlier work, and to link up, by a certain continuity of methods, their practice with that of the past. The atmosphere they desired to create was that of studied elegance, severely perfect, and at the same time sumptuous and restrained, the atmosphere which makes itself felt in Hawthorne's description of the Medici Gardens :- "They are laid out in the old fashion of straight paths, with borders of box, which form hedges of great height and density, and are shorn and trimmed to the evenness of a wall of stone at the top and sides. There are green alleys with long vistas, overshadowed by ilex trees; and at each intersection of the paths the visitor finds seats of lichen- 
covered stone to repose on, and marble statues that look forlornly at him. In the more open portions of the gardens, before the sculptured front of the villa, you see fountains and flower beds; and in their season a profusion of roses, from which the genial sun of Italy distils a fragrance to be scattered abroad by the no less genial breeze."

The Renaissance influence began to be active in England during the earlier years of the sixteenth century, and though it was modified to some extent by the traditions already existing here it brought about some marked changes in English garden-making. What was the character of the work done by the earlier gardeners in this country cannot now be very exactly stated, in the absence of detailed records; but from some of the mediæval manuscripts in which illuminations of garden scenes are inserted it would appear that pleasure grounds laid out with a good deal of consideration for effect, and possessing many interesting features, were by no means uncommon. Hedges and shaded walks, fountains and little runnels of water, flower-beds planted in intricate patterns, arbours and seats, trellises covered with flowers, all set out within a space surrounded by a high wall, were the various parts which were welded together by the designers of the mediæval garden, and the result of this combination was apparently quite persuasive.

As a word-picture of a garden of this character the lines written by James I. of Scotland, when he was a captive at Windsor, in the early years of the fifteenth century, are worth quoting :-

\footnotetext{
"Now was there made, fast by the Tower's wall,

A garden fair, and in corneris set

Ane herbere green with wandes long and small,

Railit about, and so with treeis set,

Was all the place, and hawthorn hedges knet,

Thet lyf was non, walking there forbye,

That might therein scarce any wight espye-

So thick the boughis and the leaves green

Beshaded all the alleys that there were-

And myddis every herbere might be seene

The sharp, green, sweete junipere."
}

In this description there is implied a quite complete system of planning and the use of a regular pattern in the laying out of the ground occupied by the garden. Formality was evidently recognised as essential, alleys "beshaded" with closely grown foliage were contrasted with open spaces, and the different parts of the garden were defined and marked out one from the other by hedges and fences. Clearly there was nothing haphazard in the mediæval iv 
methods, and no idea of leaving Nature to work her will unassisted by human ingenuity.

It can be imagined that the introduction of Italian devices into a country which possessed already a sufficiently definite conviction about the principles of garden-making did not cause a mere destruction of a system which had been followed probably for some centuries. What resulted was rather in the nature of a compromise : new ideas were acquired from Italy, but in working out these ideas much that had served well the designers in the past was retained. At first the novelty of the Italian style gave it an amount of popularity which promised to make it all-pervading, and even its more extravagant peculiarities were generally adopted; as time went on, however, many of these extravagances were corrected, and by the welding together of the new methods and the old, a better way was found of satisfying the English taste. The Italian sumptuousness was accepted, but the quaintness of the mediæval work and its homeliness of manner were allowed to modify this sumptuousness into something not unduly artificial, and not excessively unnatural.

The full effects of this alliance were not seen until the seventeenth century. During the sixteenth the Renaissance garden, the Roman type revived, was made fashionable by the preference shown for it by Henry VIII., who not only employed Italians to lay out the grounds of his palace of Nonsuch, in Surrey, commenced in I 539, but also, in $153^{\circ}$, brought many Italian features into the gardens at Hampton Court, which had been treated by Wolsey in the mediæval English manner. One of the most notable gardens of this period was that at Theobald's, for Lord Burleigh. It was begun in 1560 , and from the description of it, written by the German traveller, Hentzner, who published in 1598 an account of his visit to England, it seems to have been designed quite closely on the Italian lines. "Close to the palace," he writes, "is a garden surrounded on all sides by water, so that anyone in a boat may wander to and fro among the fruit-groves with great pleasure to himself. There you will find various trees and herbs, labyrinths made with great pains, a fountain of springing water, of white marble; columns, too, and pyramids placed about the garden-some of wood, some of stone. We were afterwards taken to the garden-house by the gardener, and saw in the ground floor, which is circular in shape, twelve figures of Roman Emperors in white marble, and a table of Lydian stone." And further on he mentions a banqueting-room adjoining this garden-house and connected with it by a little bridge.

There is proof enough in such records that sixteenth-century 
gardening was made the subject of serious study, and that it was carried out on elaborate lines. How great was the attention it received can be judged from the number of books on garden-making written at this period. There was Dr. Andrew Borde's "Boke for to lerne a man to be wyse in buyldyng of his house for the health of his body, e to hold quyetnes for the helth of his soule and body"; there was Thomas Hill's "A most briefe and pleasaunt treatyse teachynge how to dress, sowe, and set a garden, gathered out of the principallest authors in this art"; there was Bacon's "Essay on Gardens"; and there was "The Gardener's Labyrinth," by Didymus Mountaine, which last seems to have been chiefly derived from one of the many editions of Hill's book. Borde and Hill were little more than compilers who drew their material from earlier works by Italian writers, and Bacon's " Essay" was merely a gathering of theories set forth with all the charm of a scholarly style. But all these books are interesting, because they provide evidence that the subject with which they deal was one which made an appeal to many readers.

Bacon's theoretical garden inclines decidedly towards what may be called the extreme development of the Renaissance manner. $\mathrm{He}$ accepts, certainly, much of the mediæval tradition, but he prescribes all sorts of additions which are clearly suggested by his sympathy with the importations from Italy-the fountains and statues, the clipped trees, the arcades, and the fantastic ornaments of coloured glass "gilt for the sunne to play upon." In Hill's book, and in "The Gardener's Labyrinth," the bulk of the information offered is openly taken from Roman authorities, whose works are either quoted directly or freely referred to; but, besides, there are some hints given about garden-making, as it was understood at that time, which are not without value to the student of garden history, because they refer to a somewhat less ambitious type of design than Bacon had in mind. Hill and Bacon were both theorists, but the former addressed himself to average people who wanted but a modest pleasure ground, the latter offered advice to the few men who could afford to do things on a large scale.

One famous garden is supposed to have been laid out in accordance with the prescriptions in Bacon's essay-that at Moor Park for the Countess of Bedford. Of this place an account exists written by Sir William Temple, who evidently admired it unreservedly :- "The perfectest figure of a garden I ever saw, either at home or abroad, was that of Moor Park in Hertfordshire. I will describe it for a model to those that meet with such a situation, and are above the vi 


\section{THE HISTORY OF GARDEN-MAKING}

regards of common expense. It lies at the side of a hill, upon which the house stands, but not very steep. The length of the house, where the best rooms and of most use and pleasure are, lies upon the breadth of the garden; the great parlour opens into the midst of a terrace gravel-walk that lies even with it, and which may be about three hundred paces long and broad in proportion; the border set with standard laurels, which have the beauty of orange-trees out of flower and fruit. From this walk are three descents by many stone steps, in the middle and at each end, with a very large parterre. This is divided into quarters by gravel-walks, and adorned with two fountains and eight statues at the several quarters. At the end of the terrace walks are two summer-houses, and the sides of the parterre are ranged with two large cloisters open to the garden. Over these two cloisters are two terraces covered with lead and fenced with balusters; and the passage into these airy walks is out of the two summer-houses at the end of the first terrace walk. The cloister facing the south is covered with vines. From the middle of the parterre is a descent by many steps into the lower garden, which is all fruit-trees, ranged about the several quarters of a wilderness, which is very shady; the walks here are all green, and there is a grotto embellished with figures of shell, rockwork, fountains, and waterworks."

As Sir William Temple can be counted among the advocates of the formal style, his praise of the Moor Park garden as it was when he wrote-the character of the place has since been radically alteredis certainly-significant. The arrangement he describes must have been admirably effective, and excellent both in its stateliness of planning and its richness of detail; and the garden must have provided a quite satisfactory illustration of the Italian manner. How far its beauties can be referred to Bacon's suggestions cannot now be said, but it is quite possible that the real designer was inspired by the theories so pleasantly set forth in the "Essay on Gardens," and that he found in the fancies of a cultivated and intelligent literary man much which was capable of being put into actual practice.

The first books of English writers in which the art of garden designing was treated from the standpoint of personal knowledge appeared early in the seventeenth century. They were by Gervase Markham and William Lawson, both of whom had tested by many years of practical experience the principles which they advocated. Markham, though he wrote for the man of ordinary means rather than for the few wealthy personages, was a strong believer in the need for orderly formality in even the least ambitious garden; and 
the rules he laid down for the planning of both pleasure grounds and herb gardens show how much importance he attached to careful consideration of even the smaller details of the design. He divided his space into squares, each of which was to be surrounded by a path and subdivided into four quarters by other paths, and at the intersection of these paths there was to be placed a sundial, a pyramid, a fountain, or some other architectural feature. If the squares could be arranged on different levels, flights of steps, "staires of state," were to be built connecting them. He retained the high wall, or quickset hedge, as a surrounding to the entire garden, in this adhering to the mediæval fashion; and he also retained that other mediæval feature, the knot or border planted with flowers in an elaborately formal pattern. These knots were to occupy each of the subdivisions of the square.

Lawson, in the same way, advocated regularity, and his books, "The Countrie Housewife's Garden" and "A New Orchard and Garden," recognise formality as a matter of course. He, too, directs that the garden should be a square enclosed within a wall, and that it should be ornamented with knots; and, like Markham, he expects the same care to be bestowed upon the planning of the part intended for use as upon that intended for show and enjoyment. His idea of an orchard is a place with walks and seats, beds of flowers, clipped trees, mazes, and other ornamentations; and the kitchen garden is to be made gay with flowers-nature's charm is not to be sacrificed for the sake of mere utilitarianism.

Indeed, the love of nature is very apparent in Lawson's way of treating his subject; he was an idealist, although the purpose of his books was deliberately practical, and the garden he imagined was a place where all the senses could be gratified. He expresses this idea admirably in such words as these:- "What can your eye desire to see, your eare to heare, your mouth to taste, or your nose to smell, that is not to be had in an orchard with abundance and beauty? What more delightsome than an infinite varietie of sweet-smelling flowers? decking with sundrye colours the greene mantle of the earth, the universal mother of us all, so by them bespotted, so dyed, that all the world cannot sample them, and wherein it is more fit to admire the Dyer than imitate his workmanship, colouring not only the earth but decking the ayre, and sweetening every breath and spirit.

"The rose red, damaske, velvet, and double, double province rose, the sweet muske rose double and single, the double and single white rose, the faire and sweet-scenting woodbind double and single; viii 


\section{THE HISTORY OF GARDEN-MAKING}

purple cowslips and double cowslips, primrose double and single, the violet nothing behind the best for smelling sweetly, and a thousand more will provoke your contente, and all these by the skill of your Gardener so comely and orderly placed in your borders and squares."

All this illustrates the spirit in which the art of gardening was carried on by the men who were to a large extent free from the Italian influence, or who had the acuteness to perceive how the earlier traditions could be used as a kind of stock upon which the Italian methods could be grafted; and such books as Lawson's are the more interesting because they were written by a gardener who, as he says in the Preface to his "New Garden and Orchard," was able to draw upon the knowledge he had acquired by "the labours of forty-eight years." In working out the sequence of events in the history of garden-making, the writings of Markham and Lawson are of special value, for they not only throw light upon the way in which the surroundings of most country houses of any pretension were treated at the end of the sixteenth century, and for a large part of the seventeenth, but they also provide many hints of what must have been the ordinary practice at an earlier period before the novel artificialities of the Renaissance manner began to unsettle the beliefs based upon the mediæval tradition. It would certainly appear that even at the beginning of the seventeenth century such gardens as those at the Palaces of Nonsuch and Hampton Court, or the "perfectest figure of a garden" at Moor Park, were as exceptional in style as they were in extent, and represented little enough the general practice.

Of seventeenth-century gardening in the traditional manner, but on a large scale, probably no better example could be quoted than that at Wilton. For the laying out of this garden the Earl of Pembroke secured the services of the German architect, Isaac de Caux, of whose work an ample record exists, for he issued a series of engravings of the place, with a detailed explanation of its particular characteristics:- "This Garden, within the enclosure of the new wall, is a thowsand foote long and about foure hundred in breadthe, divided in its length into three long squares or parallelograms, the first of which divisions next the building heth foure Platts, embroydered; in the midst of which are foure fountaynes with statues of marble in their midle, and on the sides of those Platts are the Platts of flowers, and beyond them is the little Terrass rased for the more advantage of beholding those Platts, this for the first division. In the second are two Groves or woods all with divers walkes, and 
through those Groves passeth the river Nader having of breadth in this place 44 foote, upon which is built the bridge of the breadth of the greate walke. In the midst of the aforesayd Groves are two great statues of white marble, of eight foote high, the one of Bacchus and the other of Flora, and on the sides ranging with the Platts of flowers are two covered Arbors of 300 foote long and diverse allies. Att the beginning of the third and last division are, on either side of the great walke, two Ponds with Fountaynes and two Collumnes in the midle, casting water all their height which causeth the moveing and turning of two crownes att the top of the same, and beyond is a Compartment of greene with diverse walkes planted with cherrie trees and in the midle is the Great Oval with the Gladiator of brass; the most famous Statue of all that antiquity hath left. On the sydes of this compartiment and answering the Platts of flowers and long arbours are three arbours of either side with twining Galleryes communicating themselves one into another. Att the end of the greate walke is a Portico of stone cutt and adorned with Pilasters and Nyches, within which are 4 figures of white marble of 5 foote high. Of either side of the sayd portico is an assent leading up to the terrasse, upon the steps whereof instead of Ballasters are sea monsters casting water from one and the other from the top to the bottome, and above the sayd portico is a great reserve of water for the grotto."

But within a very few years an extensive revision of the work done by de Caux was carried out at Wilton. A new designer appeared, Inigo Jones, who had studied the neo-classic style in Italy, and had given special attention to the productions of Palladio. The knowledge he had acquired abroad of the Renaissance methods he turned to such excellent account when he came home that he was able to set a fashion which, if not actually new, was at all events sufficiently novel to become widely popular. He gave a great impetus to the Italian revival, which had made a beginning in England a century before, and he exercised a very real influence upon house and garden architecture. The modifications and additions for which he was responsible at Wilton-among them the beautifully proportioned Palladian bridge over the river-were typical of the changes which he and his followers made in many other gardens, and had no little significance as evidences of the alterations which were being brought about in the public taste by the introduction of a new architectural sentiment. The Italian villa surrounded by appropriate gardens became quite common in this country, and many of the examples of the earlier garden-making which had been preserved 
through the sixteenth century were now destroyed or drastically remodelled.

However, the Inigo Jones fashion was not destined to be long-lived, for the disturbances of the Civil War put a stop for a while to the cultivation of the arts, and the dealings of the Puritans with the pleasure grounds of the great houses were directed rather to the effacement of existing beauties than to the development of new and attractive features. What John Evelyn wrote about the condition of the gardens of Nonsuch Palace in the reign of Charles II. "There stand in the garden two handsome stone pyramids, and the avenue planted with rowes of faire elmes; but the rest of these goodly trees, both of this and Worcester Park adjoyning, were felled by those destructive and avaricious rebels in the late war, which defaced one of the stateliest seats his Majesty had"-could have been written about many other places which had previously been worthy to rank as notable illustrations of the gardener's craft. It is no doubt true that the Puritans have been blamed unjustly for many sins against good taste which were committed by other people, but they certainly diminished rather than increased the number of gardens which deserve to be included in the list of historical examples.

The accession of Charles II. gave the garden designers once more opportunities of distinguishing themselves, but it did not quite put things back to where they were before the Civil War. Instead, it brought into this country another fashion derived not from Italy, like that for which Inigo Jones was responsible, but from France, where very remarkable advances had been made in the art of garden planning. The chief of the French exponents of the art was Le Nôtre, a man of brilliant ability and judicious originality, and a designer who was able to build on what had gone before a style definitely personal. His conceptions were on the largest possible scale, and there was a sumptuous vastness in his work which no one else had ever attempted. The gardens he planned did not cover merely a few acres, they occupied enormous spaces of ground, and, when possible, were combined with avenues which extended often for miles beyond the boundaries of the garden proper.

Whether Le Nôtre actually executed any work in England is disputed, but he is reputed to have laid out gardens at Hampton Court and Greenwich, as well as that which at one time surrounded St. James's Palace. If, however, there is some doubt whether or not he visited this country, there can be no question about the extent of the influence he exercised over some English gardeners who had to do 
with places that called for treatment on a large scale. His system of arranging avenues radiating from a centre, his use of broad and dignified terraces and formal lakes, were frankly adopted in England, and in what remains of the garden work done at this period the signs of his inspiration are not to be mistaken.

As an example of the results arrived at by following Le Nôtre's methods, the laying-out of the park and gardens at Badminton can be particularly noted. A description of this place, as it was about the end of the seventeenth century, is given in the admirable book on "The Formal Garden in England," by Mr. Reginald Blomfield and Mr. F. Inigo Thomas:- "The approach to the house was formed by a triple avenue, the centre avenue 200 feet wide, the two side avenues 80 feet wide. The entrance gates to this avenue were placed in the centre of a great semicircular wall. The distance from this gateway to the house was $2 \frac{1}{2}$ miles. After passing through two more gateways, the avenue opened on to a great oblong open space forming part of the deer park, with avenues on either side, and the entrance gate to the forecourt of the house opposite the end of the main avenue. A broad gravelled path, with grass plots and fountains on either side, led from the entrance gate of the forecourt to a flight of four steps leading to the pavement in front of the house. To the right hand was the base court, with stables and outhouses; at the back of the house the kitchen and fruit gardens and the pigeon-house. To the left of the house and forecourt were the bowling green and pleasure gardens, with the grove beyond. The latter was divided into four plots, with four-way paths and a circular space and fountain in the centre. Each of the plots was planted with close-growing trees laid out as mazes, and trimmed close and square for a height apparently of some I 5 to 20 feet from the ground. Opposite the centre alley was a semicircular bay divided into quadrants, each quadrant with a basin and fountain, and great square hedges trimmed to the same height as the rest of the grove. The whole of these immense gardens were walled in, with the exception of a fence round the grove. Wide gates were set at the ends of all the main paths, and from these, as points of departure, avenues were laid out in straight lines, radiating and intersecting each other in all directions."

Some of these avenues at Badminton are said to have been as much as six or seven miles long, so that it can be clearly seen that in laying out such a place as this the designer responsible must have been capable of imagining large effects, and must have understood how to plan vast arrangements in which the actual walled garden xii 


\section{THE HISTORY OF GARDEN-MAKING}

was but the centre and starting-point of a great decorative scheme. Le Nôtre undoubtedly induced English gardeners to enlarge their ideas of garden-making, and taught them some things which they did not know before; though naturally they had not many opportunities such as were offered at Badminton of showing how ready they were to accept his principles of design.

As a matter of fact the great gardens in the French fashion were not numerous, and the ordinary country gentleman continued during the seventeenth century, and part of the eighteenth, to use most of the earlier devices and most of the traditional formalities. He did his laying-out, perhaps, on a somewhat more generous scale and with a view to more sumptuous effects; he adopted, not always discreetly, some of the novelties of the French method; but if occasionally he inclined rather too readily towards fountains and statues and pretentious avenues, he more often remained faithful to the knots and wildernesses, the rectangular divisions, the evenlyspaced paths, and the architectural embellishments which had pleased his ancestors. The ideas imported from abroad had not destroyed the influence of such writers as Gervase Markham, and even in such a book as the "Systema Horticulturæ, or Art of Gardening," written by John Worlidge, and published in 1677 , when the Le Nôtre fashion was in the ascendant, the formal manner sanctioned by long custom is advocated with scarcely any alteration. In the reigns of William and Mary and Anne some modifications were introduced into the art of gardening, but they changed details rather than main principles. From Holland there came with William and Mary that variation of the Renaissance manner which is known as Dutch gardening, a very evident descent from the expansiveness of Le Notre, and in many respects a parody of the Italian work. The Dutch love of quaintness had brought about an exaggeration of the ancient device of clipping trees into purely artificial forms, and as a result of this exaggeration a practice which had been sanctified by centuries of use in England and abroad was reduced to an absurdity. The topiary work which was executed in English gardens in the earlier years of the eighteenth century was too often without dignity or taste-merely extravagant and ridiculous. It showed the degeneration of the gardener's art, and marked a definite decay in the feeling for restful simplicity which had governed the laying-out of so many of the older places.

But this degenerate art did not lack appreciation : there was a wide demand for fantastic additions to the garden, and this demand was supplied by many firms, like that of London and Wise at Chelsea, xiii 
which did their utmost to satisfy the new taste. The clipped trees, which had been previously not without a certain architectural appropriateness, became utterly unnatural and unmeaning incongruities, which did not fit in well with any properly considered scheme of design. They introduced a touch of comicality into formal gardening, and brought upon it a measure of discredit.

There was, indeed, a change coming over the spirit of the gardener's art, and the misuse of topiary work was at the same time one of the effects and one of the causes of this change. The influence of Le Nôtre had done something to unsettle English gardeners, inasmuch as it had induced many of them to extend their boundaries and to consider the possibility of going outside the four walls within which the older gardens had been confined. They began to have ambitions to direct and discipline nature, and out of these ambitions soon grew the idea that what their predecessors had done was too much according to rule, and therefore too narrowly conventional to be accepted by reformers who aspired to solve nature's secrets. As a protest, conscious or unconscious, against these new notions, the followers of the earlier school were led into topiary extravagances, and thereby gave themselves over to the enemy. The advocates of what was called progress were provided with many a text for attacks upon the principles of design which they were trying to destroy by the men who were theoretically most anxious to see these principles strictly upheld.

Many able writers, Pope and Addison at their head, threw themselves into the struggle between the opposing schools of gardening, and for the most part advocated the ideas of the new school. An article which appeared in "The Guardian" in 1712 is worth quoting as an example of the support given to the believers in change:- "How contrary to simplicity is the modern practice of gardening! We seem to make it our study to recede from nature, not only in the various tonsure of greens into the most regular and formal shapes, but even in monstrous attempts beyond the reach of art itself; we run into sculpture, and are yet better pleased to have our trees in the most awkward figures of men and animals than in the most regular of their own. A citizen is no sooner proprietor of a couple of yews but he entertains thoughts of erecting them into giants like those at Guildhall. I know an eminent cook who beautified his country seat with a coronation dinner in greens, where you see the champion flourishing on horseback at one end of the table, and the queen in perpetual youth at the other.

"For the benefit of all my loving countrymen of this curious taste, xiv 


\section{THE HISTORY OF GARDEN-MAKING}

I shall here publish a catalogue of greens to be disposed of by an eminent town gardener, who has lately applied to me on this head. My correspondent is arrived at such perfection that he cuts family pieces of men, women, or children. Any ladies that please may have their own effigies in myrtle, or their husbands in hornbeam. I shall proceed to his catalogue as he sent it for my recommendation.

"Adam and Eve in yew ; Adam a little shattered by the fall of the tree of knowledge in the great storm; Eve and the Serpent very flourishing; the Tower of Babel not yet finished; St. George in box, his arm scarce long enough, but will be in condition to strike the dragon by next April; a Queen Elizabeth in phylyroea, a little inclining to the green-sickness, but of full growth ; an old maid-ofhonour in wormwood; divers eminent poets in bays, somewhat blighted, to be disposed of a pennyworth; a quickset hog shot up into a porcupine by its being forgot a week in rainy weather."

Against attacks such as this the old formality was unable to make any effective resistance, and gradually, but none the less surely, it had to give way to the new fashion. It died hard, and throughout the eighteenth century it continued to find adherents, but in steadily diminishing numbers. Meanwhile the men of the landscape gardening school were busy in all directions obliterating the work which had survived from past generations and creating gardens which, with all their professed naturalism, were in a different way just as formal as anything that had existed before; only the formality was less honest and less logical, and hardly more in sympathy with nature's real spirit.

What were the methods employed can be judged from the account given by Horace Walpole :- "No succeeding generation in an opulent and luxurious country contents itself with the perfection established by its ancestors; more perfect perfection was still sought, and improvements had gone on till London and Wise had stocked all our gardens with giants, animals, monsters, coats-of-arms, and mottoes in yew, box and holly. Bridgman, the next fashionable designer of gardens, was far more chaste; he banished verdant sculpture, and did not even revert to the square precision of the foregoing age. He enlarged his plans, disdaining to make every division tally to its opposite; and though he still adhered much to straight walks with high clipped hedges, they were only his great lines; the rest he diversified with wilderness, and with loose groves of oak, though still within surrounding hedges. As his reformation gained footing, he ventured to introduce cultivated fields and even 
morsels of forest appearance by the sides of those endless and tiresome walks.

"But the capital stroke, the leading step to all that followed, was the destruction of walls for boundaries and the invention of fosses: an attempt then deemed so astonishing that the common people called them ' $\mathrm{Ha}$ ! ha's !' to express their surprise at finding a sudden and unperceived check to their walk. No sooner was this simple enchantment made than levelling, mowing, and rolling followed. The contiguous ground of the park without the sunk fence was to be harmonised with the lawn within; and the garden in its turn was to be set free from its prim regularity, that it might assort with the wilder country without. At that moment appeared Kent, painter enough to taste the charms of landscape, bold and opinionative enough to dare and to dictate, and born with a genius to strike out a great system from the twilight of imperfect essays."

The men referred to in this extract, Bridgman and Kent, played a considerable part in the development of the new fashion. Bridgman was gardener to George I., and was entrusted with the laying-out of several important places, among them Stowe, in Buckinghamshire. His methods were not excessively advanced, for he had some respect for the old style and did not try to break away too abruptly from everything which had been accepted in the past. He abandoned, however, the more extravagant form of tree-clipping, and therefore must be counted among the reformers who desired to make a practical protest against the abuse of a time-honoured practice; and by his disinclination to "revert to the square precision of the foregoing age," at least prepared the way for the great changes which were imminent.

William Kent was much more ambitious and broke far more definitely with the past. He was in many ways a remarkable man, following several professions, though in none of them did he rise to real eminence. In his youth he was apprenticed to a coach-builder, but soon after the beginning of the eighteenth century he came from Yorkshire, where he was born, to London to follow the profession of a portrait and historical painter. There he found many patrons and achieved so large a measure of success, that in 1710 he was able to go to Italy to study. In I 79 he returned to England with Lord Burlington, in whose house he resided till his death, in 1748 , and by whose influence he obtained several court appointments, and a considerable amount of private work. As an architect he was not unsuccessful, for in this branch of art he showed more real capacity xvi 


\section{THE HISTORY OF GARDEN-MAKING}

than appears in his productions as a painter and sculptor, and some of the buildings he designed are by no means unworthy of commendation.

But in his garden work his point of view was that of the painter rather than the architect. He tried to produce pictorial effects, and to re-arrange nature on the lines of the pictures by the painters of classical landscape, whose canvases he had presumably learned to admire while he was abroad. The principles he affected are summed up by Horace Walpole :- "Selecting favourite objects, and veiling deformities by screens of plantations, he realised the composition of the greatest masters in painting. The living landscape was chastened and polished, not transformed." Walpole was of the naturalistic faction, so his praise was not without bias, and his estimate of Kent's capacities deserves to be to some extent discounted. Present-day opinion would hardly endorse so readily this chastening and polishing process, or count it as the evident invention of a brilliant genius.

For what Kent really did was to substitute one kind of formality for another. He threw over topiary work entirely, he avoided regularity of line, and, like Bridgman, would have nothing to do with "square precision"; but, nevertheless, he chastened Nature with undue severity, and dressed her in a kind of penitential sheet which cloaked most of her true beauties. His " great system" was a piece of artificiality, and was, perhaps, best described by Scott, who said of him, that " his style is not simplicity, but affectation labouring to seem simple." His planted pictures lacked breadth and distinction, and instead of the dignified quaintness of the old arrangements, had a quite unnecessary restlessness and want of harmony. $\mathrm{He}$ committed many absurdities too, sticking up dead trees deliberately to give a touch of realism to the little patches of sham forest which he designed-a trick which was adopted by the landscape painters of the conventional school-and building ruins of Gothic churches or Grecian temples to increase what he conceived to be the picturesqueness of his gardens.

It must be admitted, however, that his labours were much approved by his contemporaries. Walpole was not the only writer who hailed him as a genius; there was a chorus of praise headed by Mason, the poet, who exhausted the resources of the English language in eulogy of Kent and his methods. During the first half of the eighteenth century a spurious nature-worship had become fashionable-spurious because it was based not upon true sympathy with nature's inherent charm, but upon a fancy for those scenic landscape compositions in which such painters as Claude or Poussin travestied reality. How 
little sense there was in the adulation of landscape gardening, as it was then understood, can be judged from a sentence of Walpole's, that "Kent leapt the fence and saw that all nature was a garden."

Yet Kent, despite his destruction of many interesting examples of the work of his predecessors, and despite, also, the unsoundness of his artistic principle, must be ranked as a most conservative person and as a most enlightened designer beside the designers who succeeded him. The art of gardening fell into the hands of such men as Martin Brown-nicknamed "Capability" Brown-Humphrey Repton, Wright, and Thomas Wheatly, who was responsible for the up-rooting of what was left of the formal gardens at Nonsuch Palace; and all of these had even less sympathy than Kent with the old ideas and less capacity to conceive new ones. All they could do was to go on obliterating the relics of the past and wrecking everything which could claim consideration on the score of respectable antiquity until they had provided ample justification for the plaintive lament of Sir William Chambers, that "Our virtuosi have scarcely left an acre of shade, or three trees growing in a line, from the Land's End to the Tweed."

The most notable of this group of gardeners was "Capability" Brown. He was not, like Kent, a trained artist who worked mistakenly under the impression that he was following strict æsthetic rules, he was not even a man of culture or educated conviction. Ignorant and untrained, he was by interest advanced from the charge of Lord Cobham's kitchen garden to be gardener at Hampton Court and Windsor, and on the strength of this appointment he was able to pose as an authority on garden designing in the new style. His services were widely in request; everyone who was bitten with the craze for improvement came to him for advice and assistance, and he had endless opportunities of putting into practice his crude theories of naturalistic design. As a consequence he did an incalculable amount of harm, destroying right and left what remained of the old pleasure grounds, and replacing them by arrangements of his own devising.

As he knew practically nothing of his subject, and as, moreover, he prided himself on knowing nothing, he adopted a set formula which expressed his conception of nature, and to this formula he almost always adhered. His stock materials were a belt of plantation round the space he had to lay out, a few clumps of trees "playfully," as he called it, dotted about the ground, and a lake or stretch of river brought in, as often as not, with hardly any reference to its surroundings. That such narrow conventionality should ever have xviii 
been accepted as in accordance with the spirit of nature seems to us now almost incredible, and it is difficult to understand how anyone of intelligence could have believed that this sort of empty formality was worthy to be described as landscape gardening. But though Brown's methods were ridiculed by some people and but faintly praised by others-Daines Barrington, for instance, said of him that "he had undoubtedly great merit in laying out pleasure grounds; but I conceive that in some of his plans I see more traces of the kitchen gardener of old Stowe than of Poussin or Claude Lorraine" - the fact remains that the royal gardener was for many years a kind of dictator in matters of taste, and at his death, in I 783 , left a large fortune, the accumulation of the fees paid to him by grateful clients.

The other members of the group were not more scrupulous and hardly more intelligent; they rivalled "Capability" Brown in destructiveness, and they had no better understanding of the subtleties of the art which they misused. But so strong was the influence of the fashion which dominated gardening during the latter half of the eighteenth century that these men were able to do anything they pleased, and were given an absolutely free hand by the people who employed them. Wheatly wrote a book, "Observations on Modern Gardening," which, with Walpole's "Essay on Modern Gardening," published a few years later, became the accepted authority on the new type of design not only in England, but on the Continent as well. The rage for destruction spread widely, indeed, and the English influence was powerful enough abroad to produce effects which seem now scarcely defensible. We have at the present time a truer appreciation of the value of relics from the past than was common among the people of the eighteenth century, and we can sincerely regret the zeal of the reformers who were so needlessly anxious to be modern at all costs.

But the movement in the direction of landscape gardening, as opposed to the trim formality of the earlier school, was too strong to be stemmed by the protests of the few thinkers who realised what was being lost. The formal garden had become discredited, partly because its decorative characteristics had been allowed to get beyond reasonable bounds into sheer extravagance, and partly because its particular features had grown too familiar to the public, and had in consequence lost the charm of freshness. Its associations were forgotten, and its claims to consideration were overlooked. Hardly anyone paused to think whether, after all, the price that was being paid for novelty was not too high. Yet in the wilderness of 
landscape gardening a voice was to be heard here and there lamenting the excesses of the new school, and begging for less haste and less reckless concessions to fashion. Sir Uvedale Price wrote a treatise on "The Decorations near the House," in which he tells the story of his dealings with his own old garden, and grieves over the changes he had brought about by re-arranging it on the new lines. Sir Walter Scott in 1827 championed the cause of the formal garden against the inventions of the landscape gardener, and pointed his argument by reference to a place in Scotland which, once delightful in its antique quaintness, had become, when remodelled, "as common and vulgar as may be"; and other writers followed from time to time on the same lines.

It was not, however, till the latter half of the nineteenth century that any consistent effort was made to revive the old type of garden design. Within the last fifty years there has sprung up a quite considerable school of garden-makers, including many architects of distinction, who treat the earlier traditions with intelligence and discretion, and in applying them show a large measure of originality. The work of these men is something more than a mere reconstruction of what was customary two or three hundred years ago, and is free from those fantastic excesses which brought the formal garden into disrepute. It is frankly architectural in the sense that it is planned with due regard for precision of line and balance of masses; and the effects at which it aims depend not upon happy accidents more or less shrewdly led up to, but upon well-judged construction which prepares exactly for what is to come. The main purpose of it all is to reintroduce into modern gardens the quiet dignity and the sober richness of the seventeenth century design, without closing the way to those ingenious designers who can give a new meaning and an increased significance to their combinations of the materials used by their predecessors.

At the same time this revival of formal planning is not by any means affecting the popularity of landscape gardening. The two types of work flourish now side by side, and as the modern formality is freer and less restricted than the old, so the modern landscape design is less conventional and narrow in application than that of "Capability" Brown and his followers. The landscape gardeners of to-day are not afflicted with the delusion that they can or should model themselves upon popular painters, and plant compositions which will reproduce pictures shown at the National Gallery or the Academy. They do not merely refuse to draw inspiration from the canvases of Claude or Poussin, they seek suggestions from nature $\mathrm{xx}$ 


\section{THE HISTORY OF GARDEN-MAKING}

direct, and try to keep in their work something of her spontaneity and charming irregularity. In both types of garden-making there is evidence that the lessons of the past have been thoughtfully studied, and that the need for reticence, for avoidance of any extravagance of manner, is generally appreciated.

As a proof of the increase of the popular interest in gardening today, it is sufficient to point to the great growth which has taken place in the literature on the subject. In the many periodicals devoted to the horticultural side of garden work, artistic questions receive much attention, and articles discussing these questions are plentiful enough in the magazines which deal with topics attractive to the general reader. But in recent years there have also appeared several important books like "The Formal Garden in England," by Mr. Reginald Blomfield and Mr. F. Inigo Thomas, which has been already referred to, and "The Art and Craft of Garden Making," by Mr. Thomas H. Mawson, books from which the student of the art can obtain much useful information about what he should do and many valuable hints as to what he should avoid. Indeed, a quite considerable library on gardening is now at the disposal of everyone whose love of nature is great enough to make him anxious to use in the right way the treasures she puts within his reach. The reign of the faddists may fairly be said to be over at last, and the different schools of gardeners are now wisely tolerant of one another. There is ample room for individual effort, so we may fairly hope to see in the near future a strong and healthy development of the many possibilities of an art which has the greatest imaginable claims to serious encouragement. 


\section{THE PRINCIPLES OF GARDEN- MAKING.}

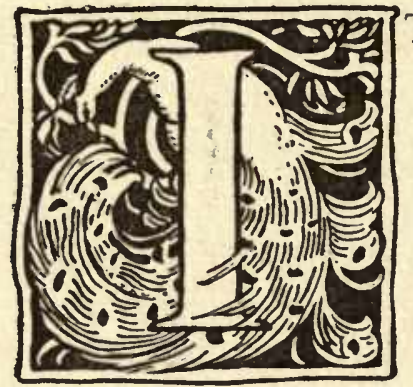

$T$ may fairly be laid down as the first essential in the planning of a garden that there should be some sort of direct connection between the kind of surrounding which is given to a house and the architectural character of the house itself. To treat the garden as an entirely separate affair, unrelated in any way to the building to which it is intended to serve as a setting, is neither judicious nor artistically expedient. Such a separation would inevitably produce an unpleasant effect, and would suggest a lack of intelligence on the part of the garden designer. In a rightly conceived plan it is not only the outlook on to the garden from the house that is taken into account; at least as much consideration is given to the views which are to be obtained in different directions from the garden itself, and obviously the house must be reckoned as a vitally important feature in any scheme which is devised to make these views fully effective. A thatched cottage surrounded by an elaborate Italian garden with terraces, statues, and fountains, would look absurdly out of place, and there would be no less incongruity in putting a palace in the middle of a wild and uncultivated field; either arrangement would be opposed to both good taste and common sense. But if the garden is made, as it should be, an appropriate adjunct to the house, and is designed in a style that is consistent with the architectural characteristics of the building, the result is agreeably harmonious, and has that air of completeness which makes convincing all-round artistic achievement.

If the importance of this connection is recognised by the garden designer he can reasonably be allowed a free hand in the carrying out of the work entrusted to him, for he will have a sufficiently sound knowledge of his subject to prevent him from lapsing into any fanatical preference for one particular type of garden-making. Much of the harm done in the past by the men who destroyed the work of the earlier gardeners, and replaced it with what they imagined to be modern and up-to-date, was due to the fact that these iconoclasts did not realise that there was any necessity to bring the house and garden into strict relation. They adopted a fashion merely, a fashion which was supposed to be capable of xxii 
general application, and they could not see that there were many occasions when adherence to a set formula was not only inexpedient but actually at variance with sound artistic principles. To understand when the old work was perfectly fulfilling its decorative function, and was worthy of preservation because it filled its place admirably, was quite beyond them ; they had chosen a new convention, and everything which did not come within the limits of this convention they condemned as unfit to exist.

Few people to-day would be disposed to question the absurdity of narrowing down the practice of an adaptable and expressive art in a manner so utterly unreasonable. We can see now that there is a place for both the formal garden and for the efforts of the landscape gardener, and that each, under the proper conditions, is worthy of attention. Conformity to a dominating convention is neither expected nor tolerated; indeed, the more frankly personal the designer's methods the more likely is he to gain appreciation, and the more plainly he shows that he has profited by the lessons and the warnings of the past the better are his chances of success in his profession.

Concerning the modern treatment of the formal garden it can be safely said that much good has resulted from the entry of the architect into the ranks of the garden designers. To secure the right kind of formality in the laying out of the surroundings of any house the whole thing must be planned with due regard for architectural effect. In the stricter type of formal garden, enclosed frankly and definitely within boundary walls, there can be nothing left to happy accidents and there must be no mistakes for nature to correct. Every line, every mass, must be rightly placed and properly accounted for, every detail must be in obvious relation to the general scheme of which it forms an essential part. And the balancing and relating of lines, masses, and accessory details must be carried out with just the same care and in just the same spirit that are required in the construction of a judiciously elaborated piece of architecture.

It must also be remembered that the garden laid out on such precisely architectural lines is intended to be, as it were, a frame to the house, to cut it off from the country beyond and to enhance its charm by a particular setting. Therefore to allow the garden to gradually merge in the more distant landscape is inexpedient, for by such a device much of the meaning and strength of a formal design must necessarily be lost. In the framing of a picture what is aimed at is to provide a surrounding which will be in keeping $c$ xxiii 
with the character of the picture itself, but will serve especially as a neutral zone to separate the painting sharply from the wall on which it hangs; any idea of gradually connecting the picture with the wall-paper by means of the frame would be voted absurd, and would be treated as a fad unworthy to be taken seriously. The real purpose of the formal garden is to create this kind of neutral zone round the house, and therefore its boundaries must be as distinct as those of the picture frame.

Yet many of the earlier designers seem to have been unable to appreciate the artistic significance of this limitation. After the movement began in the direction of landscape gardening the men who still professed to support the formal tradition made a sort of compromise, and while they kept the formality immediately round the house they slid by gradations into wild nature as they got further away. Sir Uvedale Price, for instance, recommended a division into compartments. A formal garden first, a landscape garden next, and a park beyond allowed to grow as it pleased; and much the same arrangement was advocated by Repton, the successor and follower of "Capability" Brown. Like all compromises, these attempts to combine divergent styles of gardening in a limited space could hardly fail to be anything but unsatisfactory; such a collection of examples of different schools of garden design could be successfully made only in some large place where there would be room to treat each section as an entirely separate specimen of technical practice.

Certainly it is better, in the ordinary way, to make the formal garden as absolutely as possible a distinct creation, and to relate it clearly to the house rather than to attempt futilely to bring it even remotely into touch with untutored nature. There is, of course, no need to carry formality into excess or extravagance, or to re-introduce any of those topiary absurdities which in the past brought discredit upon this form of garden-making; and on the whole there is little danger of any such departures from good taste while the designing of the formal garden remains in the hands of men who are properly conscious of the value of architectural refinement. In our modern efforts to revive an art which, partly by its own fault and partly by misuse, has fallen into a bad condition we can base our practice upon what is best in the ancient tradition, and can refer to well-established records for guidance as to what we should avoid. We have a clearer view of what is desirable than the men who, a couple of centuries ago, mistook a mere departure from custom for judicious and progressive originality; xxiv 
and by the aid of this clearer view we ought to make the English formal garden once again a really living thing.

At the same time it would be very undesirable to have in existence again a formal convention: fashion has done so much harm to the gardener's art that the avoidance of stereotyped methods of practice, which are followed simply because they chance to be popular, is urgently necessary. The formal garden has its place in domestic decoration, and a place that is important and definite enough ; but, as has been already said, there is ample room for the landscape garden also. But the modern landscape garden must not be a studied and narrow preconception like Kent's planted pictures or Brown's belt, clump, and lake combinations. The landscape gardener must be a student of nature at first hand, and must be fitted by the thoroughness of his study to adapt realities to the purposes of his design. For him, too, there are many warnings in the mistakes of his predecessors; he can see plainly enough, if he chooses, how ignorantly and arrogantly men of Brown's type set about the rearrangement of nature to suit themselves, and how deficient they were in that refinement of taste which alone would have justified their pretensions.

But he can obtain also many hints as to the direction in which his own development should tend from the precepts of some of the designers who were in the thick of the conflict which resulted in the destruction of the formal garden. Repton, though he committed himself in his work on "Landscape Gardening" to such an absurd statement as this:- "The motley appearance of red bricks with white stone, by breaking the unity of effect, will often destroy the magnificence of the most splendid compositions," and advocated unity of effect produced by the use of stucco or paint, was a garden designer of more intelligence than most of his immediate contemporaries. Some of his suggestions are quite worth rememberingfor instance, "There is no error more prevalent in modern gardening, or more frequently carried to excess, than taking away hedges to unite many small fields into one extensive and naked lawn before plantations are made to give it the appearance of a park; and where ground is subdivided by sunk fences imaginary freedom is purchased at the expense of actual confinement," or, "the boldness and nakedness round the house is part of the same mistaken system of concealing fences to gain extent. A palace, or even an elegant villa, in a grass field, appears to me incongruous."

In other comments on the fashion of his time he shows a useful degree of independence:- "The plantation surrounding a place, 
called a belt, I have never advised; nor have I ever willingly marked a drive, or walk, completely round the verge of a park, except in small villas, where a dry path round a person's own field is always more interesting than any other walk." "Small plantations of trees, surrounded by a fence, are the best expedients to form groups, because trees planted singly seldom grow well. Neglect of thinning and removing the fence has produced that ugly deformity called a clump." "Water on an eminence or on the side of a hill is among the most common errors of Mr. Brown's followers. In numerous instances I have been allowed to remove such pieces of water from the hills to the valleys, but in many my advice has not prevailed."

These remarks have an interest not only because they mark his disapproval of the foolish practices which were in vogue when he lived, but also because they point the absurdity of certain crude methods of landscape gardening which are even now not wholly extinct. There is one more of his precepts which deserves to be quoted, on account of the warning it gives against shallow artificiality :- "Deception may be allowable in imitating the works of nature. Thus, artificial rivers, lakes, and rock scenery can only be * great by deception, and the mind acquiesces in the fraud after it is detected, but in the works of art every trick ought to be avoided. Sham churches, sham ruins, sham bridges, and everything which appears what it is not, disgusts when the trick is discovered." This is frankly a plea for honesty of design, a plea in which there is both common sense and a good measure of artistic discretion. It is set down with something of the same spirit that actuated William Morris when he wrote, "Large or small, the garden should look orderly and rich. It should be well fenced from the outer world. It should by no means imitate the wilfulness or the wildness of nature, but should look like a thing never seen except near the house," though clearly Repton was prepared to go to far greater length in the direction of deceptive imitation of nature than Morris would have considered allowable.

The landscape gardening of the present day is certainly managed by the better class of designers with more taste and with more understanding of its wide possibilities than was shown by most of the eighteenth-century gardeners. We recognise that an artificial piece of landscape can be made to look "orderly and rich," and that even if it is not quite like "a thing never seen except near the house," it can be carried out with something of the studious exactness which the formal garden demands. Much care is taken now to retain the characteristic features of the piece of ground xxvi 
that has to be dealt with, and to make these features the foundation upon which the general planning of the whole garden depends. The principle which governs the best modern work is that laid down by J. D. Sedding:- " The gardener's first duty in laying out the grounds is to study the site, and not only that part of it upon which the house stands, but the whole site, its aspect, character, soil, contour, sectional lines, trees, etc. Common sense, economy, nature, art, alike dictate this. There is an individual character to every plot of land as to every human face, and that man is unwise who, to suit preferences for any given style of garden, or with a view of copying a design from another place, will ignore the characteristics of the site at his disposal."

When this sound principle is observed in garden-making the gardener's practice comes much closer to that of the landscape painter than did the pedantic imitation of pictures which was affected by men like Kent. The preliminary study of the site is like the consideration which the painter gives to the subject which he has chosen and proposes to realise pictorially. Before he sets upon his canvas the piece of nature which is before him he examines it in every part to see which lines he will have to modify, which details to omit or accentuate, and which of the salient masses he must make the main fact in his composition, so as to give the fullest possible suggestion of the particular cliaracter and interest which the subject possesses. The sincere garden designer, in the same way, takes pains to see where and how the ground he has to lay out must be treated so as to make the most cf what beauties it has by nature, and decides what must be added ard what removed, what features must be given more prominence and what must be rendered less conspicuous to perfect the landscape which already exists. His function is a delicate one to fulfil, for he must neither be too literal nor, on the other hand, too much disposed to apply to nature that chastening process in which the early gardeners believed. In a word, he must be an artist, and his artistic sense must be thoroughly trained and absolutely under control.

If landscape gardening is practised in this spirit and by men of this type, it is indisputably worthy to rank beside the best productions of the designer of formal gardens. The primary principle, that the garden must be in exact relation to the house which it surrounds, must, however, not be forgotten, and on many occasions the attempt to imitate nature's freedom and careless charm must be abandoned for frank formality and architectural severity. The artist in gardenmaking should certainly cultivate his selective sense, and should in xxvii 
the work he carries out be quite prepared to be guided by circumstances. The house is his one immutable fact, from which all that he proposes to do must start; his study of the site is next in importance, and in this study it is well that he should not forget that the character of the site can be equally well preserved whether it is a formal or a landscape garden that he lays out upon it. The one thing that is at all costs to be avoided is that shameless torturing of nature to fit her to a mere pedantic and unintelligent convention which was practised by the men who made landscape gardening a century or so ago as formal as the worst examples of degenerate precision in garden design.

It must also be remembered that success in landscape gardening comes from consideration of many small details as well as from correct observance of large principles. Not many designers are fortunate enough to have at their disposal a site which needs nothing more than simple regulating and bringing into shape, one which has most of its beauties ready-made. Even when the general features of the ground lend themselves well to effective development there is almost always much to be done in the way of filling up and. improvement before the right artistic result is obtained. Unsightly objects outside the boundaries of the garden have, perhaps, to be hidden by judicious planting, or the outlook from the house has to be improved by the removal of trees which block the view; the existing vegetation has to be thinned to give the house more light and air, or has to be made more dense to afford protection from cold winds. Practical questions, like the provision of a tennis lawn, or a kitchen garden, have to be taken into account, and such necessary adjuncts to the house have to be dealt with discreetly so that they may fulfil their purpose adequately and yet not seem obtrusive or out of place in a well-imagined scheme. It is in the planning of a garden which is picturesque and yet of practical utility as a pleasure ground that the designer can best prove his capabilities; by his distribution of the details, which are of definite importance to the owners of the place, he shows to what extent he has mastered the essentials of his craft, and by his manner of harmonising these details with what may be called the pictorial intention of his plan he gives the measure of his artistic perception.

There is another matter which must receive from the landscape gardener a considerable degree of attention, a matter which is more important than it might appear to be at first sight. If, as seems reasonable, naturalistic gardening is regarded as being more or less akin to picture painting, it follows that it is subject to some of the xxviii 
same laws by which the artist is guided in dealing with his canvases. Form and colour have certainly to be taken into account by the garden designer, and he must have a thorough understanding of the manner in which composition lines should be adjusted so as to produce their proper decorative effect. In arranging the forms of his garden he must choose those trees and shrubs which by their variety of shape and growth will give what is required in the way of contrast of outline, and he must decide where masses of vegetation are necessary, and where single trees or groups of trees should be placed to diversify open spaces which would look bare and empty without some details to break their regularity. In devising colour effects he must consider not only what can be done by the use of flowering plants, but also how he can play upon that scale of tints which is provided in the foliage of the trees with which the large masses of his design are composed. He has a wide range within which to work, and he has only to refer to nature to see what scope there is for the exercise of his faculties as an artist.

In the adjustment of his composition lines he is obviously limited to a great extent by the necessity for making the best of what beauties the site on which his garden is to be laid out possesses naturally. But his sensitiveness to refinements of form will enable him to judge how these beauties can be emphasised and how the additions he proposes can be kept in character with what already exists. Restless lines, or lines that are irregular merely for irregularity's sake, imply insufficient consideration, and are the mark of inefficiency in design : there must be, not only in the ground plan of the garden, but in its elevation and sky-line too, a real suavity and elegance, a true grace of proportion, and a studied ease of arrangement which conceals the artifices by which the naturalistic result has been attained. There is clearly no place for narrow conventions in the right kind of landscape gardening; what is needed is rather largeness of view and that ready adaptability which comes from study of nature and from the cultivation of rsthetic instincts; the man who works by rule and depends upon a preconception only is inevitably doomed to fail.

This is in some measure true of the formal gardener as well, though, perhaps, in this branch of the art there is less possibility of breaking away from ancient tradition. But in formal gardening there is ample scope for the exercise of a just perception of form and a real love of colour, and there is the fullest opportunity for displaying ingenuity of design. Only it is the architect's mind that is needed here rather than that of the landscape painter-the architect's instinct 
for firmness and precision of line, for exact balance, and accurately regulated proportion. His forms and his colour masses must be more strictly studied and more distinctly spaced than those of the landscape gardener, because pre-arranged accident does not enter into his calculations. He guides nature along lines he has laid down beforehand; he does not follow her and adapt himself to her moods. Of the two types of designers he is in many ways the one who has the larger problems to solve, who has to overcome the greater difficulties before he can hope to succeed. But for him, too, there is an evident necessity for openness of mind. If he thinks only in the past, and is content merely to imitate the works of his predecessors, if he believes that in their theories and practice all the possible principles of gardening have been defined, he will do little to help garden-making to take once again its right place among the arts. 


\section{NOTES ON THE ILLUSTRATIONS}

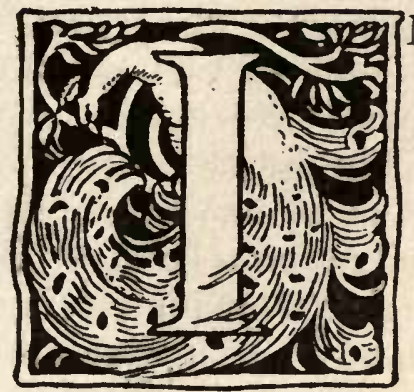

$\mathrm{N}$ the pictorial treatment of garden subjects it is important that the particular charm and character which they possess should be sympathetically suggested. To make a garden picture a mere piece of obvious realism, a simple representation of pretty details, is by no means enough; each place has an individuality of its own and a distinctive atmosphere which needs to be studied and expressed. The ordinary topographical record, which states facts without sensitiveness and gives a sort of diagram of the general laying-out of the garden, is far from satisfactory, for it conveys no real impression of those subtleties of effect which were the intention of the original designer. It misses the true sentiment of garden-making, and makes commonplace what should be fascinating in its quaint variety and daintiness of feeling.

The principle which has been followed in the illustrations of this number has been, as can plainly be perceived, to avoid as far as possible simple topography, and both in the selection from the material available, and in the treatment of the motives illustrated, to secure the right atmosphere and sentiment of the well-designed garden. In the execution of the large series of photographs from which those reproduced have been chosen, Mr. W. J. Day has entered sincerely into the spirit of the work, and has realised fully what are the pictorial possibilities of the places with which he has had to deal. Consequently it may fairly be claimed that what is presented here illustrates adequately the best type of gardening, and-in accordance with the traditions of THE STUdIO-puts in the first place the artistic aspects of a subject which has been far too often treated with an excessive amount of matter-of-fact actuality. It can be seen, too, that all phases of garden-making have been recognised and considered, and that old and modern work alike has been represented; so that the series of illustrations sums up sufficiently the results which have been attained by many generations of designers.

Care has especially been taken to present the salient features of the various places, those features which make them notable as examples of a pleasant and interesting art, and which deserve the attention of all students of gardening at its best. These features have a definite significance, for they illustrate the manner in which art can be associated with nature and used to enhance her charm. Their value can 
be all the better appreciated because the reproductions show them as they are, in the setting devised for them by the designer and among surroundings which nature has perfected and made appropriatebecause they have their right positions in a completed picture, and are not detached from the accessory details with which they are necessarily required to be in proper relation. The garden seat, the sundial, the fountain, or the group of statuary must be judiciously placed or it may become an annoying incongruity even when it is in itself a beautiful object; and the test of the judgment used in placing it is the manner in which it lends itself to treatment as the central fact of a reasoned composition.

The garden designer, it should be remembered, must work with an eye to the future, and in his plan he must take account of what is to be in years to come. The design which looks well on paper may easily prove impossible to realise, and is quite likely to be thrown out of all proportion by processes of nature, the consequences of which have not been foreseen. But when these processes have been deliberately prepared for and the inevitable effect of the growth and thickening of vegetation has been allowed for in the carrying out of the plan, the lapse of years only helps to develop an intention which was from the first sound and discreet. The illustrations given show, in the majority of instances, the evolution of a design made many years ago, and so they are to be taken as records of what can be accomplished by controlling nature intelligently, and by inducing her to do her work along the lines laid down by men with shrewd foresight and ingenious minds. These men made her help them, as they understood that without her assistance much of their labour would be unprofitable, and what came of this alliance we can well judge to-day, because the results are available for our inspection.

The almost endless possibilities of garden-making when it is carried on in accordance with the dictates of common sense and without slavish adherence to fashion, are clearly indicated in the series of illustrations. Many effective comparisons can be made between the various places represented, comparisons that are as instructive as they are interesting, and that prove how little a preference for a particular style makes necessary any adherence to stereotyped methods of design or any repetition of a stock formula. In both formal and landscape gardening there is obviously the fullest scope for invention, and the only restriction that need be observed is the salutary one which forbids to the designer any lapse into those extravagances of manner which are to be condemned as foolish travesties of nature. xxxii 
For instance, what better contrast could be desired than that which can be made between the stately pleasure grounds at Wilton House (Plates CXXXIII to CXXXVI) and the quaint, precise, and studied garden at Old Place, Lindfield (Plates XCIV to XCVII). Both are formal in the sense that they owe their beauties to deliberate contrivance ; but while Wilton is a typical example of classic design, and has many of the finer characteristics of the Renaissance manner, Old Place is essentially illustrative of the methods of the English designer who had learned to combine into a harmonious whole the best features of English and Dutch gardening. Again, it is interesting to compare the sumptuous and careful elaboration of the formal gardens of Blenheim Palace (PLATES XV to XIX) with the not less careful but more quietly effective completeness of Brockenhurst Park (Plates XXVII to XXX); or the somewhat exaggerated primness of Longford Castle (PLATES LXXXVIII and LXXXIX) or Canford Manor (Plates XXXIII and XXXIV), with the old-world charm of Penshurst Place (Plates CIV to CIX). At Longford, and in a less degree at Canford Manor, the Italian spirit is very perceptible, but at Penshurst the garden laid out, since the middle of the last century, under the direction of George Devey, the architect, revives most happily the particular qualities of the English work of the best period, before the eccentricities practised in the earlier years of the eighteenth century brought formal gardening into disrepute.

The same atmosphere which makes Penshurst delightful is very apparent in such places as Groombridge House (Plates LXII to LXIV) and Clevedon Court (Plates XXXVIII to XL), both of which, with their terraces and clipped hedges, their rich masses of foliage and their gay flower borders, are typical instances of gardenmaking on essentially English lines. They respect tradition, but in the treatment of details they show the degree of freedom necessary to prevent them from becoming merely illustrations of the use of a set convention. Similar qualities distinguish houses like Hatfield (Plates LXX to LXXIII) and Holland House (Plates LXXVII to LXXXI), where the gardener's craft is used to enhance the architectural effect of noble buildings and where the alliance between nature and art is given the fullest opportunity of making its meaning felt. Montacute House (Plate XCI) is another place of the same kind; like Hatfield, it derives a most persuasive dignity from the happy combination of architecture with the regulated wildness of nature, and from the use of formal details to give cohesion and consistency to a well-planned design; and at Ham House (Plates LXV and LXVI), though the combination is xxxiii 
less deliberate, the relating of the garden to the building it surrounds is exceedingly judicious and quite agreeable in its result.

As further examples of this association The Hall, Bradford-on-Avon (Plates XXIII and XXIV), Brympton House (Plates XXXI and XXXII), and Orchardleigh Park (Plates XCVIII to CI), are especially notable. The first two illustrate admirably the value of the stately and well-proportioned terrace with fine flights of steps as a connecting link between the house and the grounds, and prove very decisively how mistaken were the earlier landscape gardeners when they neglected the opportunity of securing such a feature as a starting-point for their garden design. Orchardleigh Park shows a different treatment of the terrace, but one which lacks neither picturesqueness nor beauty of effect, and one, moreover, which must be commended for its elegant arrangement of lines. At Ammerdown Park (Plates IV to VIII) the architectural effect of the immediate surrounding of the house is more than ordinarily persuasive; a very correct judgment in the spacing of the different parts of the approach can be recognised, and the formality of the design, carefully contrived as it is, does not in any way exceed legitimate bounds. This formality does not, however, extend to the garden, in which nature has been allowed to riot pleasantly and to hide by a free growth of foliage many of the terrace walls. A similar profusion can be seen at Stratton Park (Plates CXVI to CXVIII), where the distinguishing note is a kind of intentional wildness, a prearranged confusion which is quite happily unconventional.

A touch of the same deliberate carelessness can be seen in the garden at Hartham Park (Plates LXVII and LXVIII) where the severe lines of the architectural laying-out - an excellent piece of modern work-have been softened by what seems at first sight to be the accidental growth of vegetation in unexpected places. Whether this device is entirely legitimate is a question for discussion by experts; it gives, perhaps, a hint of neglect which has produced effects not really allowable in formal gardening. It would certainly be out of place in such gardens as those at Ashridge Park (PLAtes IX to XIII), where the dominant note is strict precision; and it would spoil the trimness of such places as Moor Park (Plates XCII and XCIII) or Taplow Court (Plates CXXI and CXXII), both of which are interesting examples of laying-out in the strictly correct manner. It seems more appropriate at Corsham Court (Plates XLI to XLIII) and at Paulton's Park (Plates CII and CIII), where variations from the exact design have apparently been contemplated and prepared for in the original plan; and it does not clash with the domestic charm xxxiv 
of Daw's Hill Lodge (Plates XLIV and XLV), a house that is delightful by its very absence of pretentiousness.

Among the other places which are illustrated some, like Dropmore (Plates XLVI to XLVIII), Eridge Castle (Plates LV and LVI), and Embley Park (Plates LI to LIII) combine formality and freedom in about equal proportions, and present a well-planned commingling of features which belong to both formal and landscape gardening. Others, like Bowood (Plates XXI and XXII) and Tring Park (Plates CXXIII to CXXVI), exemplify well the way in which the gardener can draw upon the recognised authorities for the various parts of his design, and can bring together within a more or less limited area the results of his study of several schools of garden-making. And another, like Sedgwick Park (Plates CXIV and CXV) shows how formality can be made fantastic and how a strict formula can be modified to satisfy a desire for a fanciful effect. To compare the arrangement of clipped hedges and an artificial sheet of water at Sedgwick with the management of similar features at Brockenhurst Park, for example, is decidedly instructive, for by this comparison it can be realised how little justified the opponents of formal gardening are in their contention that acceptance of certain principles of design must necessarily lead to unnatural regularity and repetition of conventional forms.

To a class of gardens that is particularly English in its main characteristics belong such places as Ven Hall (Plates CXXVIII to CXXX), Great Tangley Manor (Plates I, LVIII, and LIX), Broadands, (Plates XXV and XXVI), Beaulieu Palace (Plate XIV), the college gardens at Oxford (Plates XC, CXII and CXXXI), and those at Farnham Castle (Plate LVII), and the Bishop's Palace, Salisbury (Plate CXIII). They have a certain savour of antiquity, a solid dignity which comes partly from their associations and partly from the glamour which age has given them. Their charm is scarcely dependent upon subtleties of design; it results rather from an element of unexpectedness, from more or less surprising departures from rule which have come about accidentally during the lapse of years. There is none of this unexpectedness in a garden like that at Hinton Admiral (Plates LXXIV to LXXVI), where the hand of the skilled designer well acquainted with modern devices can be plainly traced; but it is pleasantly evident in the shady walks at Ven or in the quaint corner of the Bishop's Palace at Salisbury.

It is felt, too, very definitely in the Devonshire gardens, Chaddlewood (Plates XXXVI and XXXVII), Eggesford House (Plates XLIX and L), Greenway House (Plates LX and LXI), and Killerton 
(Plates LXXXIII to LXXXV), and in the Cornish place, Pentillie Castle (Plates CX and CXI), all of which derive much of their specific character from the help which nature has given to the designer. These are in the best sense of the term landscape gardens in which the ordering of details has been made to bear a direct relation to the natural character of each place. The configuration of the site has determined the plan, and the laying-out has been more in the direction of a development of what was already there, an adaptation of existing features, than in the direction of preconceived and calculated formality. Nature has not been unduly chastened; to a large extent, indeed, she has had her own way and the gardener has worked at her dictation and under her guidance.

As examples of the reversal of this process, of the use of nature to complete an entirely definite plan, the gardens at Abbotsbury Castle (Plates II and III) and Swaylands House (Plate CXIX) are noteworthy. The effects here have been prearranged, and what seems to be accidental wildness has been led up to by human ingenuity. The Abbotsbury garden is as much a composition as the most precise of the formal designs, and that at Swaylands-one of the most elaborate rock gardens in England-has been built up laboriously with a purely pictorial intention. Both show well what an illusion can be obtained by clever artifice, and how the naturalistic suggestion is possible in what is in principle formal gardening. In work of this character precise methods are employed to produce an informal result, but it is only by the preliminary precision that the subsequent informality can be made credible. There remain to mention the illustrations of bits in the gardens at Kingston Lacy (Plate LXXXVII), Inwood House (Plate LXXXII), and Walhampton Park (Plate CXXXII). The Kingston Lacy and Inwood subjects show ways of treating that favourite garden accessory, the sundial ; and the Inwood example in particular is memorable because it is an unusually ingenious piece of work, an instance of the clever use of the gardener's craft. The bit from Walhampton Park illustrates the application of statuary, when divorced from architectural surroundings, to the ornamentation of open pleasure grounds. The figure has a certain pictorial effectiveness in its relief against the dark foliage of the ilex-trees, and serves as the high light in a tone arrangement which without some such contrast might seem a little too ponderous.

The coloured plates in this number have a specific value as instances of the adaptability of garden subjects to the painter's purposes, and of the varicty which is possible in the treatment of this class of xxxvi 
NOTES ON THE ILLUSTRATIONS

material. Miss Stannard's three drawings suggest frankly the charm of those unambitious gardens which are chiefly fascinating by their brilliancy of colour and profusion of flower growth; and Miss Adie, by her two studies at Hampton Court, shows what kind of pictures can be made in those more elaborate pleasure grounds which have been laid out by a designer who worked originally with a view to stately developments. Mr. Elgood and Mr. Rowe set forth the beauties of places which are types of what the garden should be when it is intended to satisfy that love of the picturesque which has called into existence in this country so much that is worthy of careful preservation. At Great Tangley Manor, Penshurst, and Brickwall the formal gardener has done his work with the rarest judgment, and what exists now in proof of his skill is legitimately the delight of the artist who can appreciate how intimately nature and art can be associated.

A. L. BALDRY. 


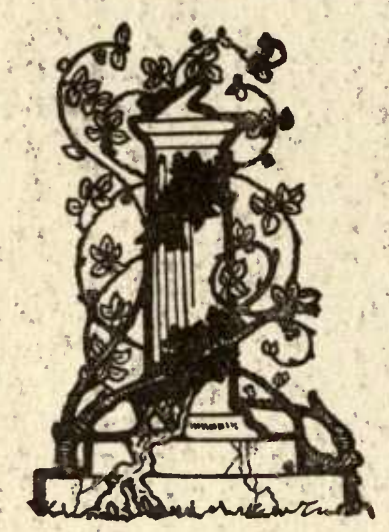




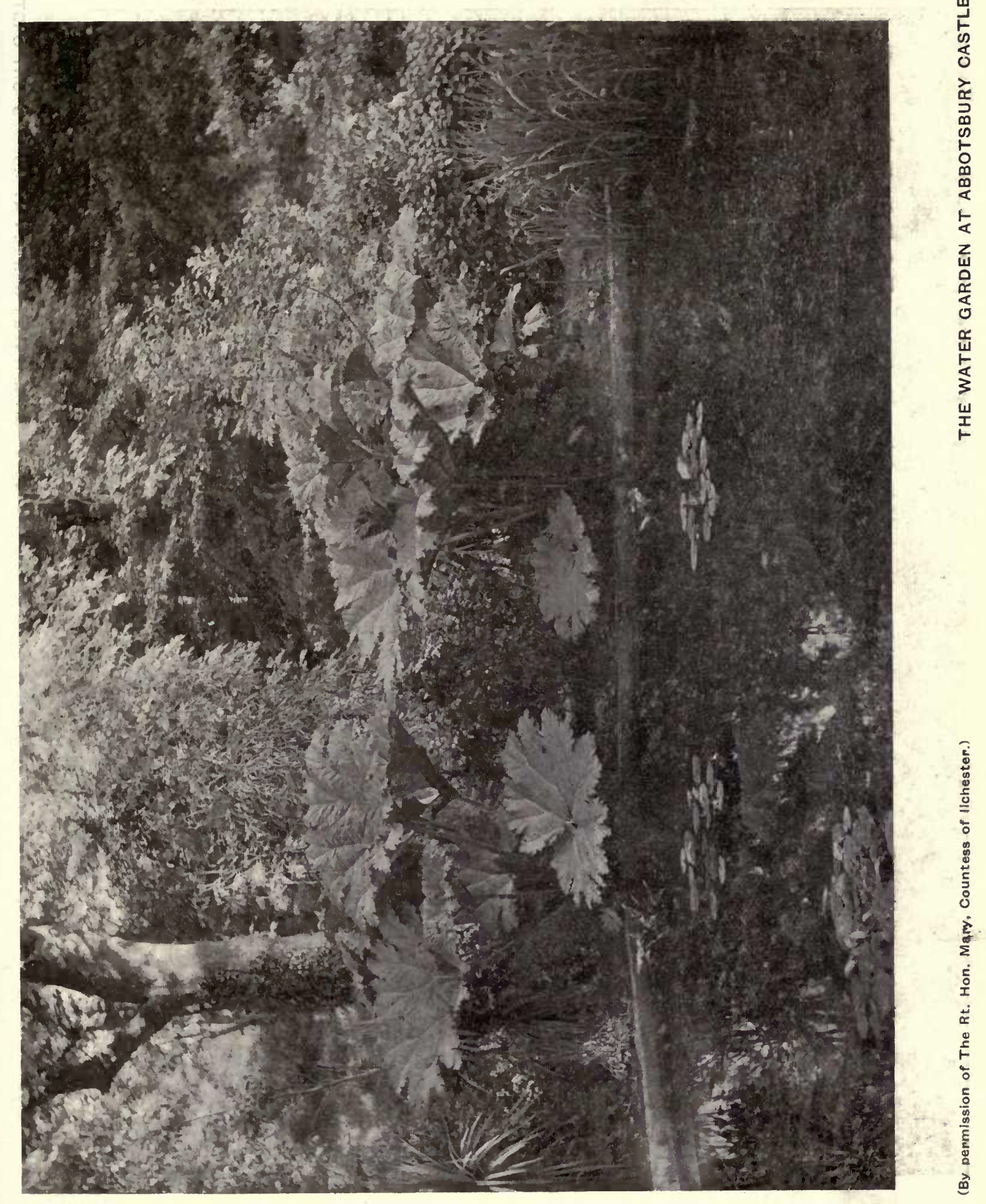




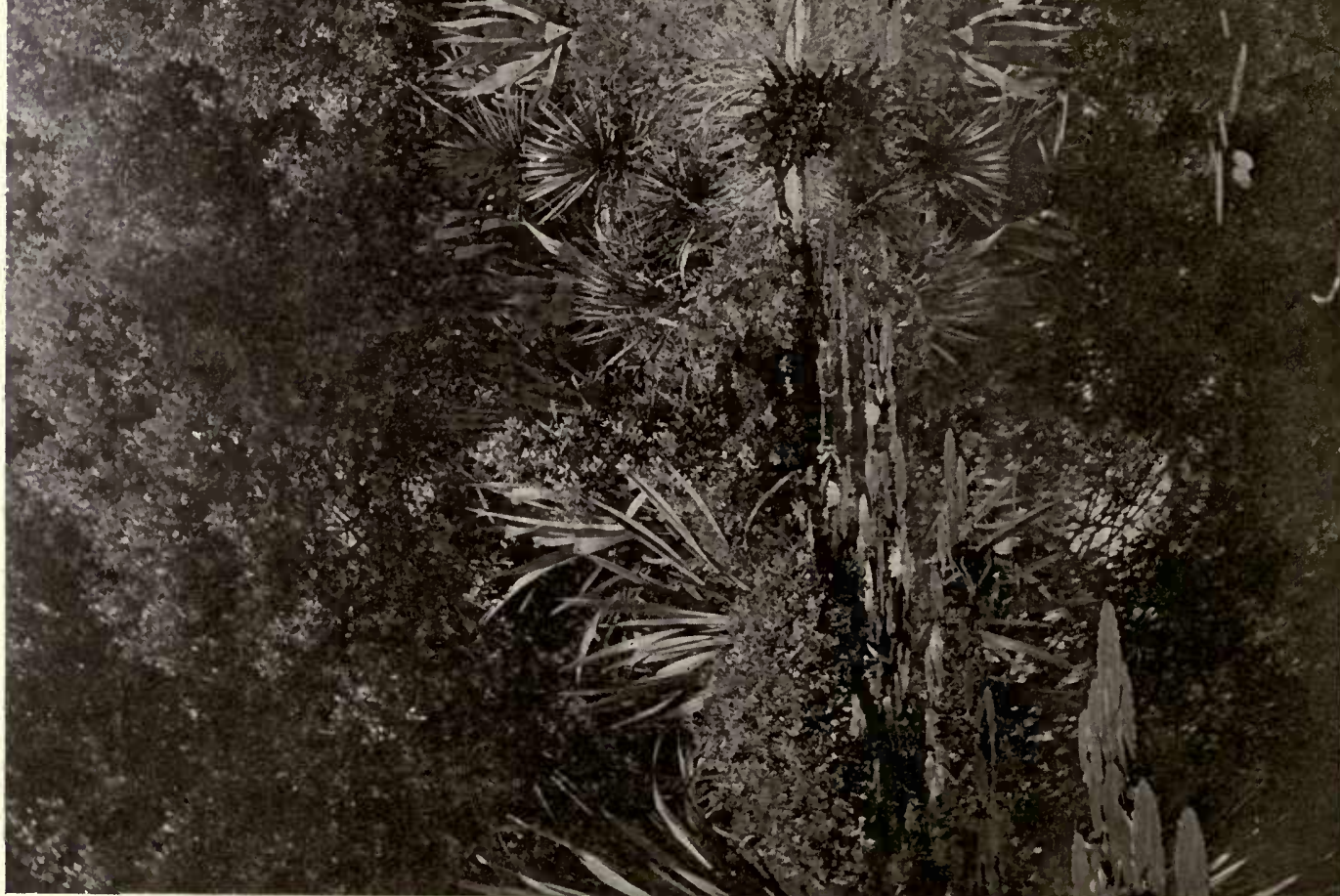




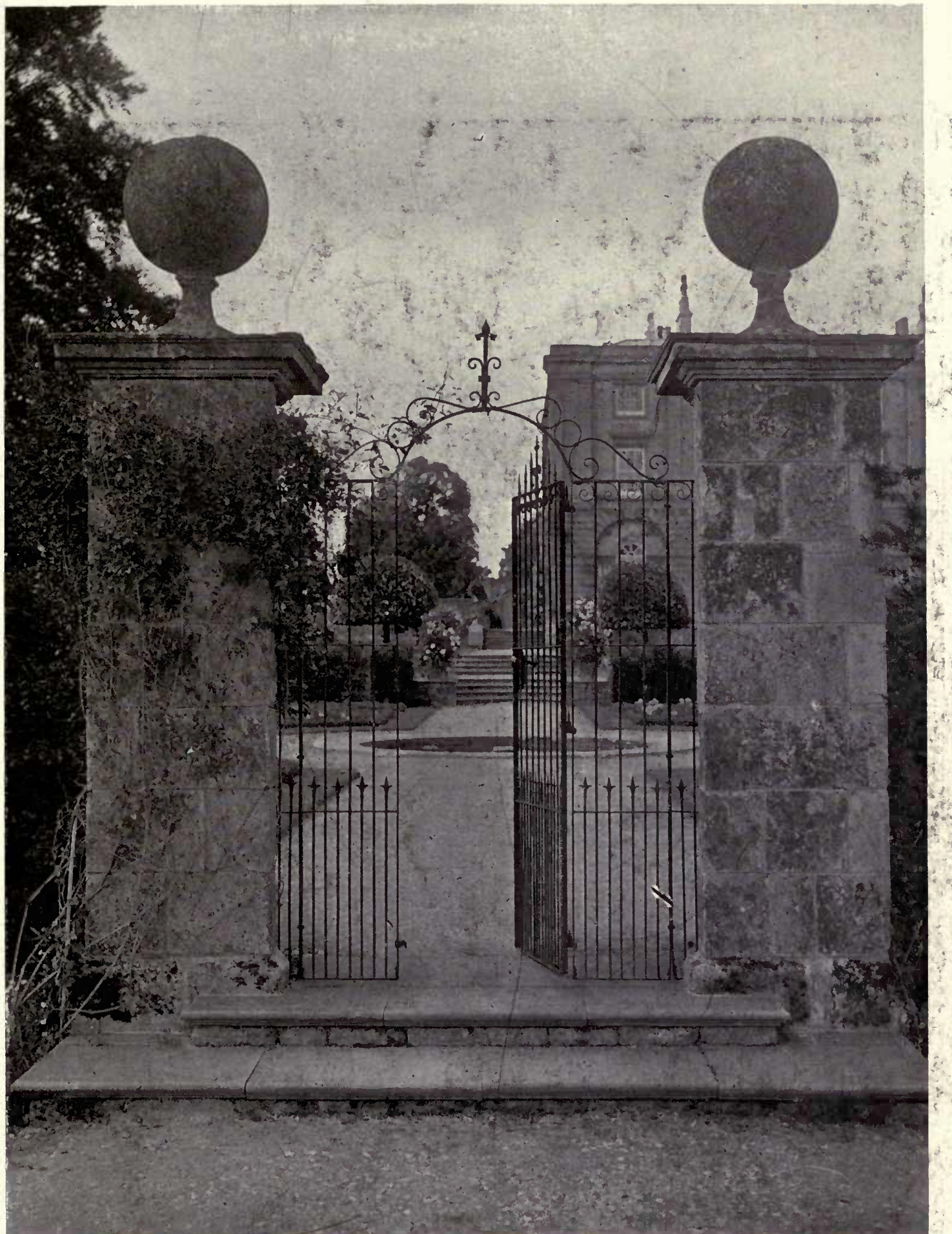




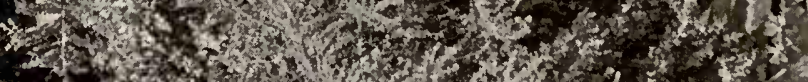

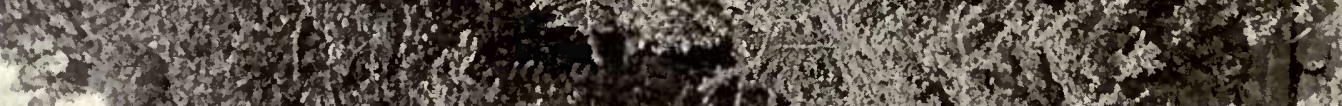

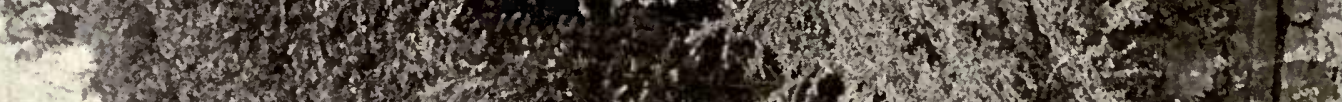

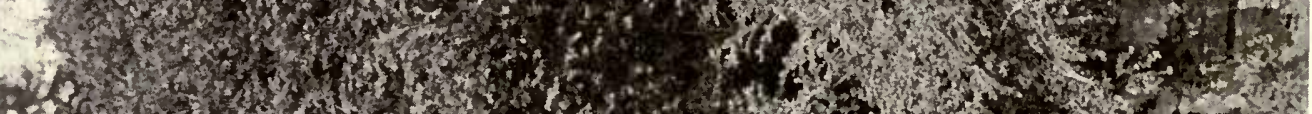

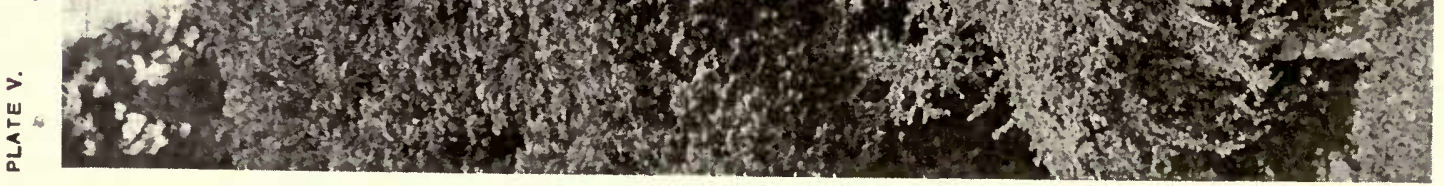









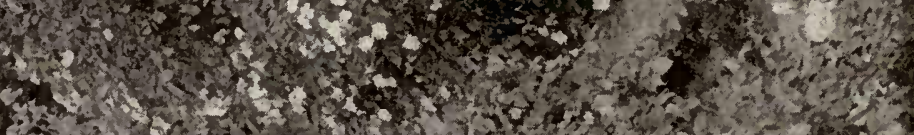

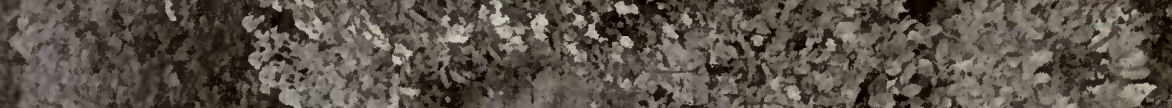

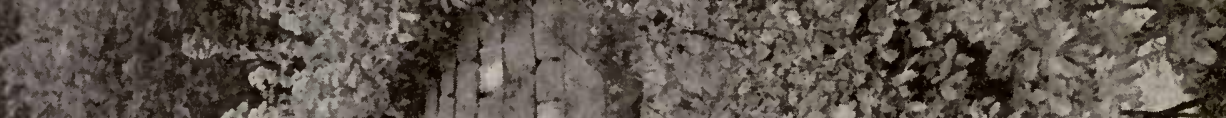

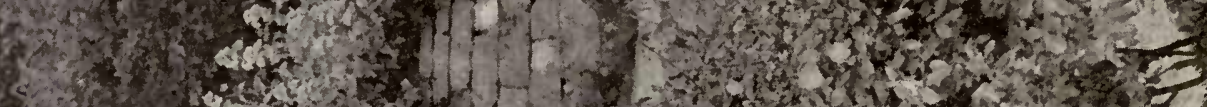

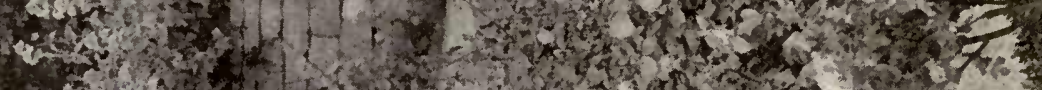

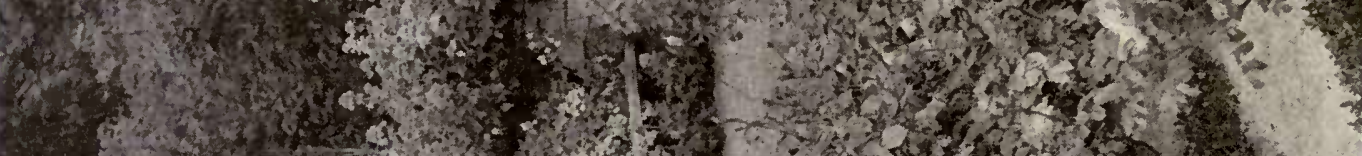




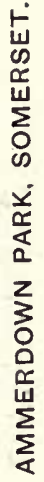

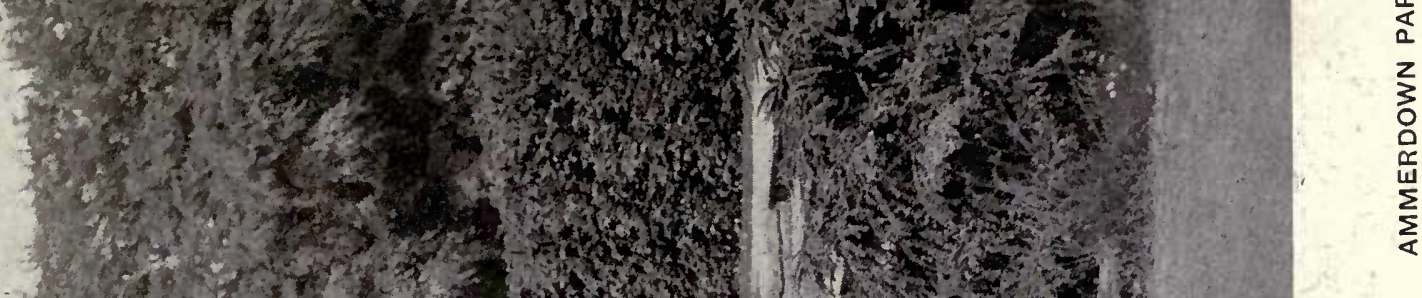

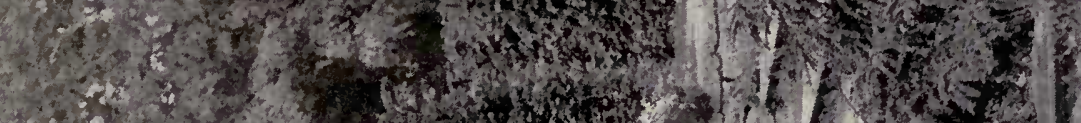

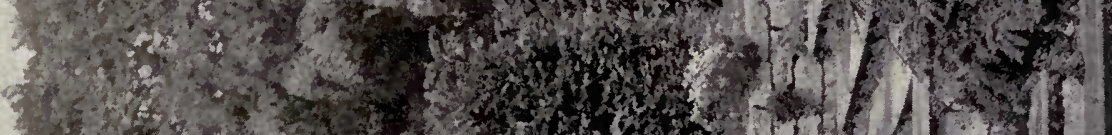

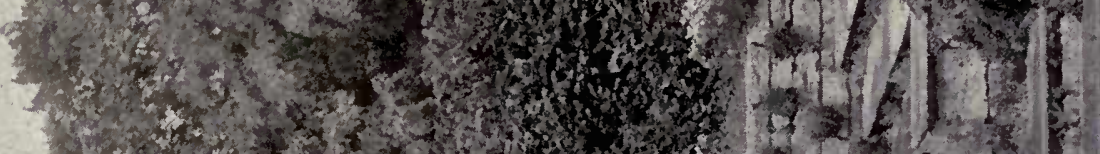

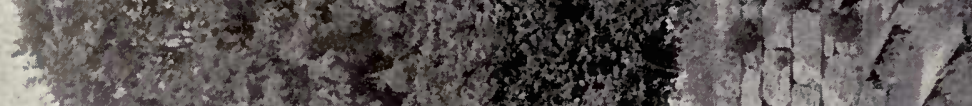
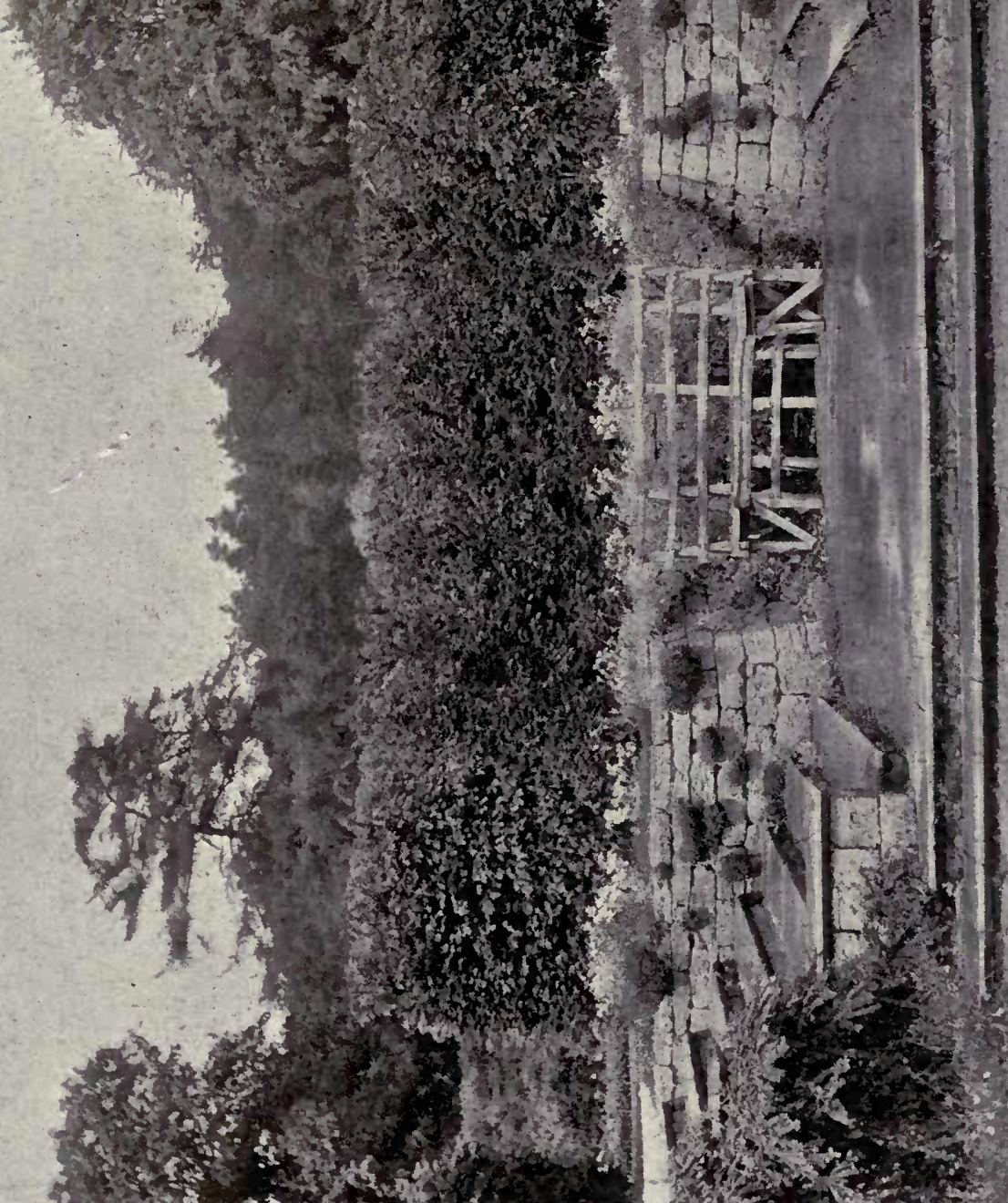

a. 1.0
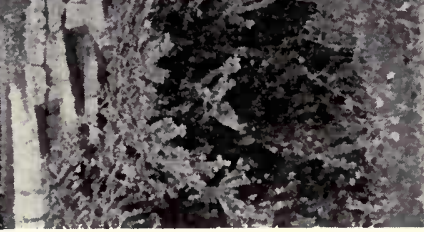

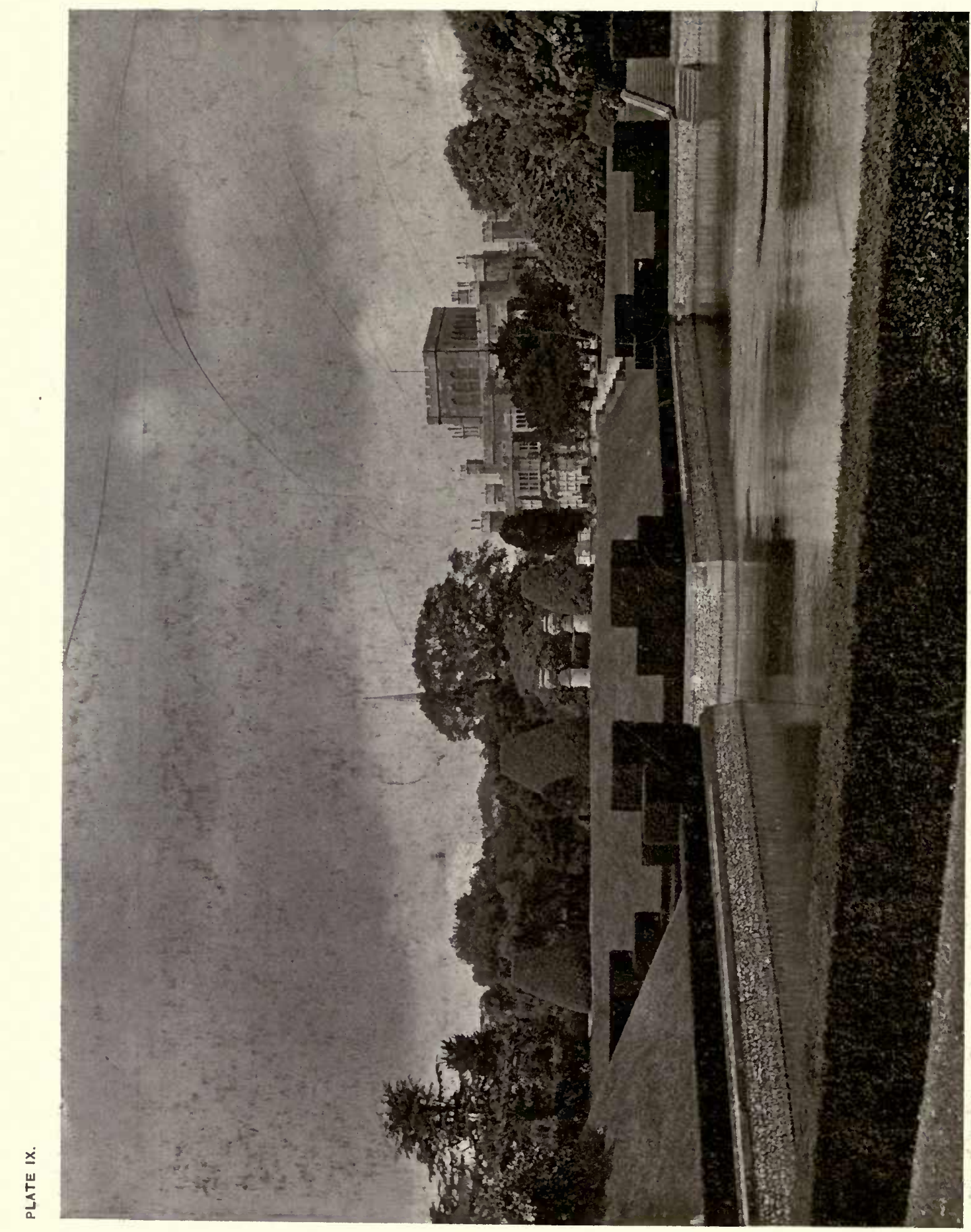

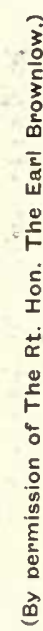




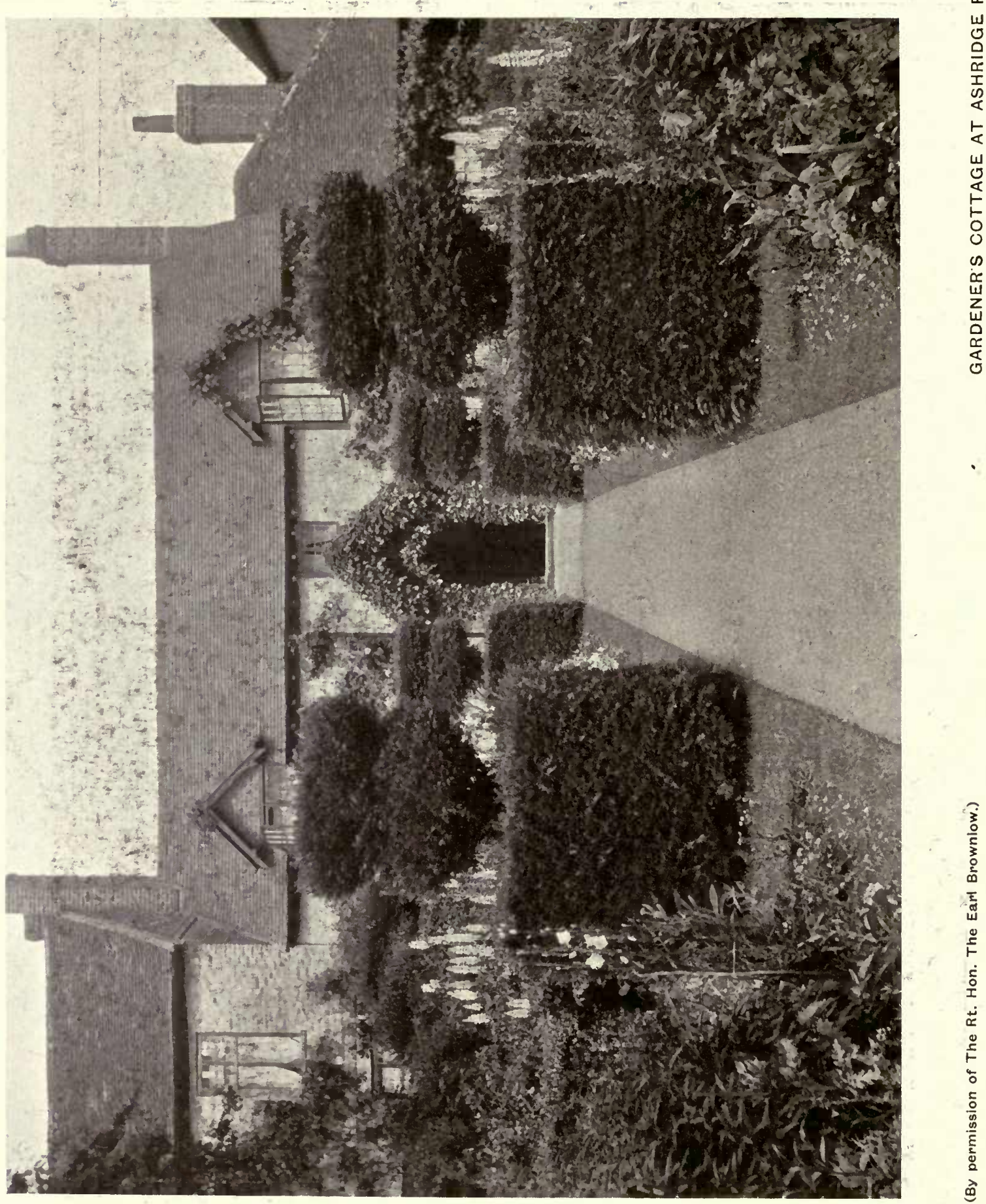




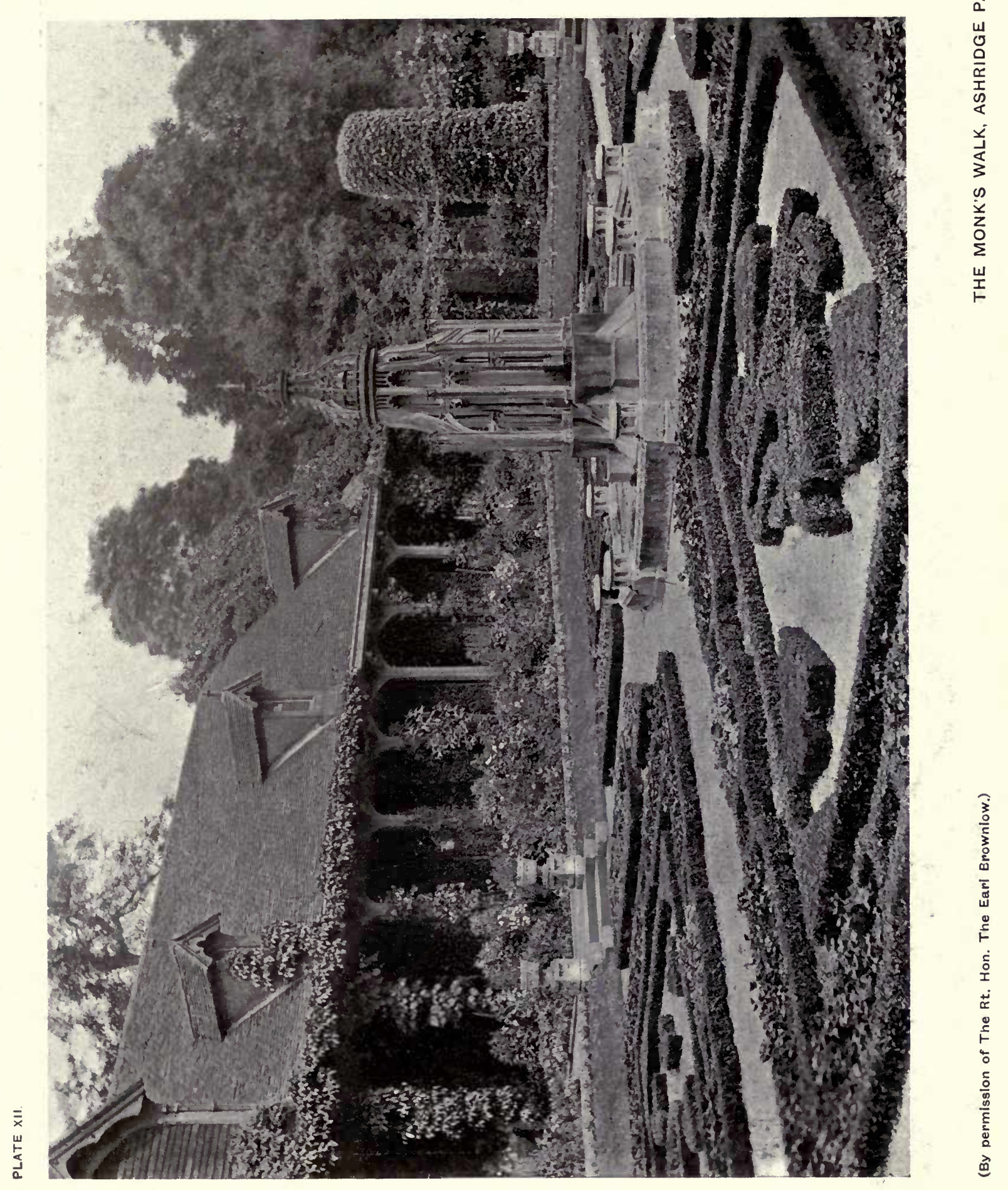




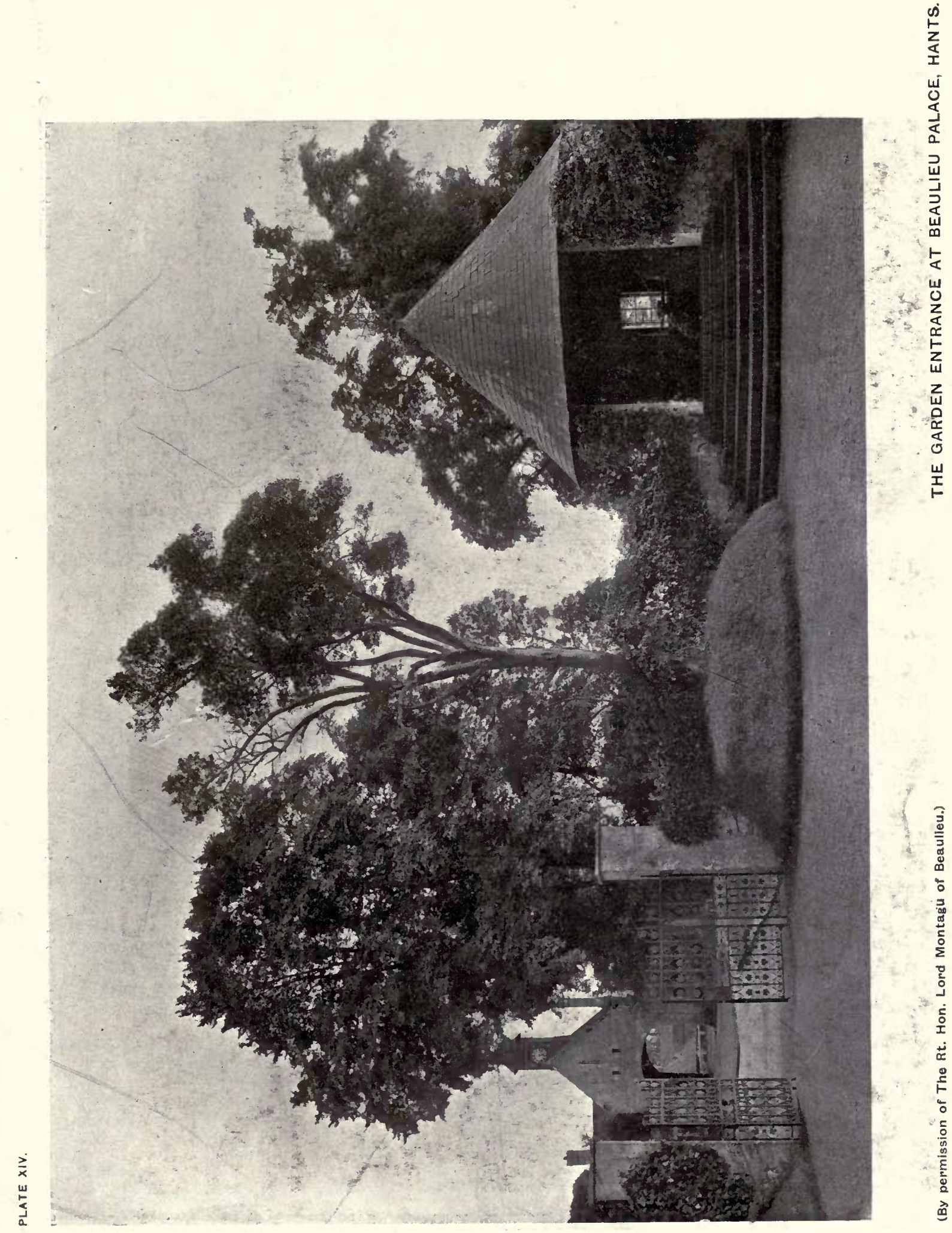




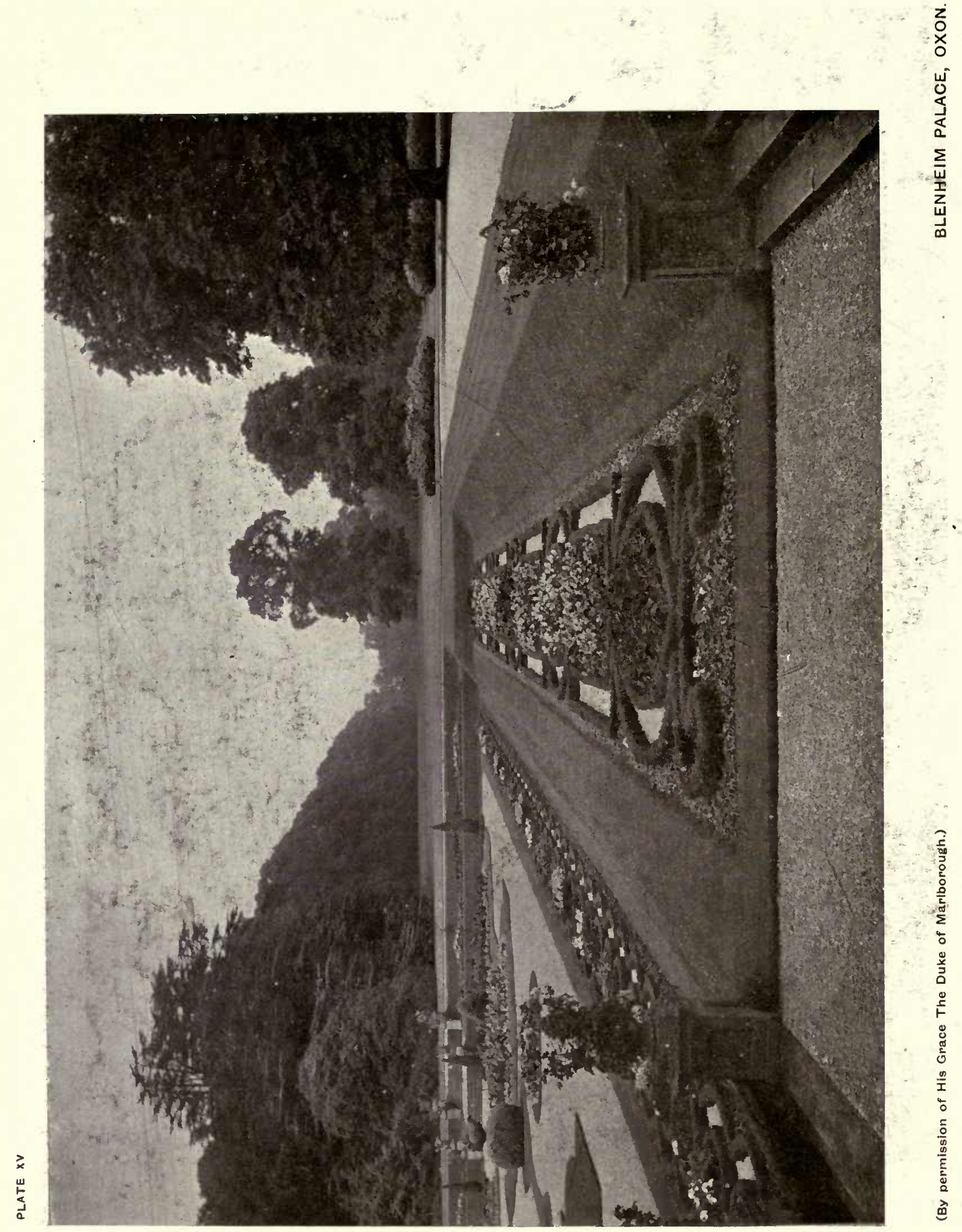




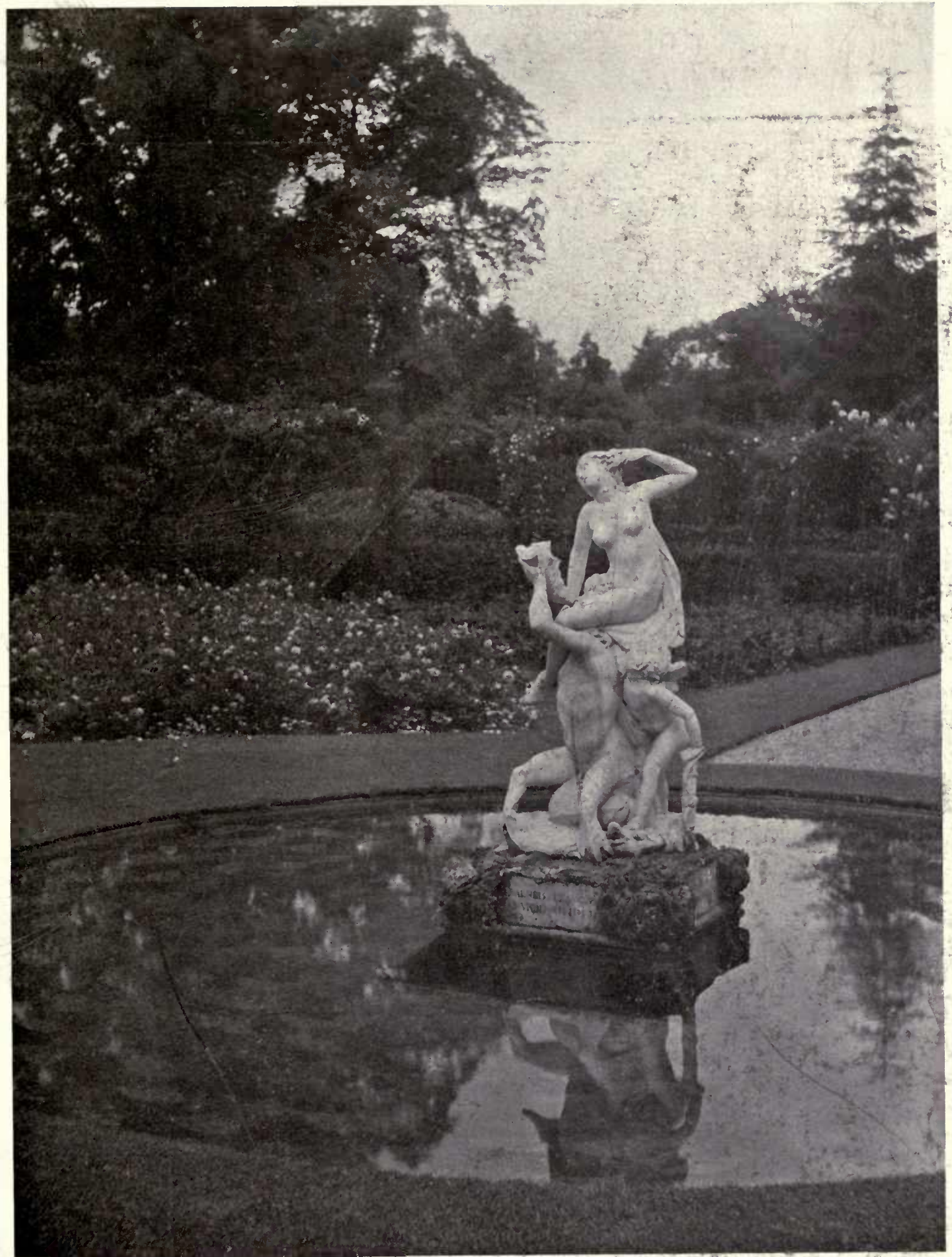




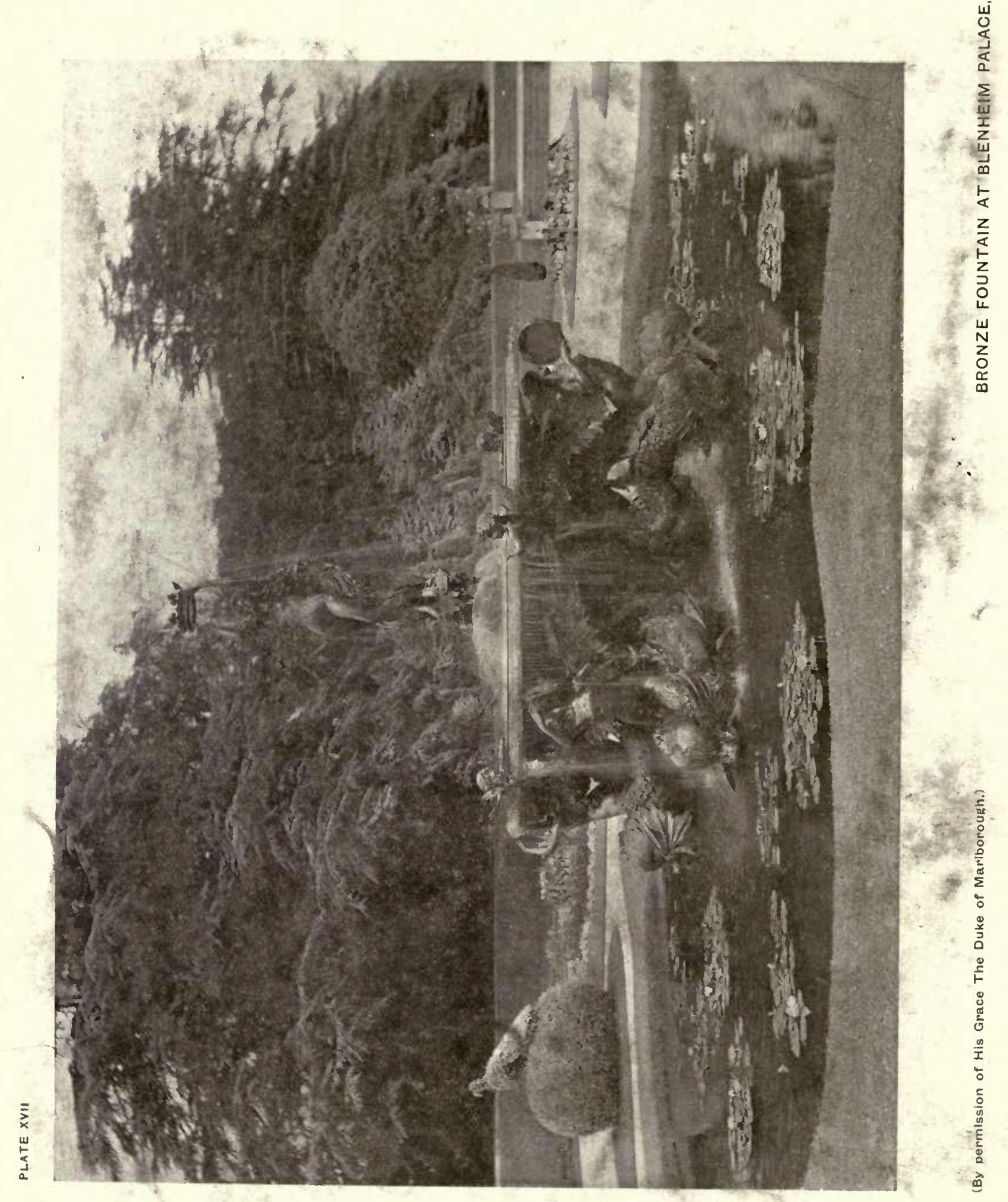









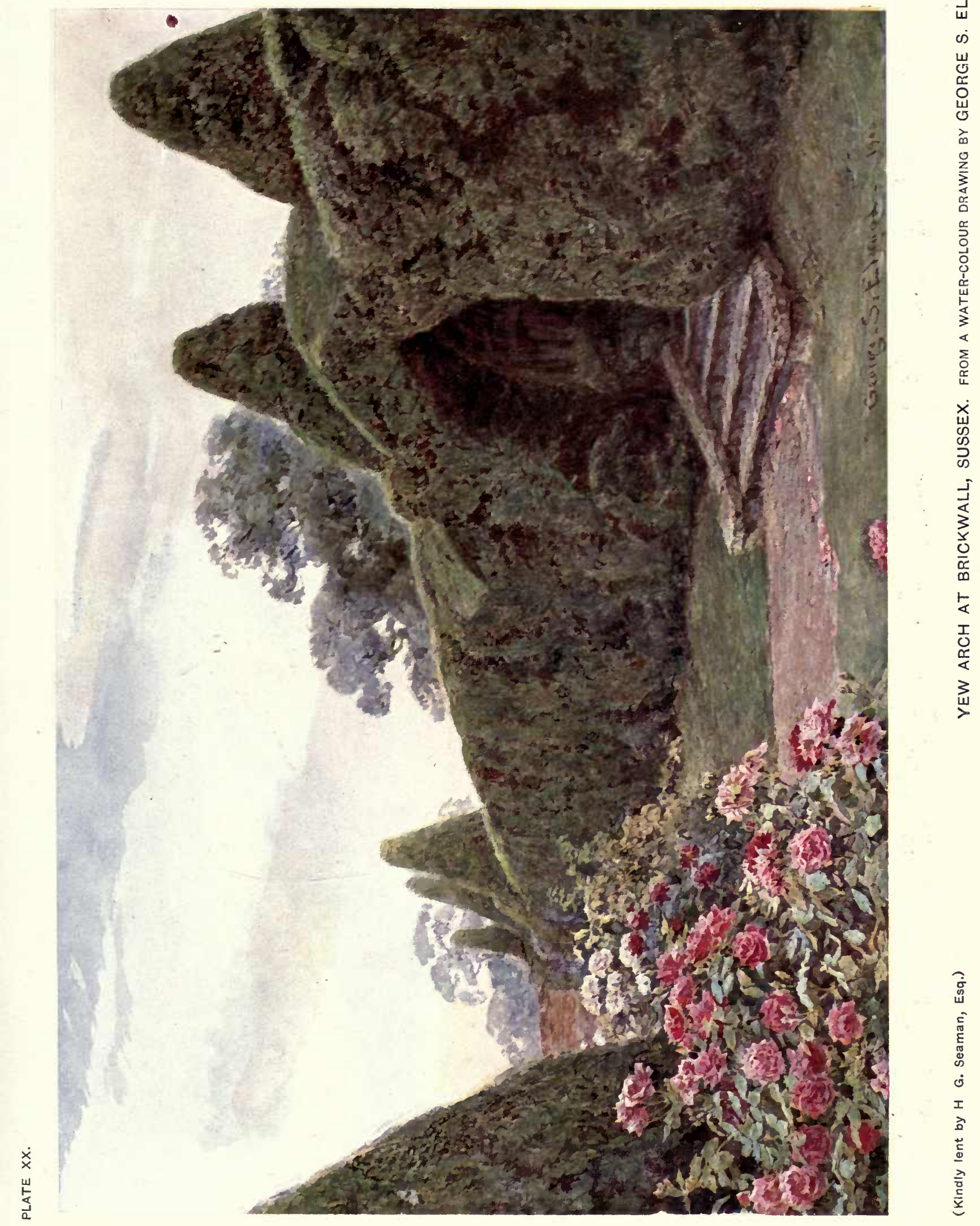




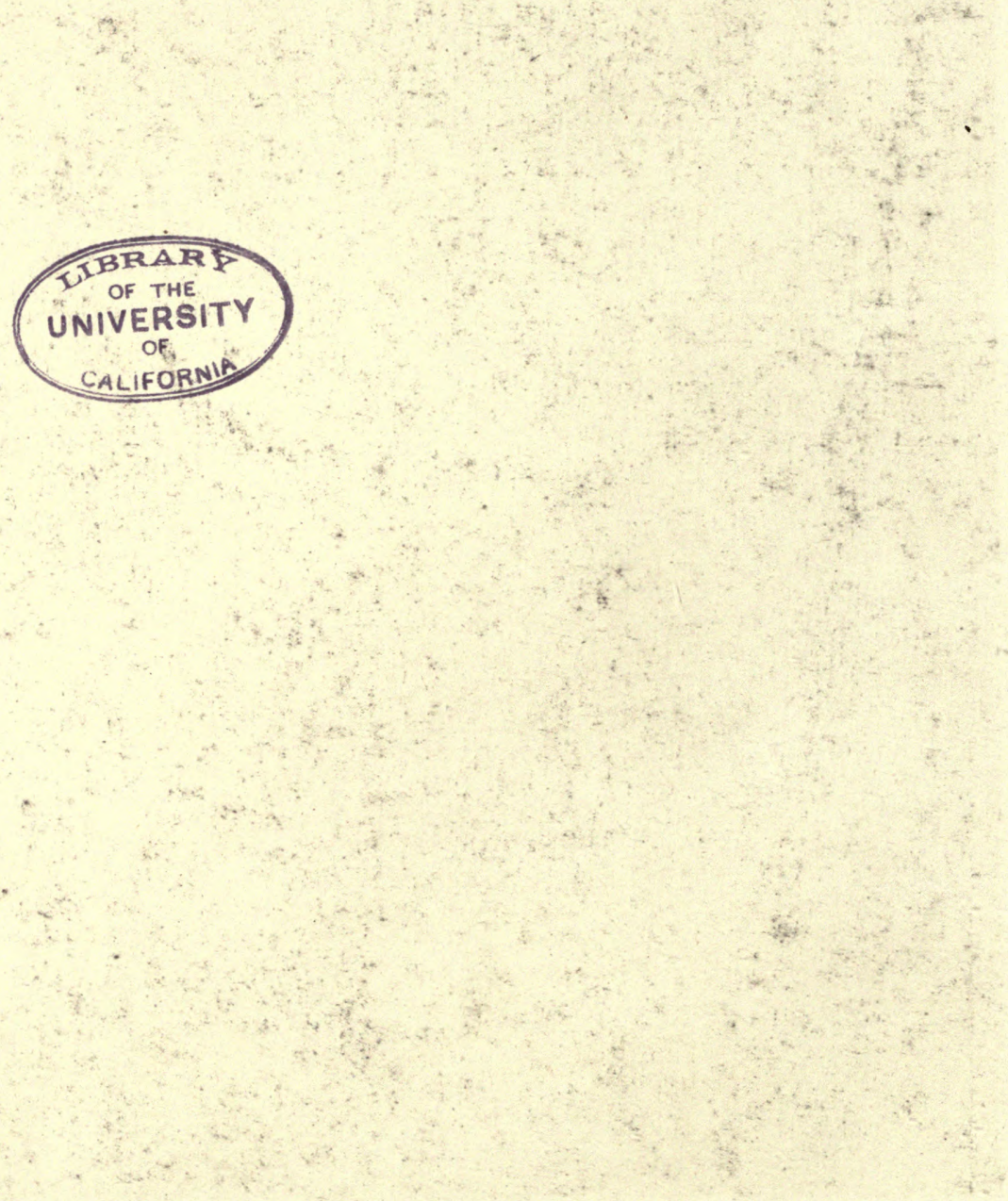




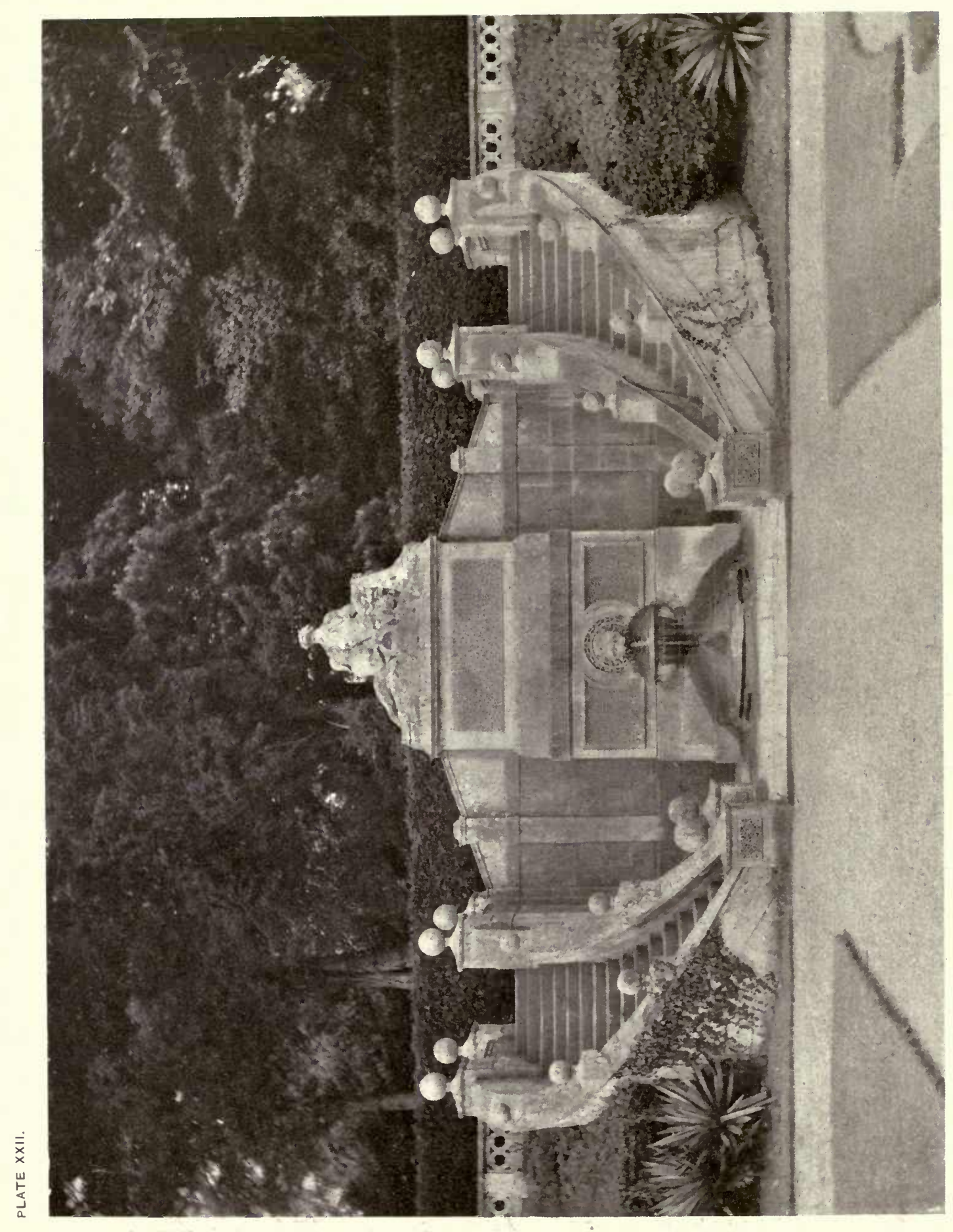

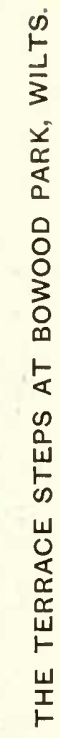

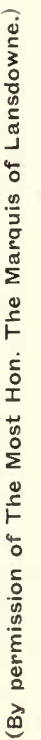




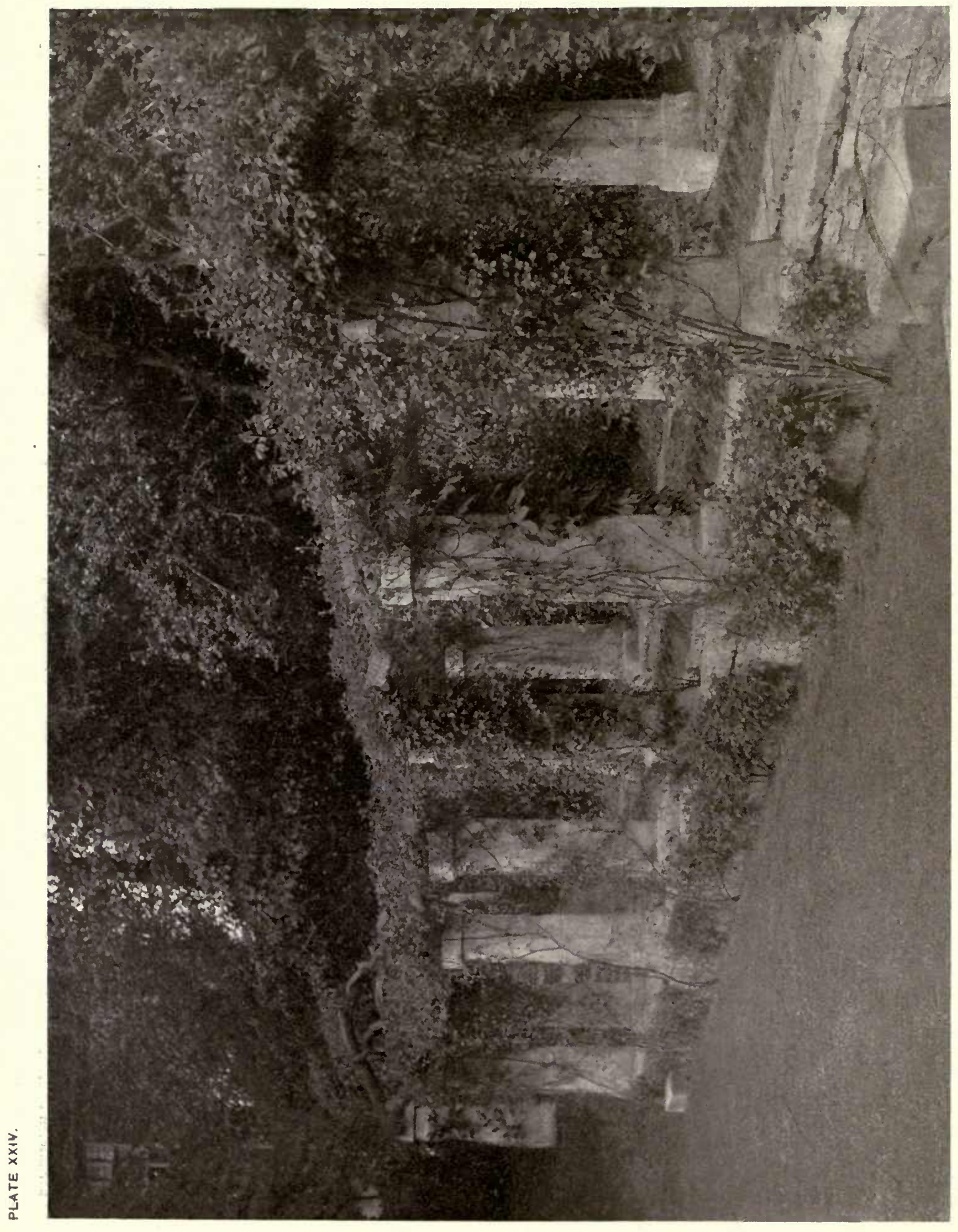




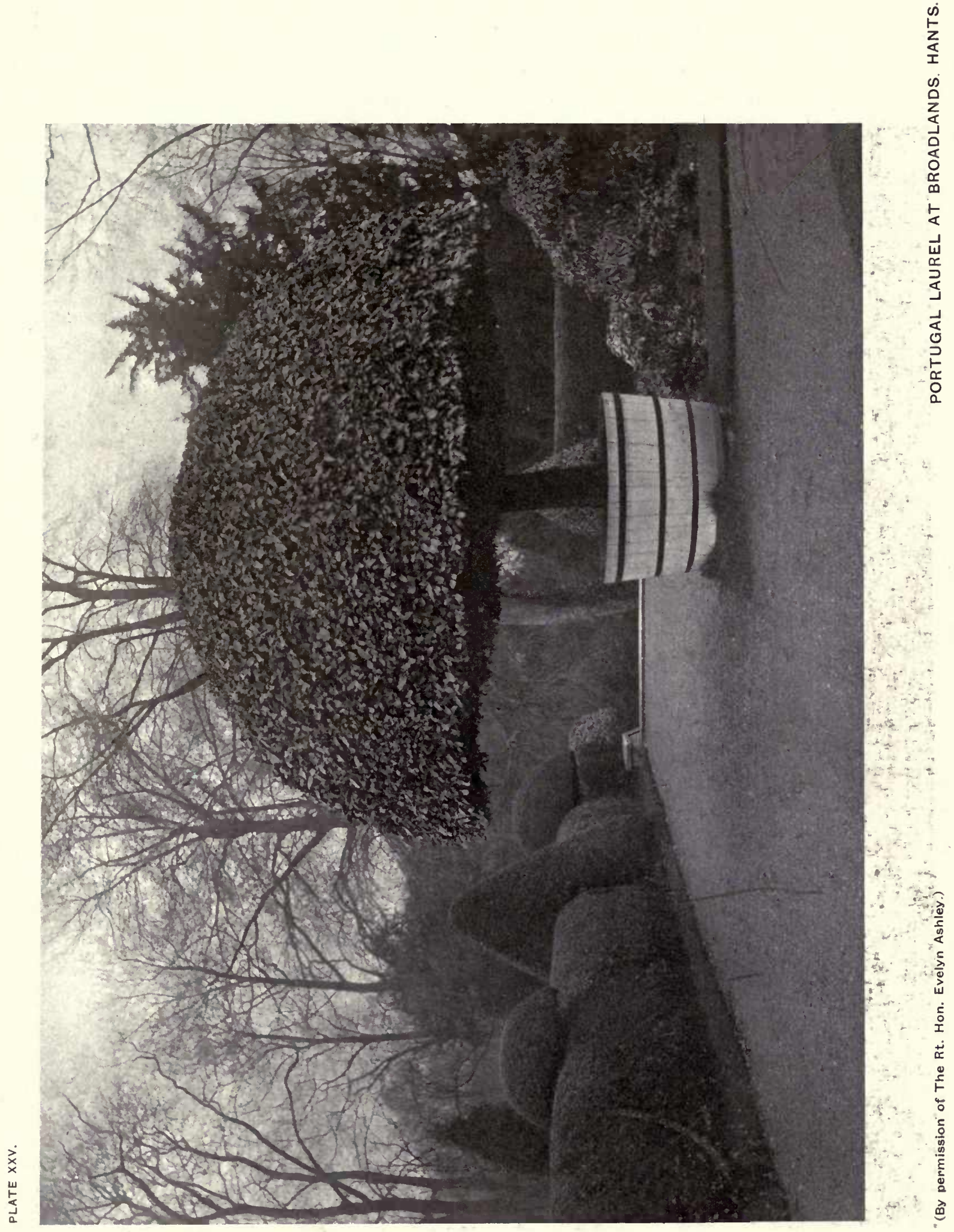




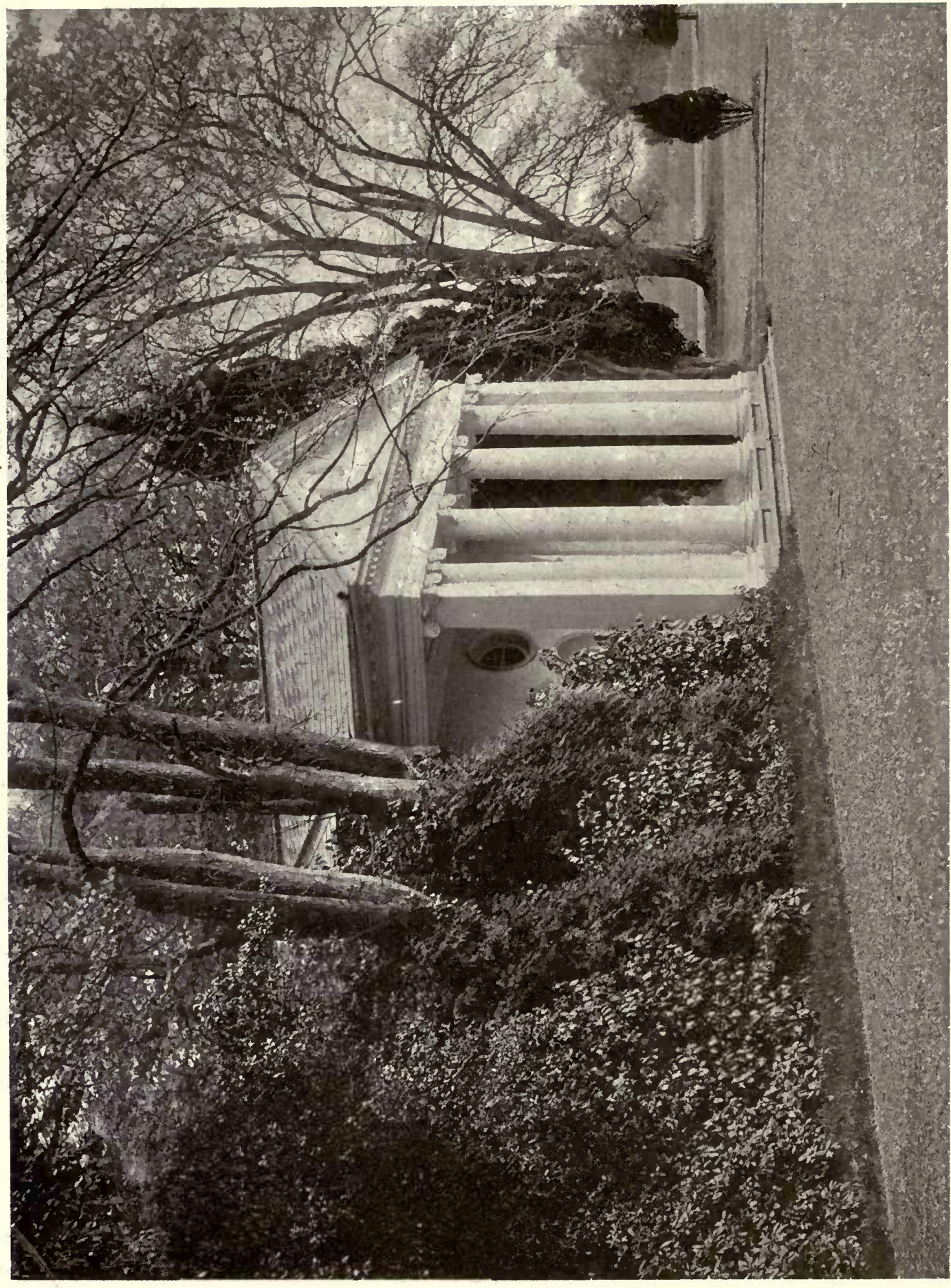




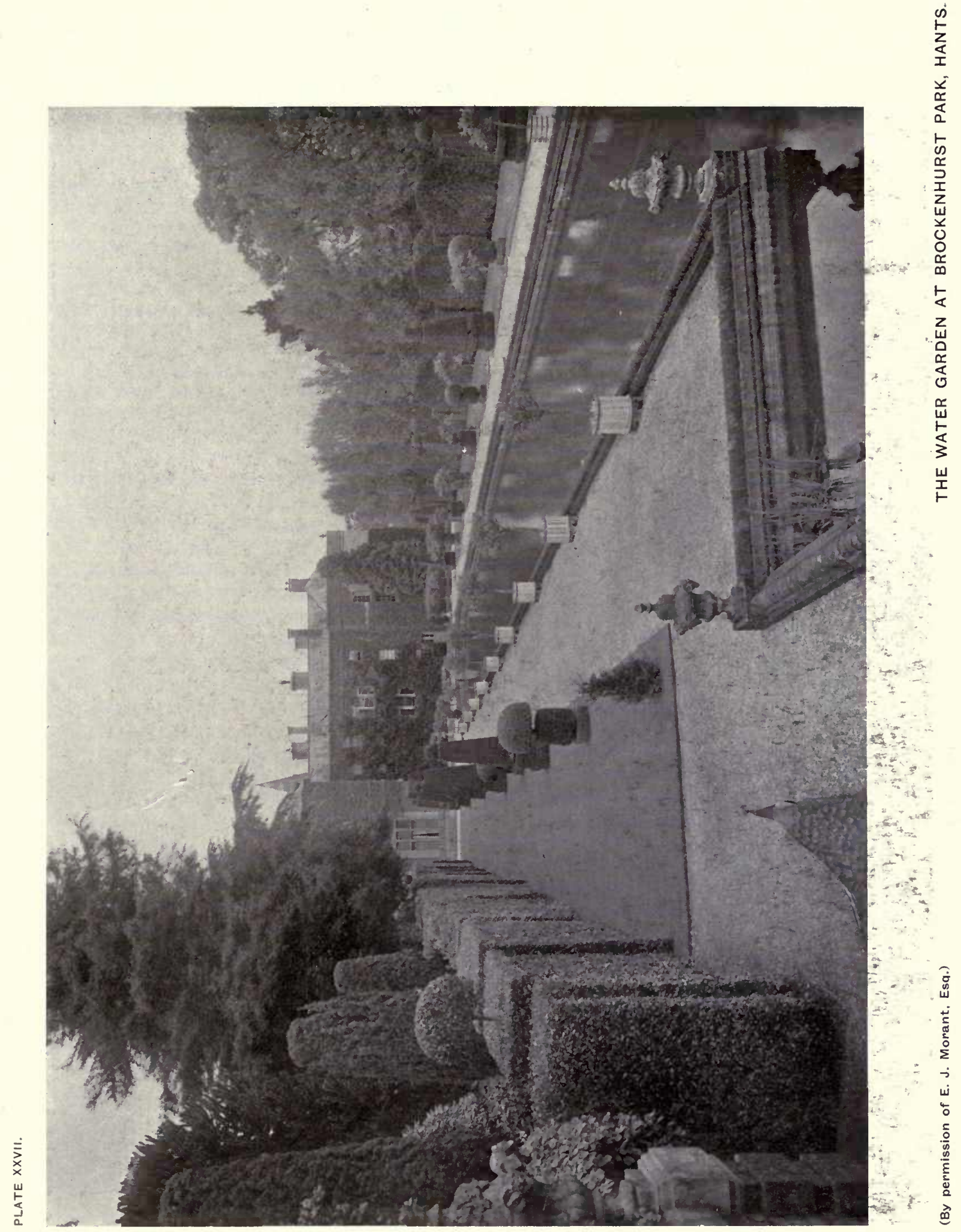




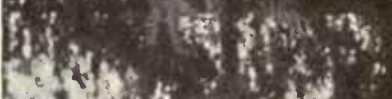

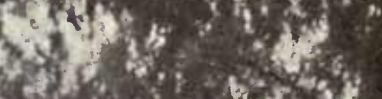

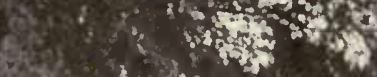

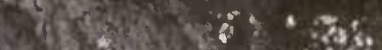

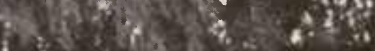
$x-2$

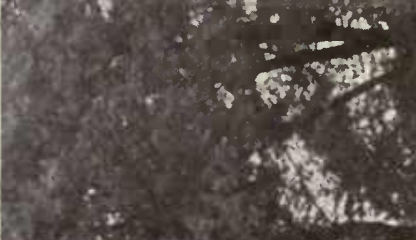

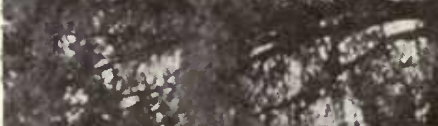

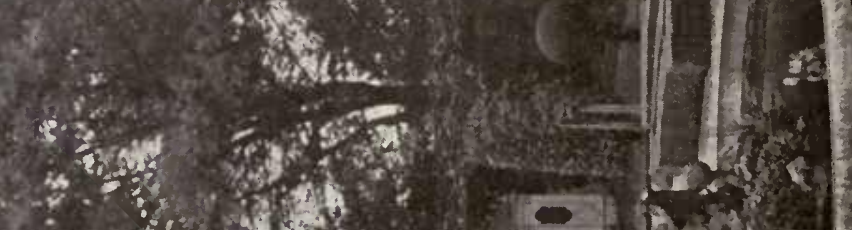

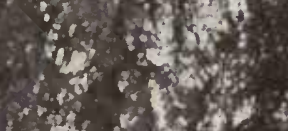

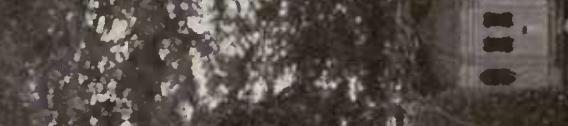

tond $0 x+103$

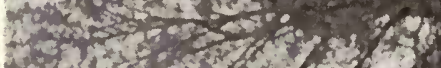

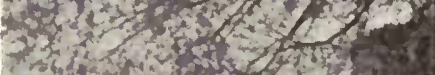

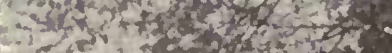

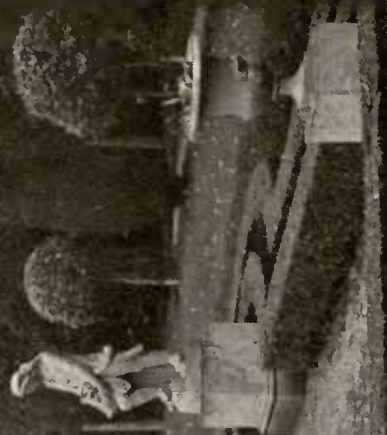




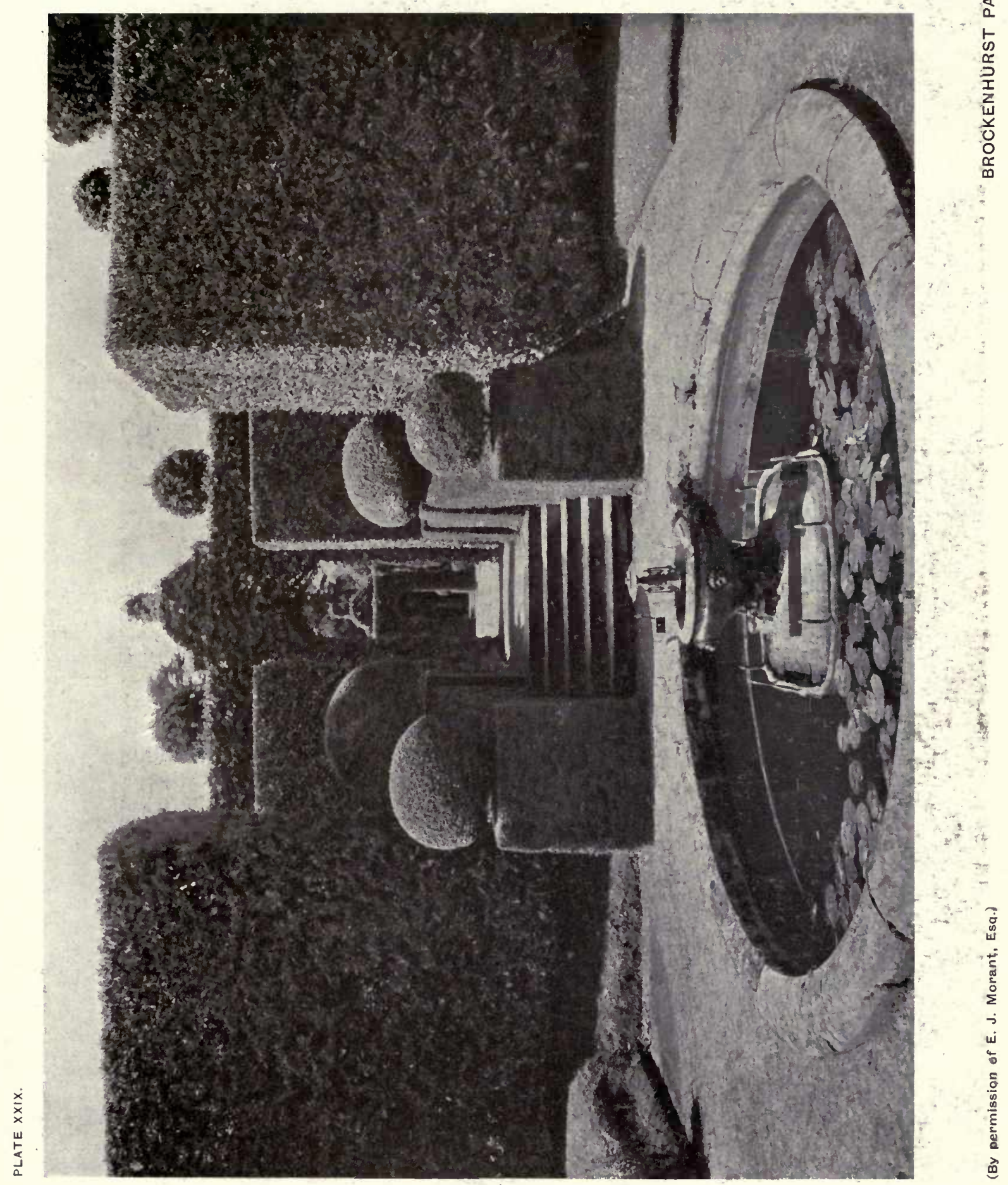




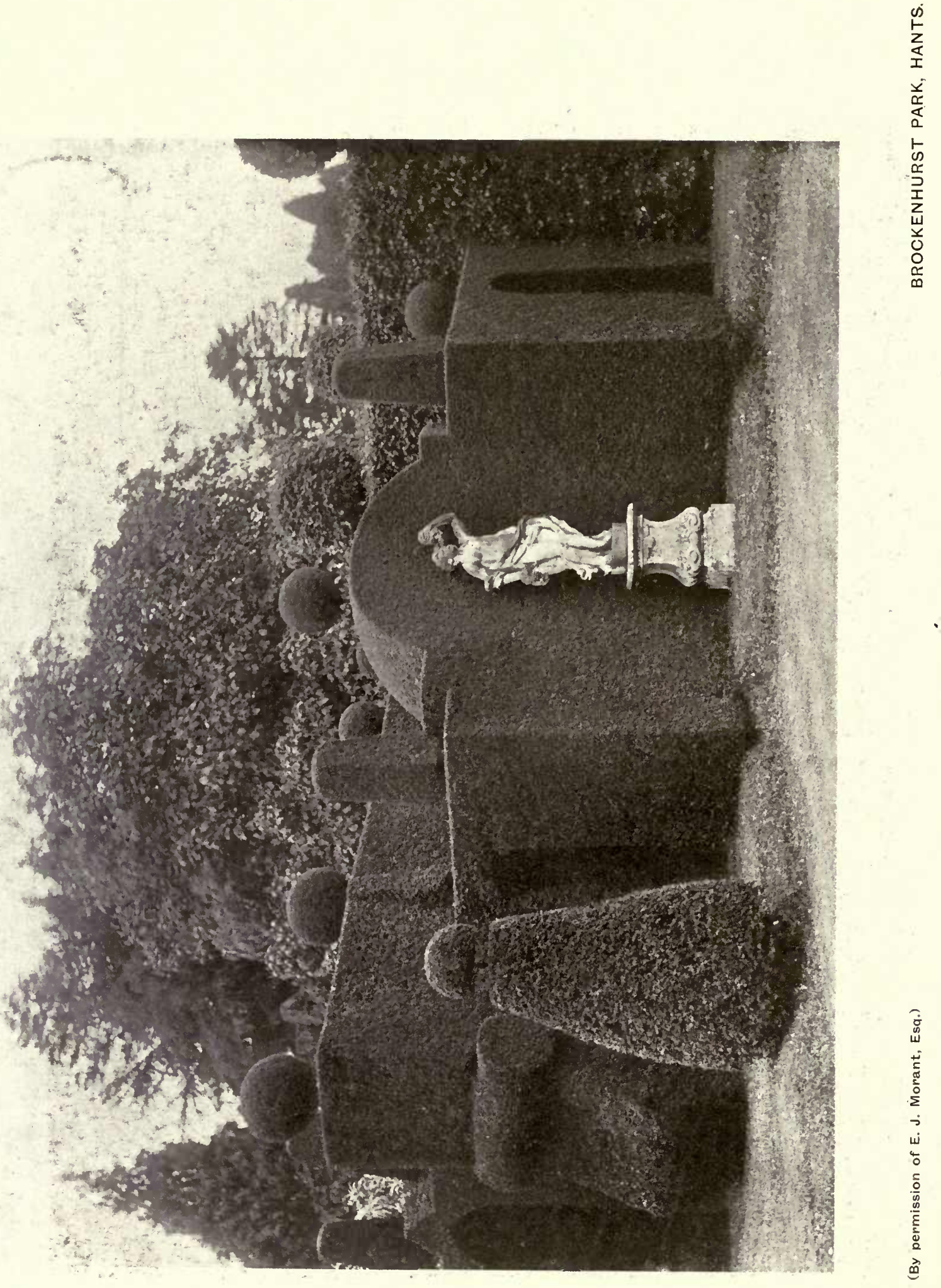




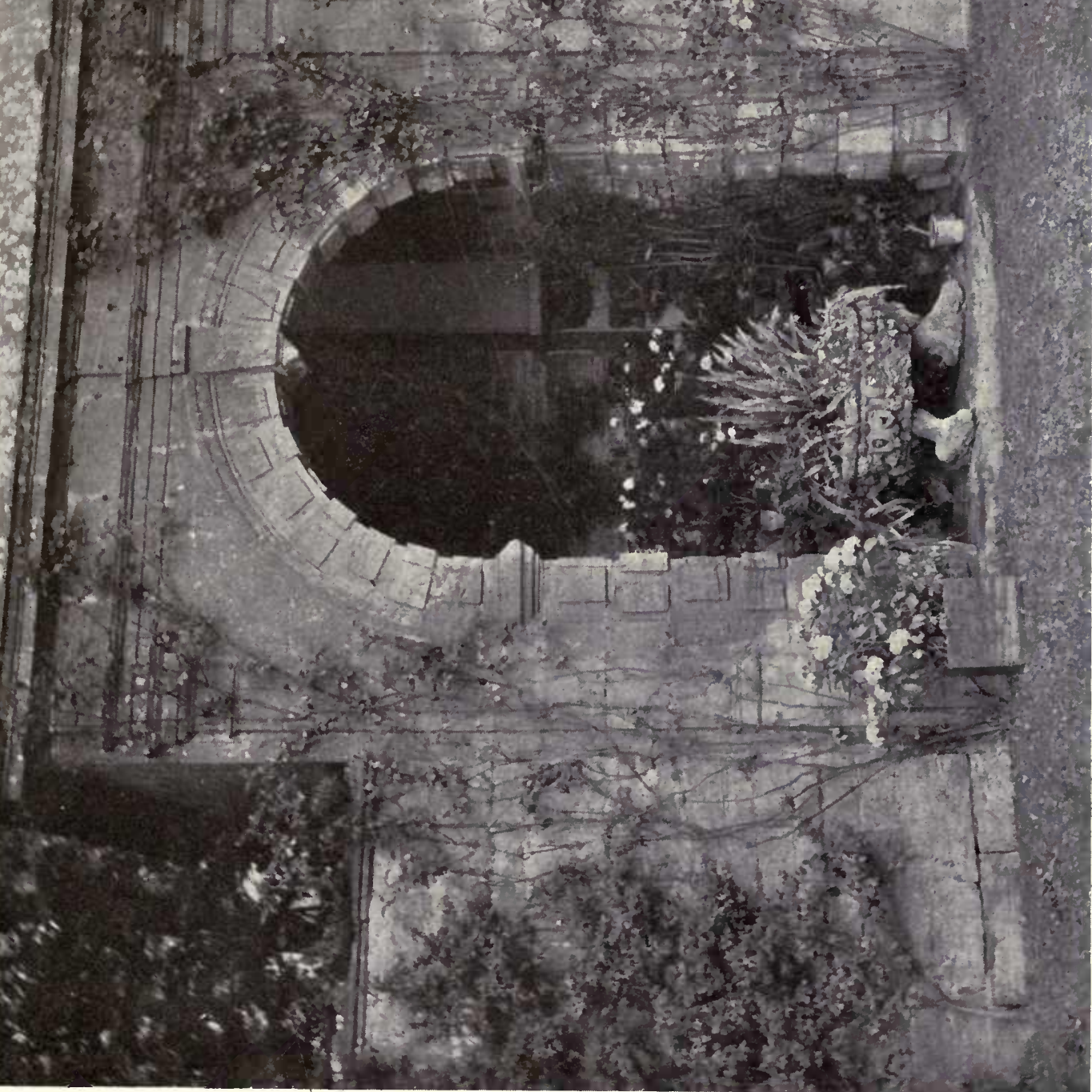




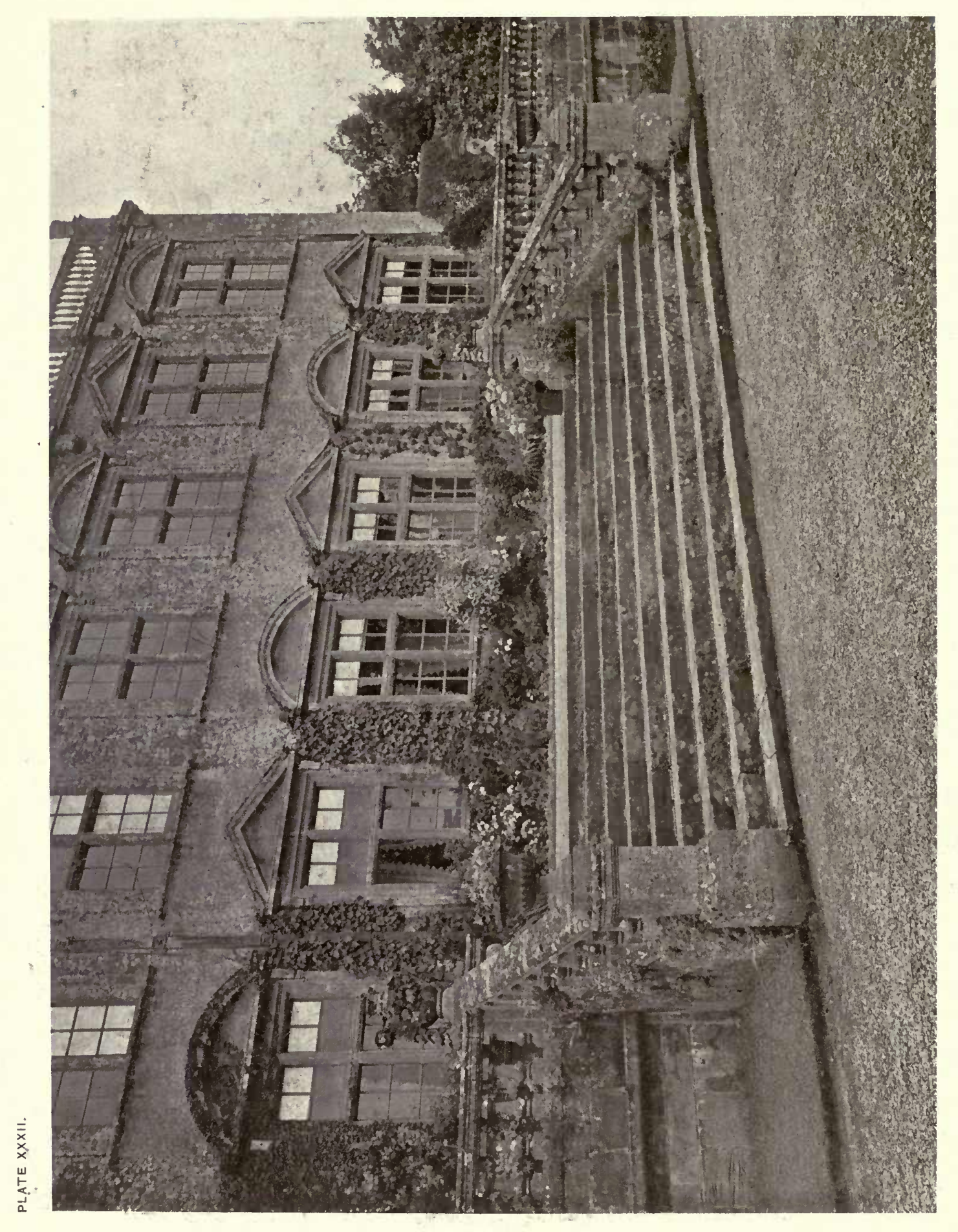

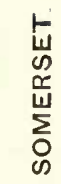

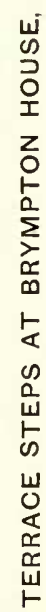

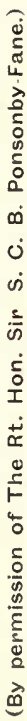




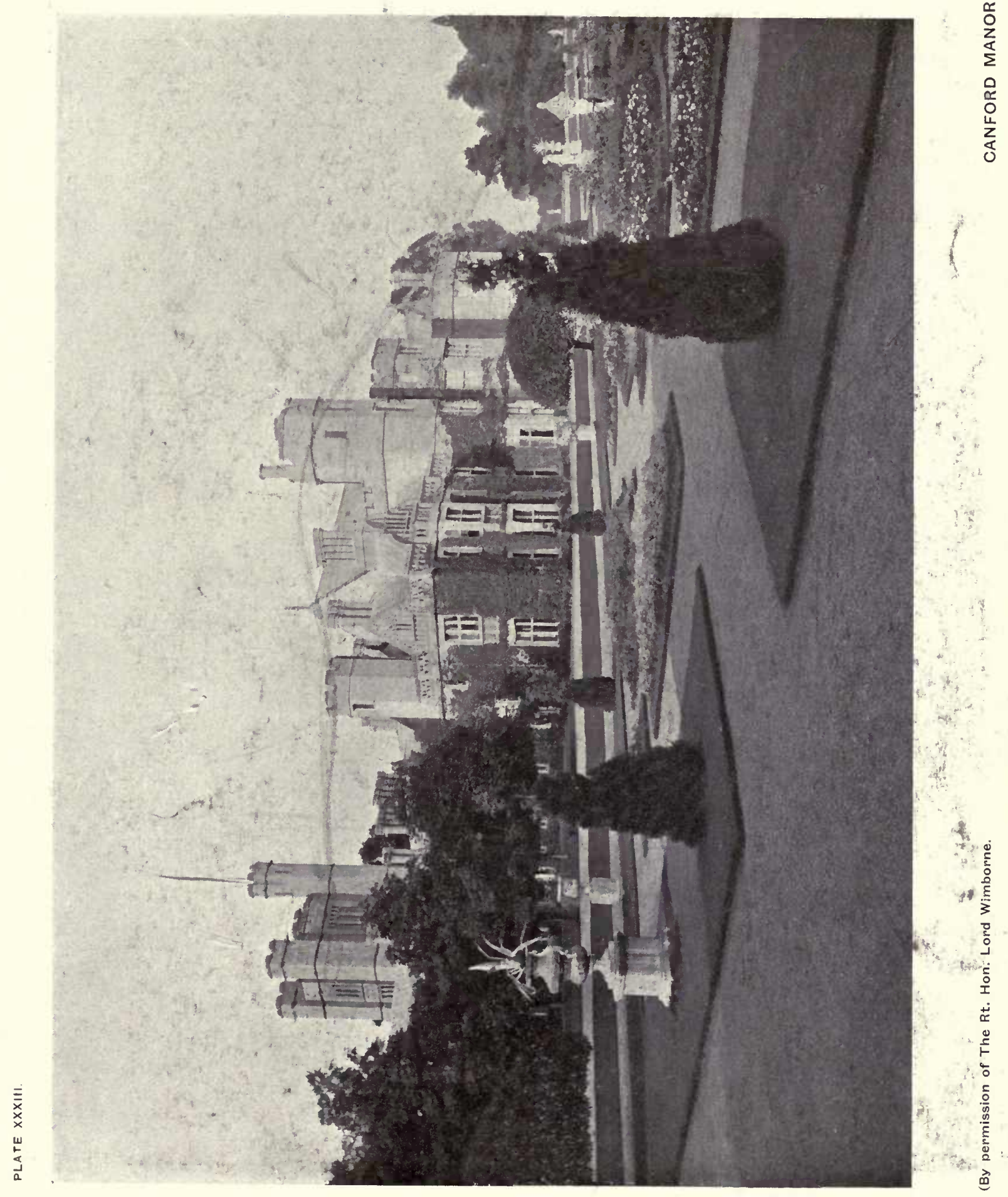




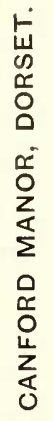

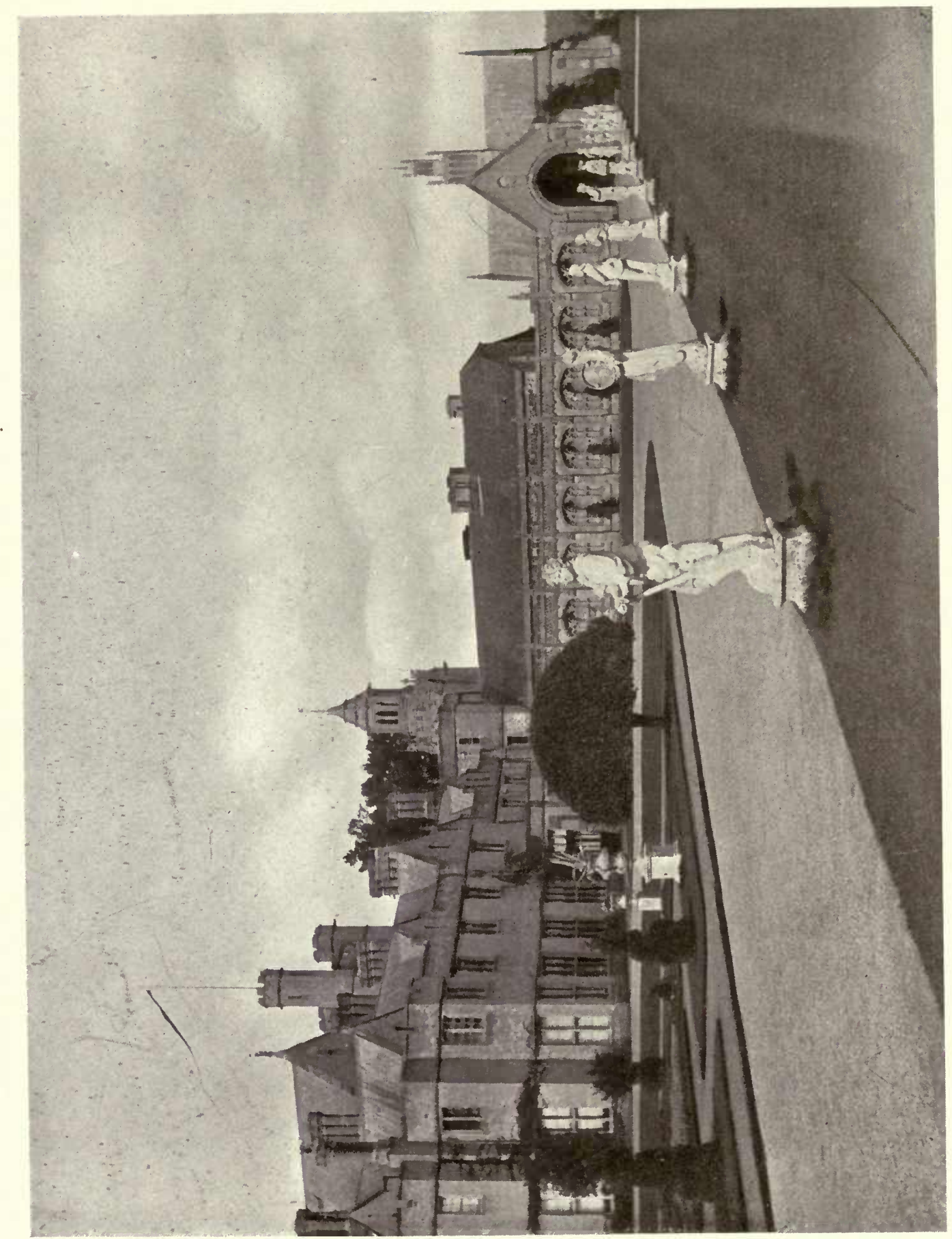




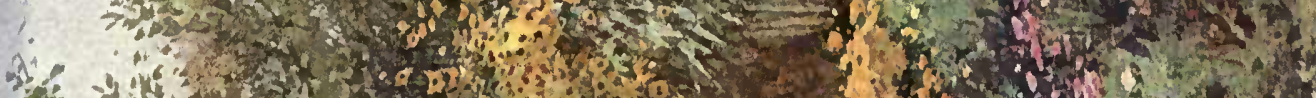

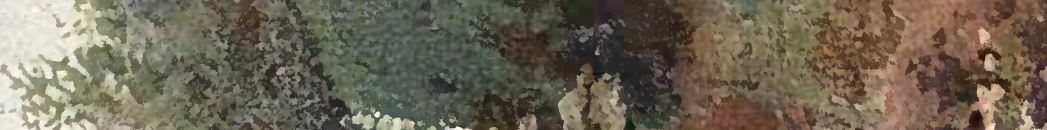

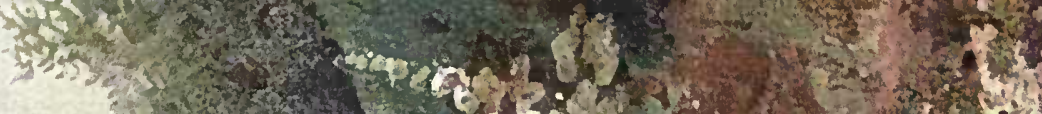

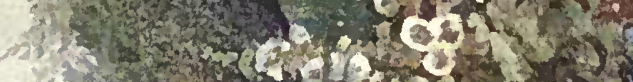

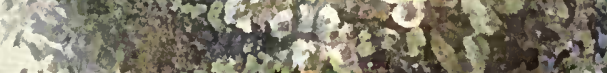

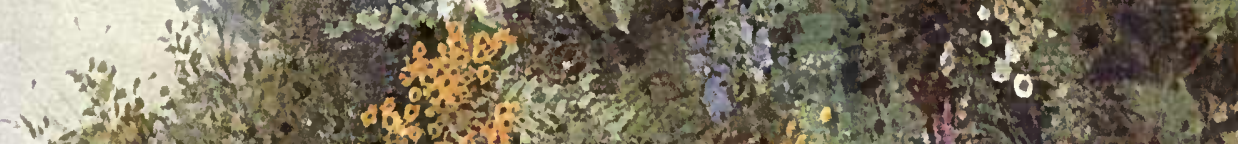

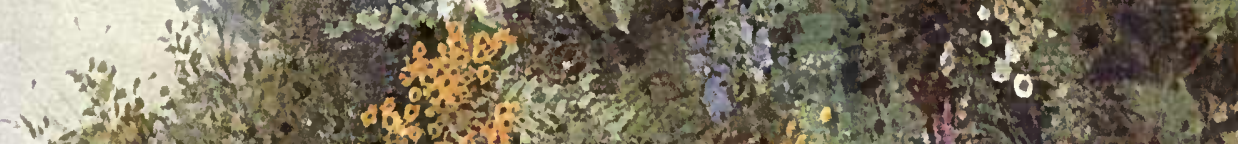

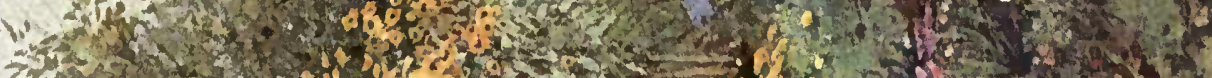

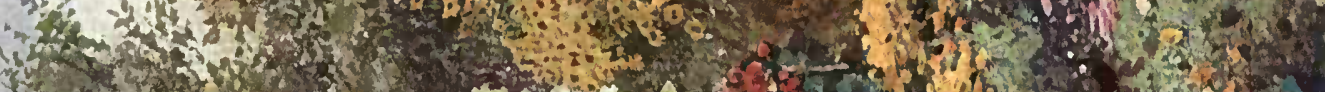

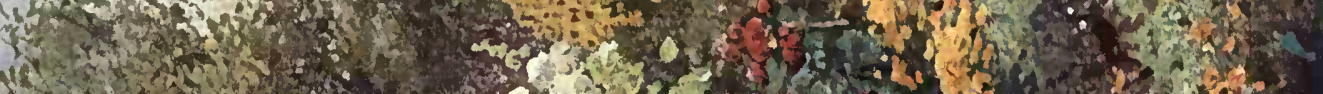

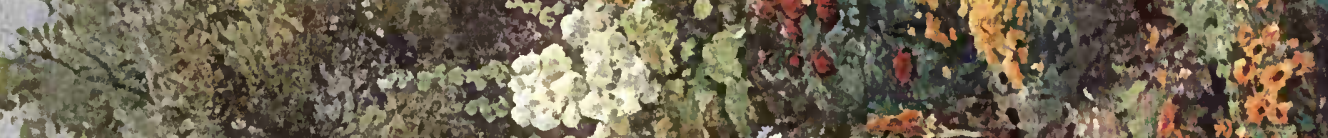
2.

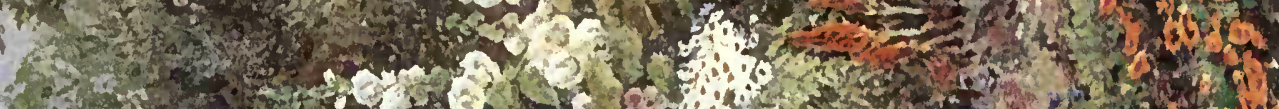

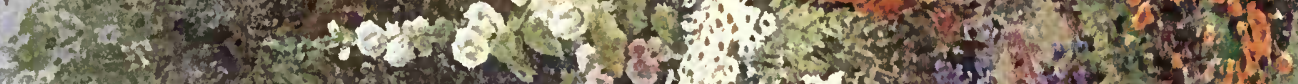

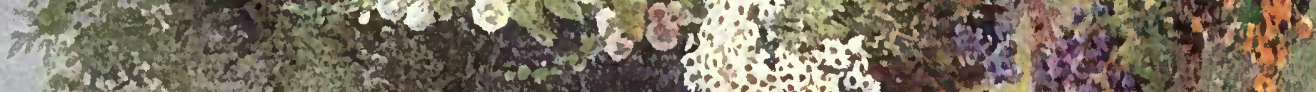
tor

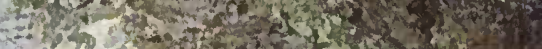

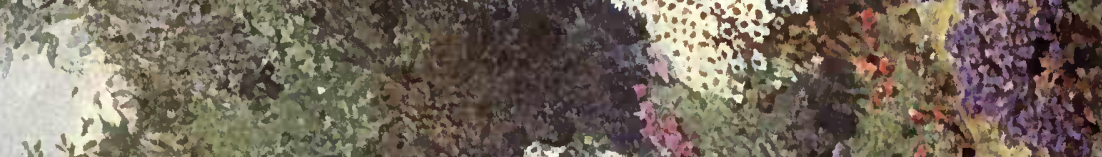

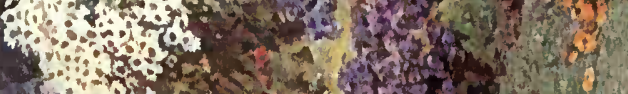
P.

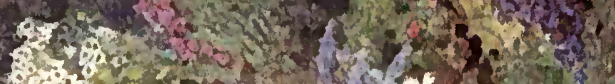

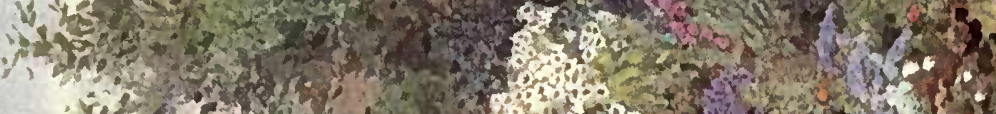

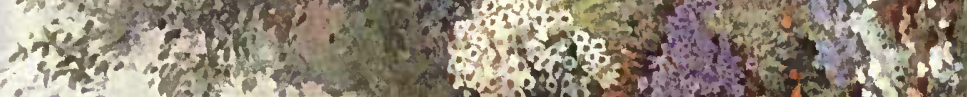

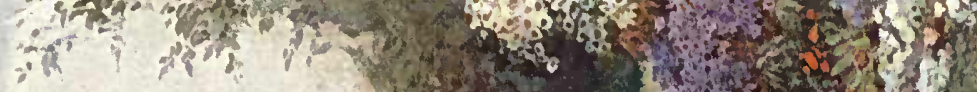

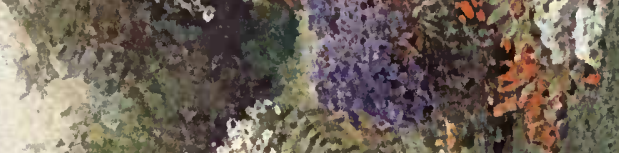

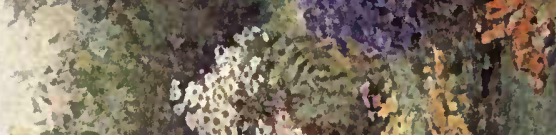

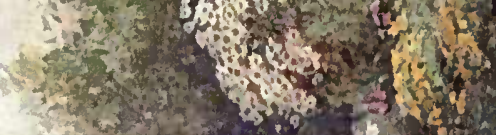

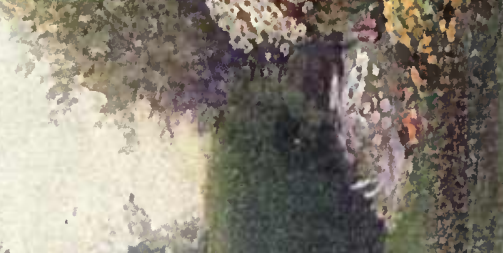

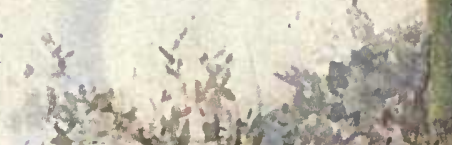

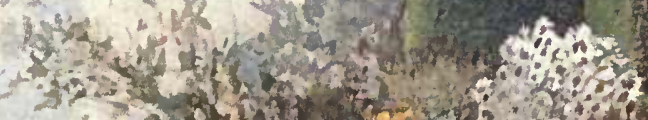

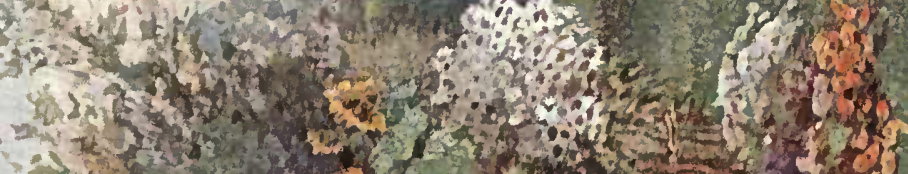

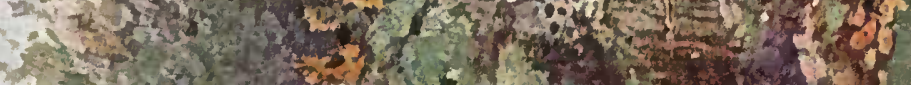




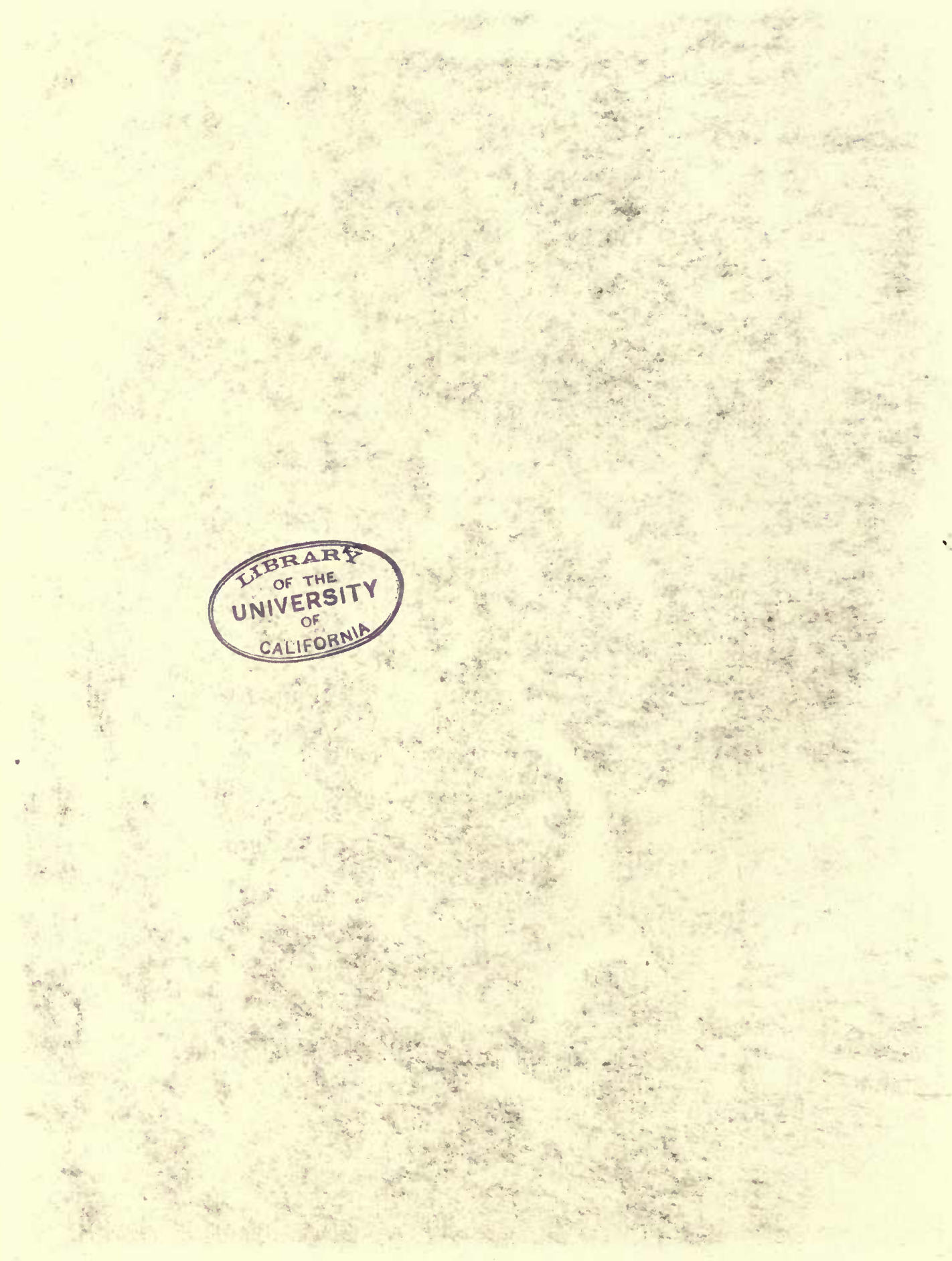




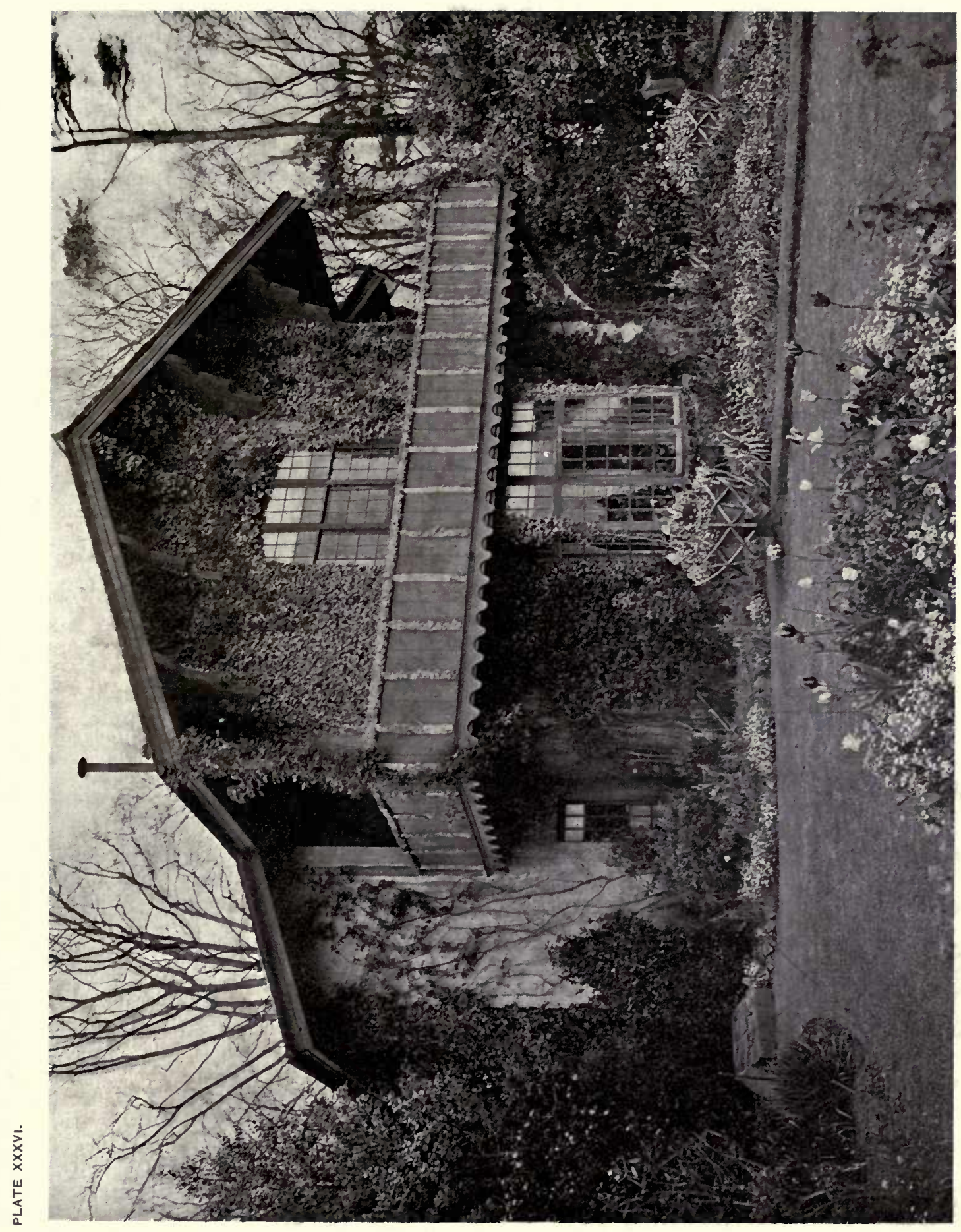

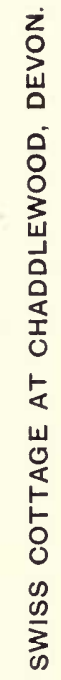




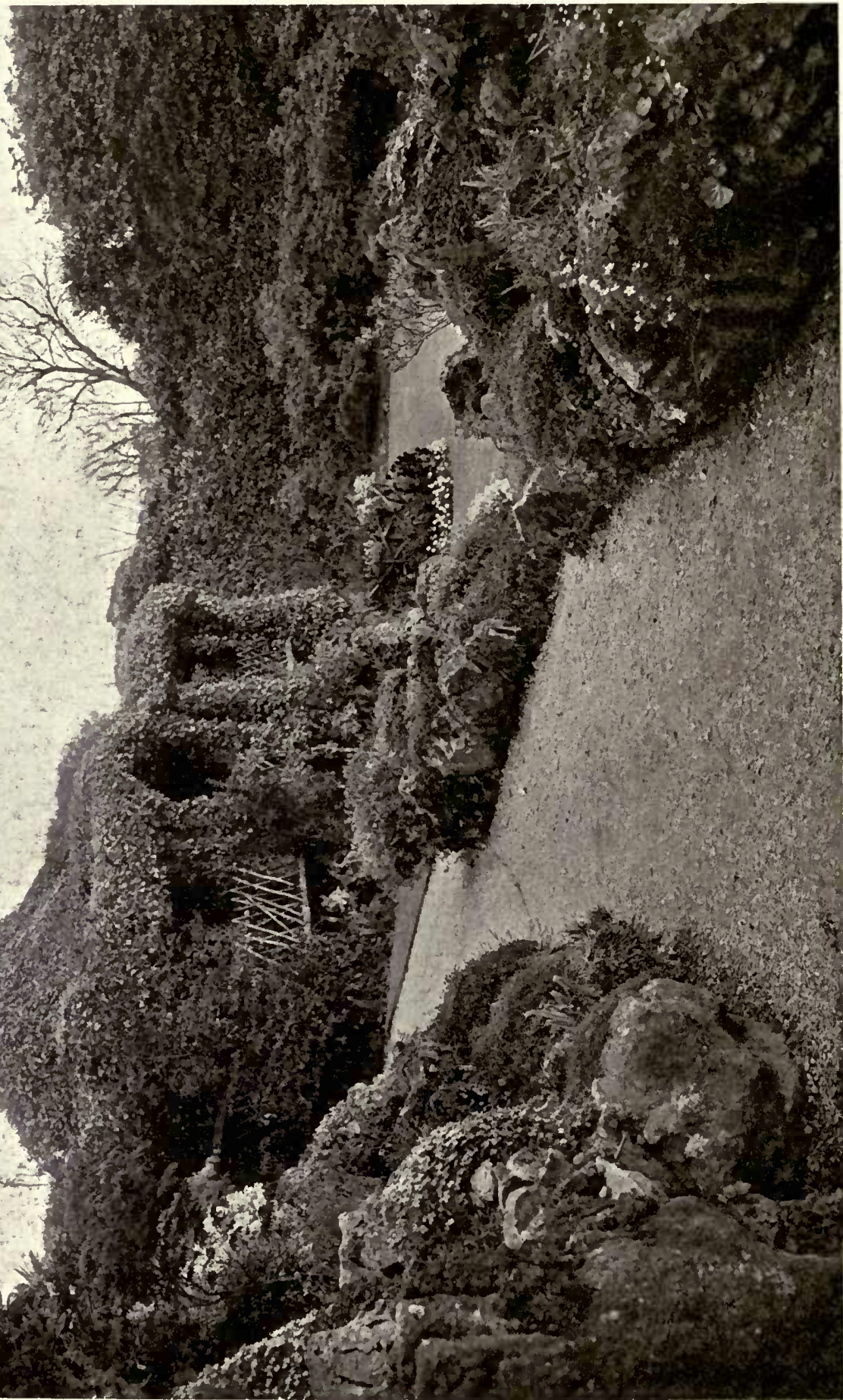




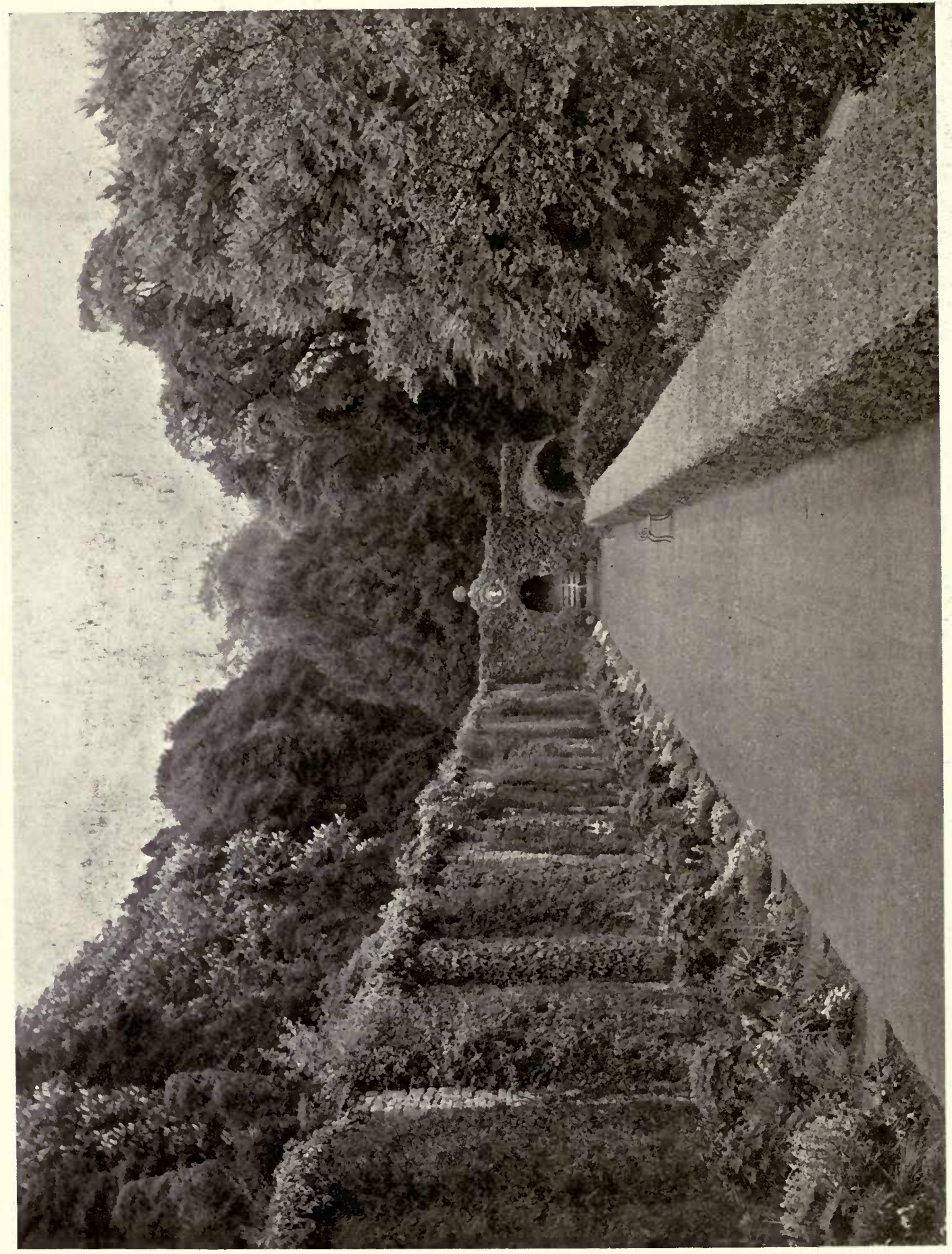

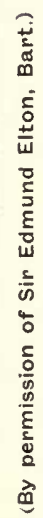




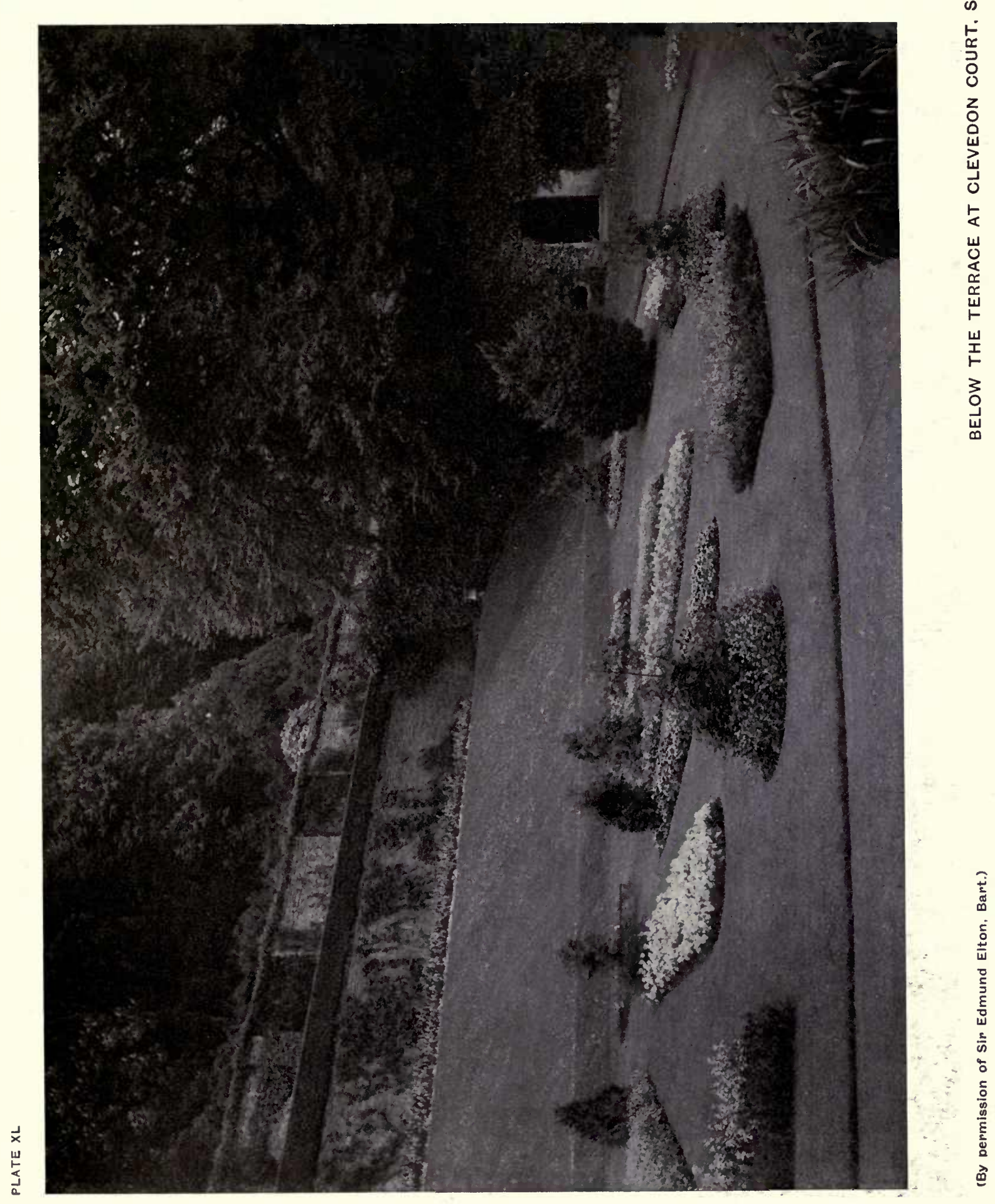




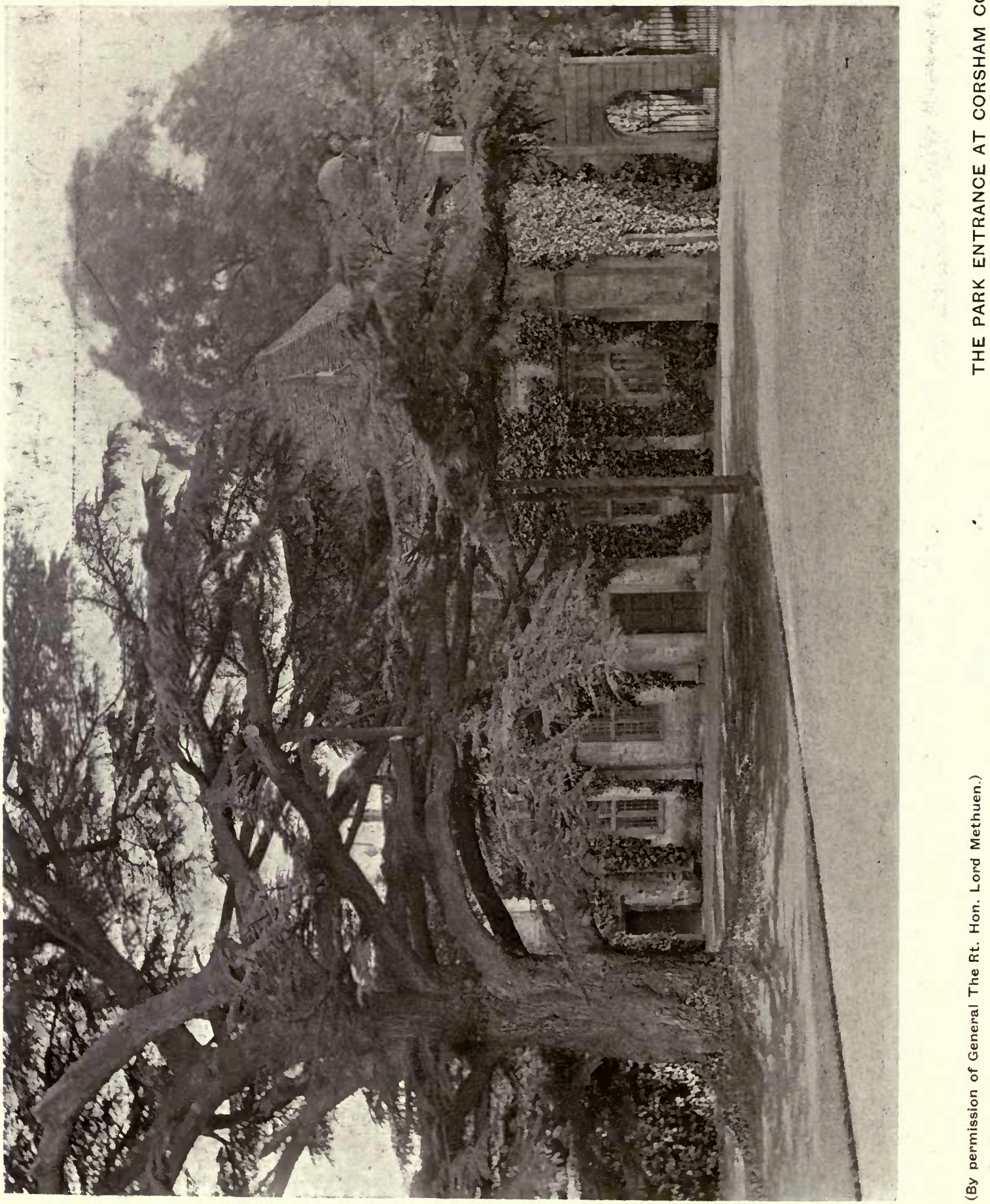




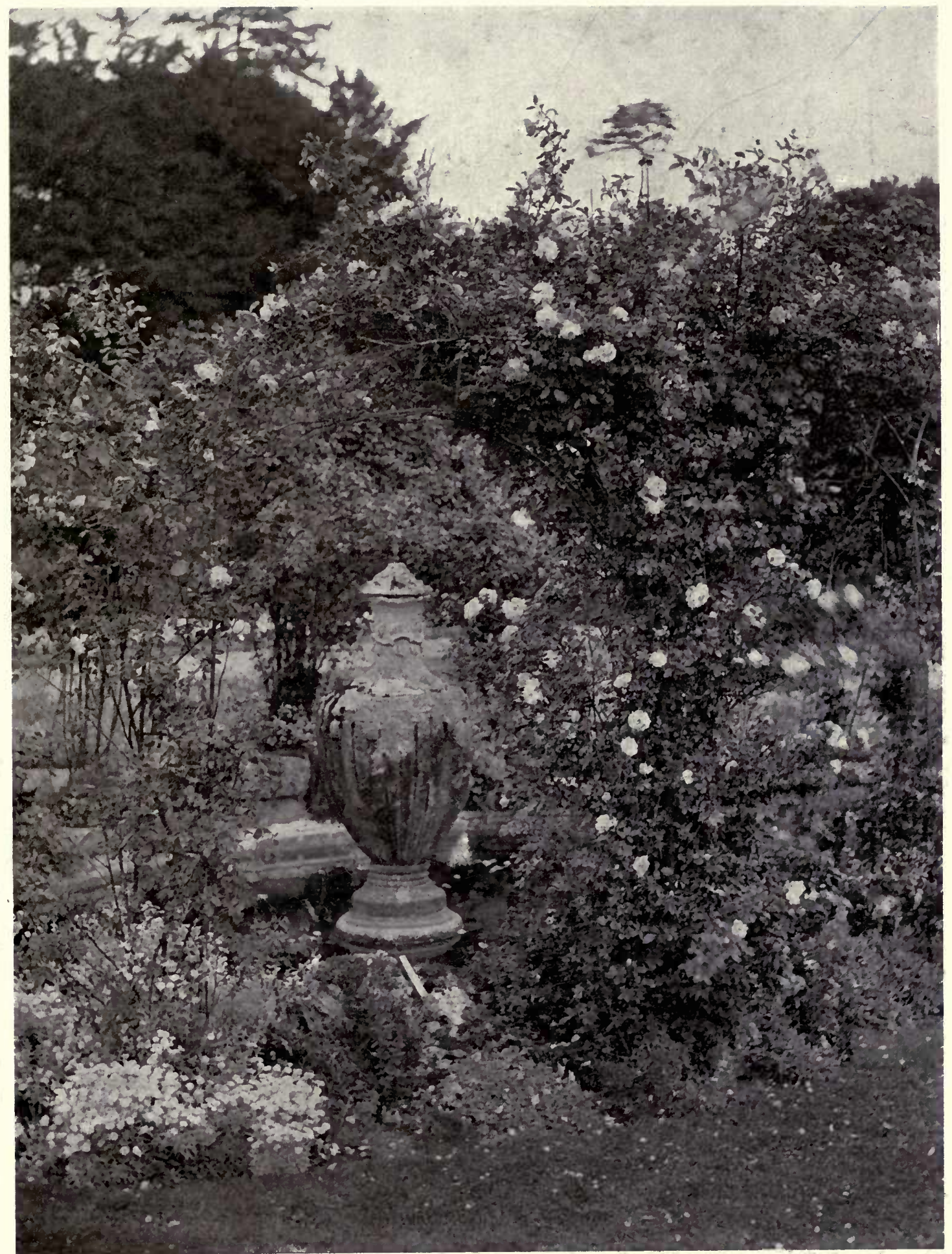




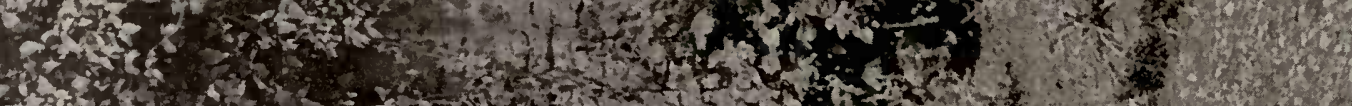

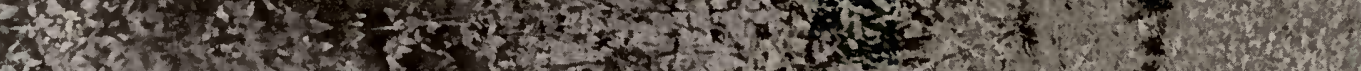

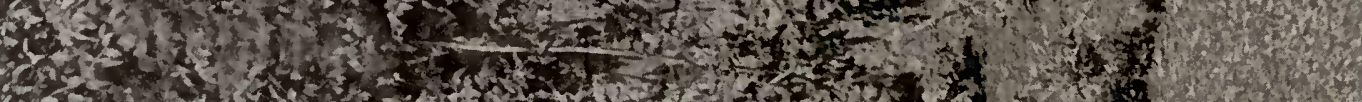

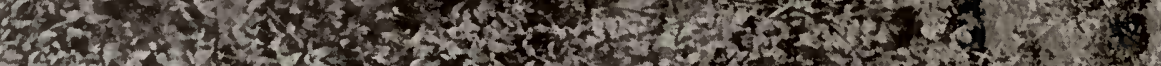

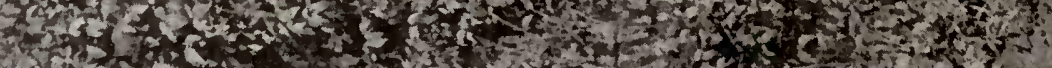

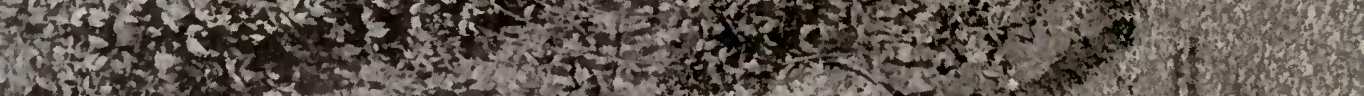

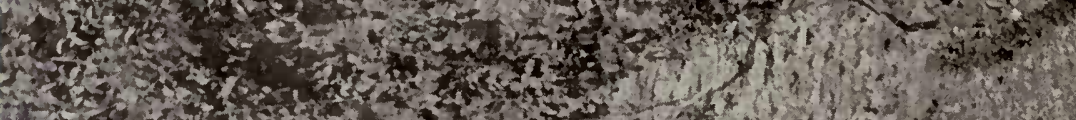

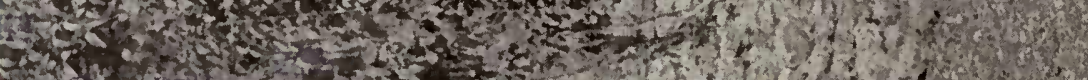

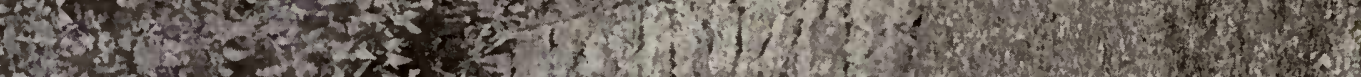

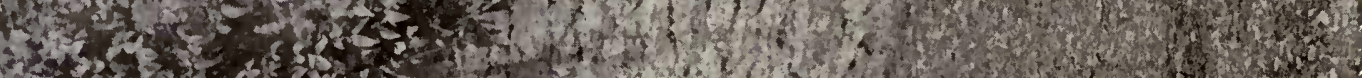

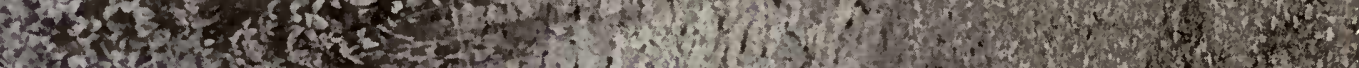

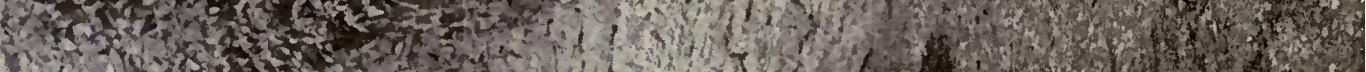

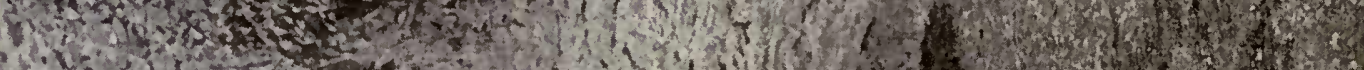

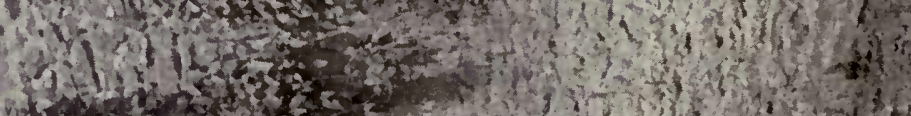

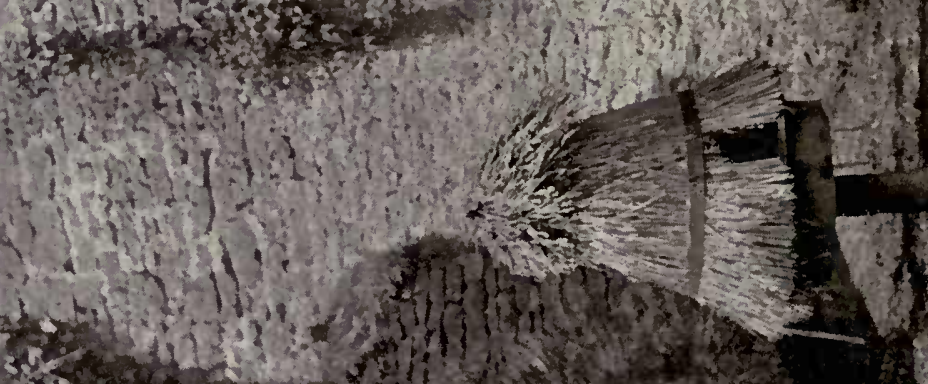

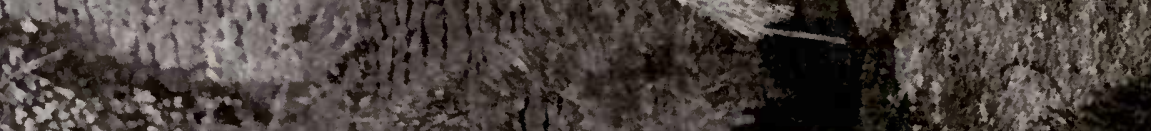
10 ( )

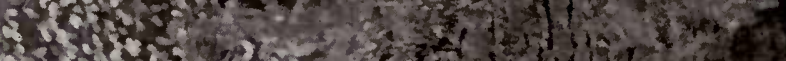

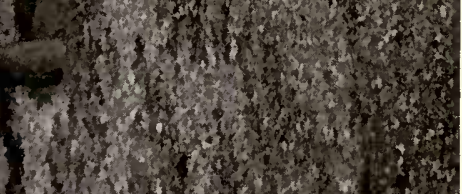

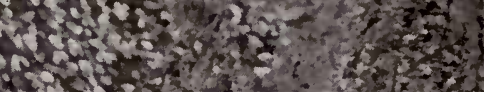
$4003 \times$,

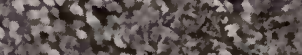
$x+20030$ 
3.

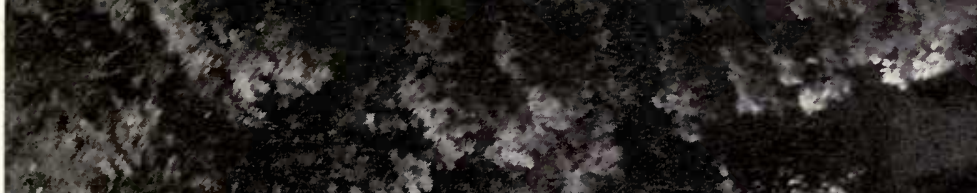

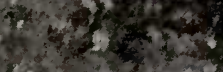

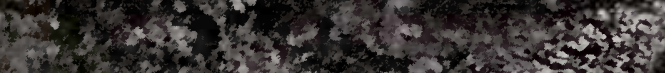

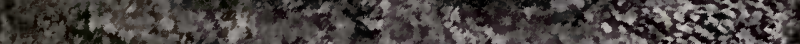

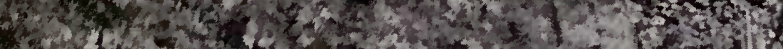

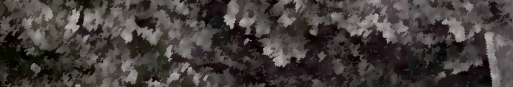

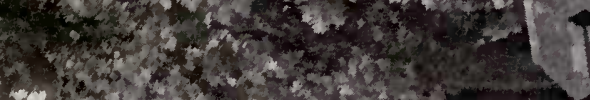

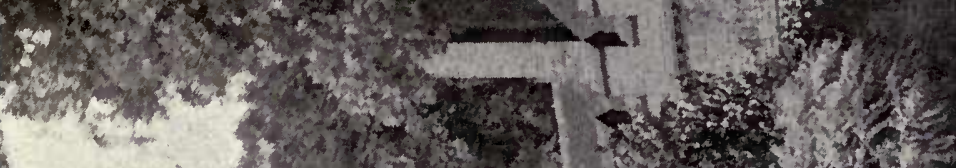

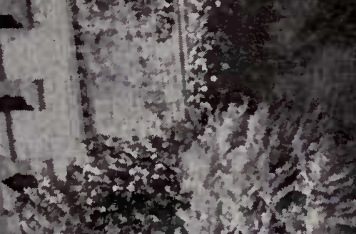

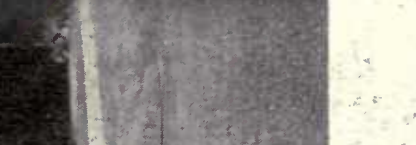

(is $w^{2}$
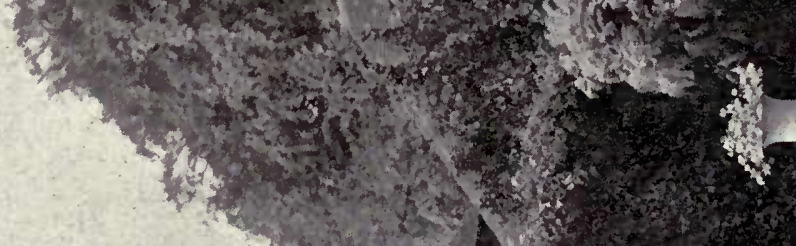

$+4 x^{2}+10$

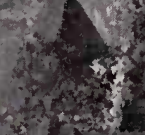

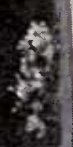

(x)

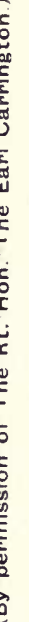




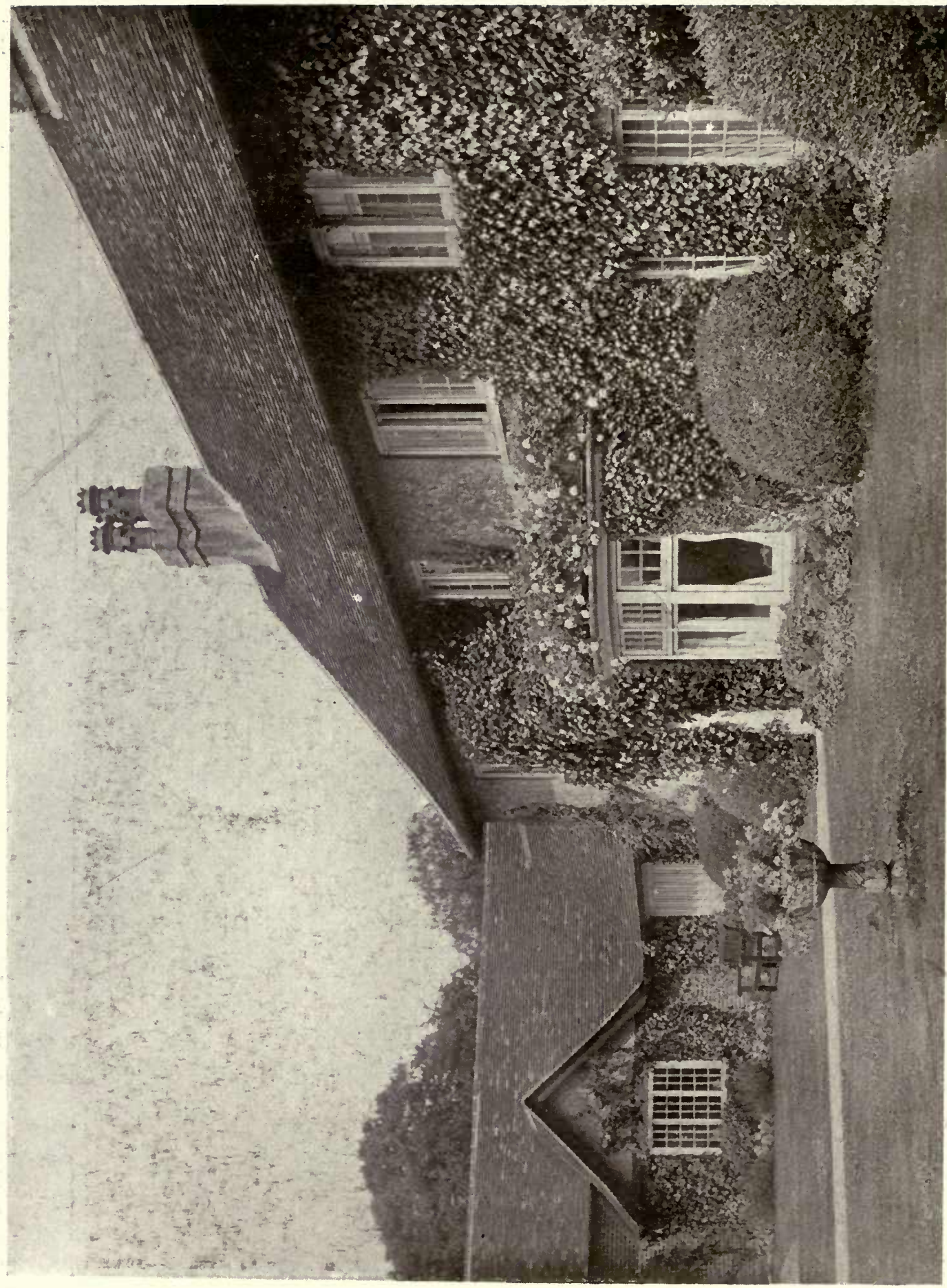




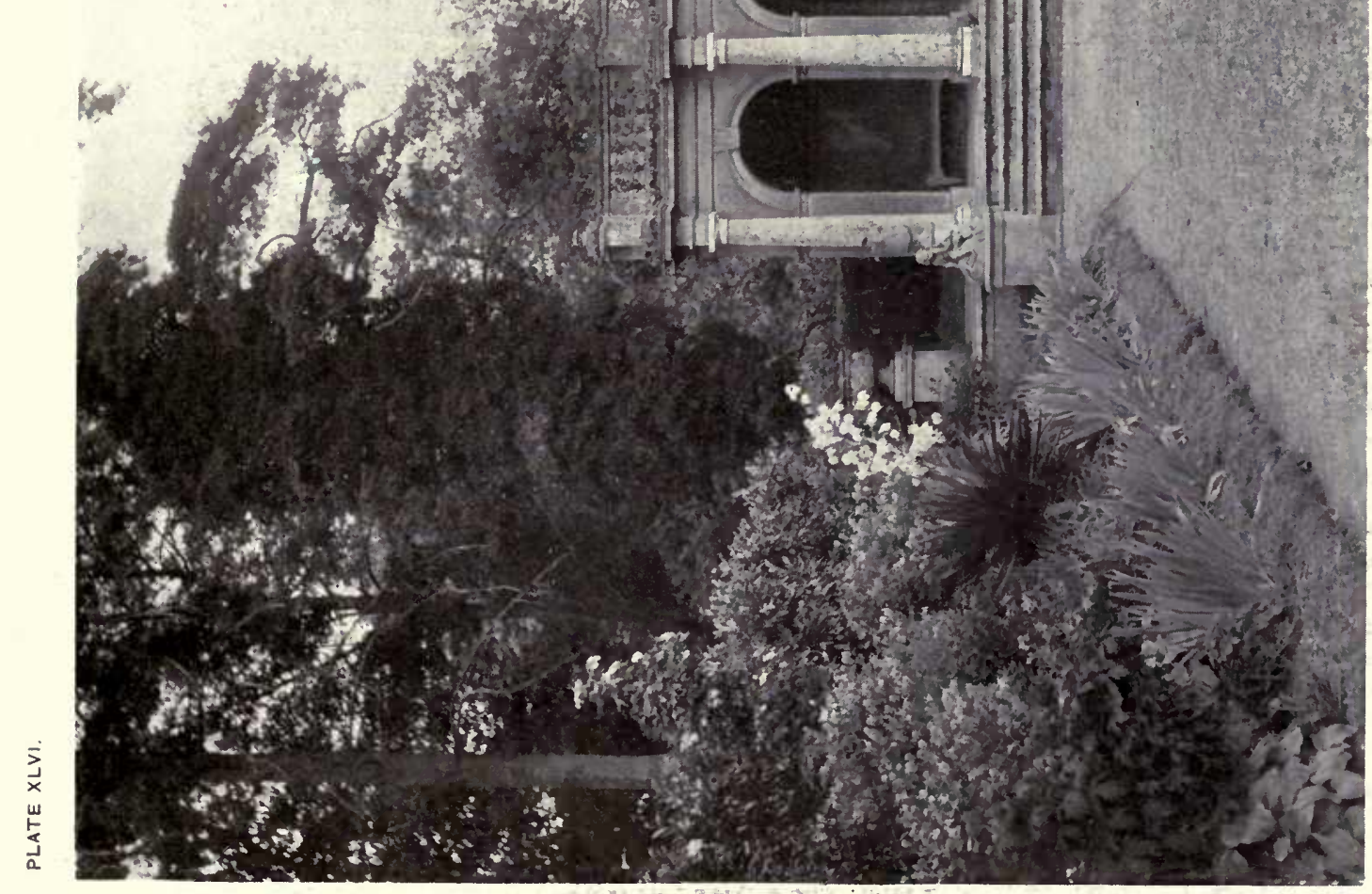




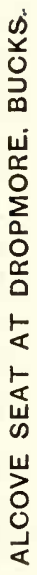

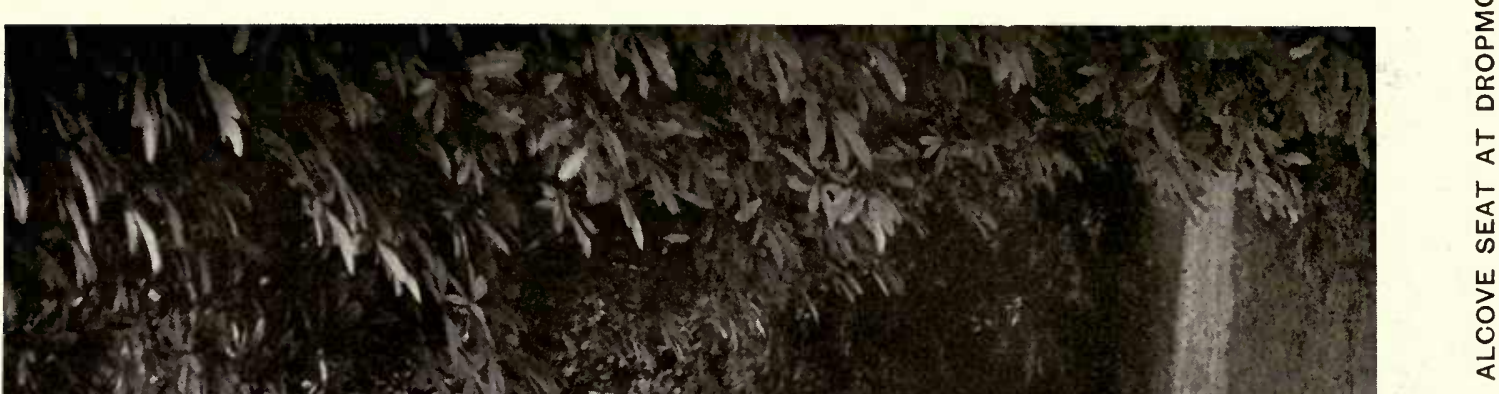

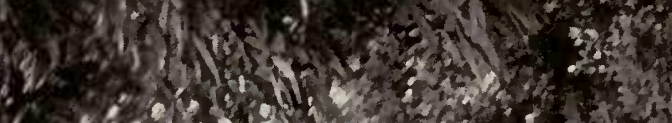

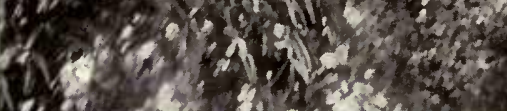

3t

64 .

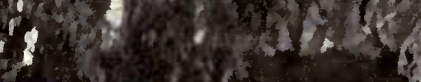

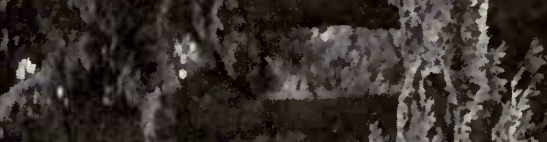

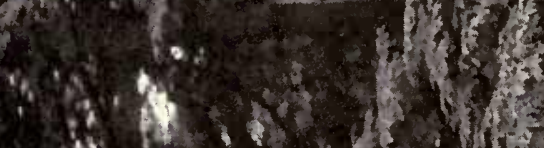

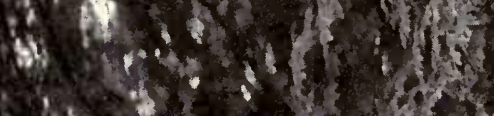

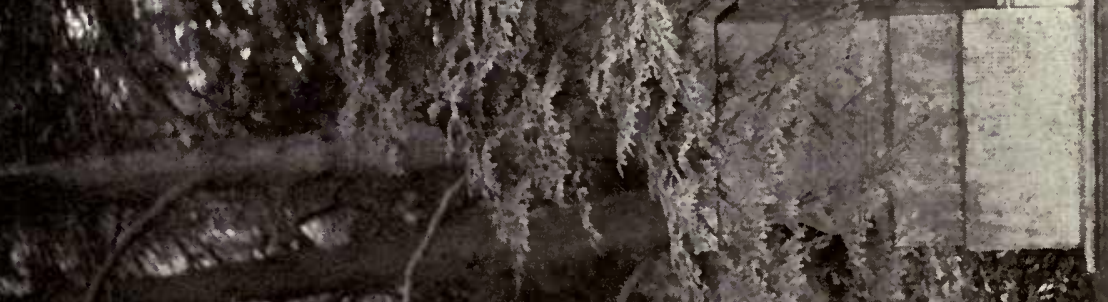

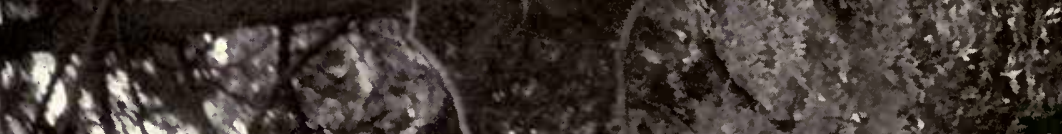

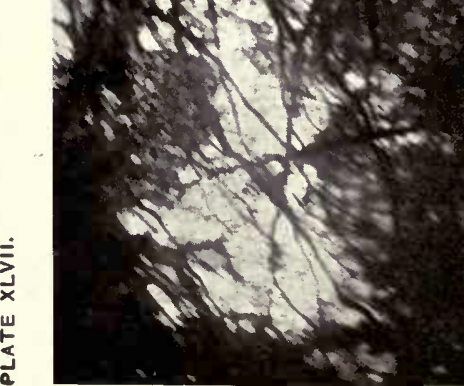

$x^{2}+x^{2}=$

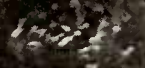

tan:

25

.

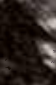




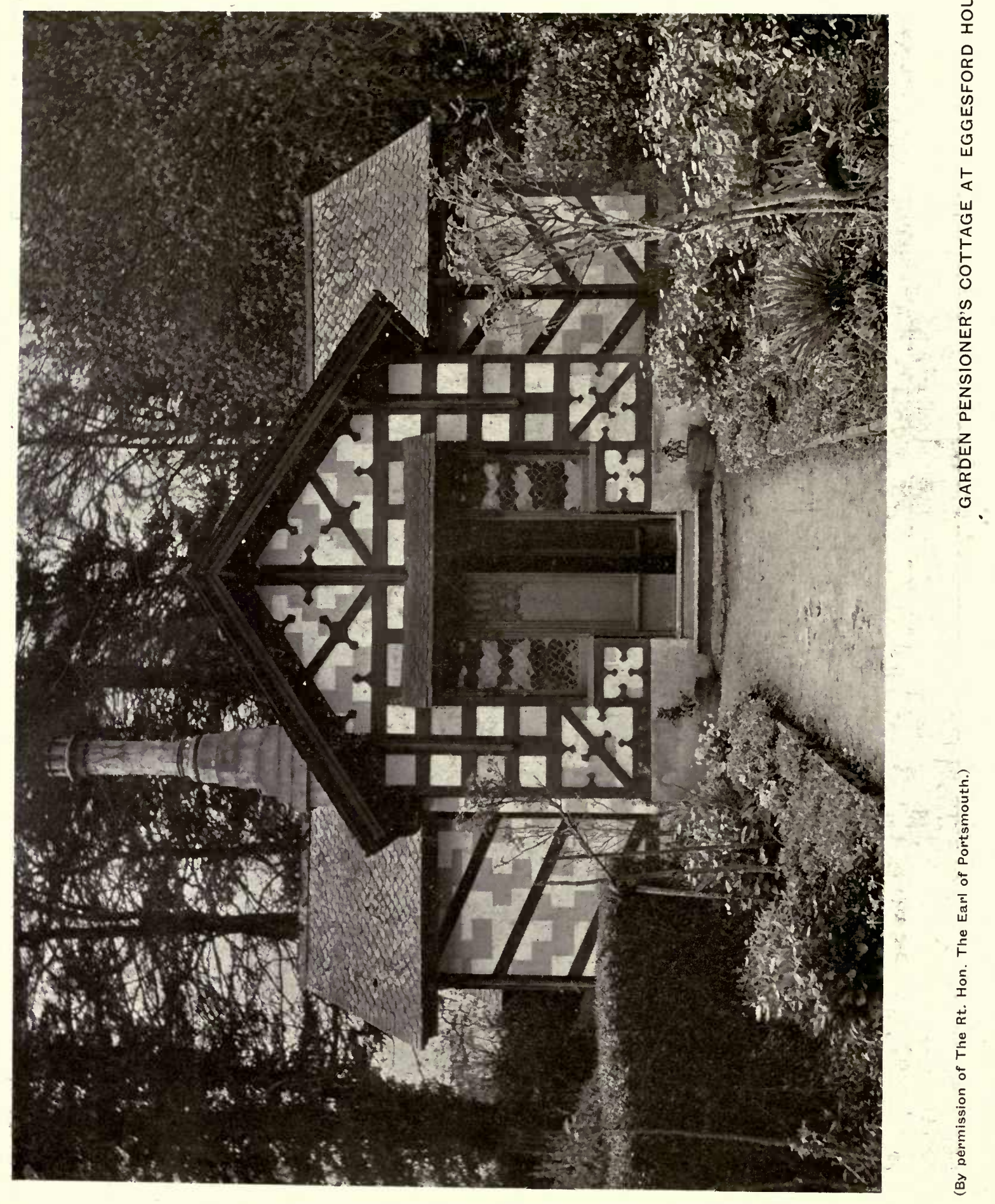




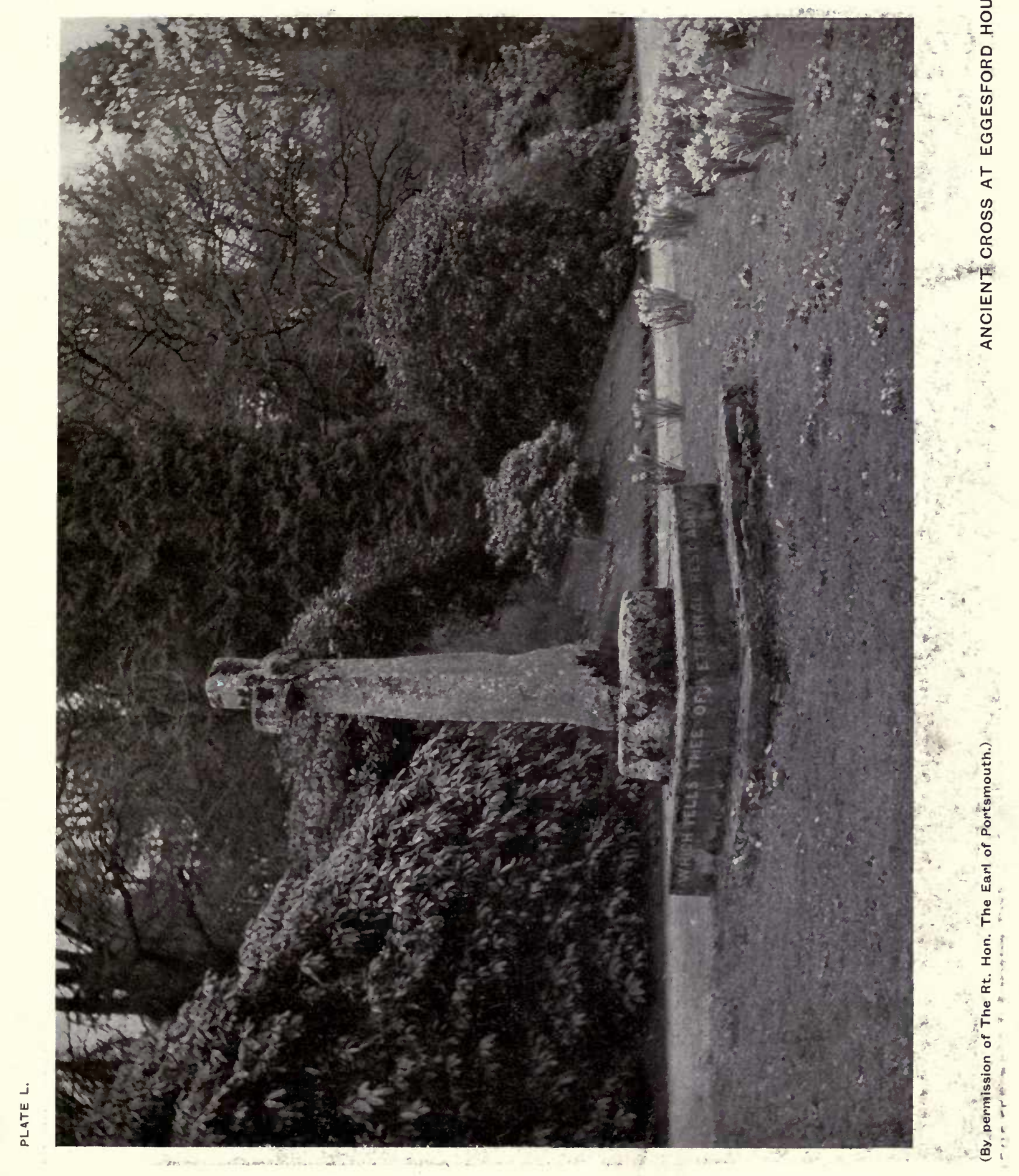




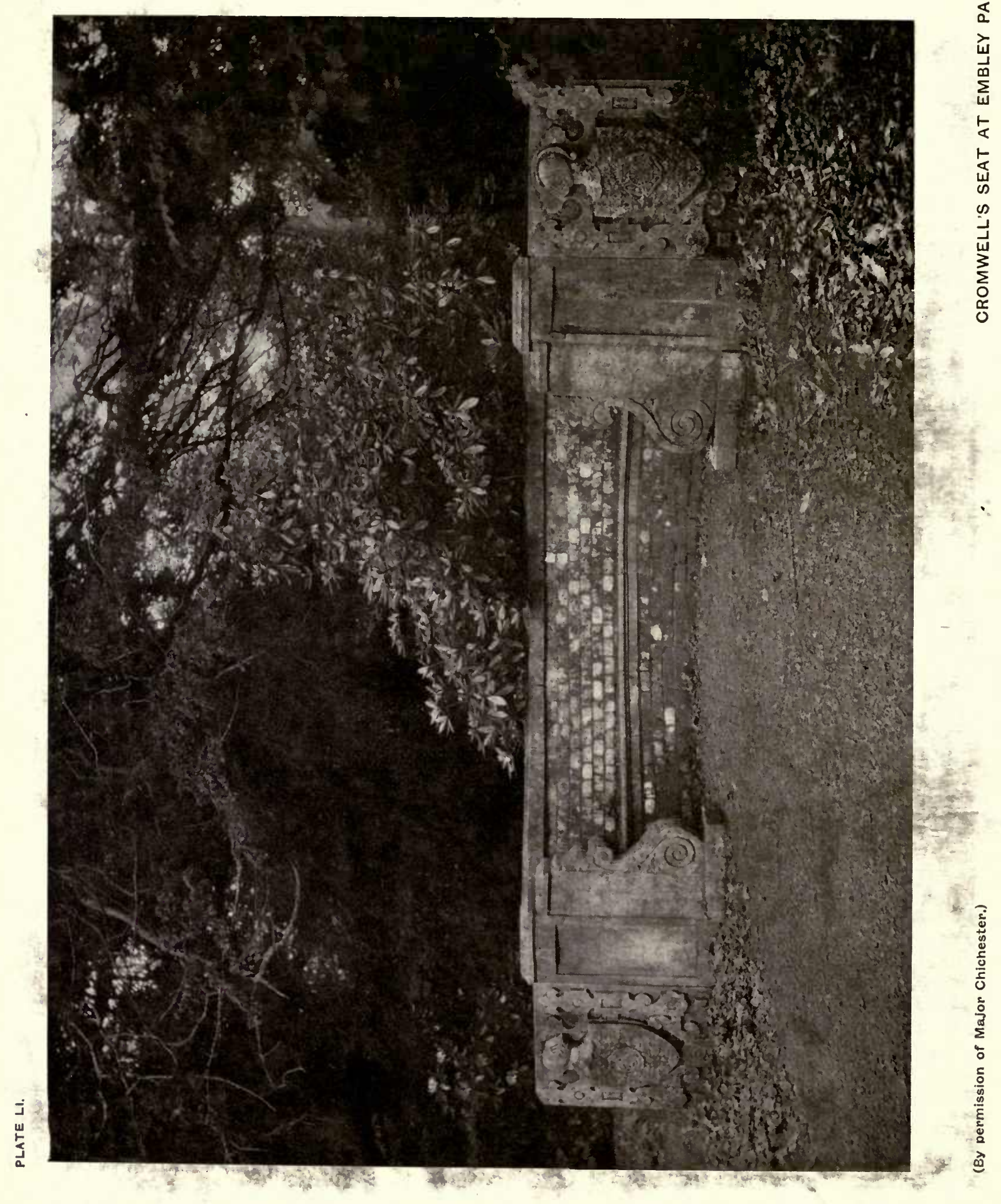




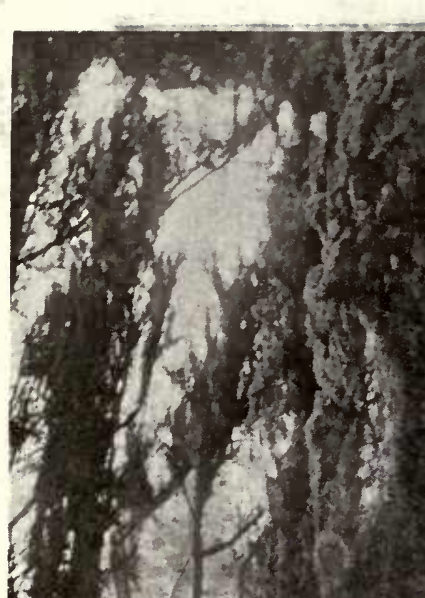

ti.

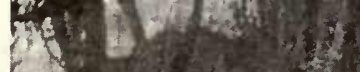

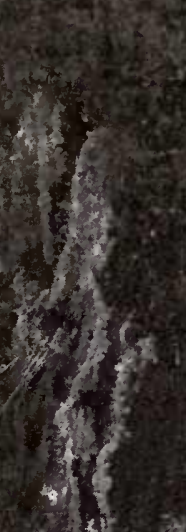

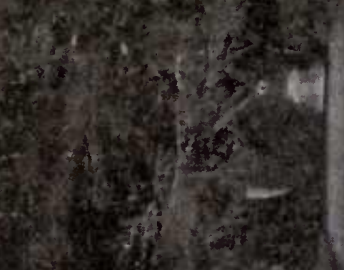

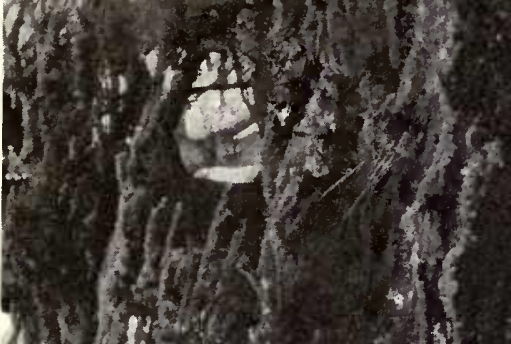

10. 6

in:

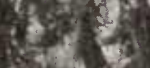

as

8. $(40$ की

$810 \%$

18

ing?

?.

4)
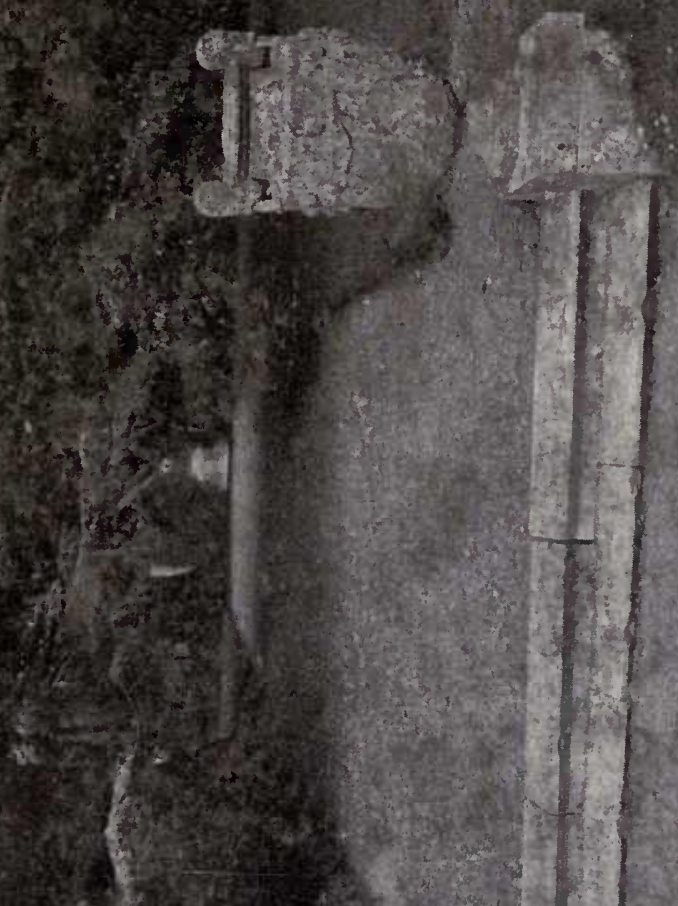


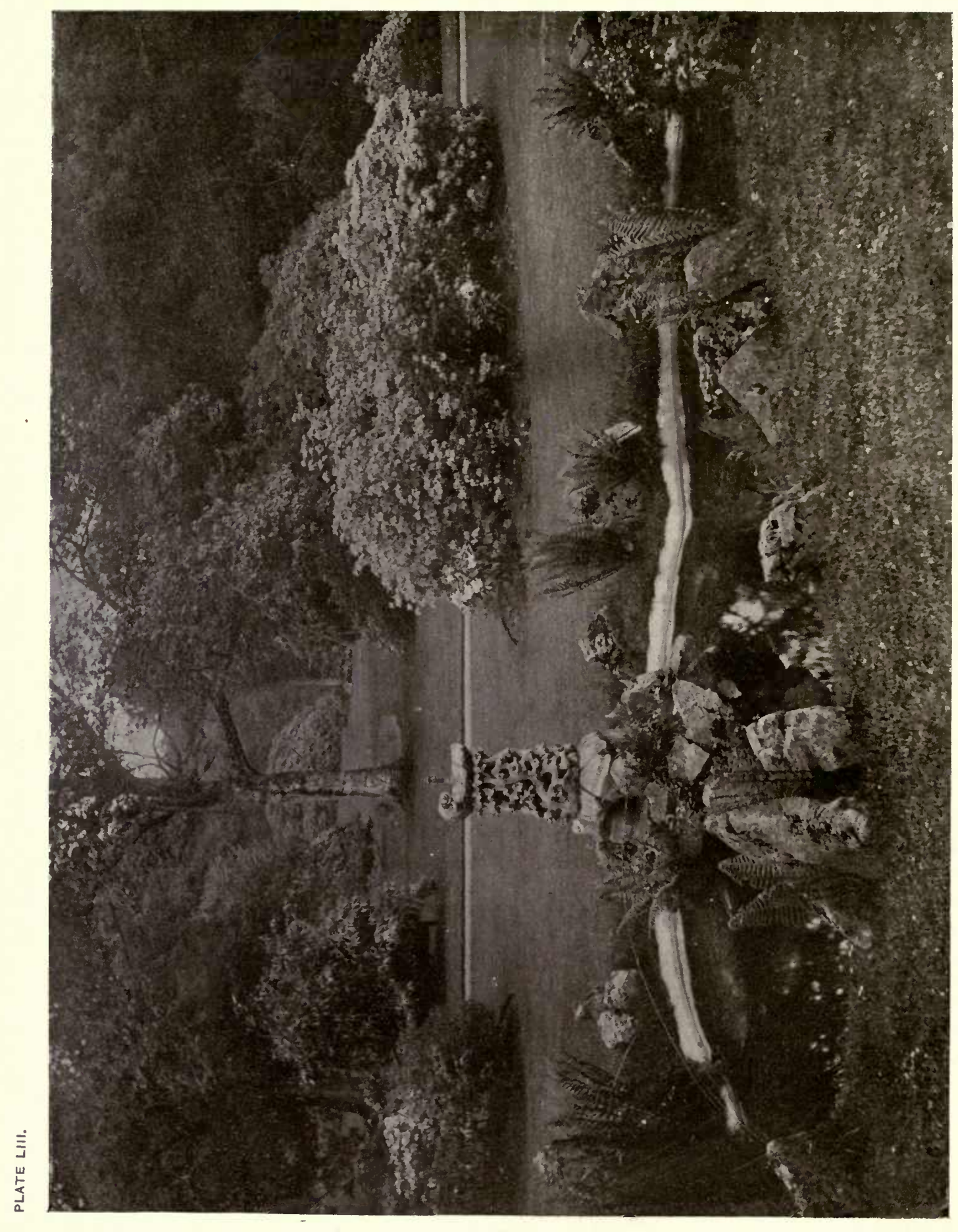

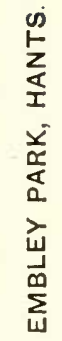


2arasys

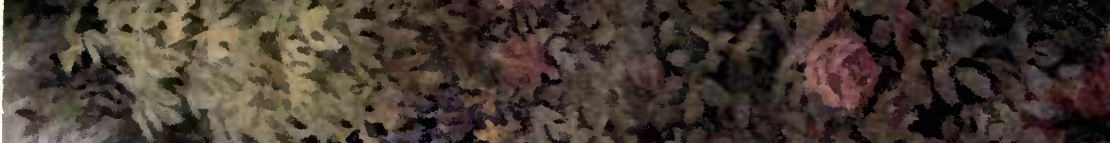

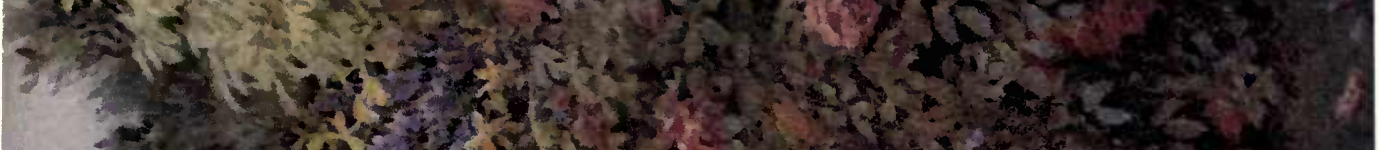

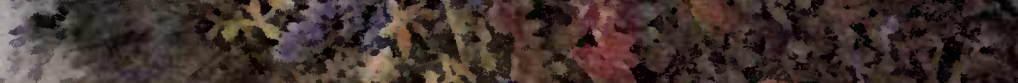

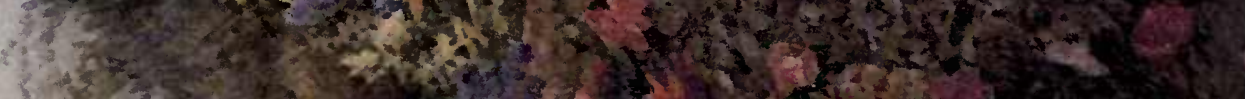

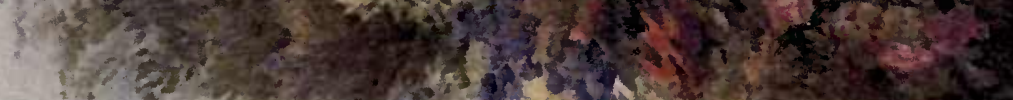

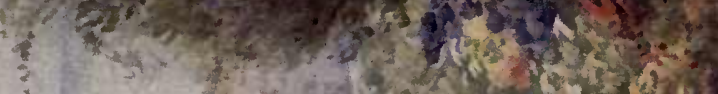

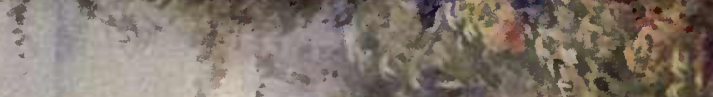
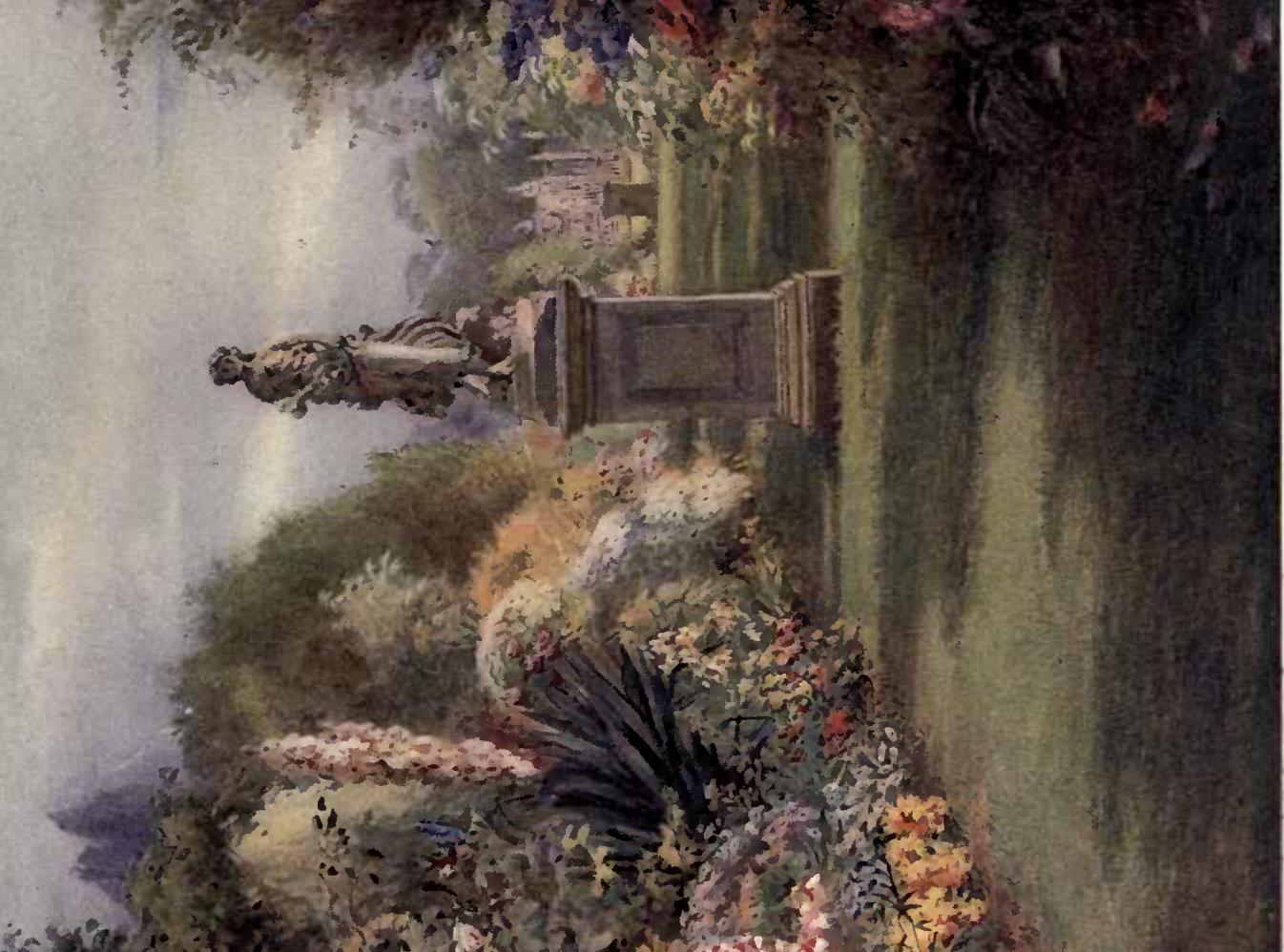

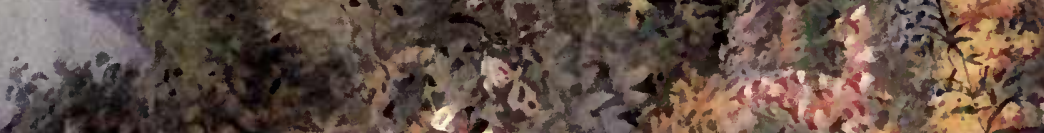

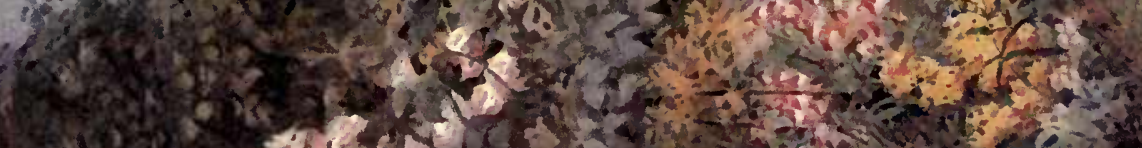

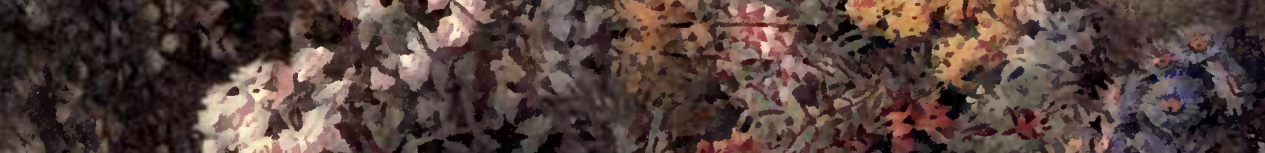

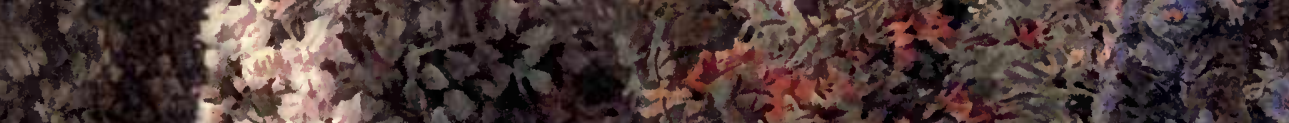

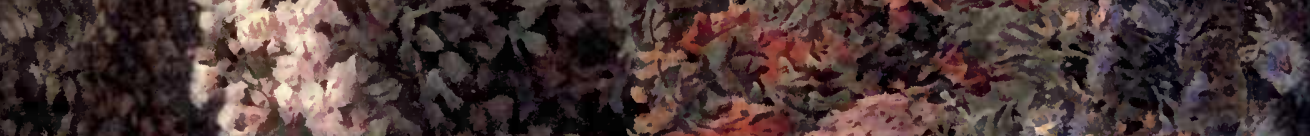

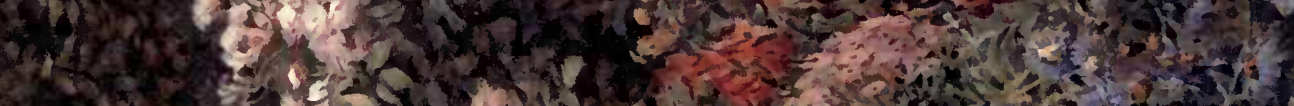

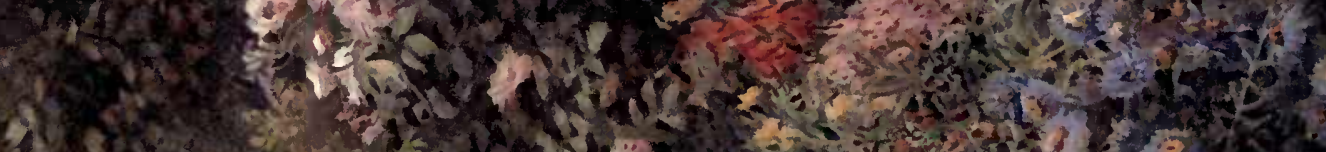

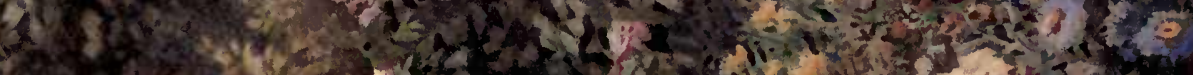

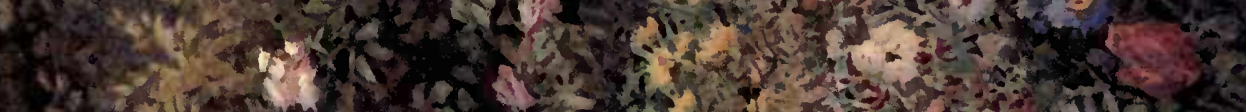





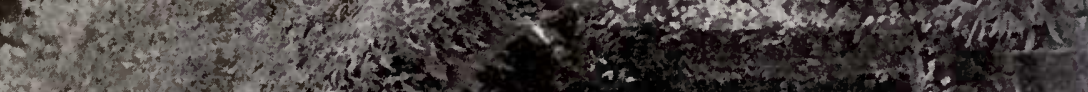

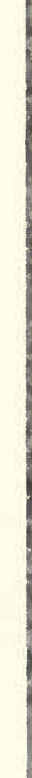

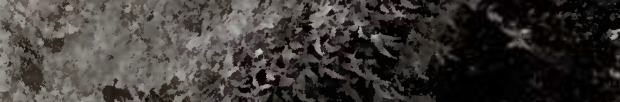

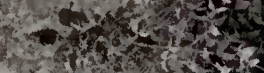

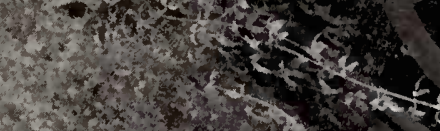

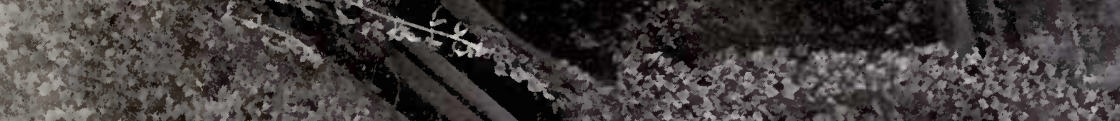

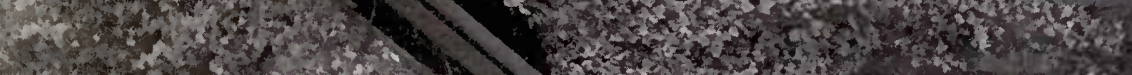

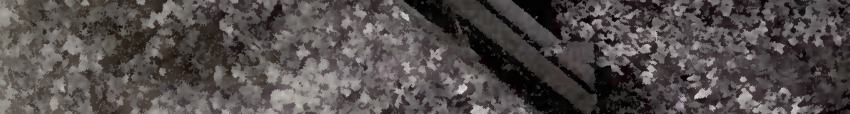

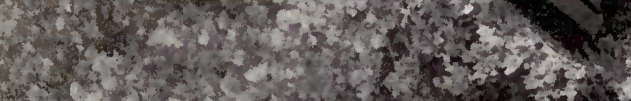
$x^{2}+x^{2}$

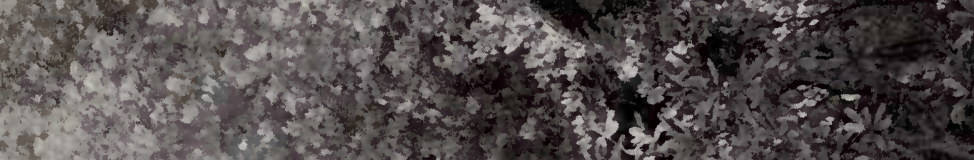

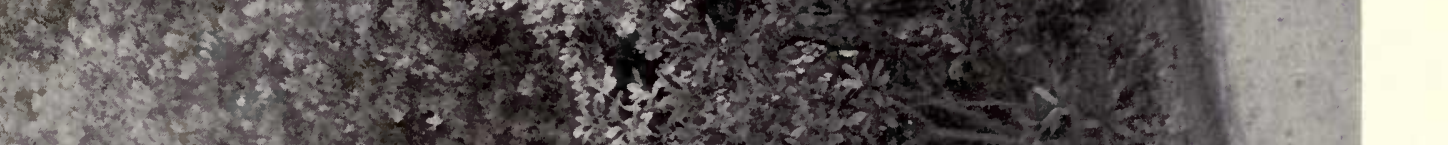




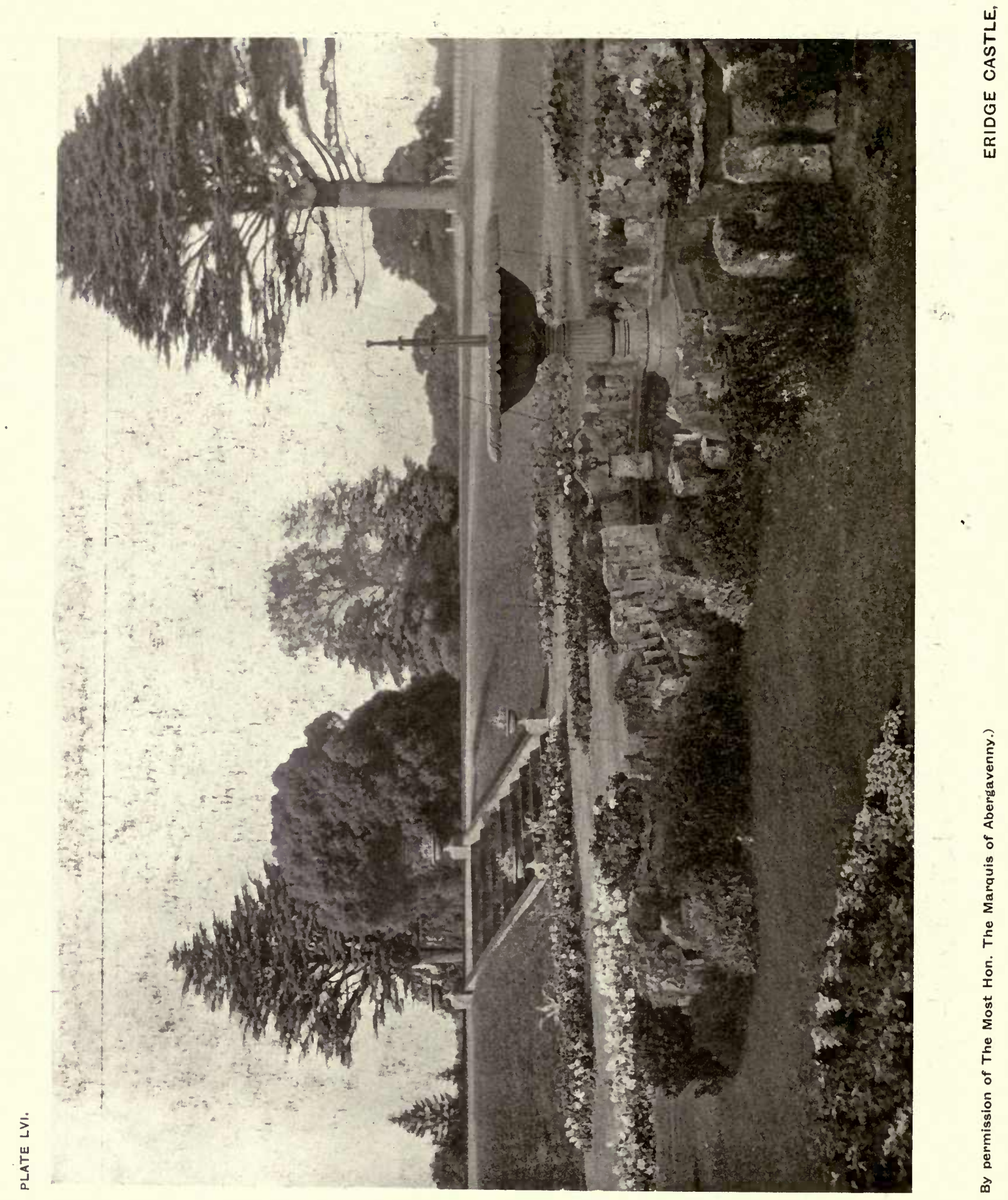




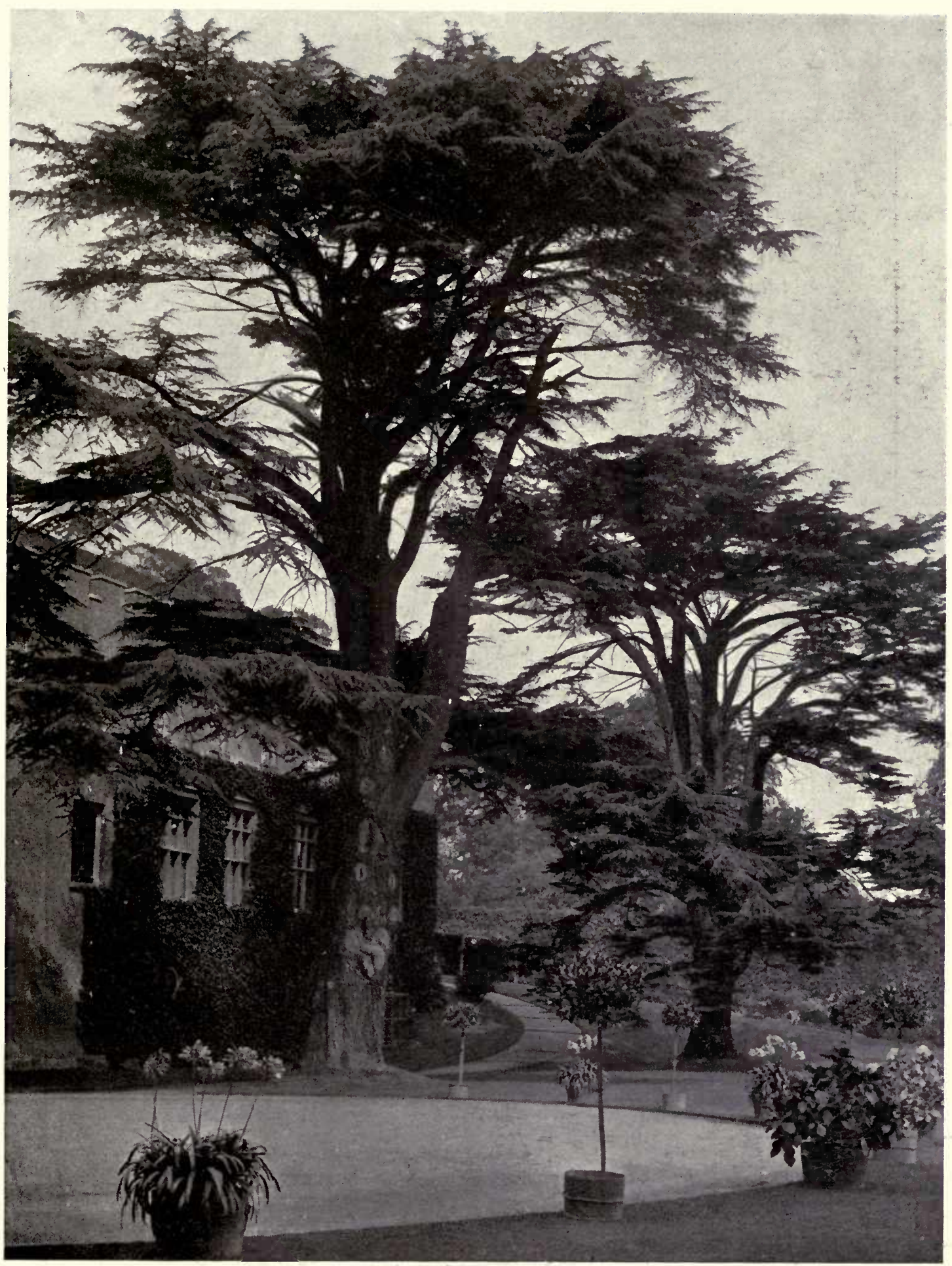




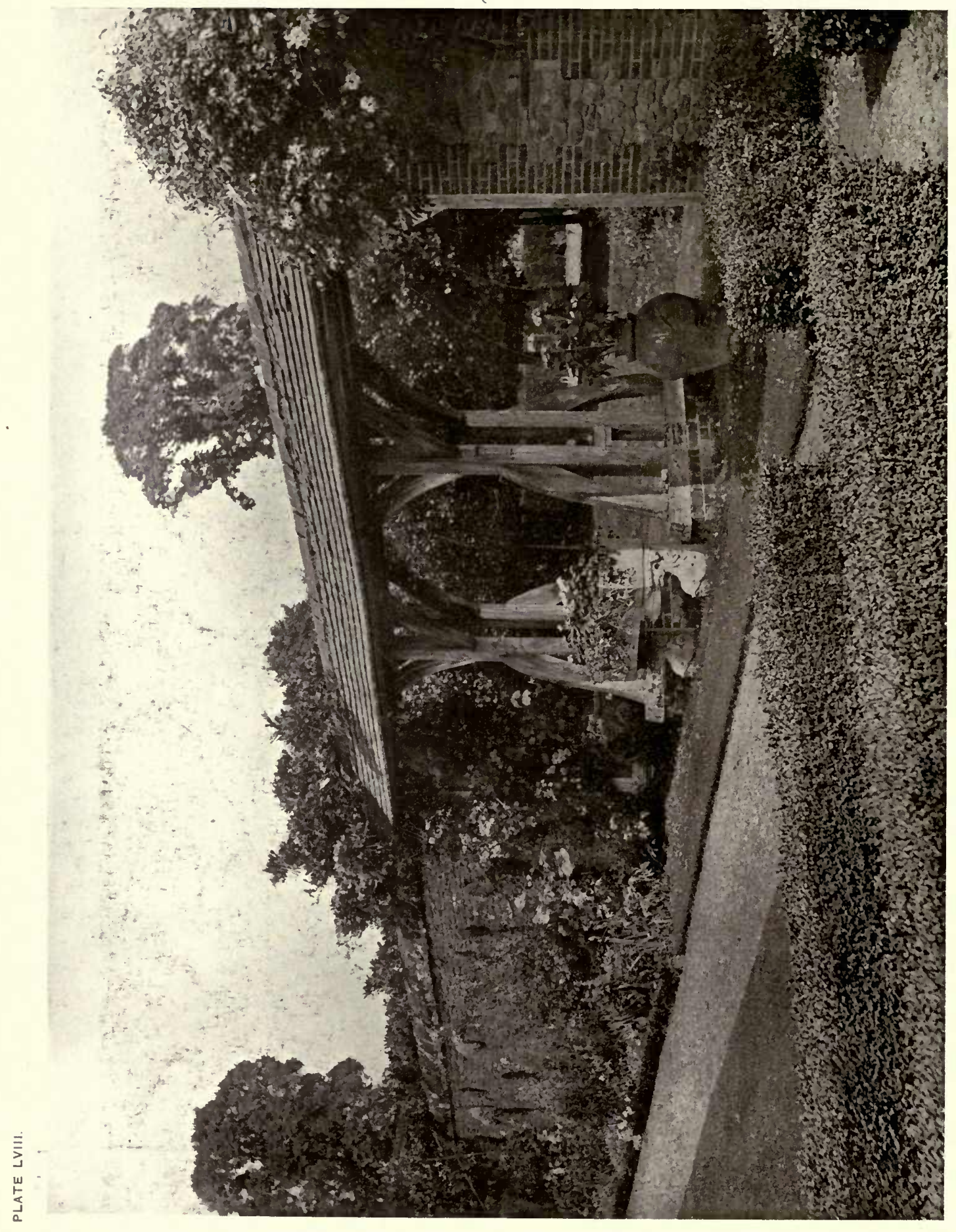

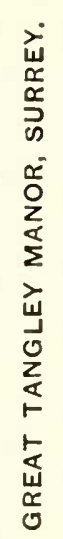




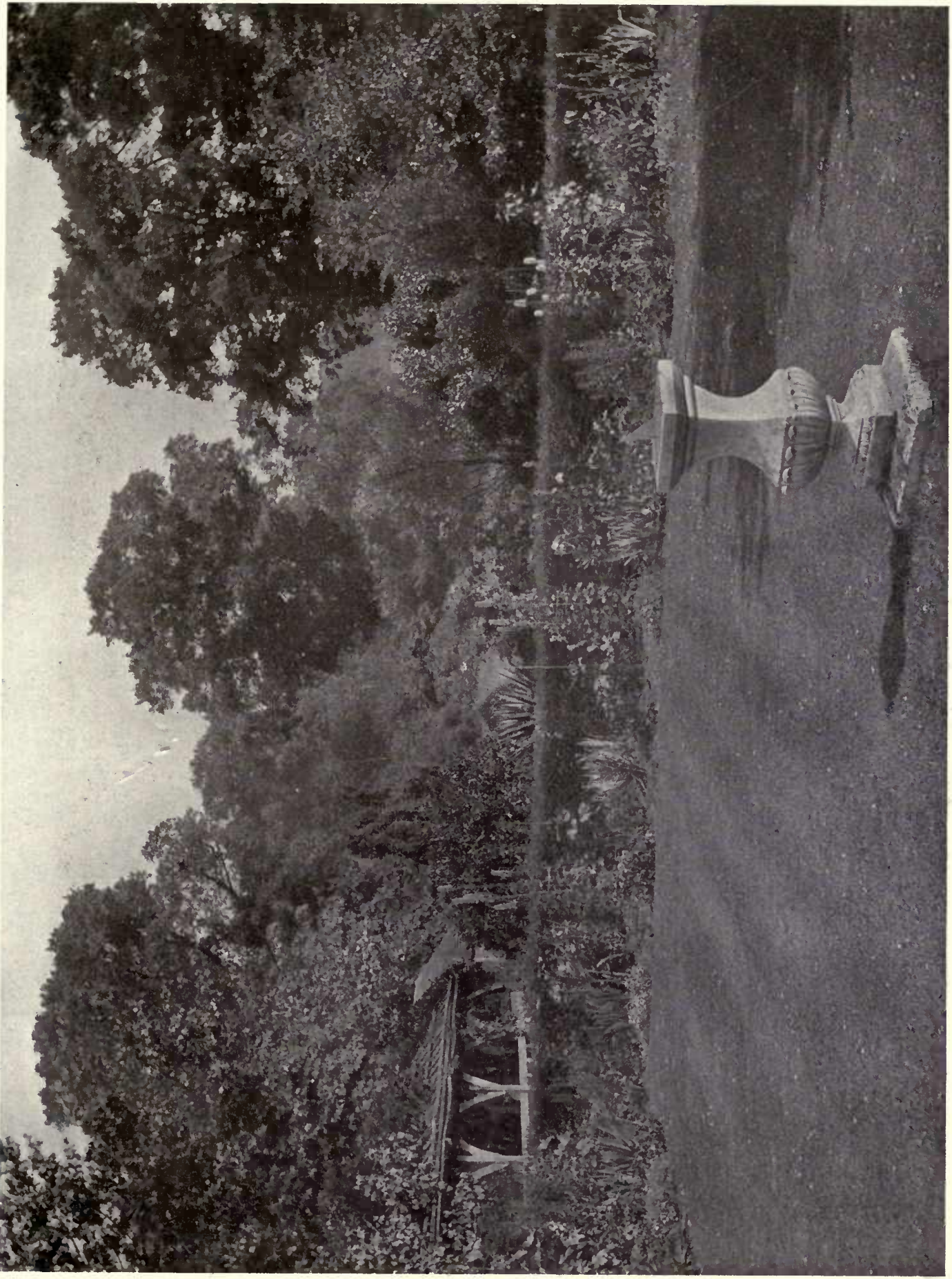




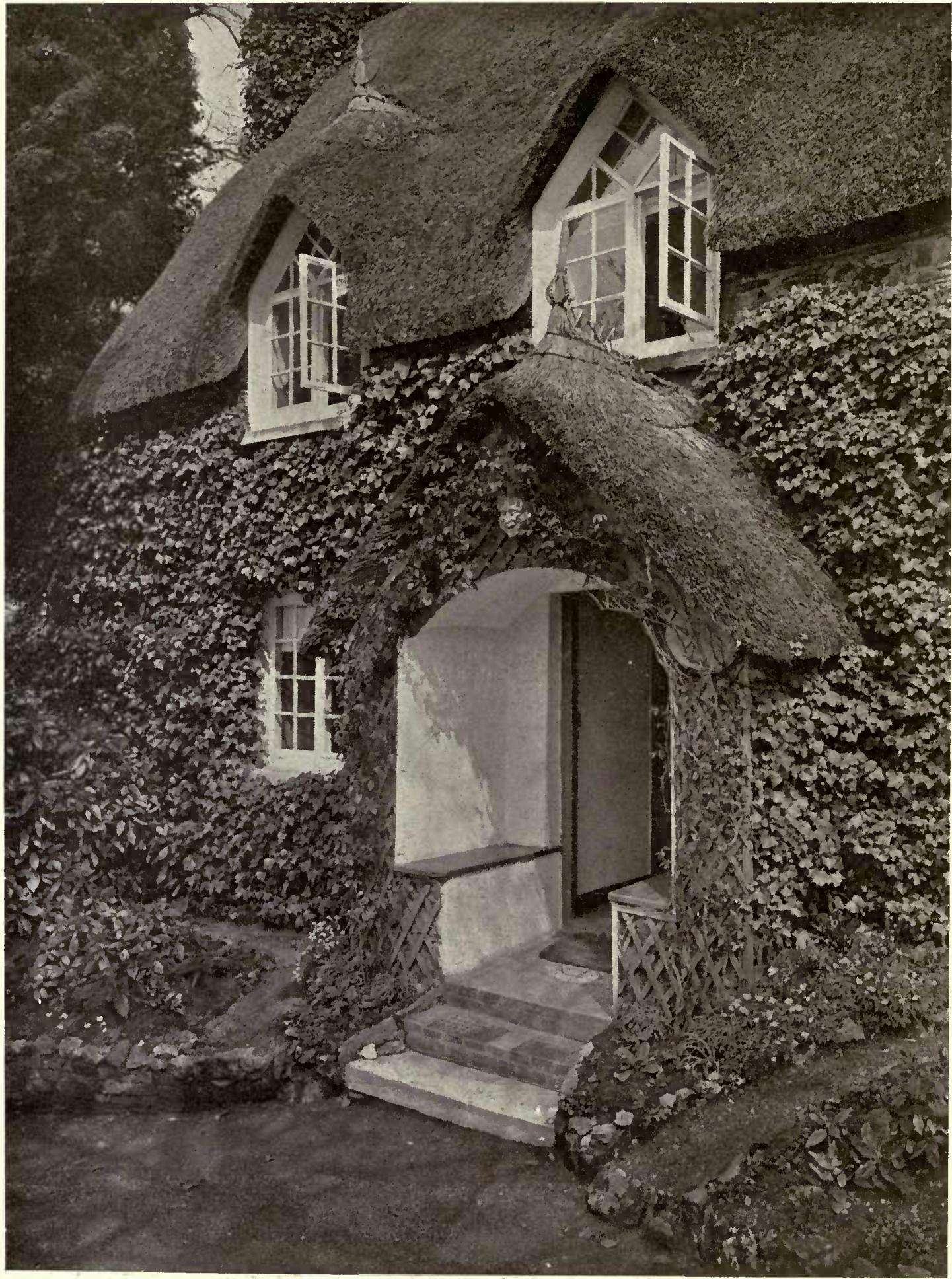




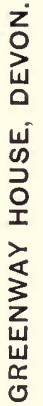

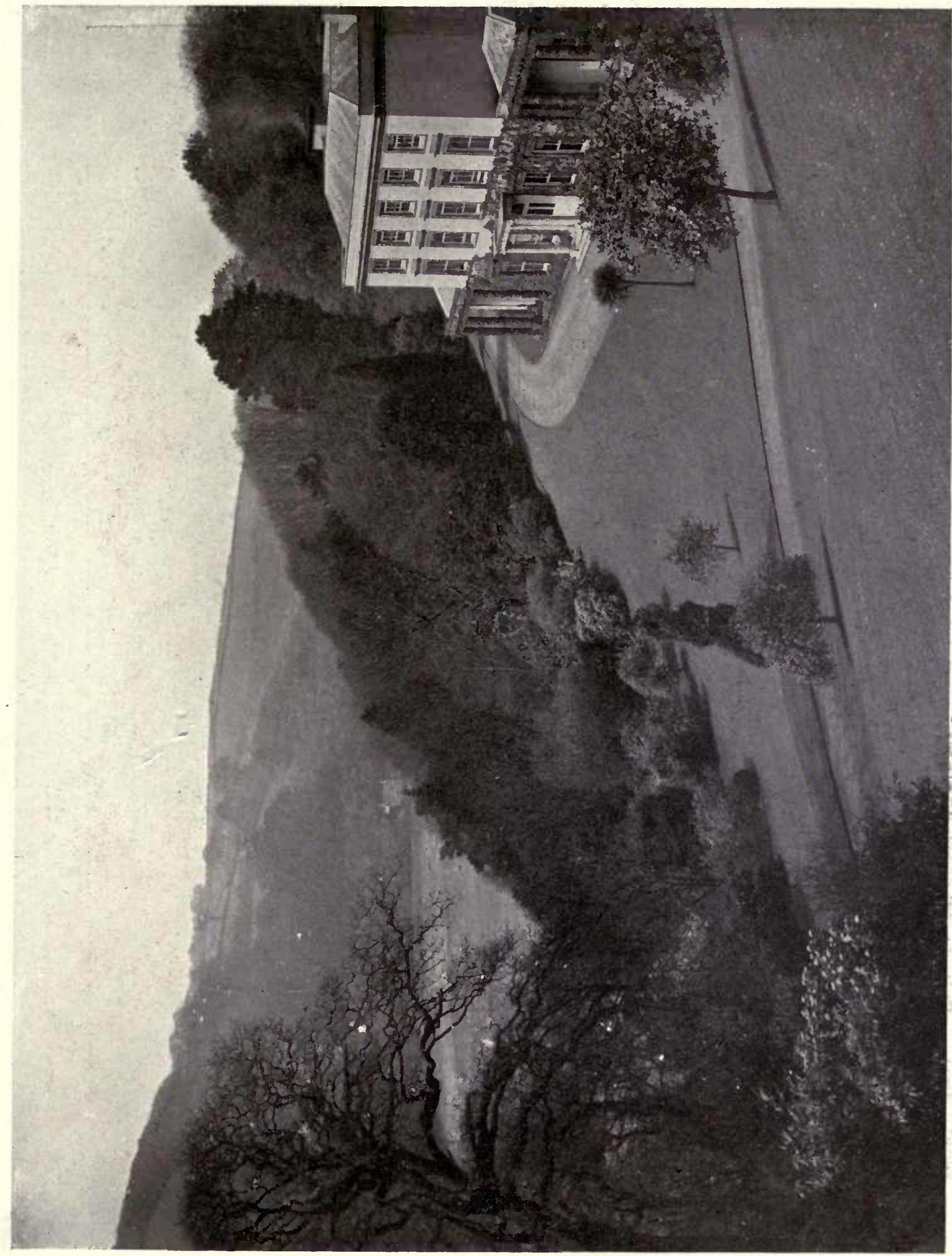

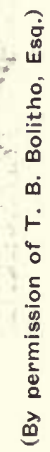




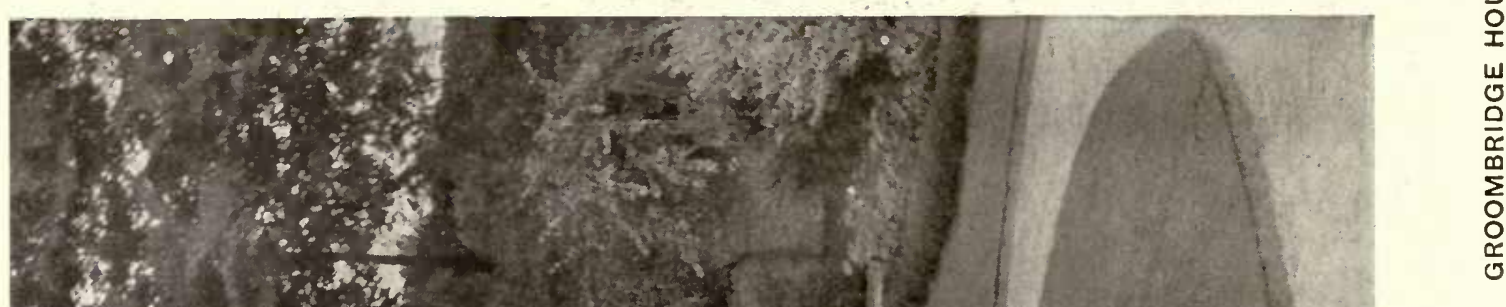

2.

t. 3.8

- 940 is

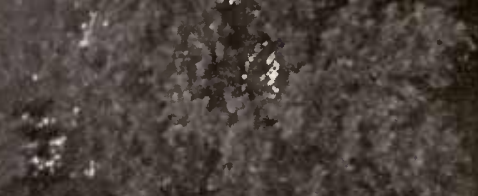

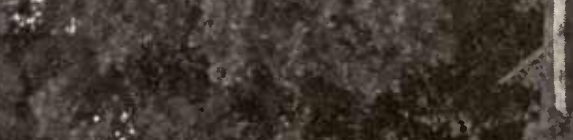

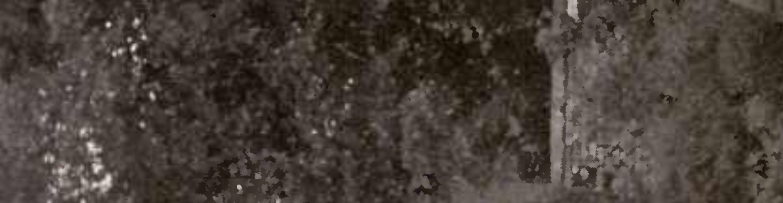

(3) 12 , is

a.s.

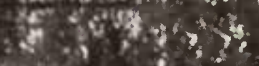

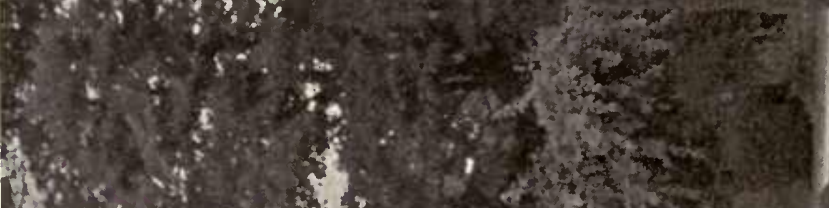

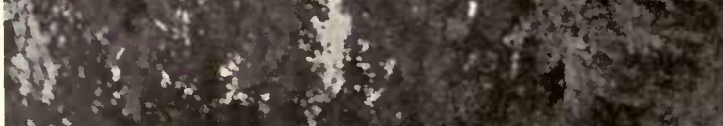

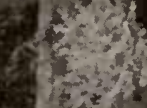

-
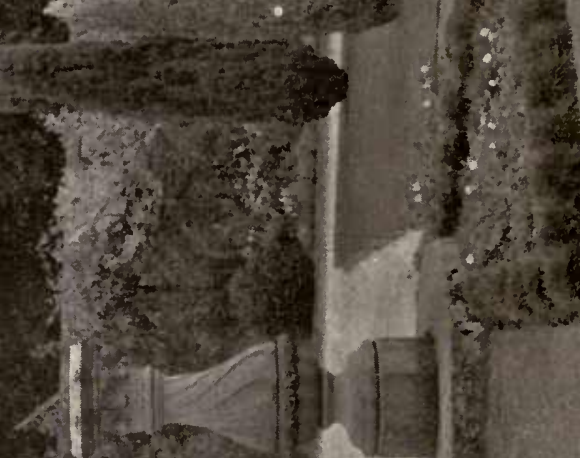
$\sin x$

产

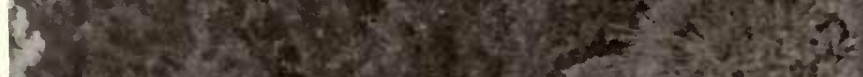

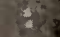




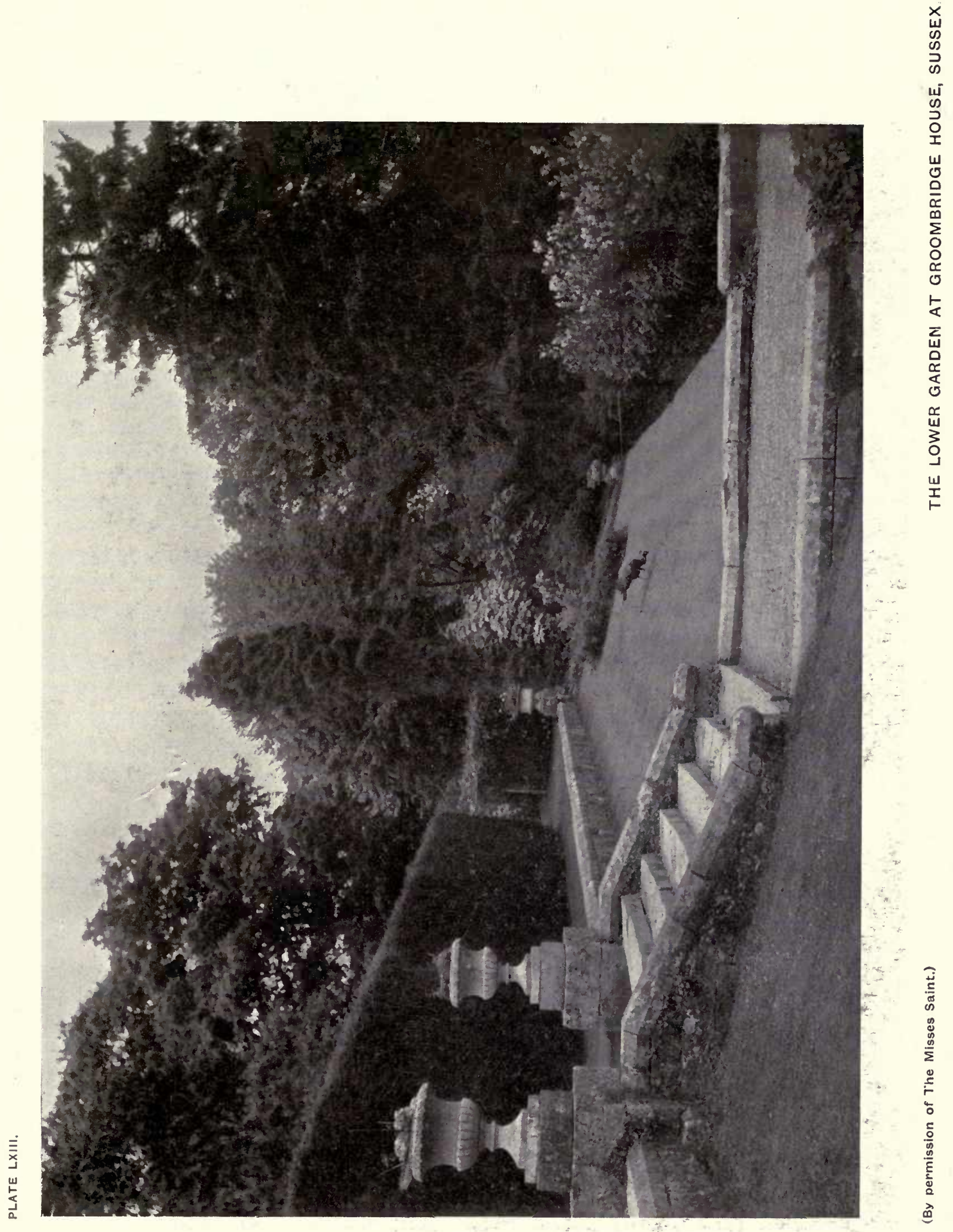




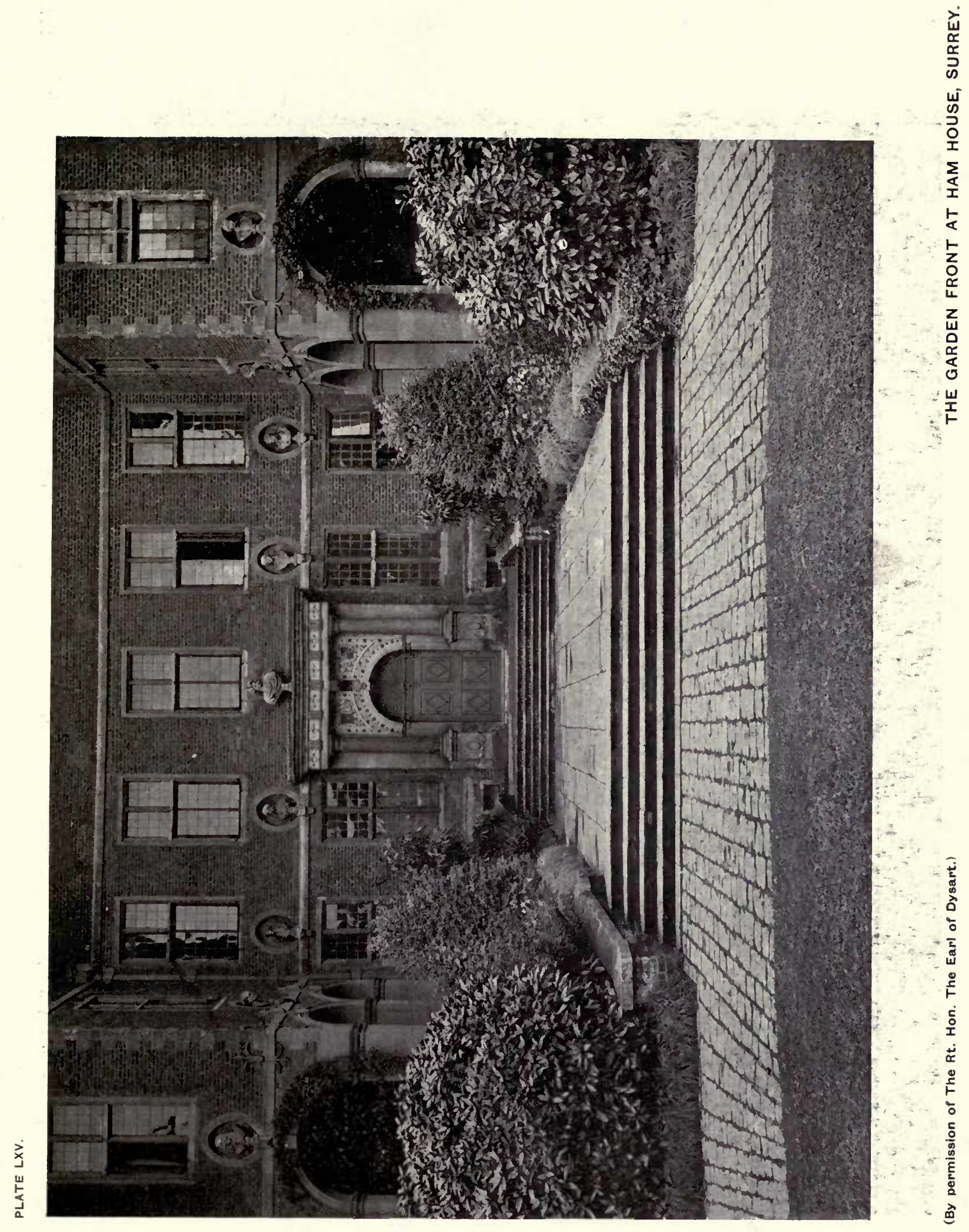




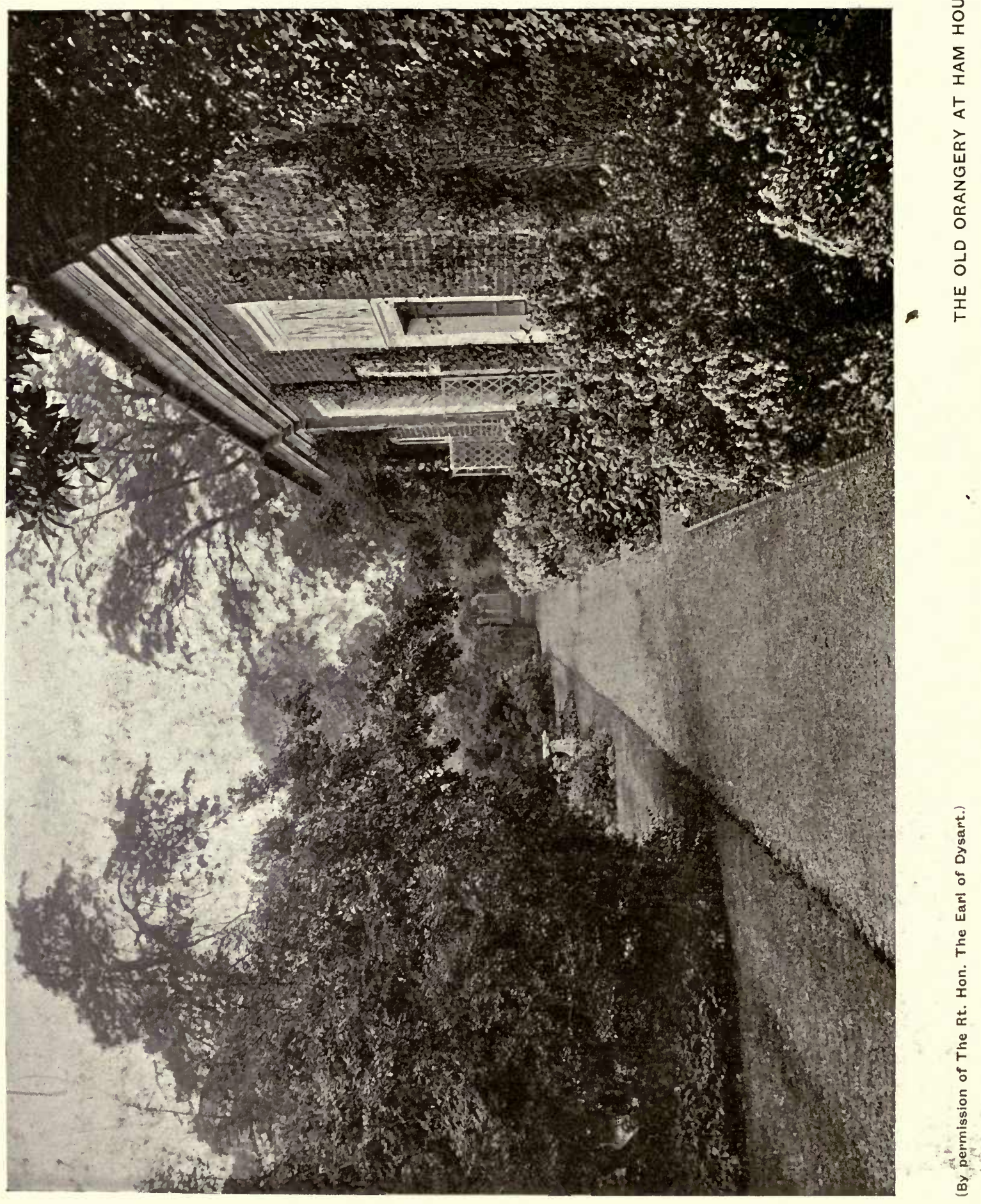




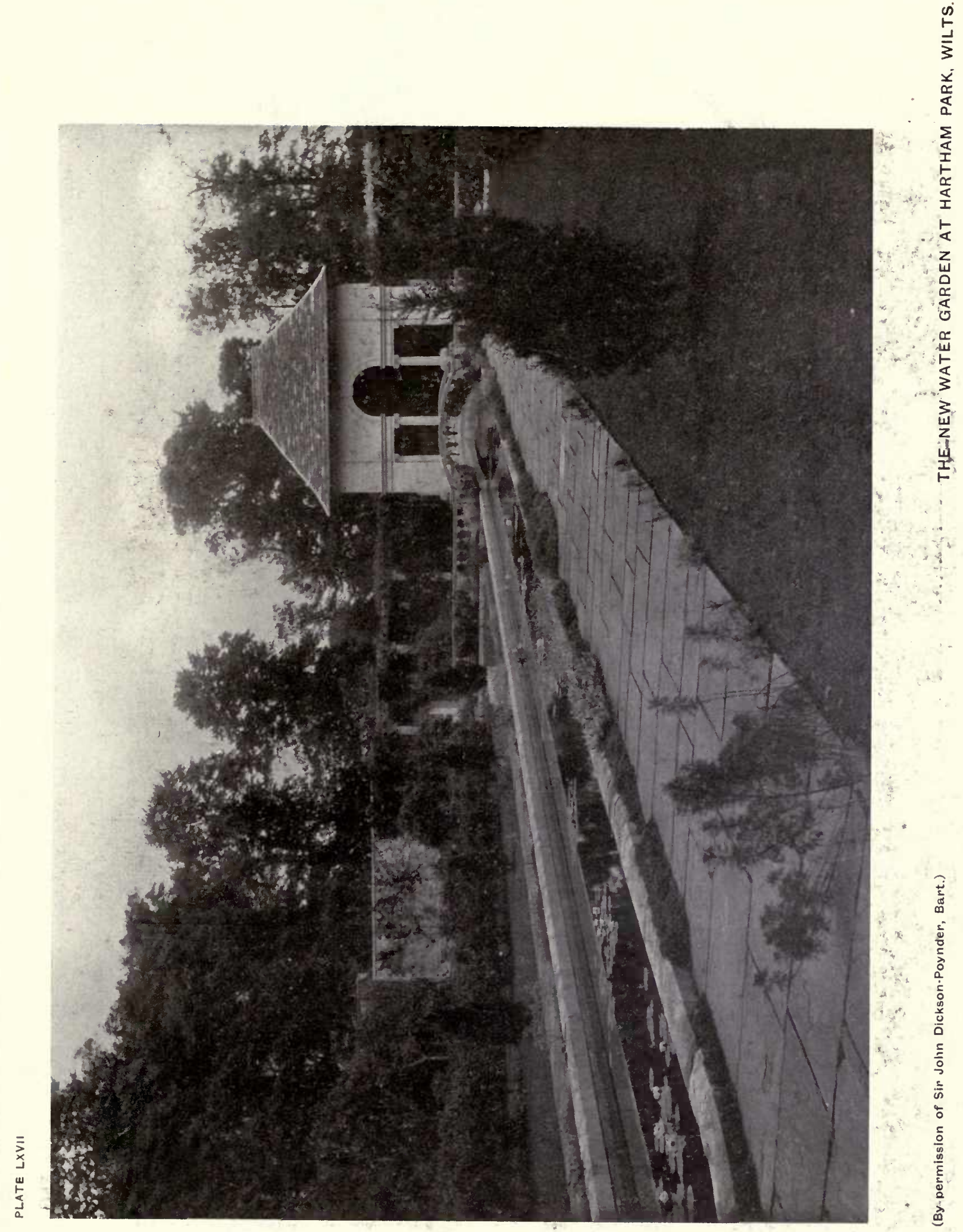



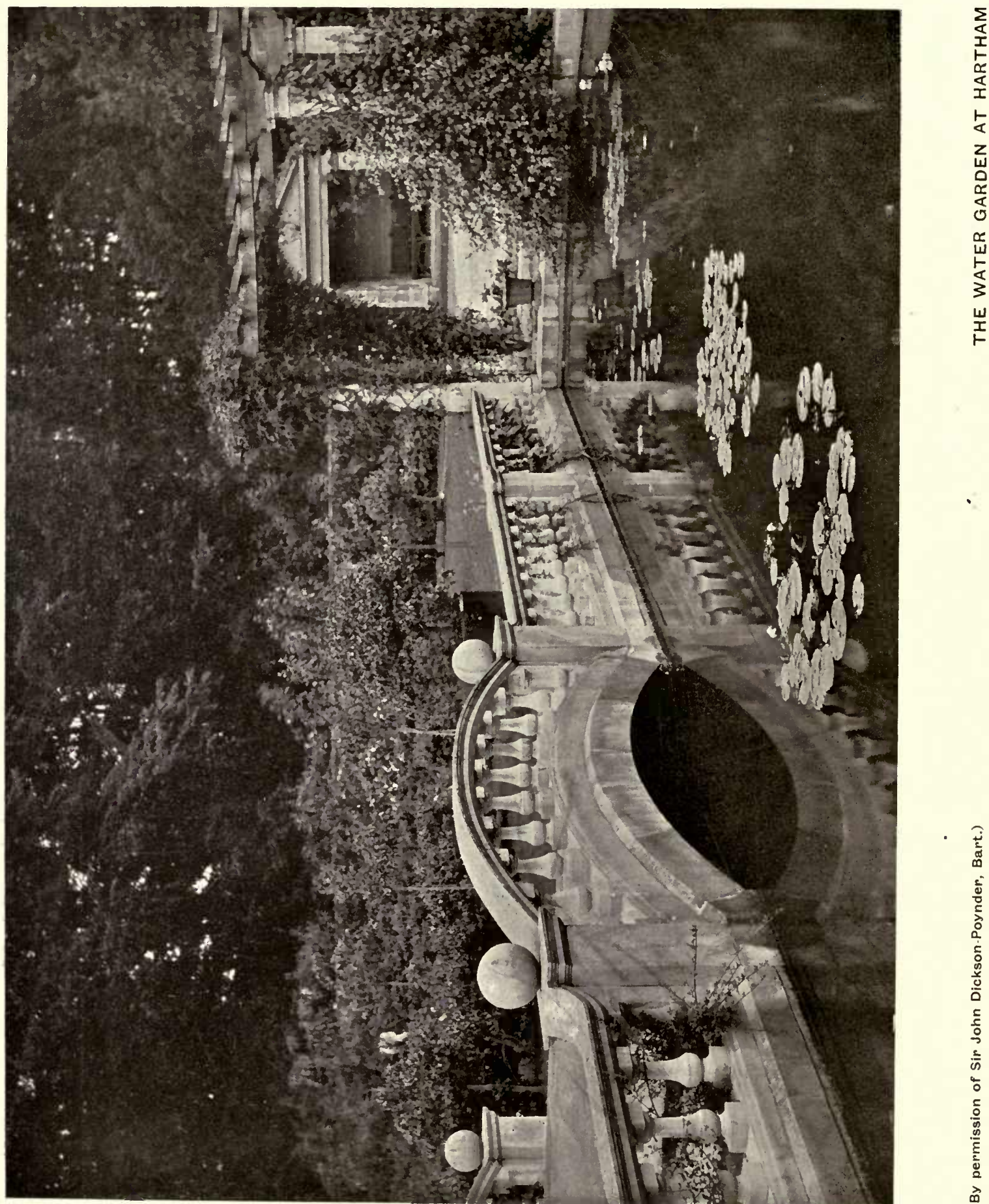

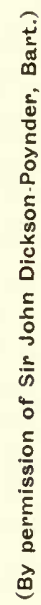




\section{PLATE LXIX.}

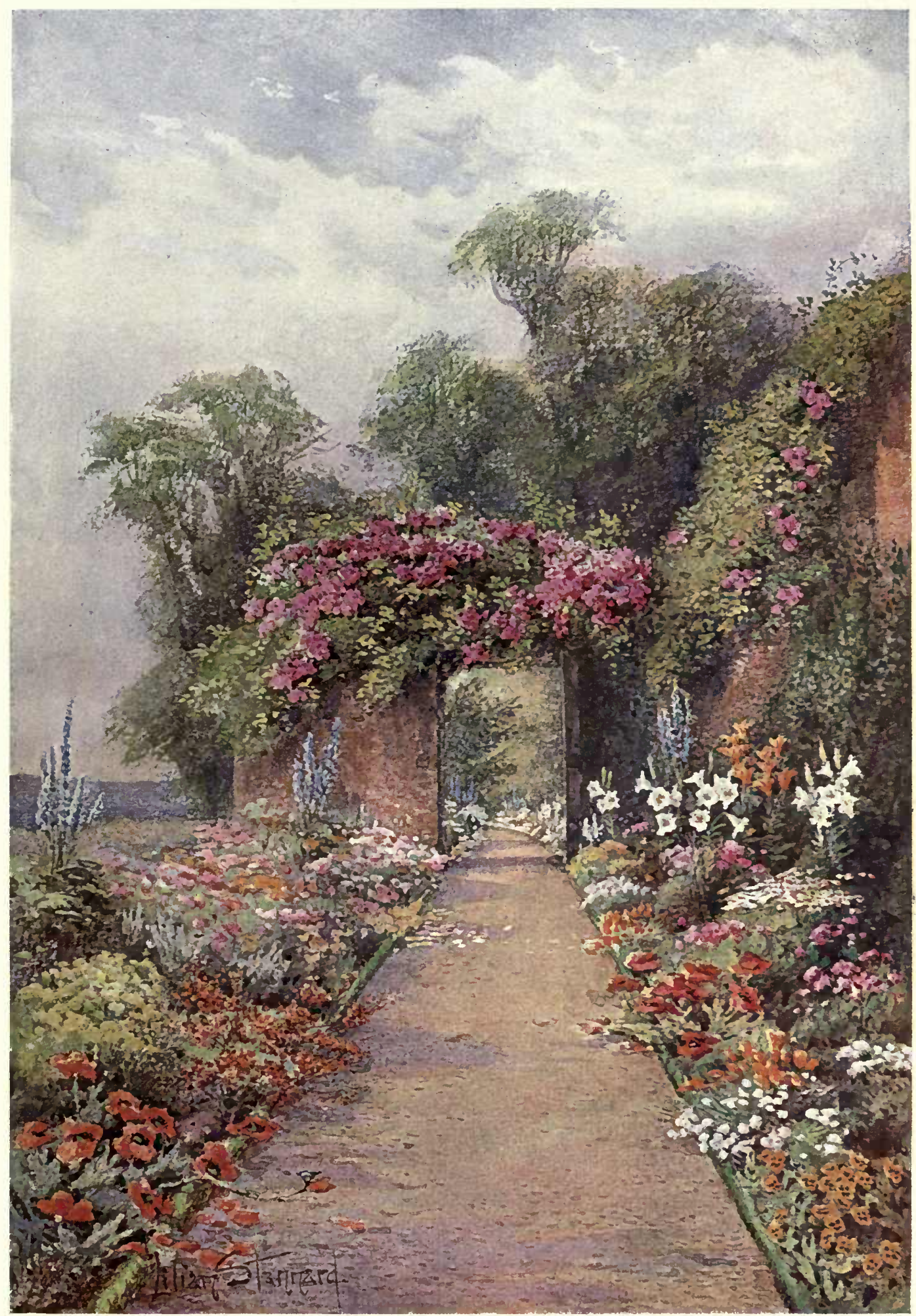




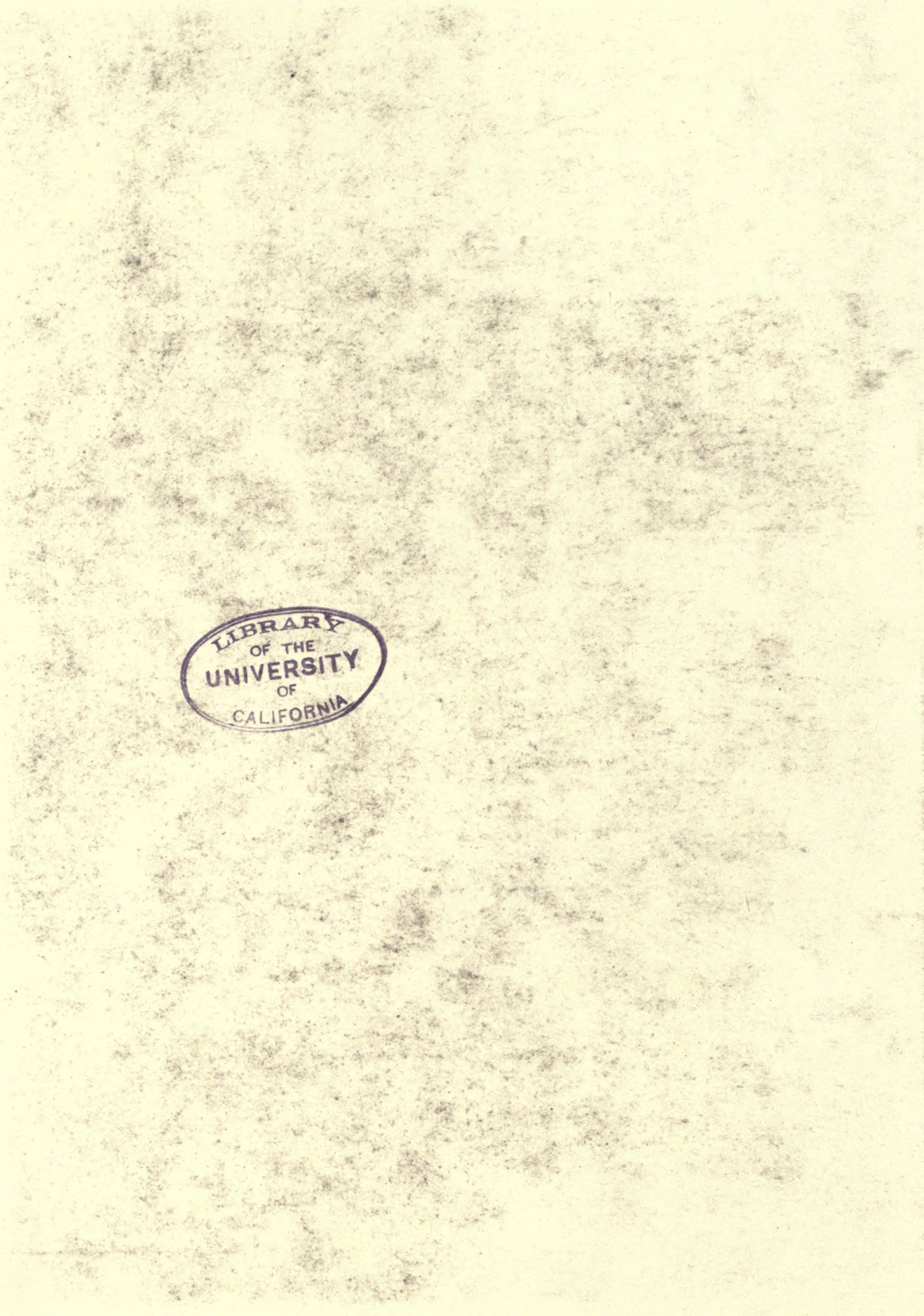




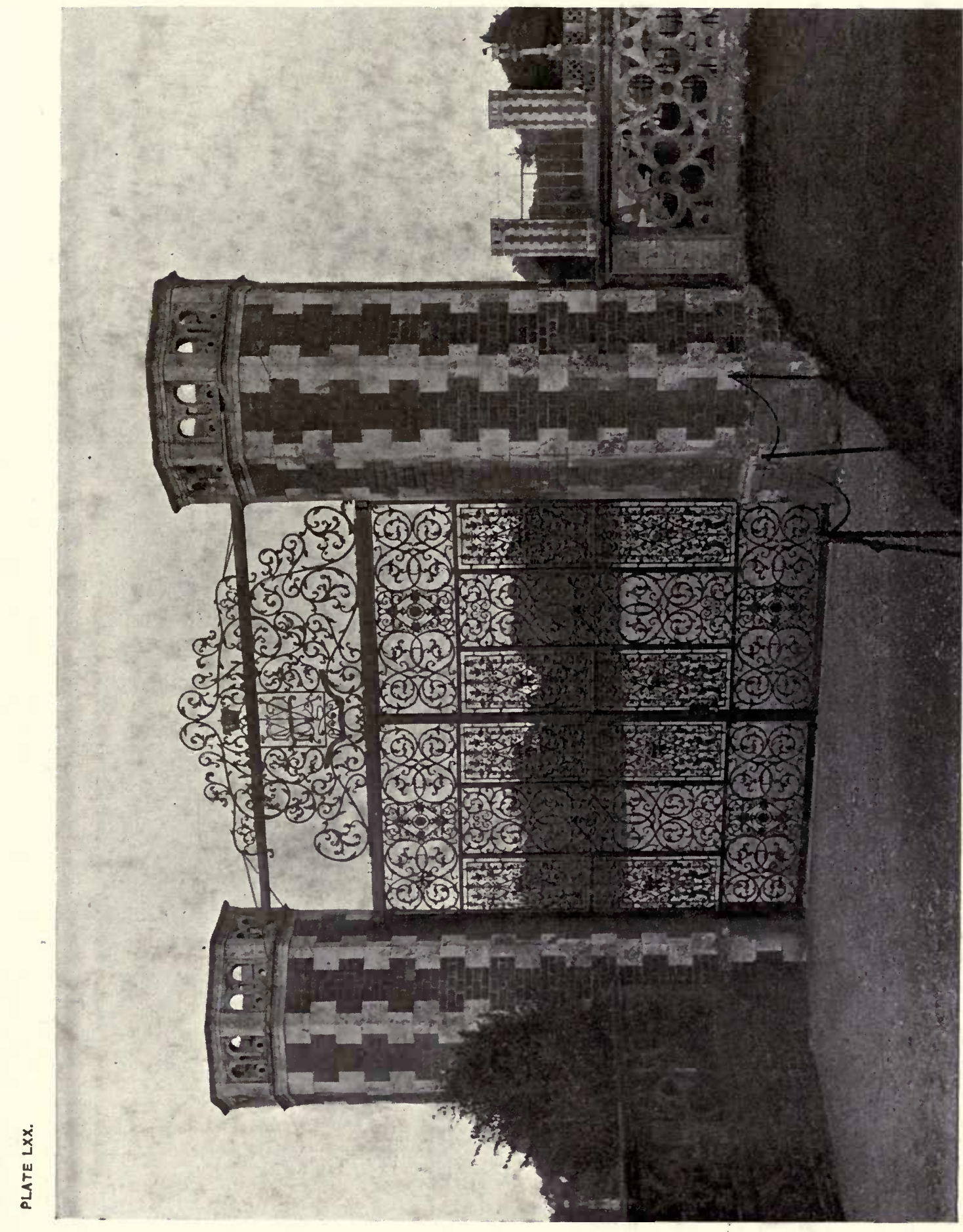

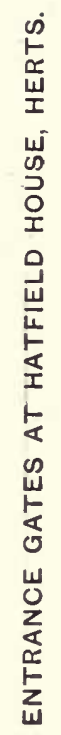




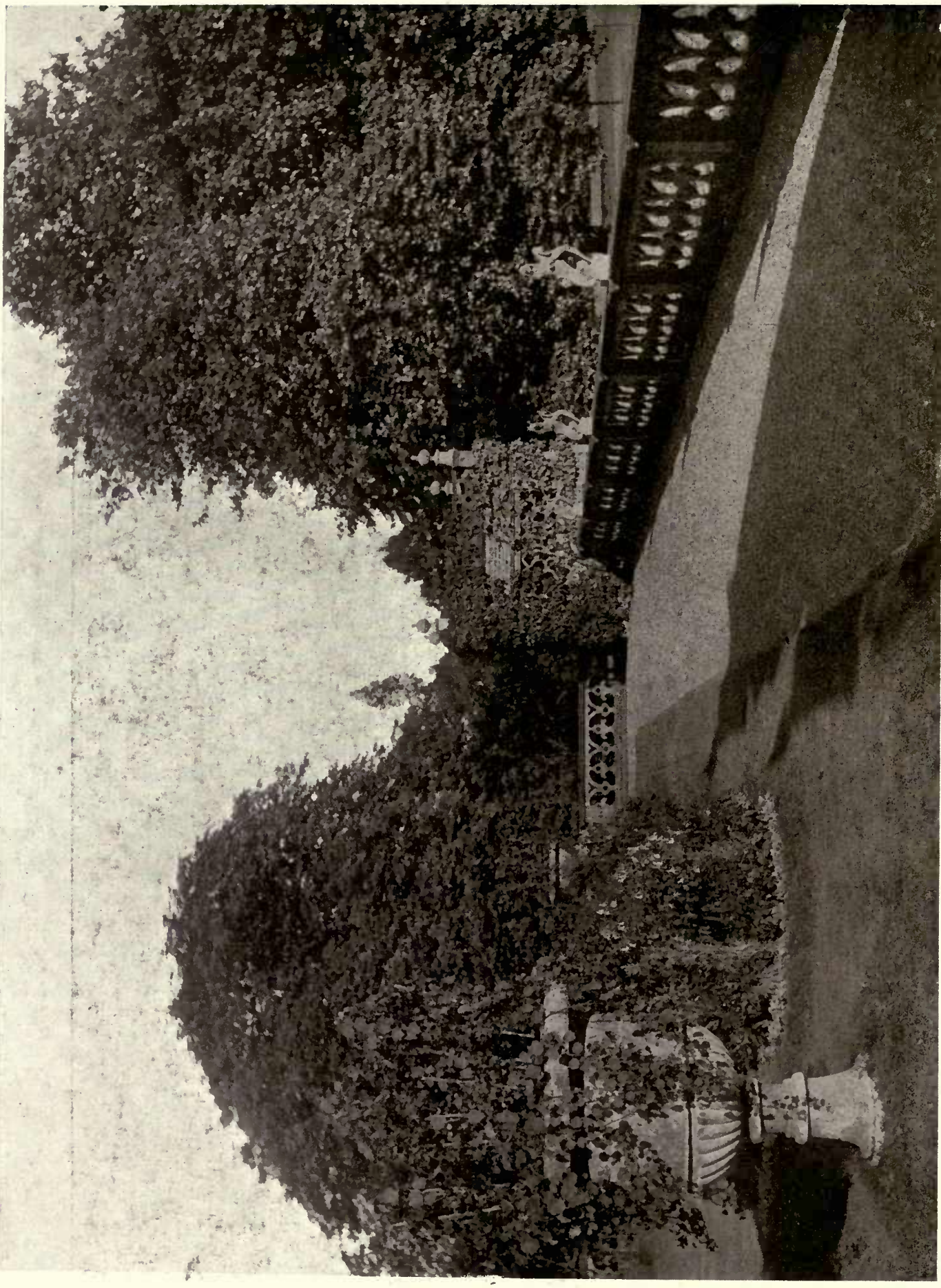




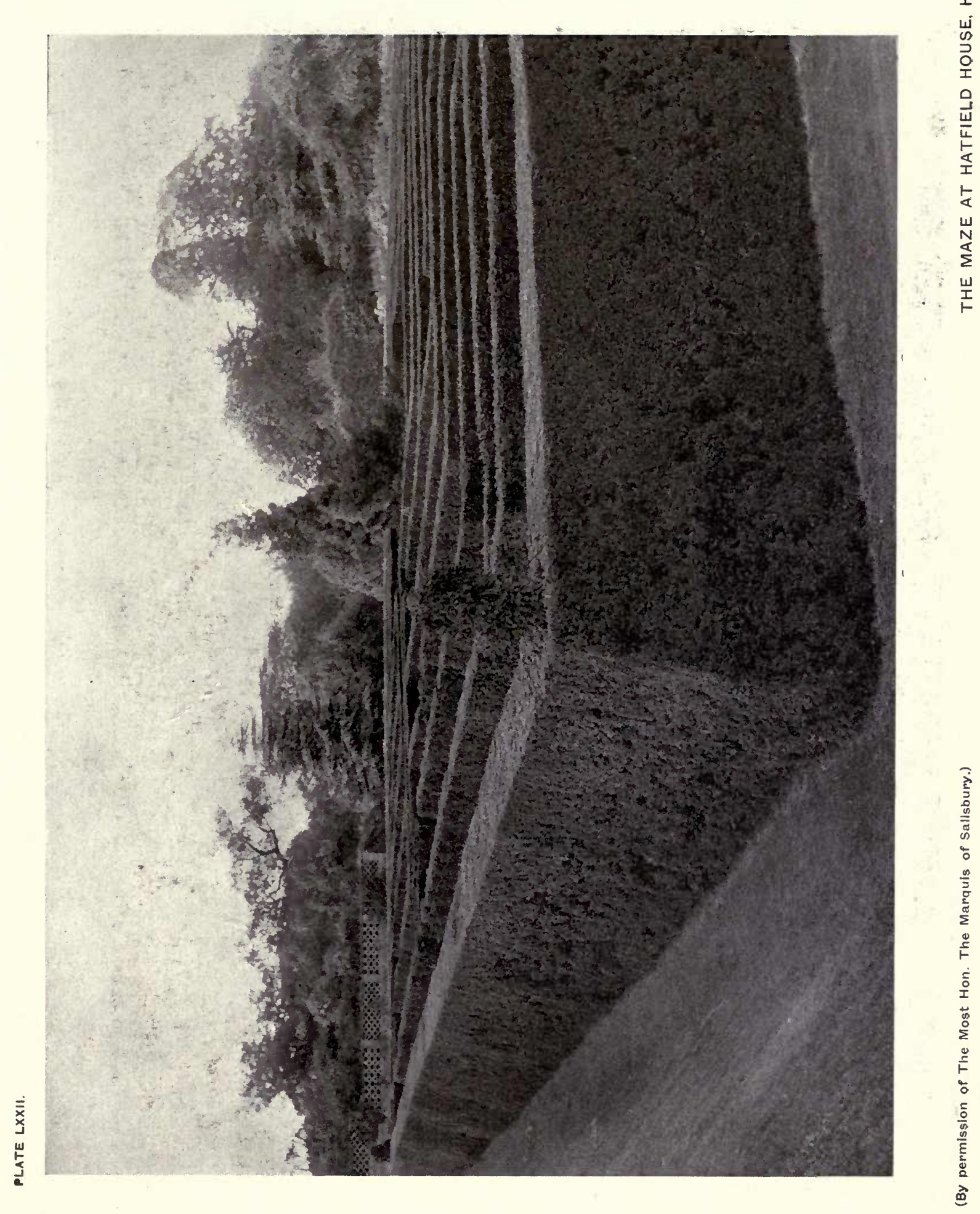




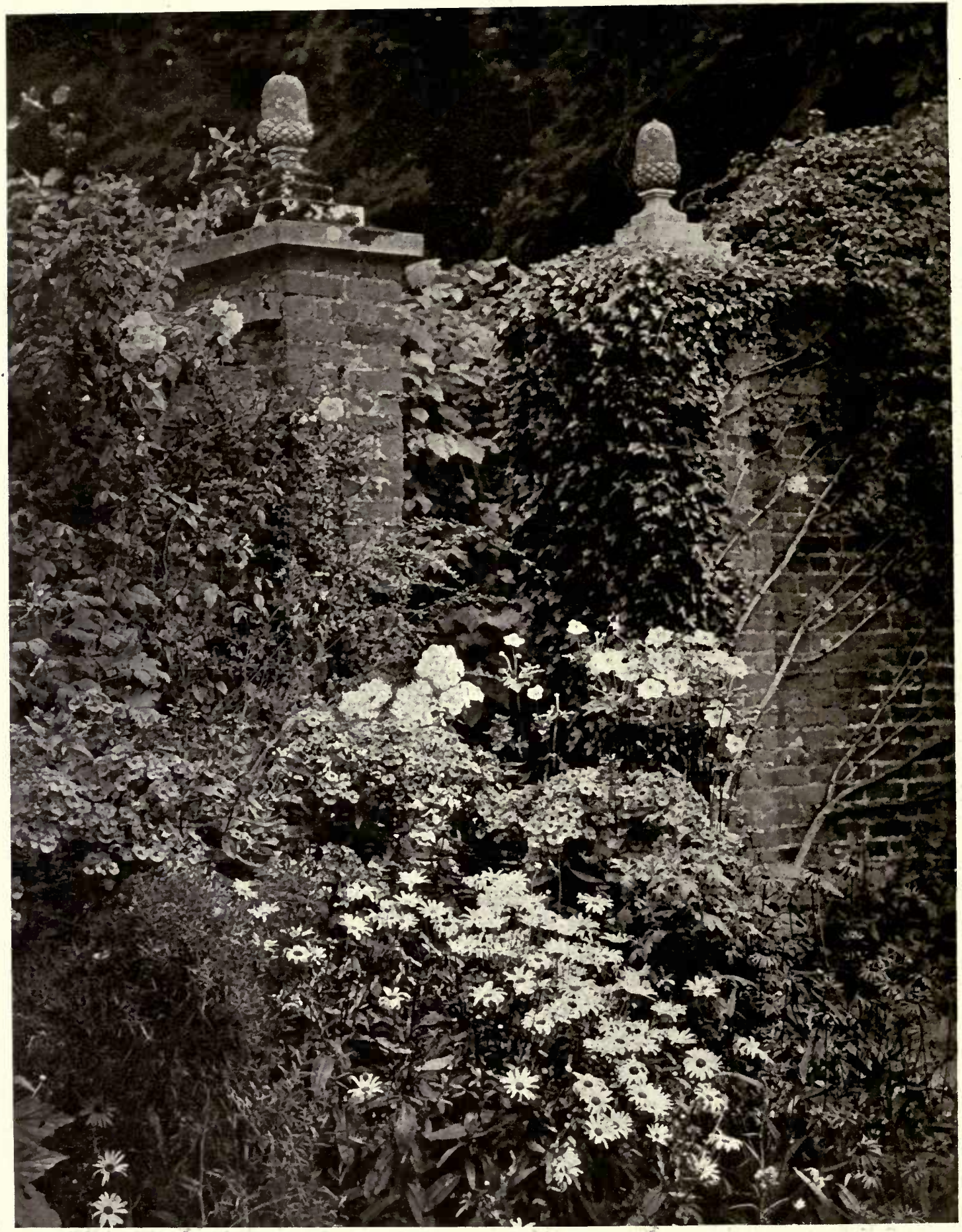




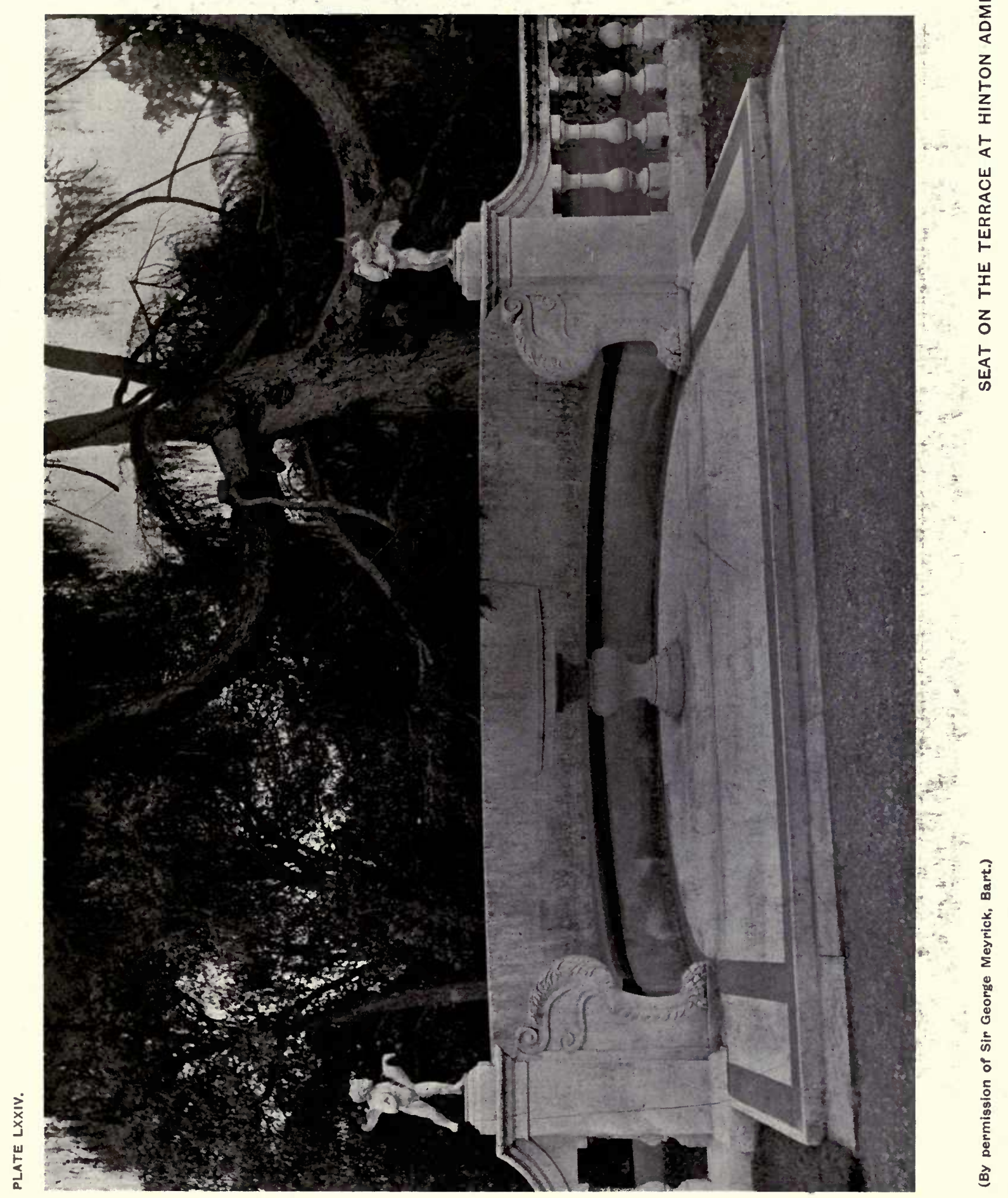




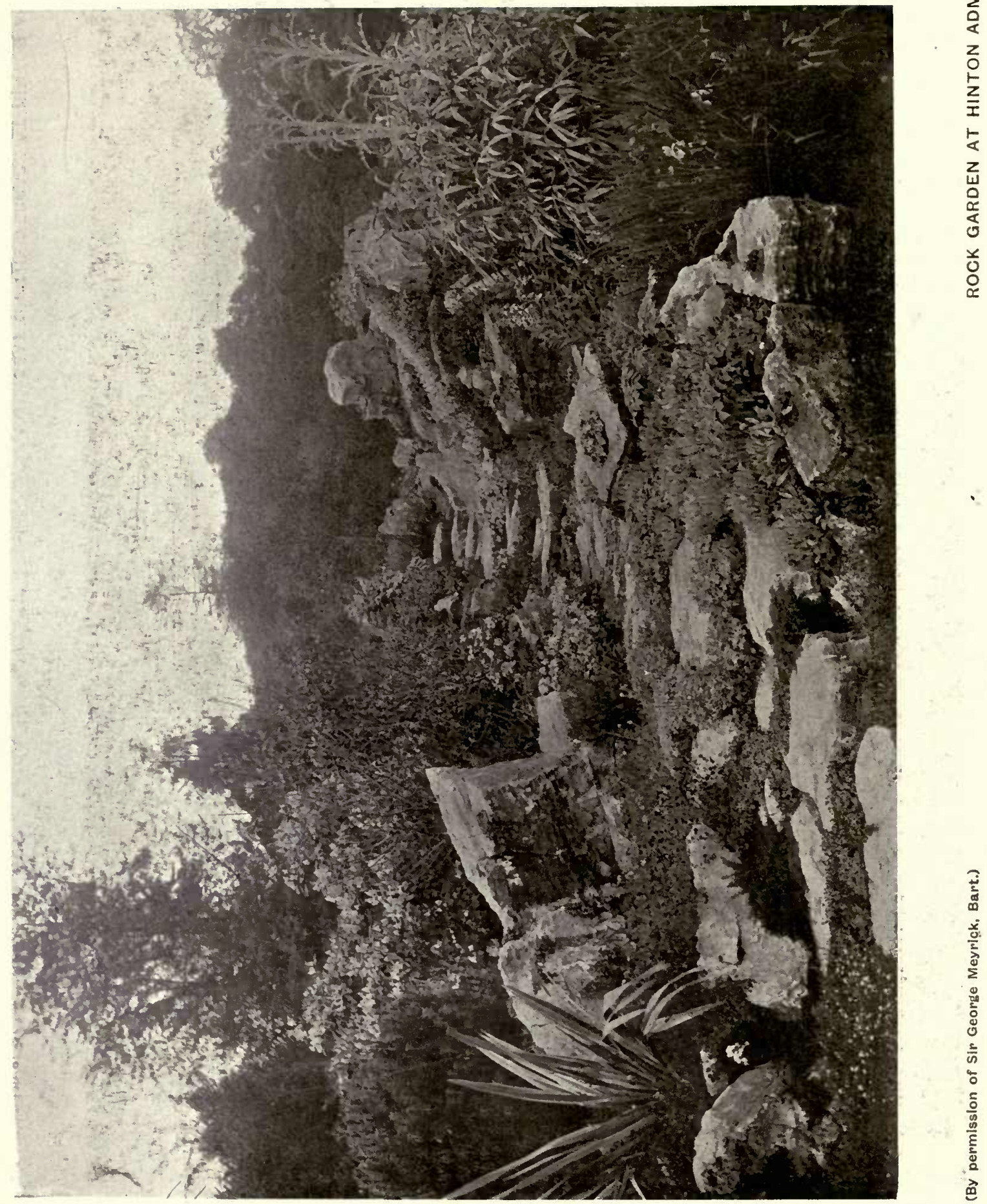




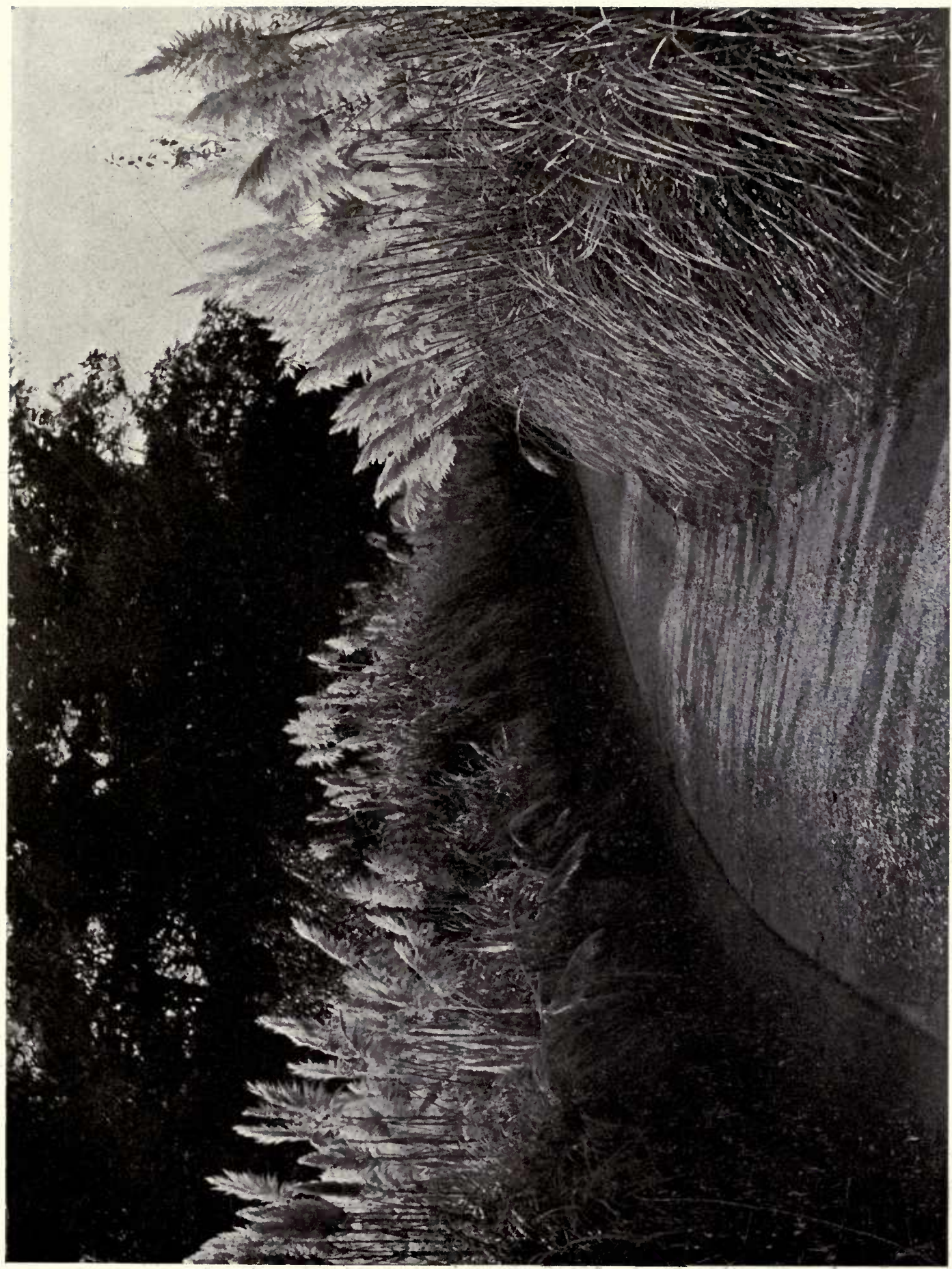




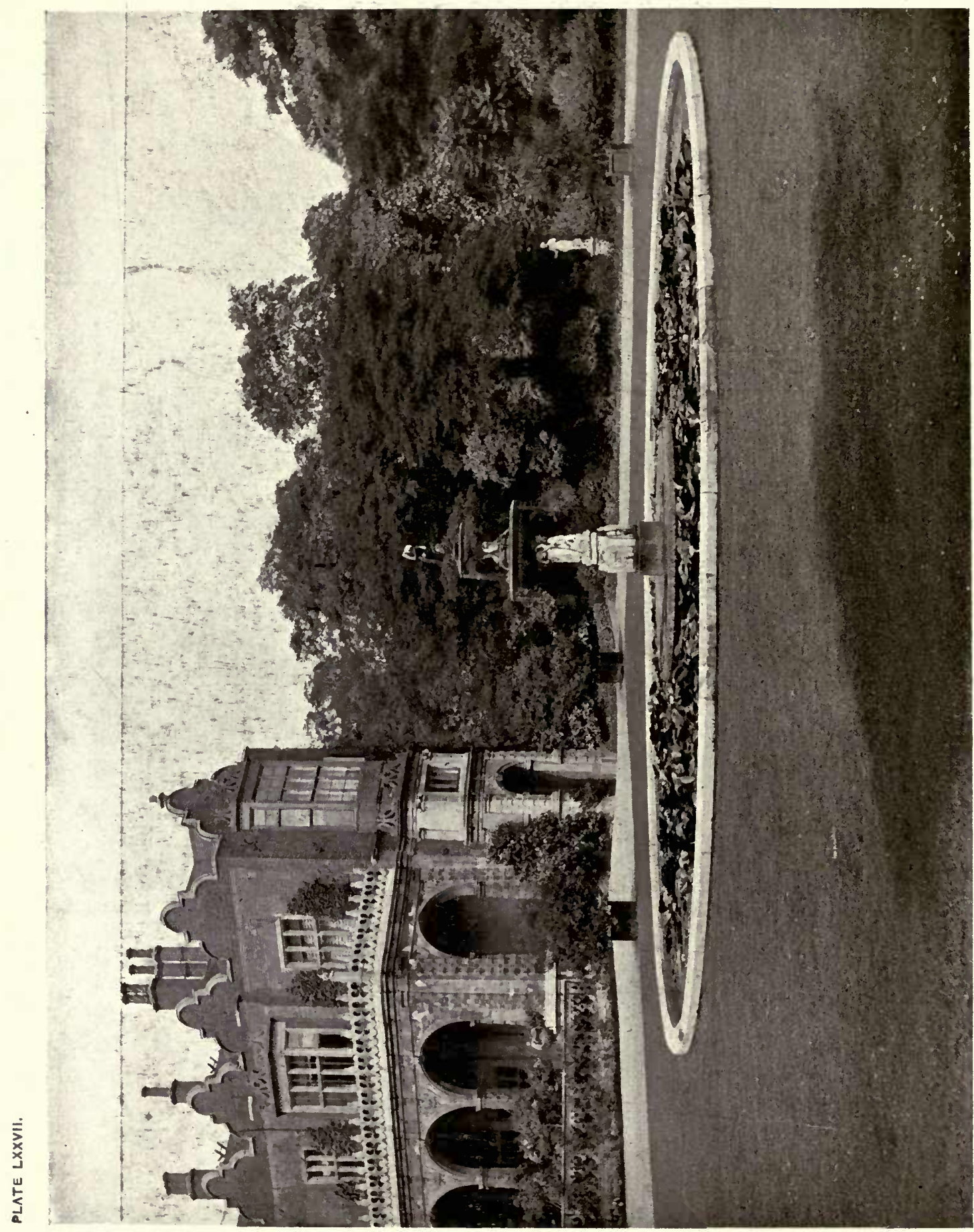

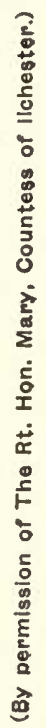




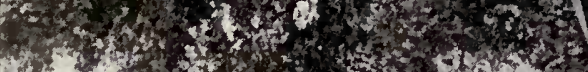

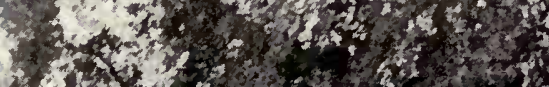

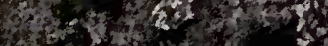

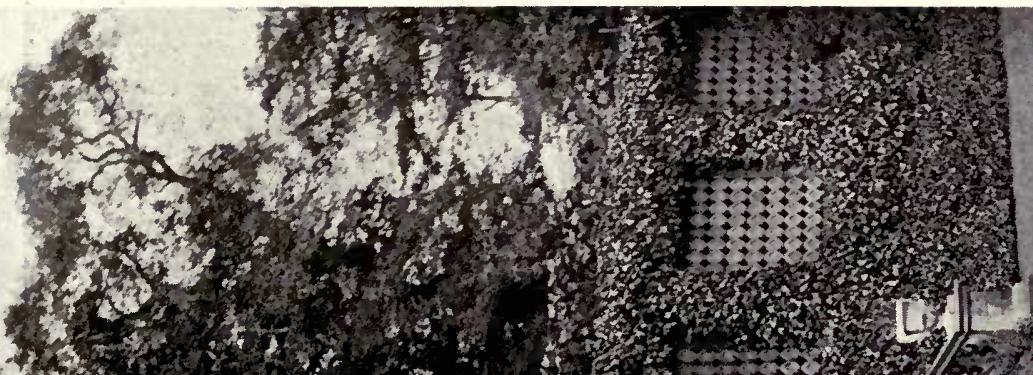

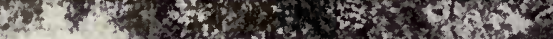
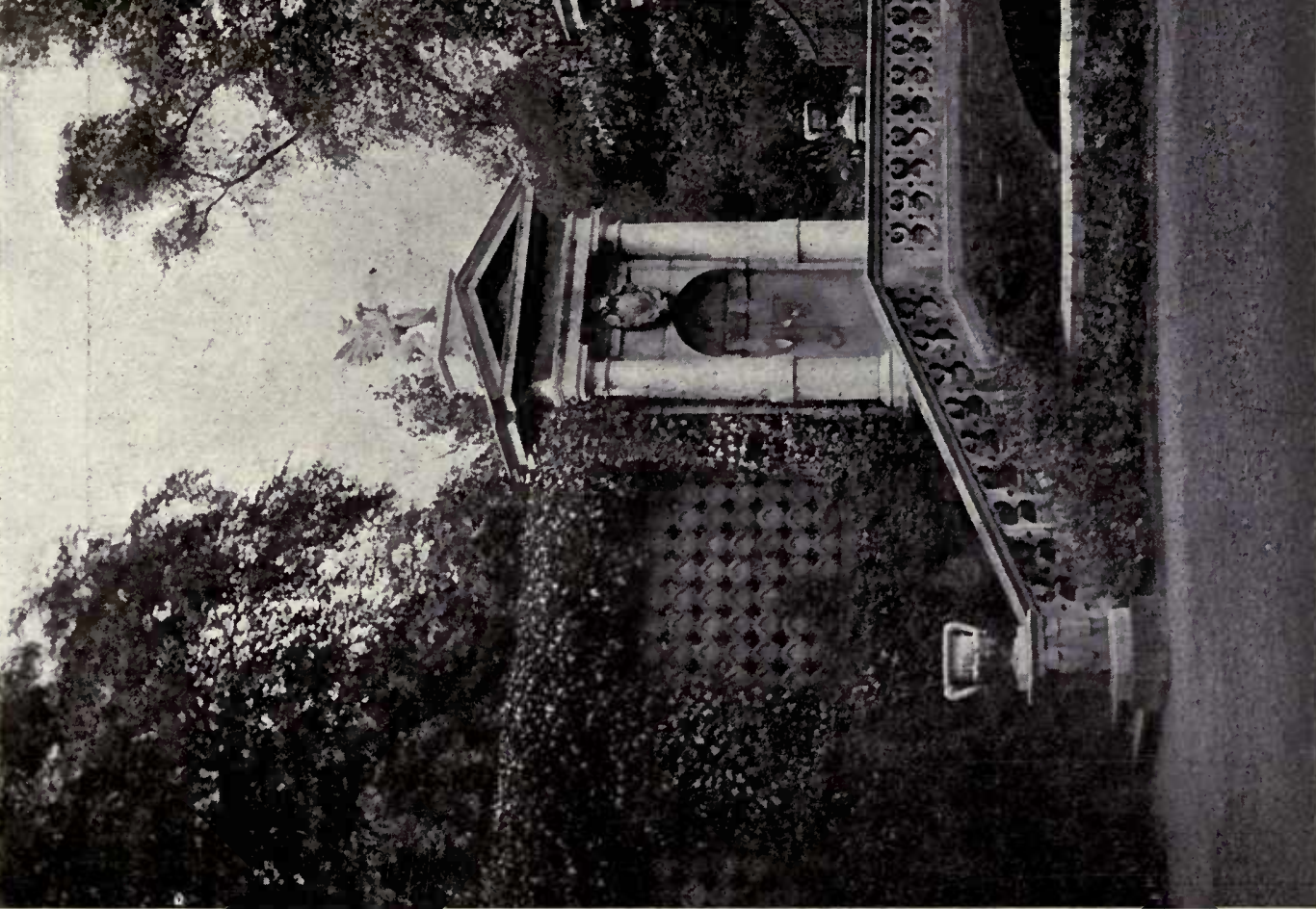

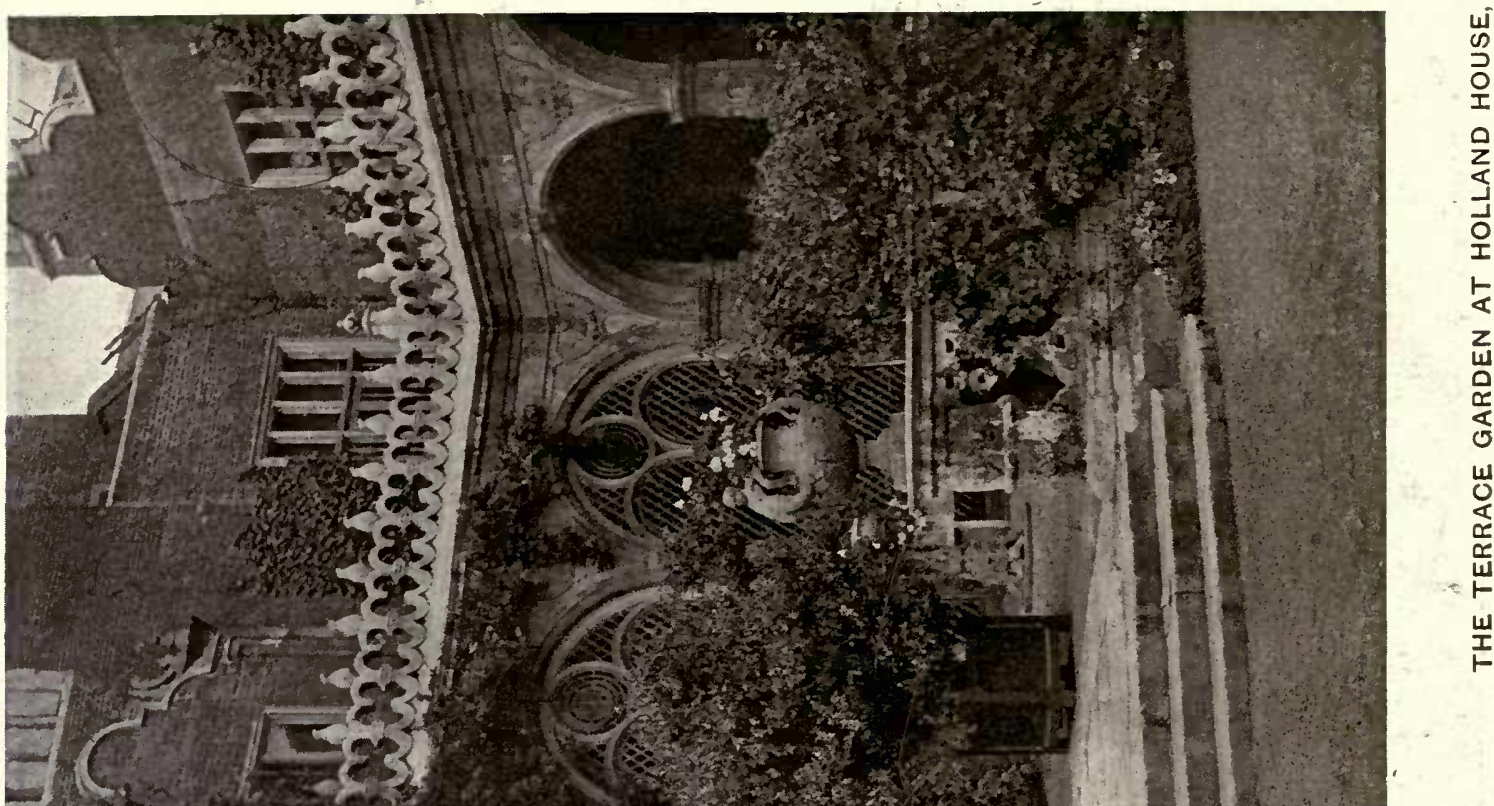

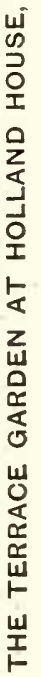

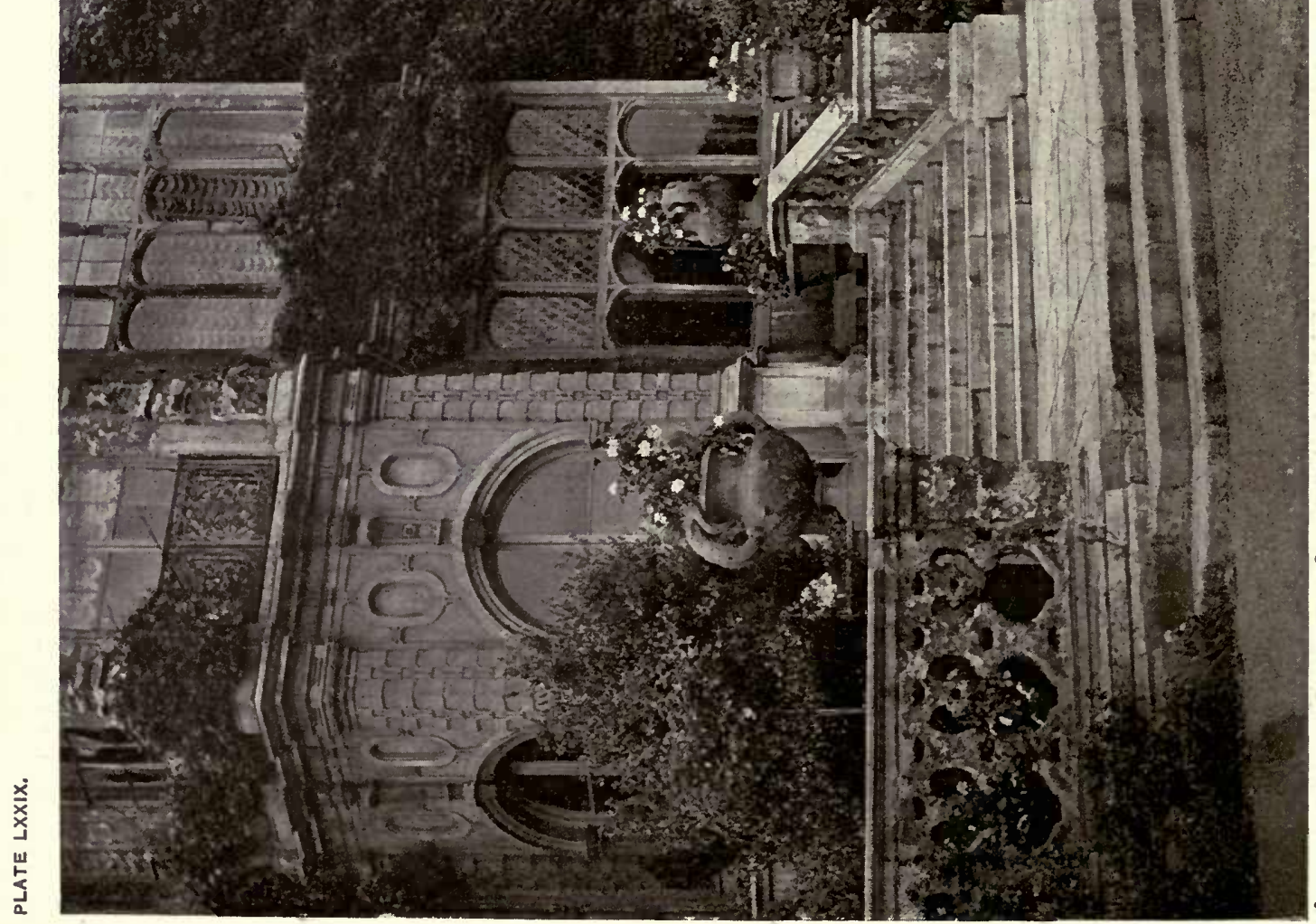

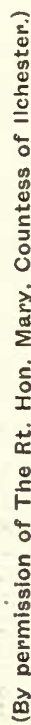




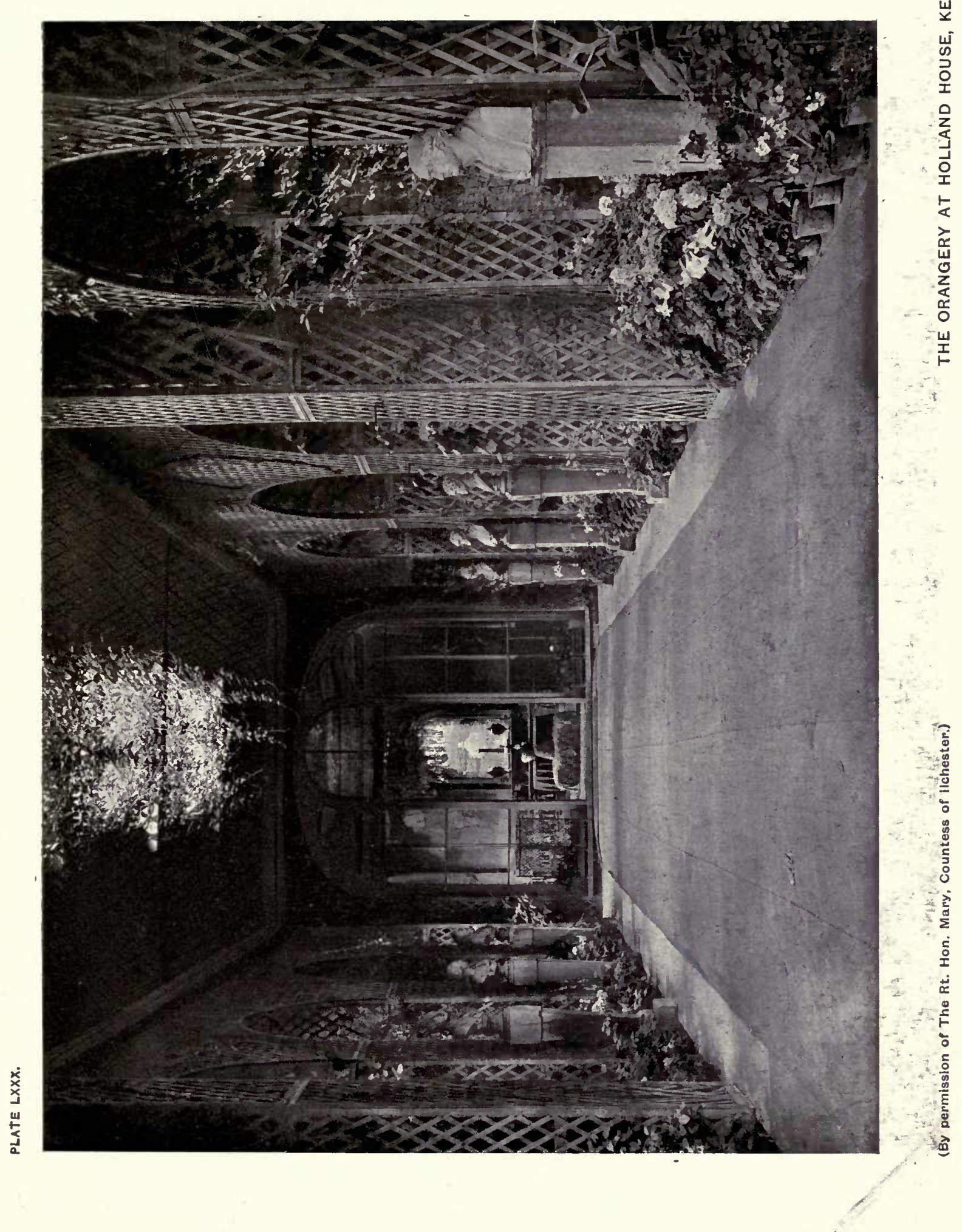




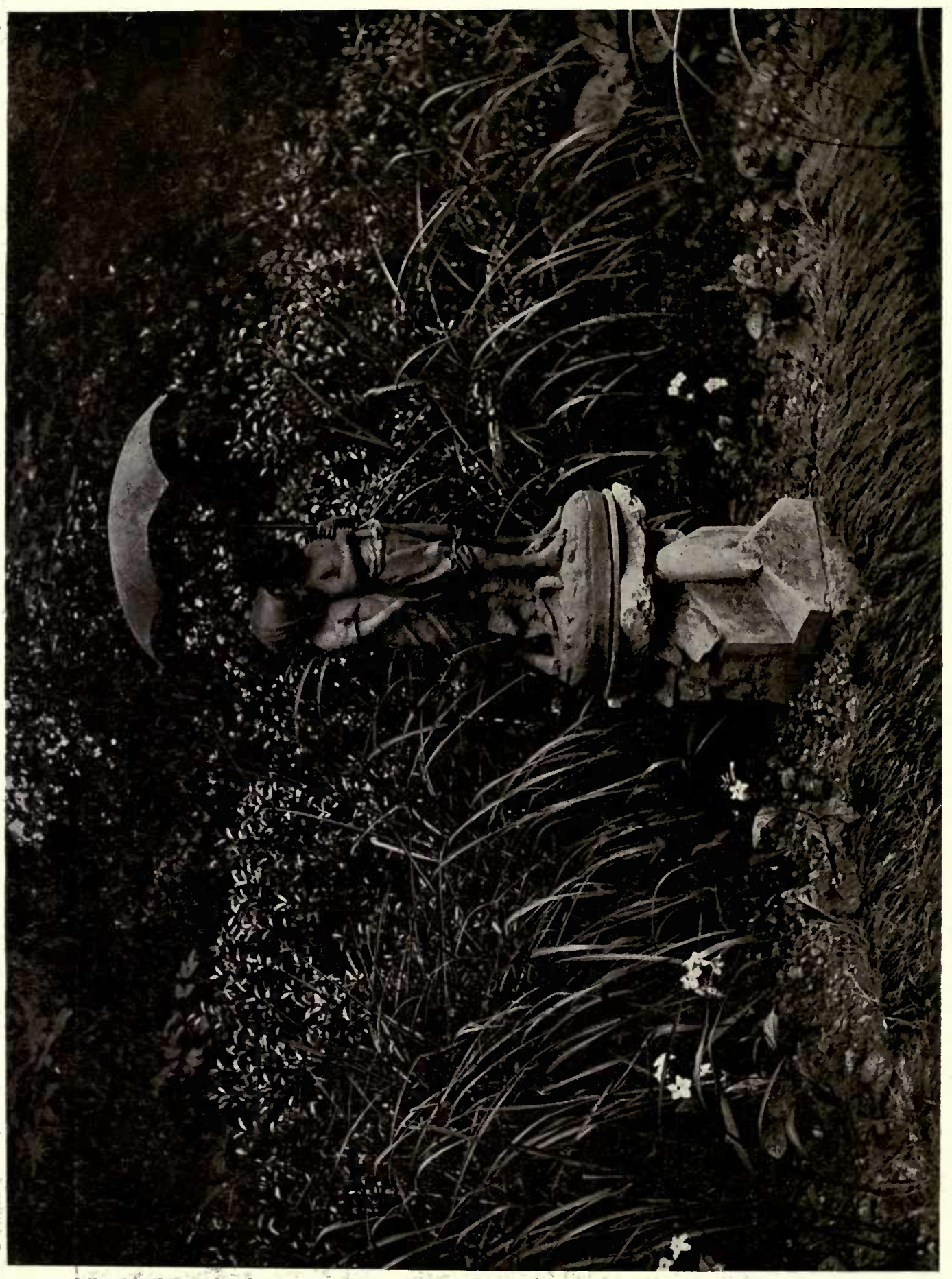





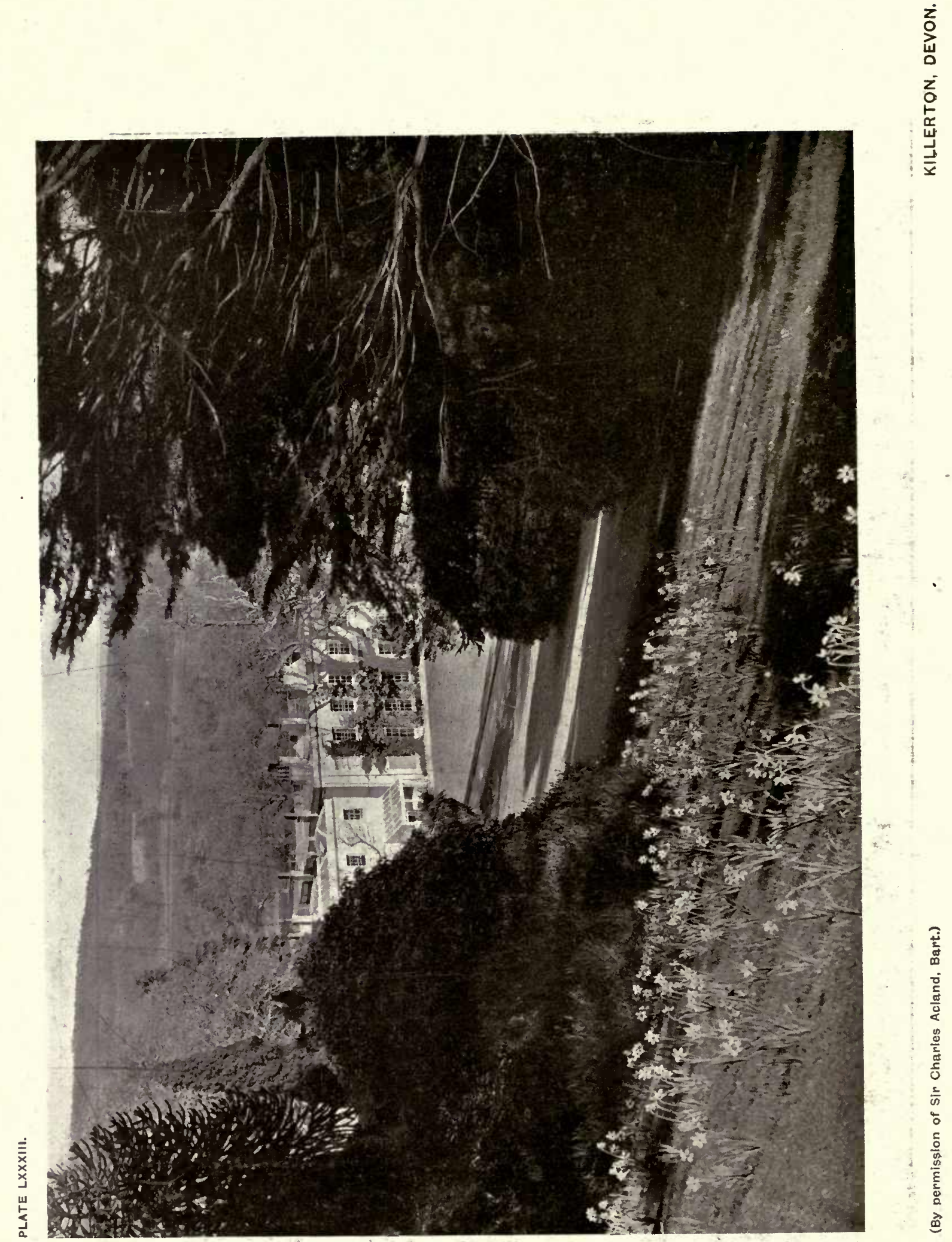




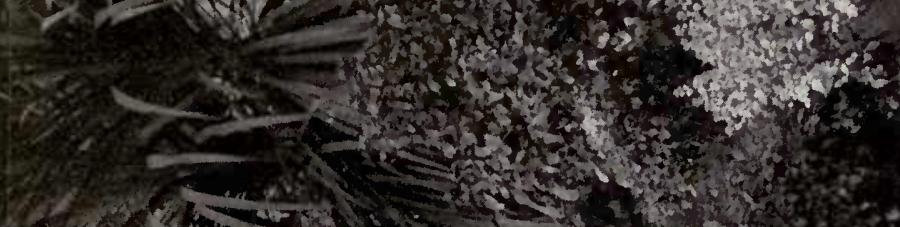

\section{H.}

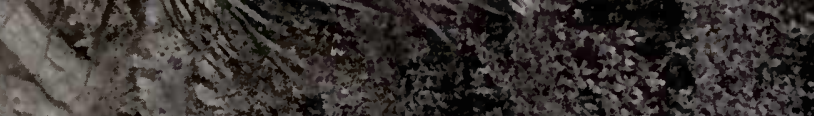

- 1 ind

30 (3)

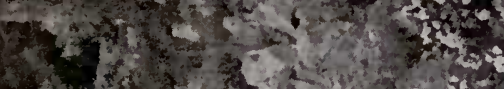

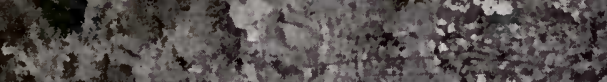

712
4

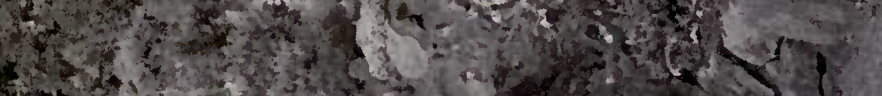

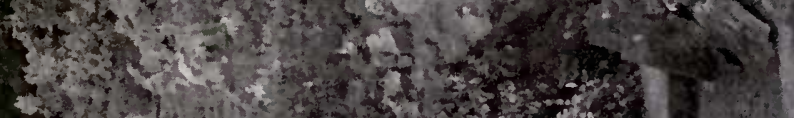

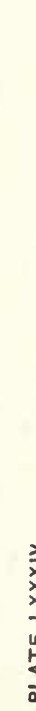

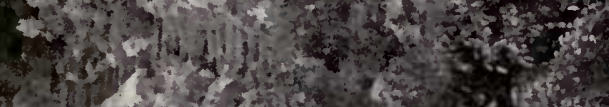

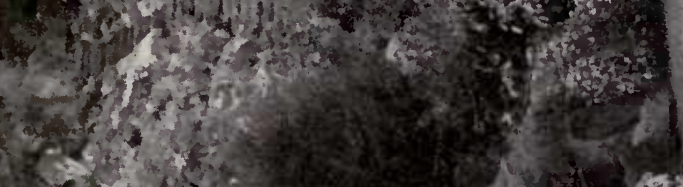

342
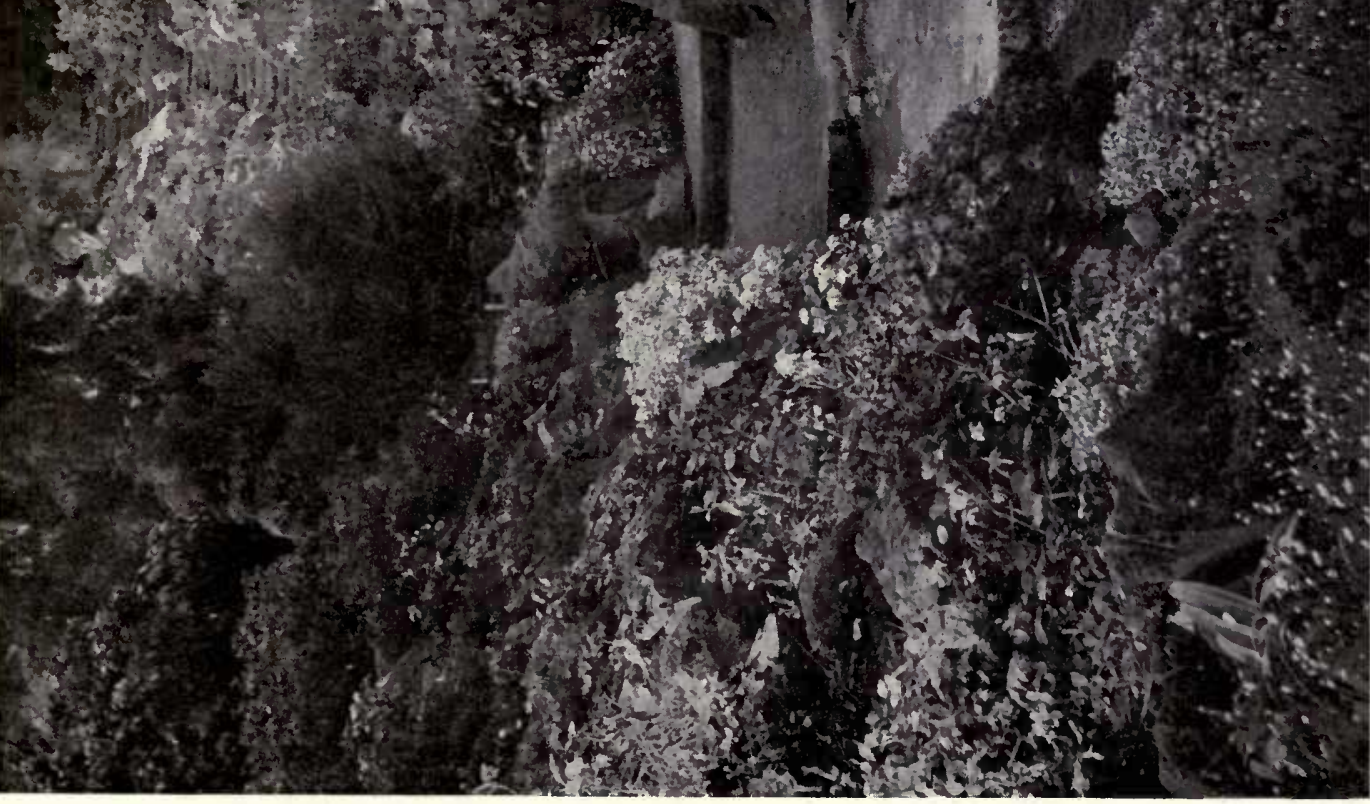


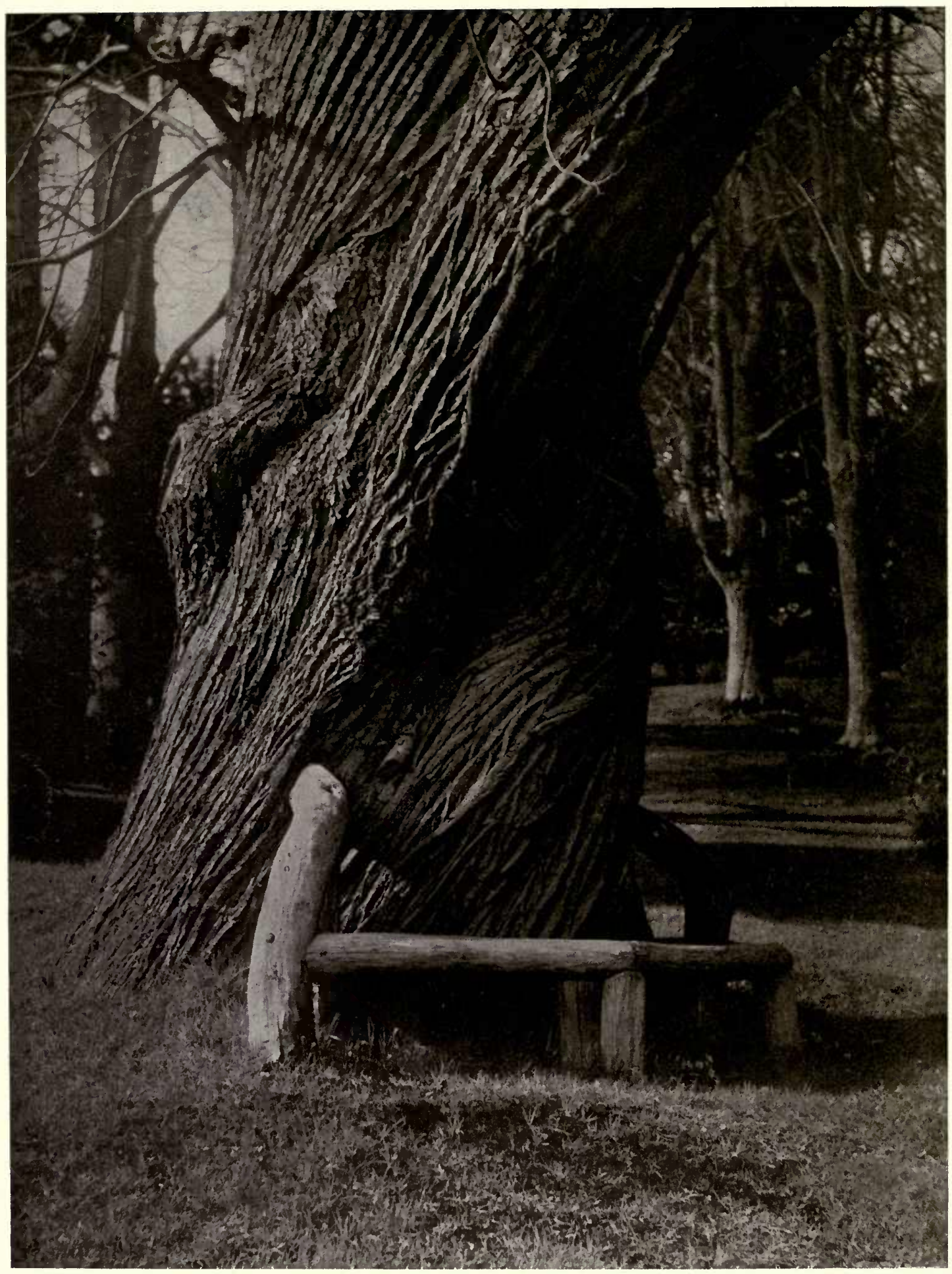




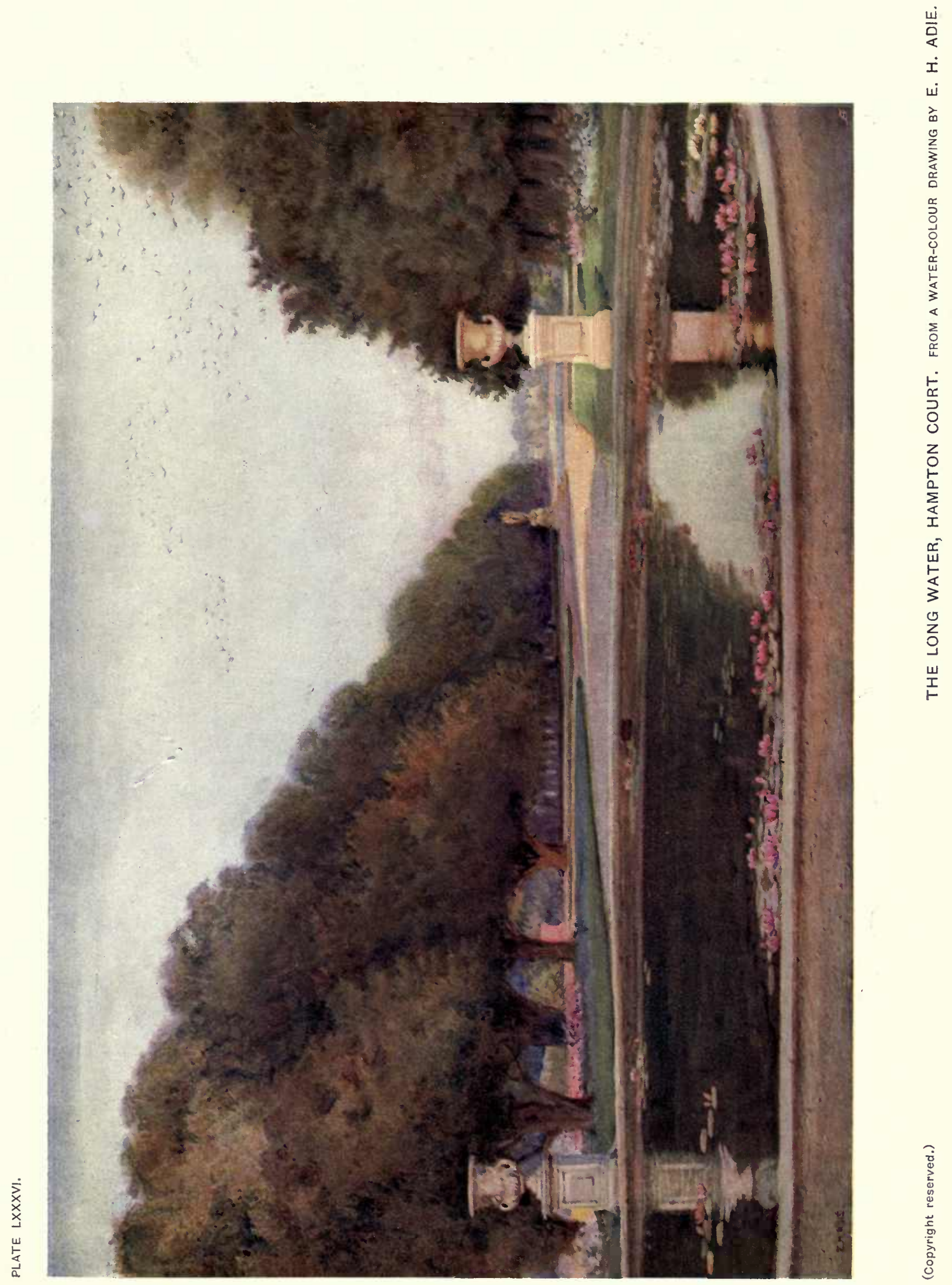




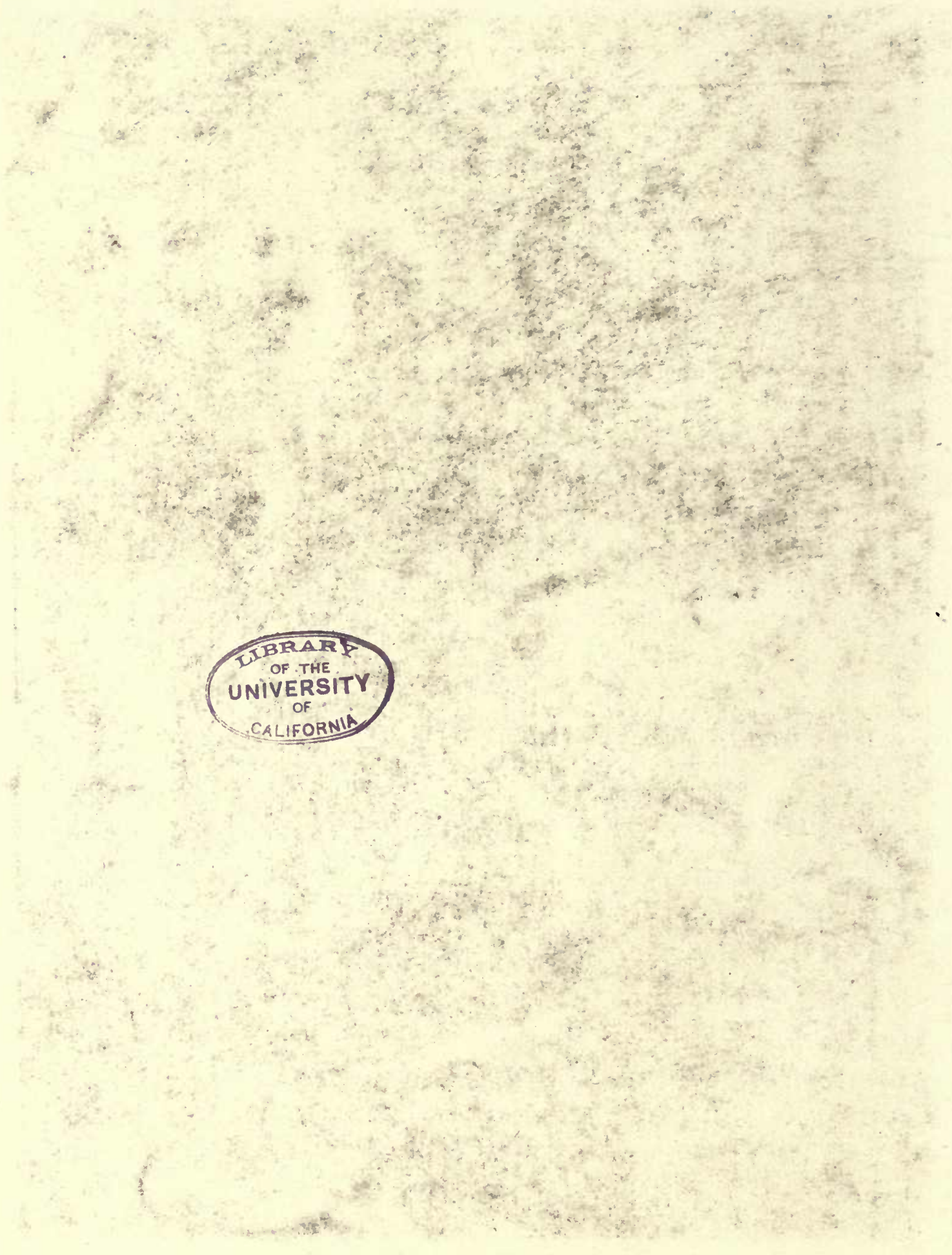




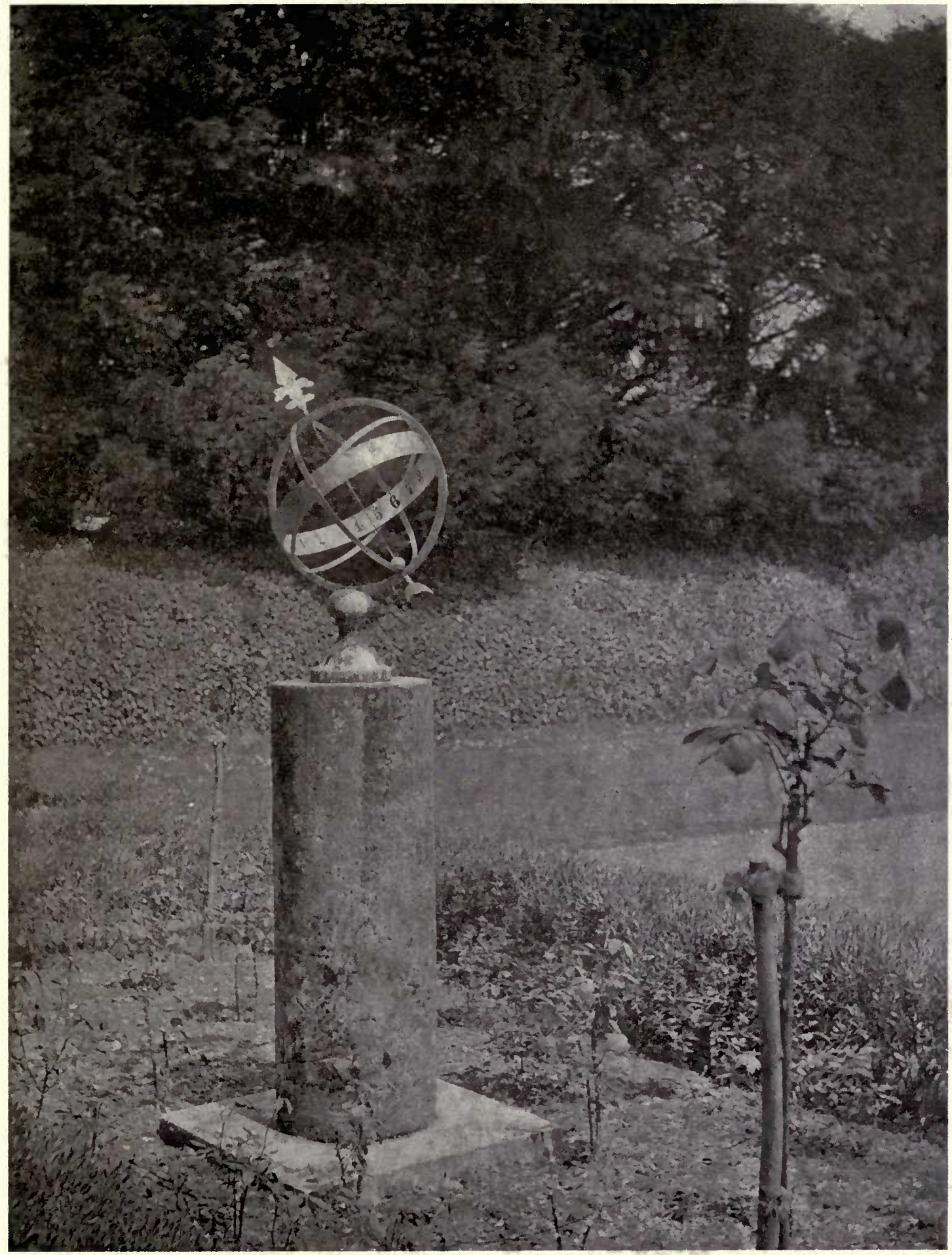




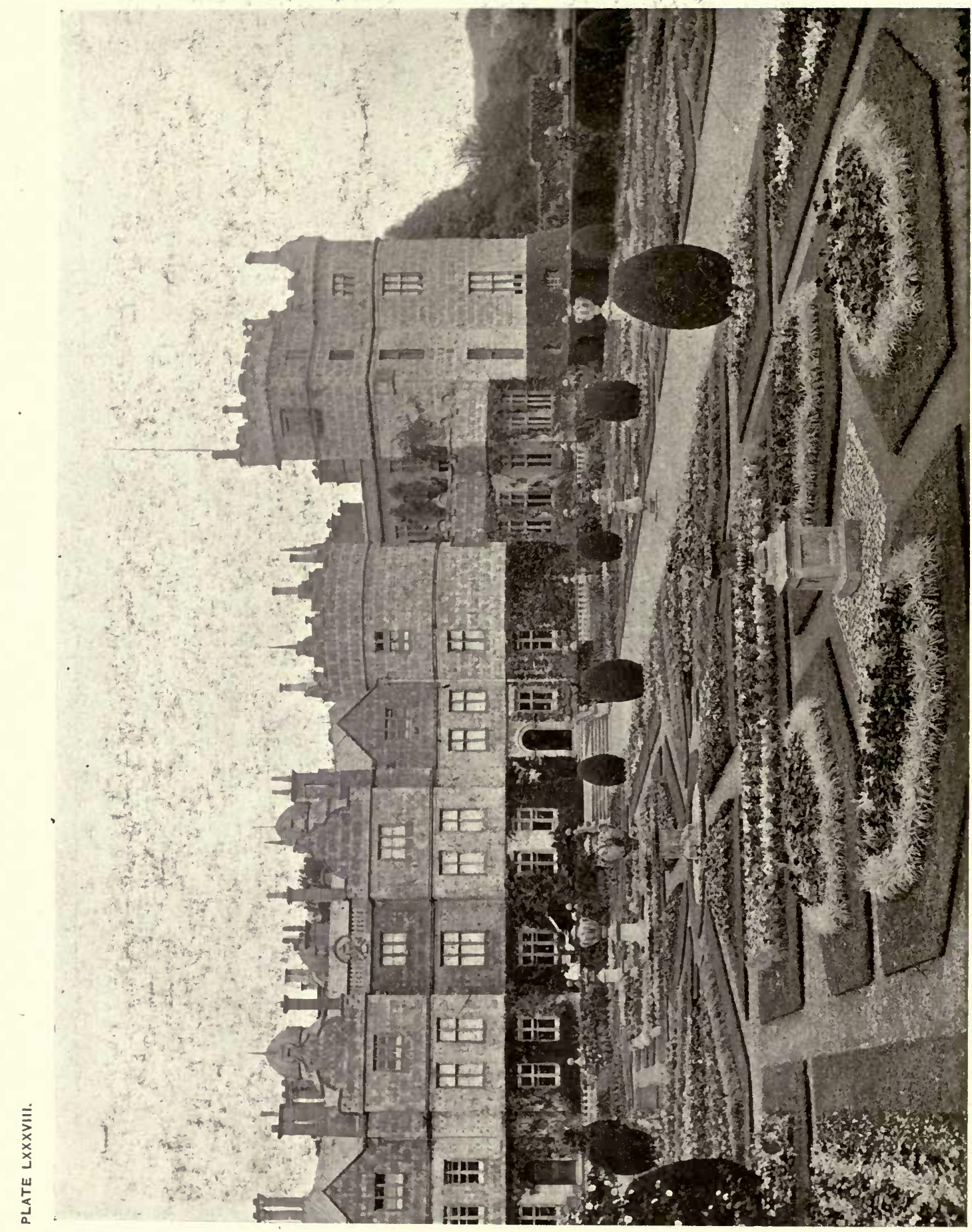

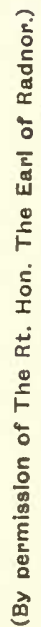




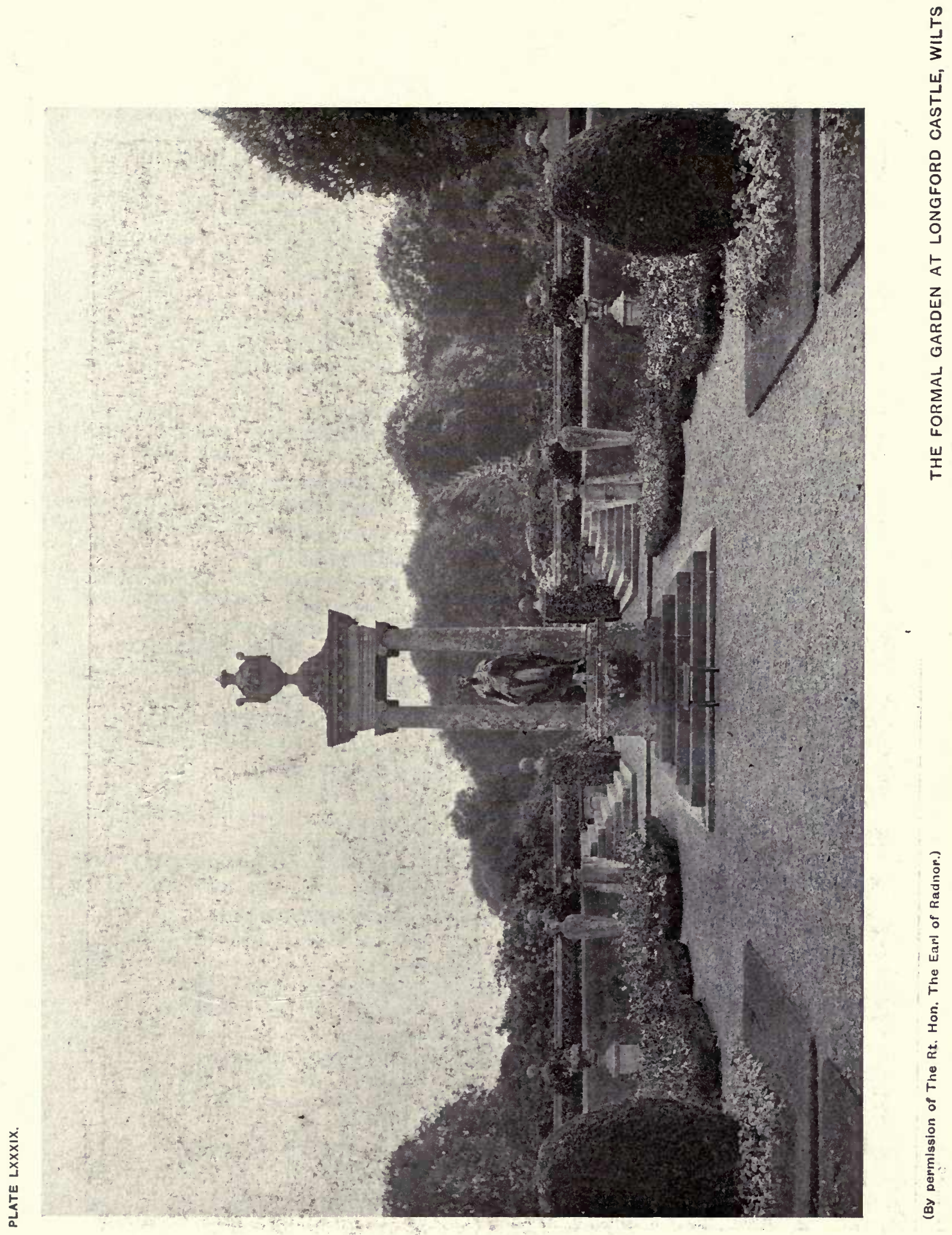




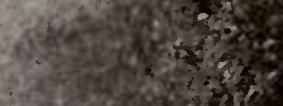
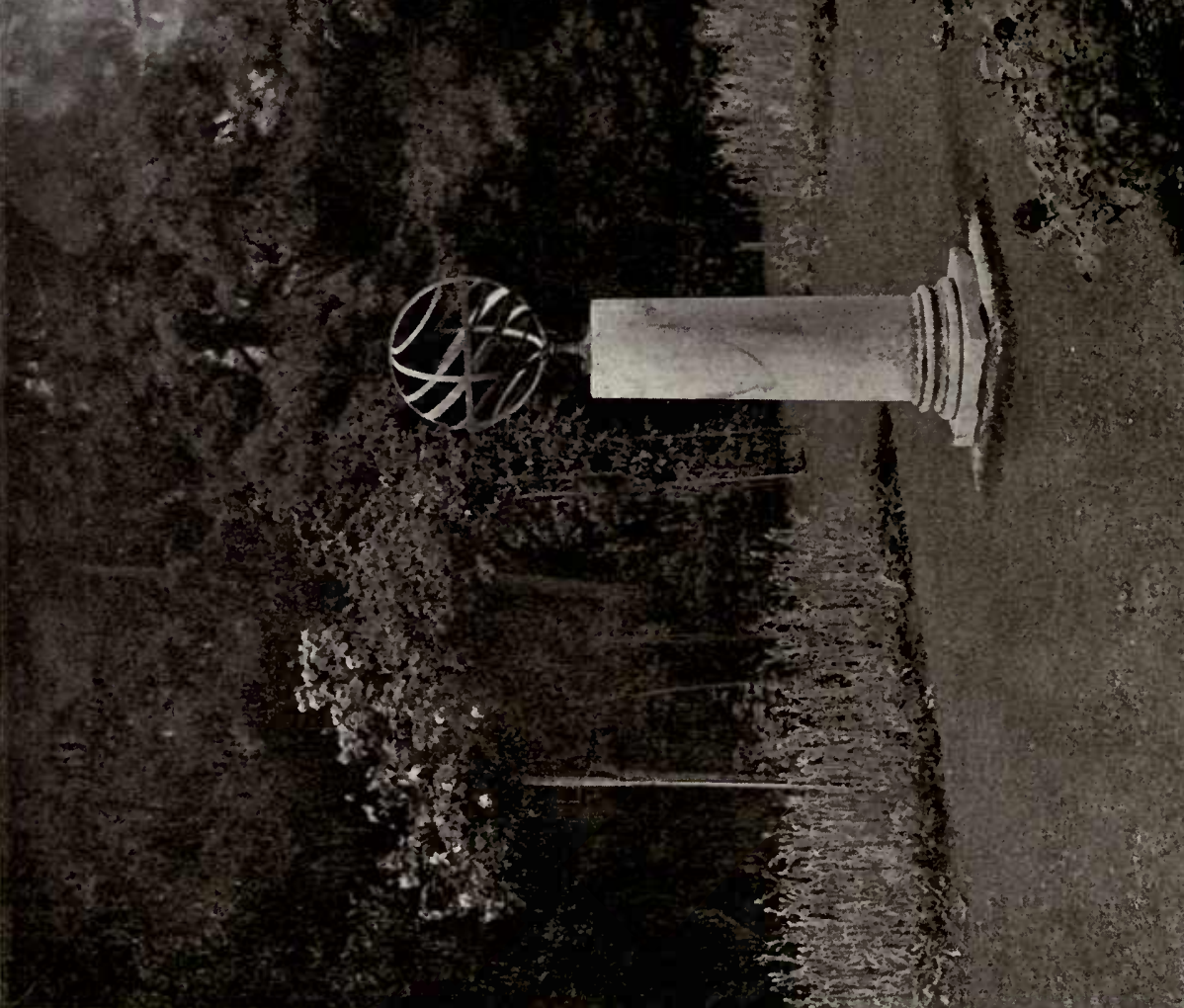


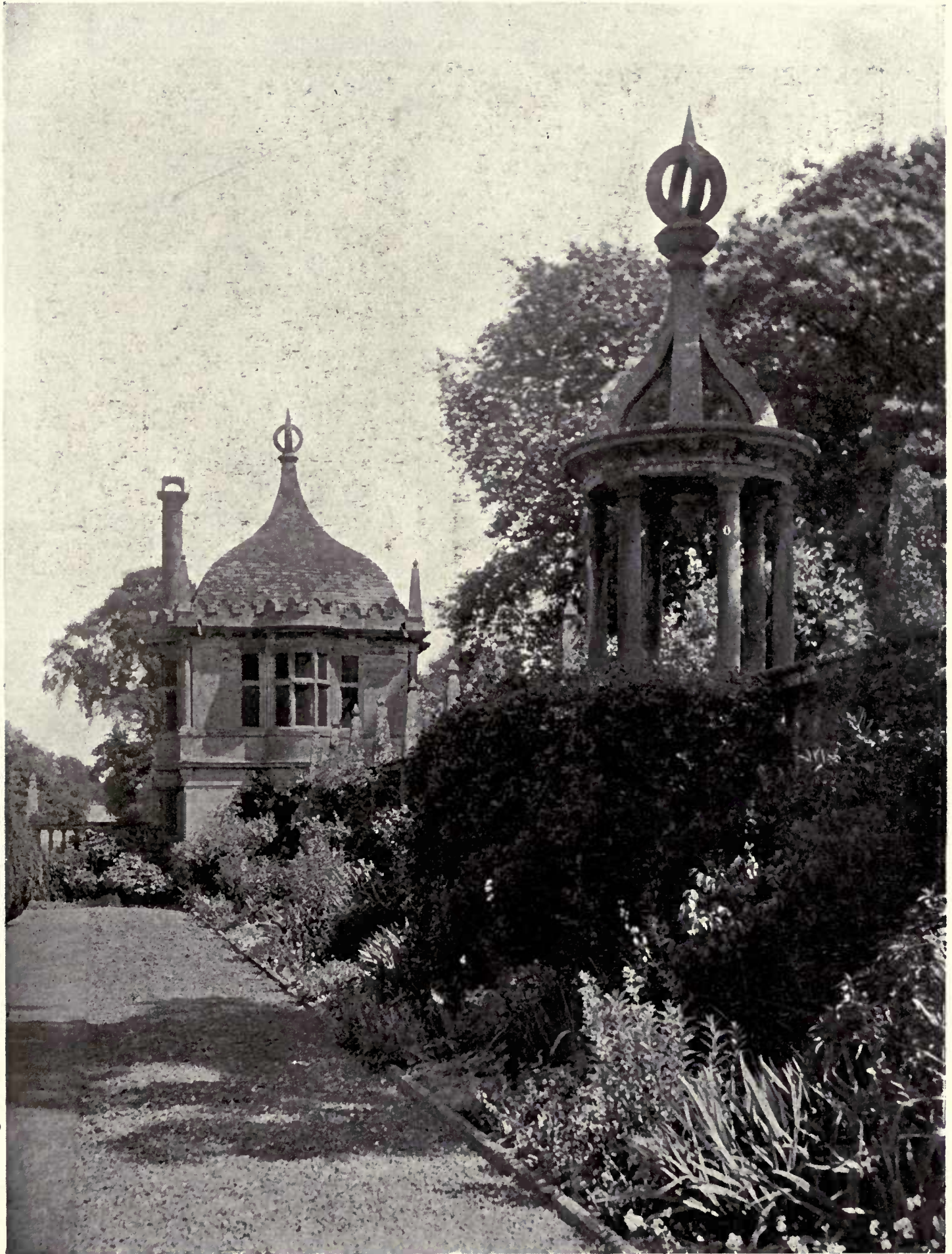




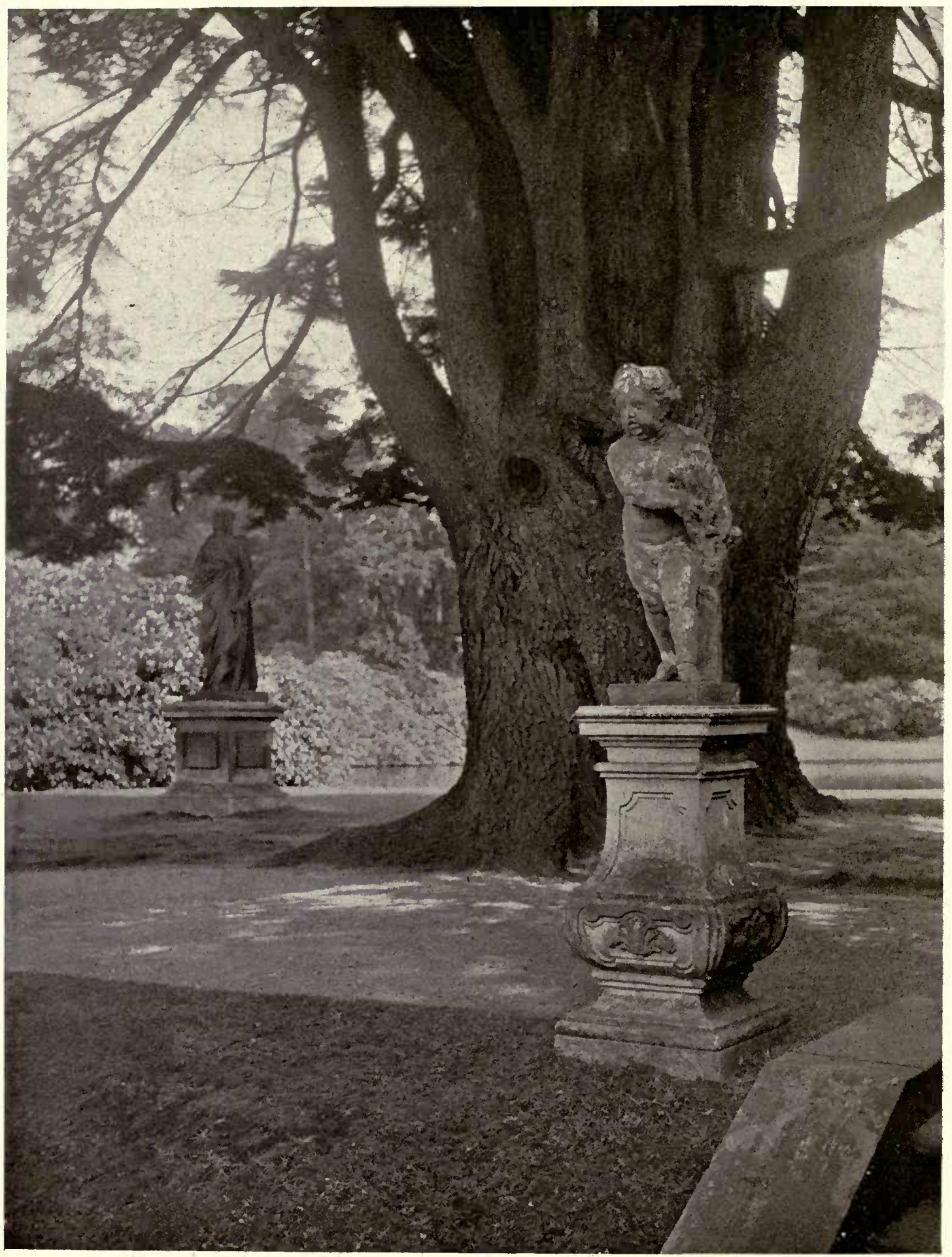




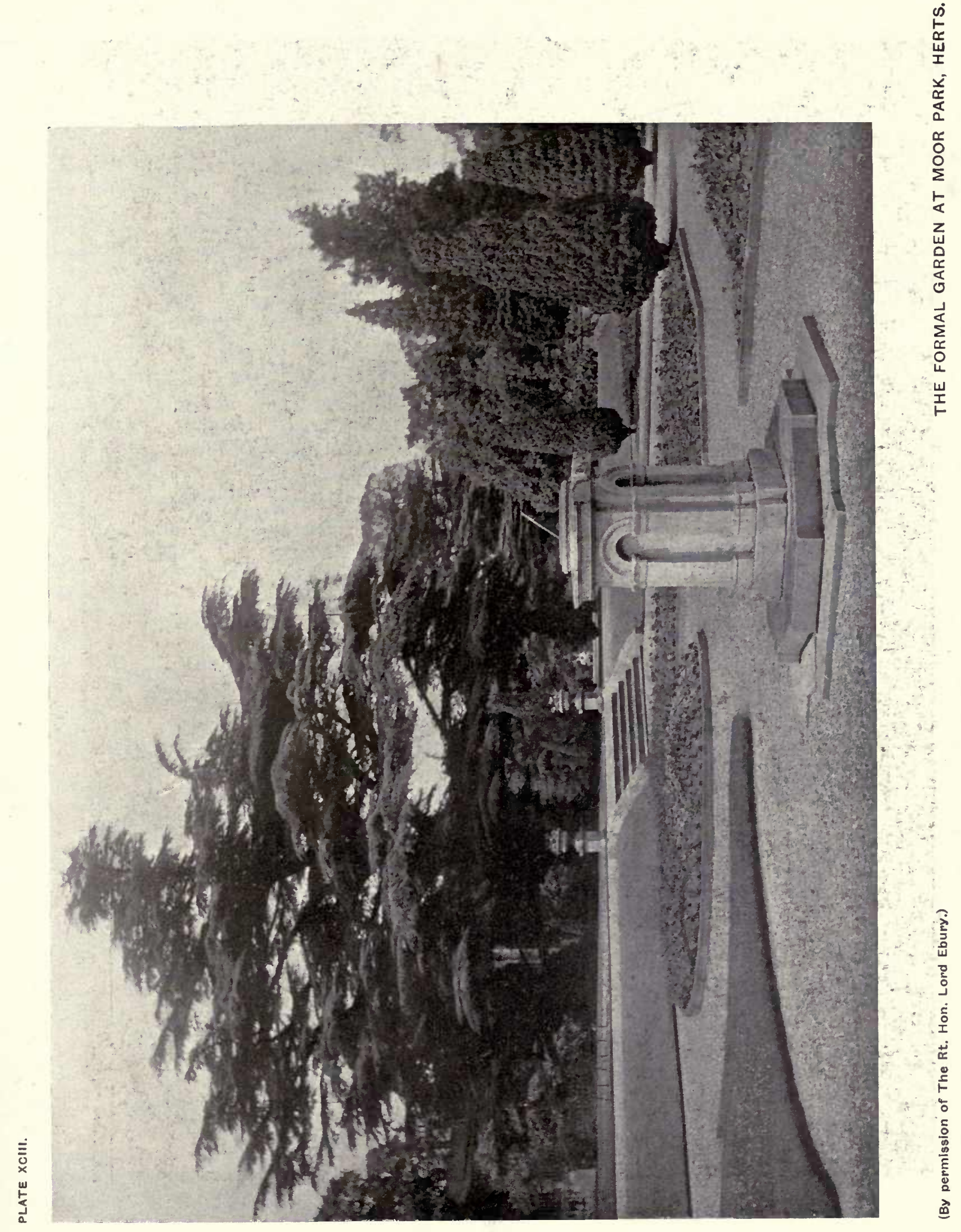




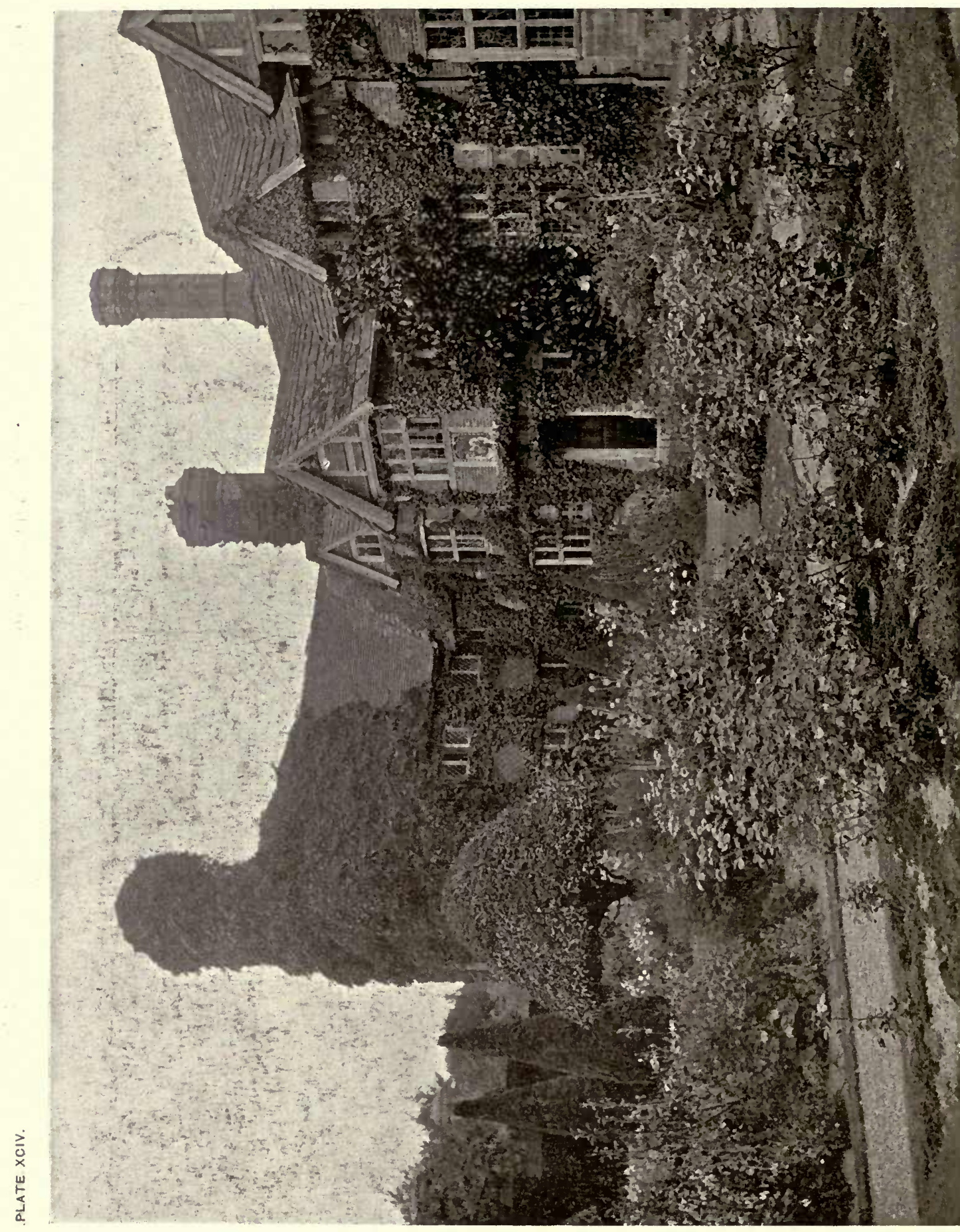




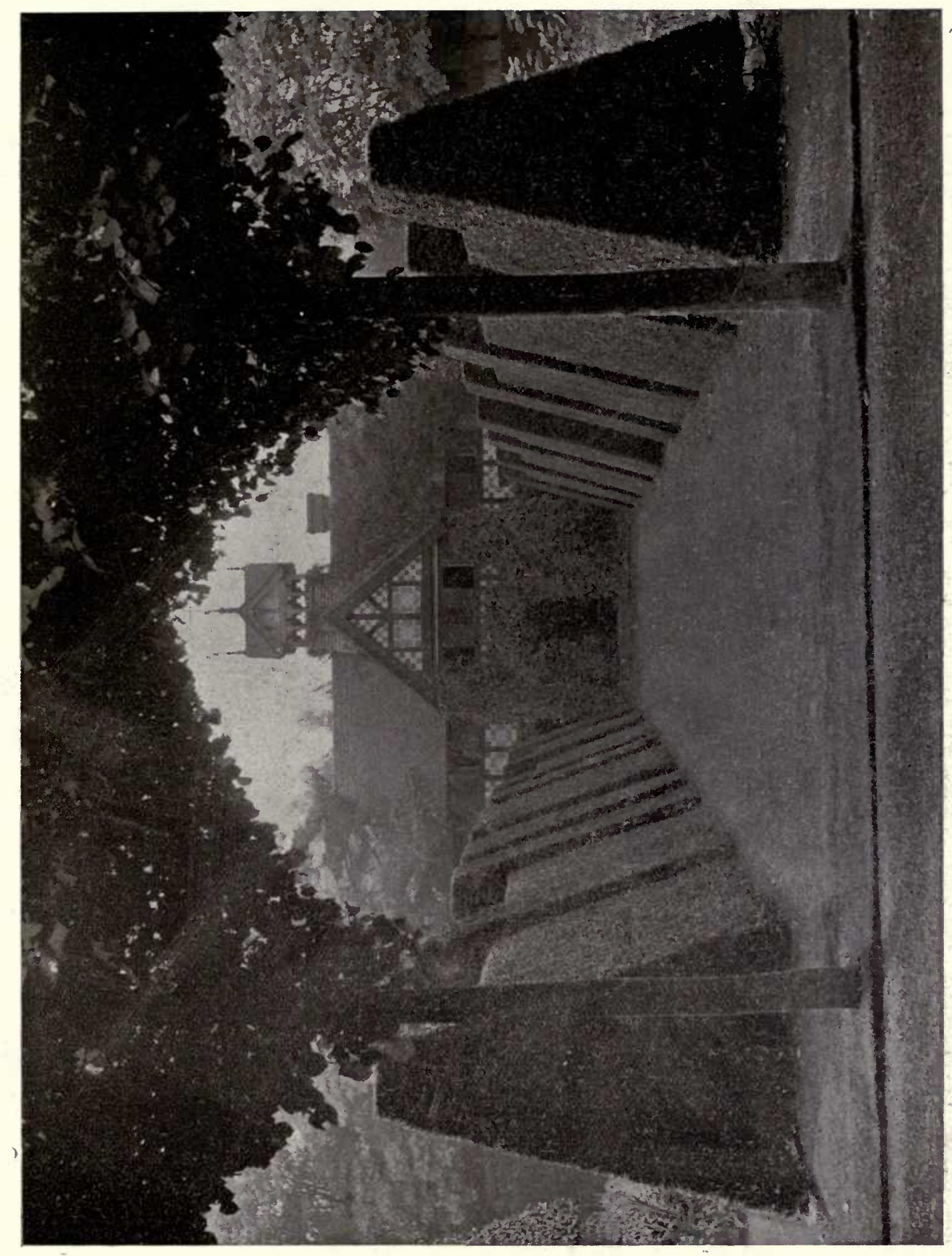




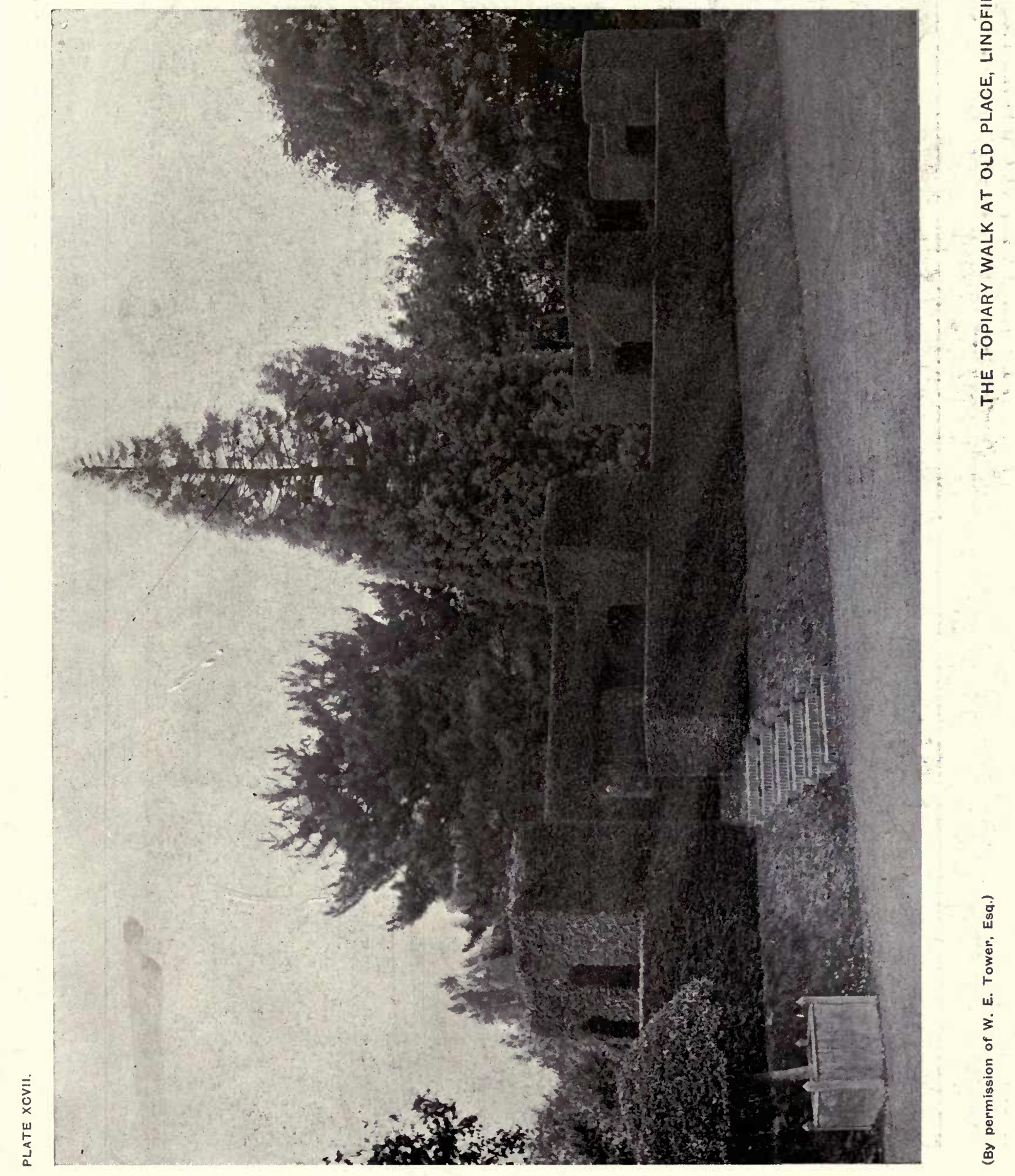




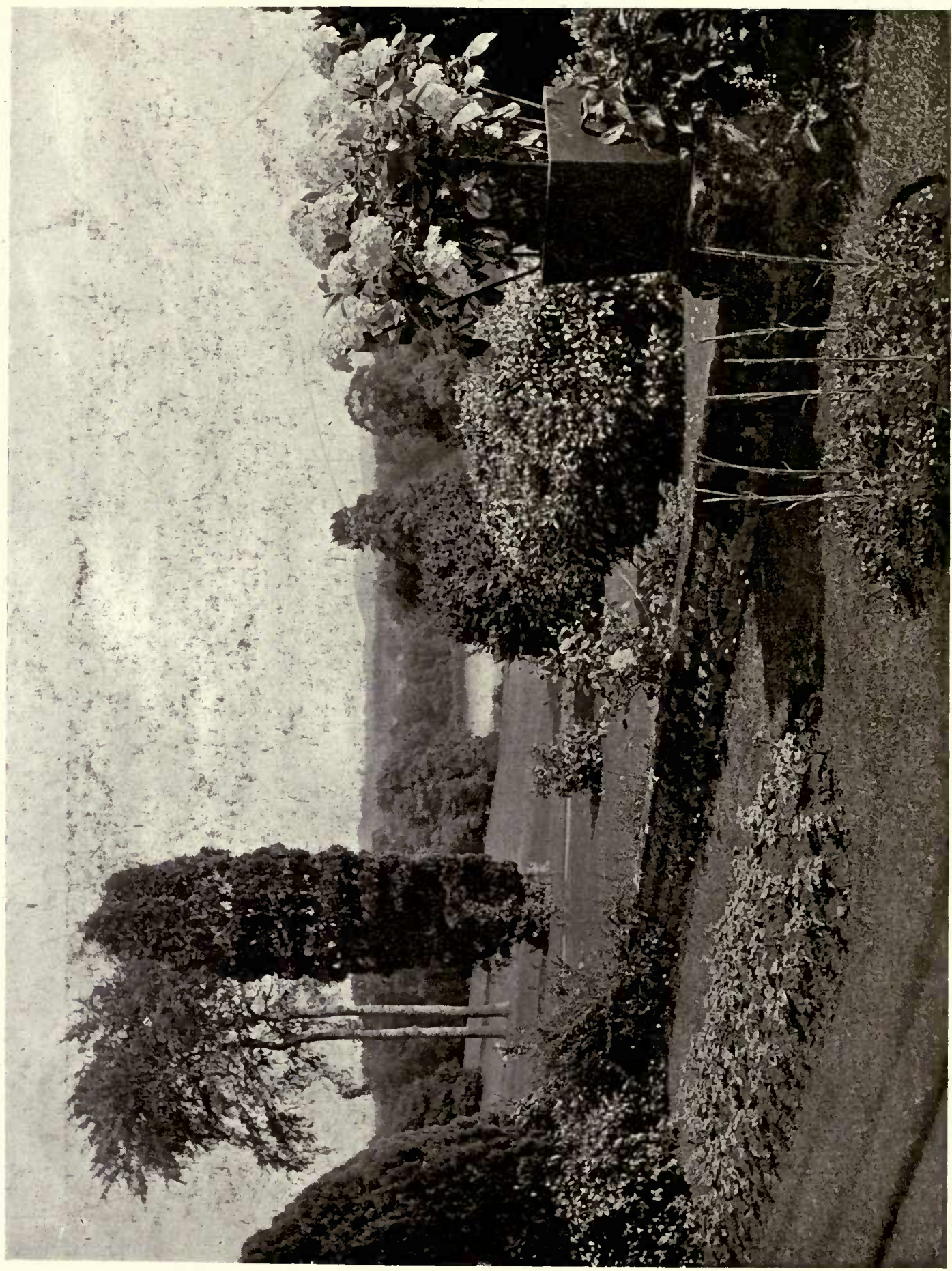




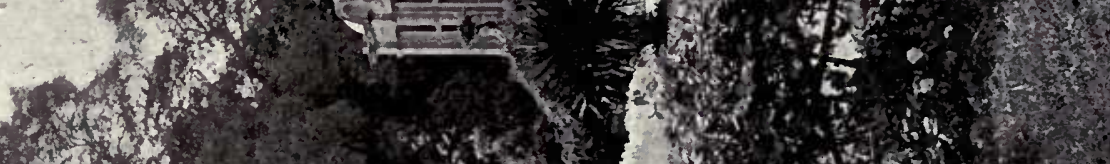
(1)

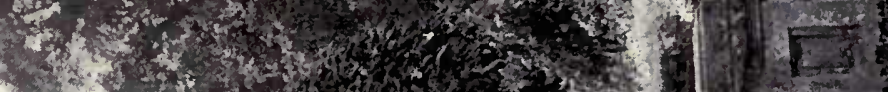

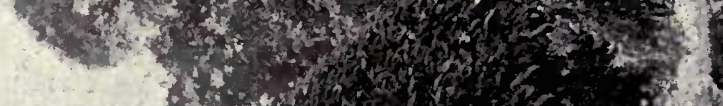

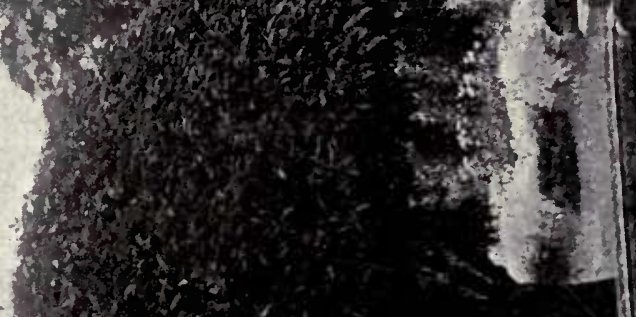




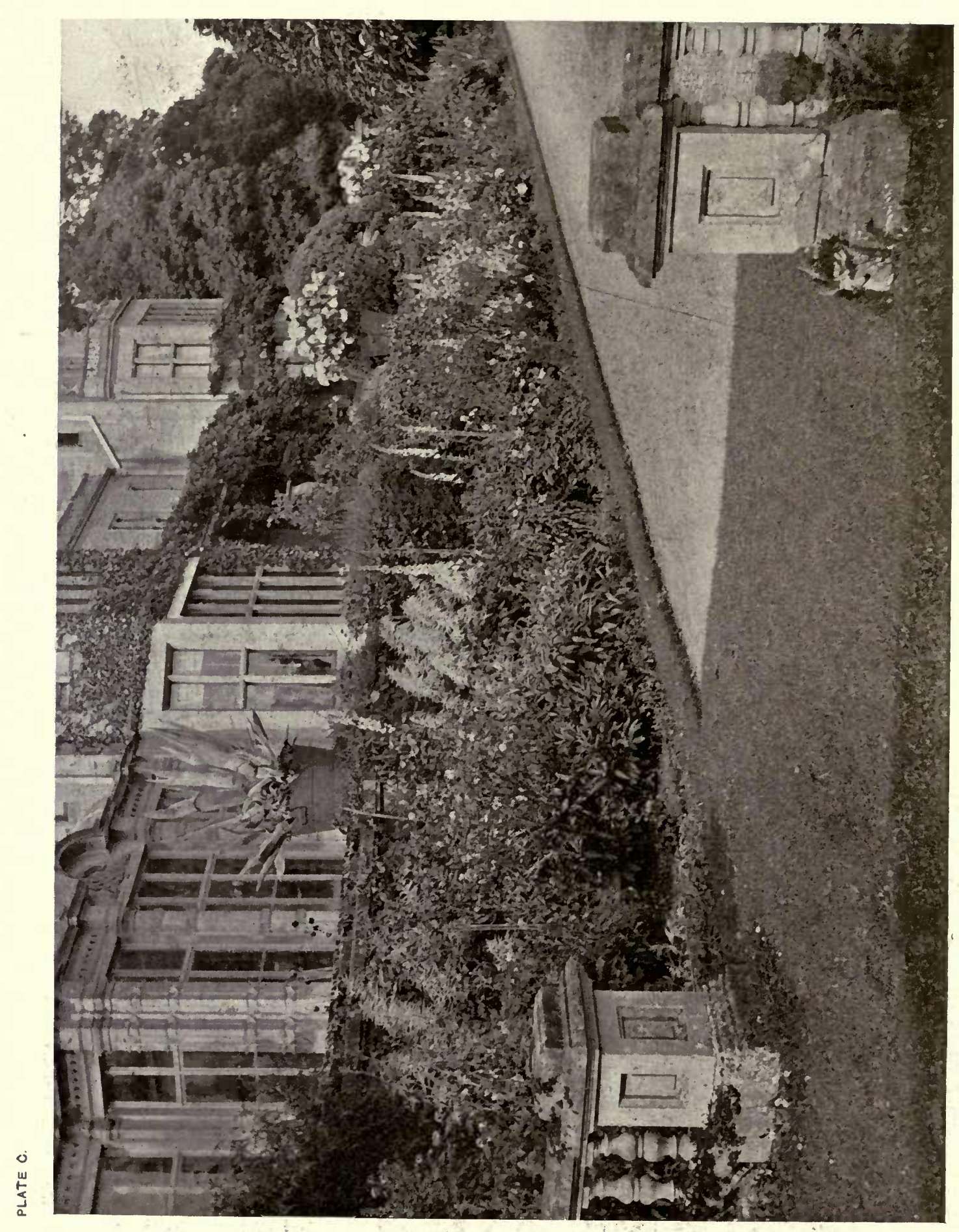

年 


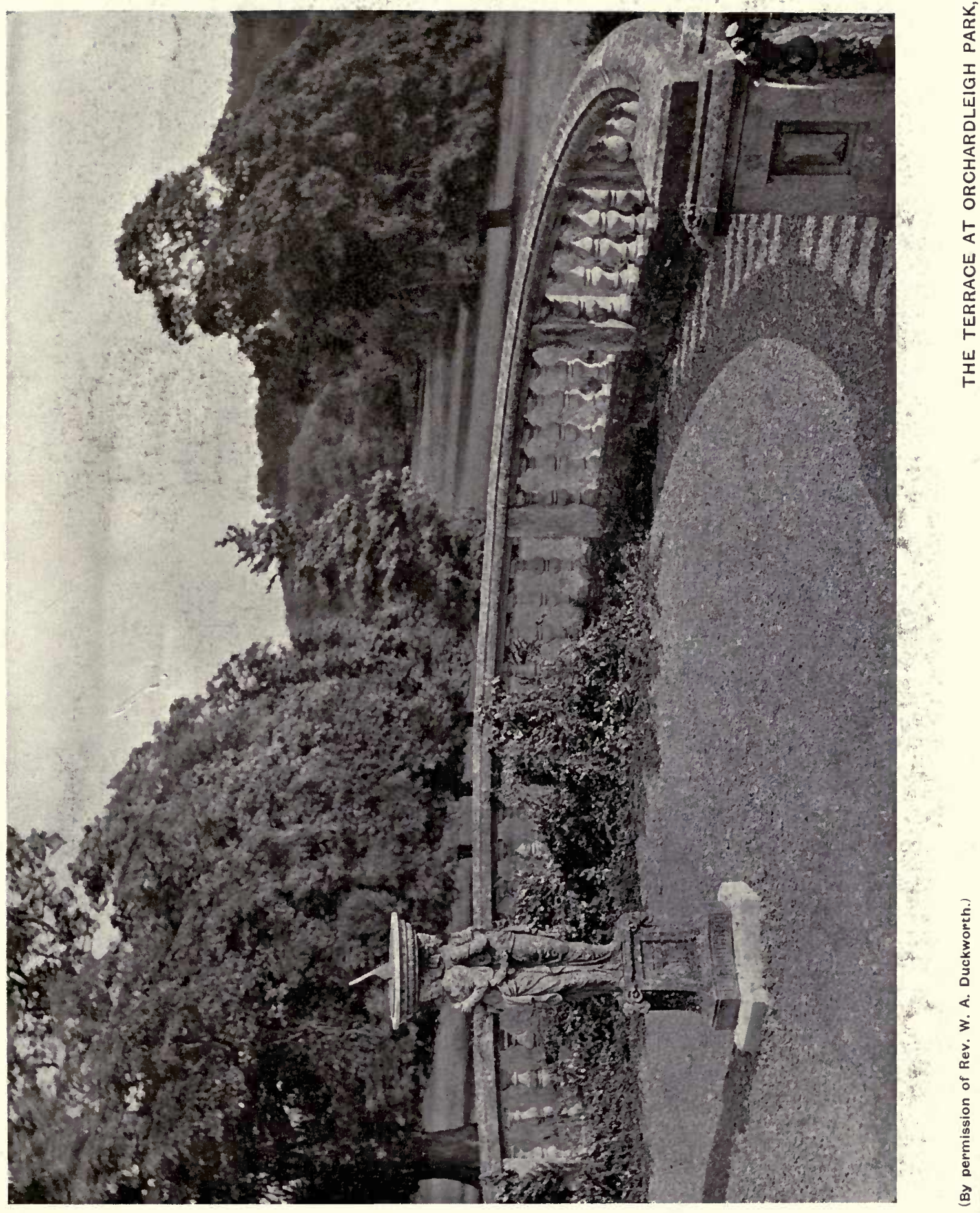




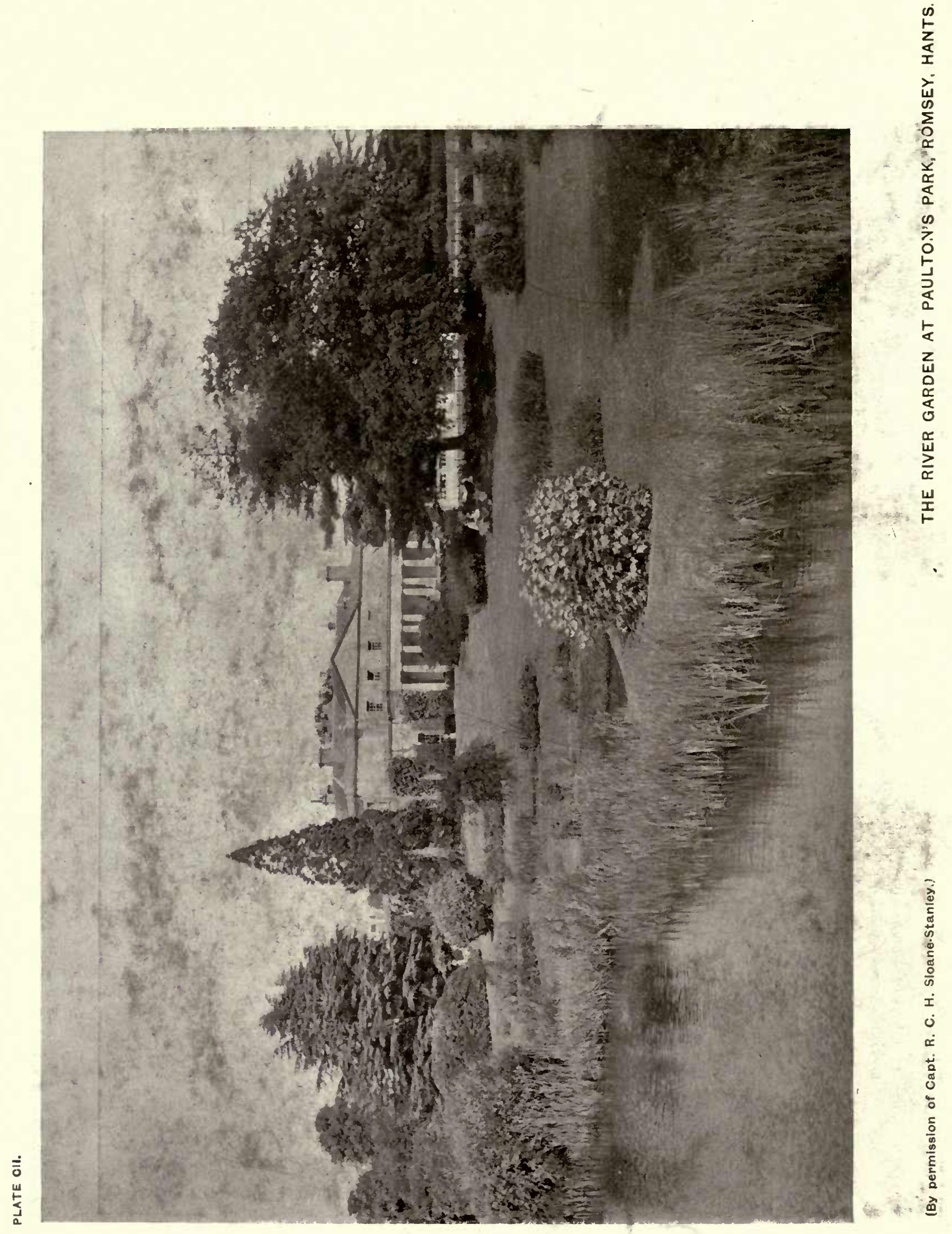




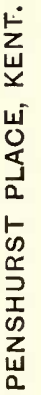

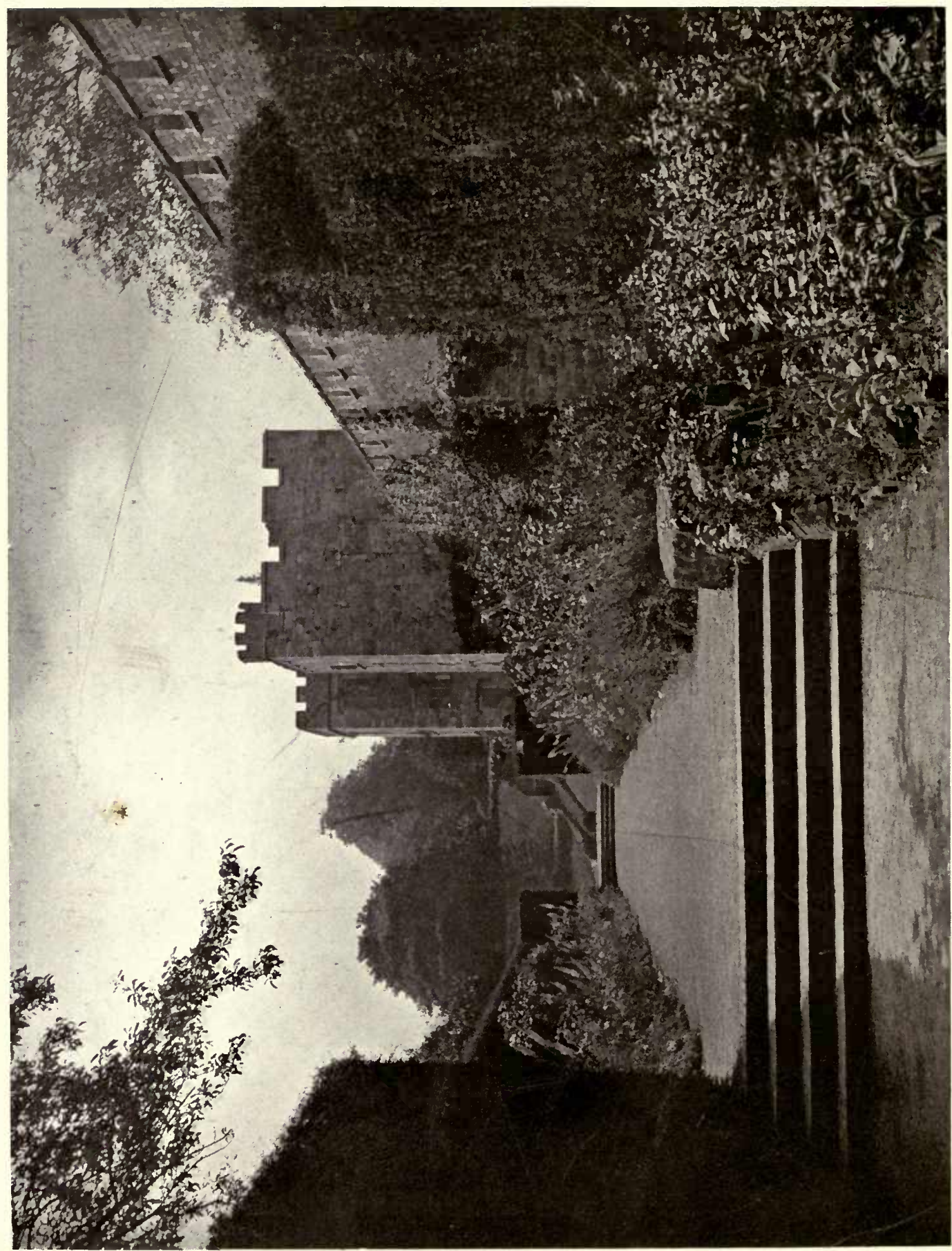

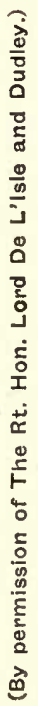




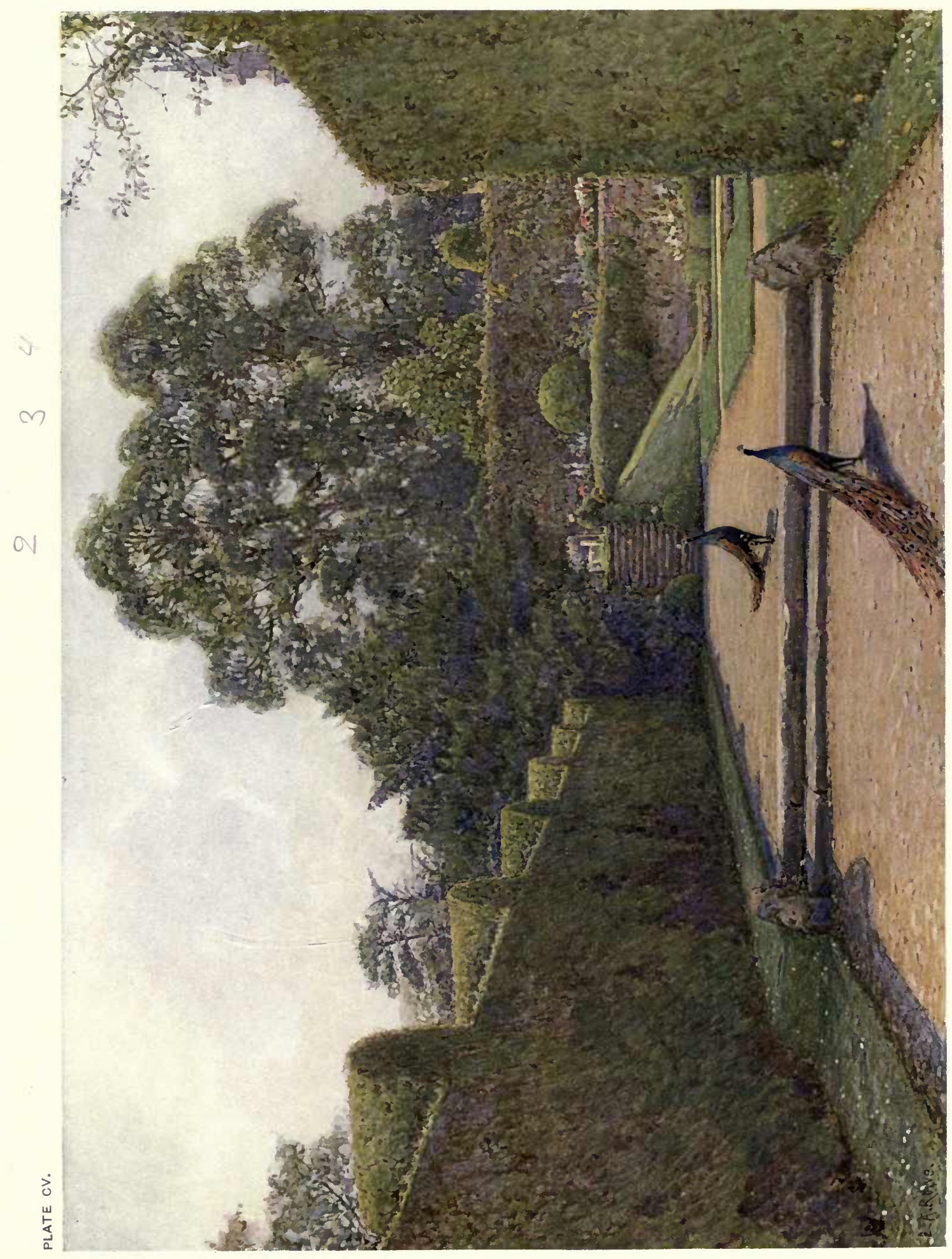




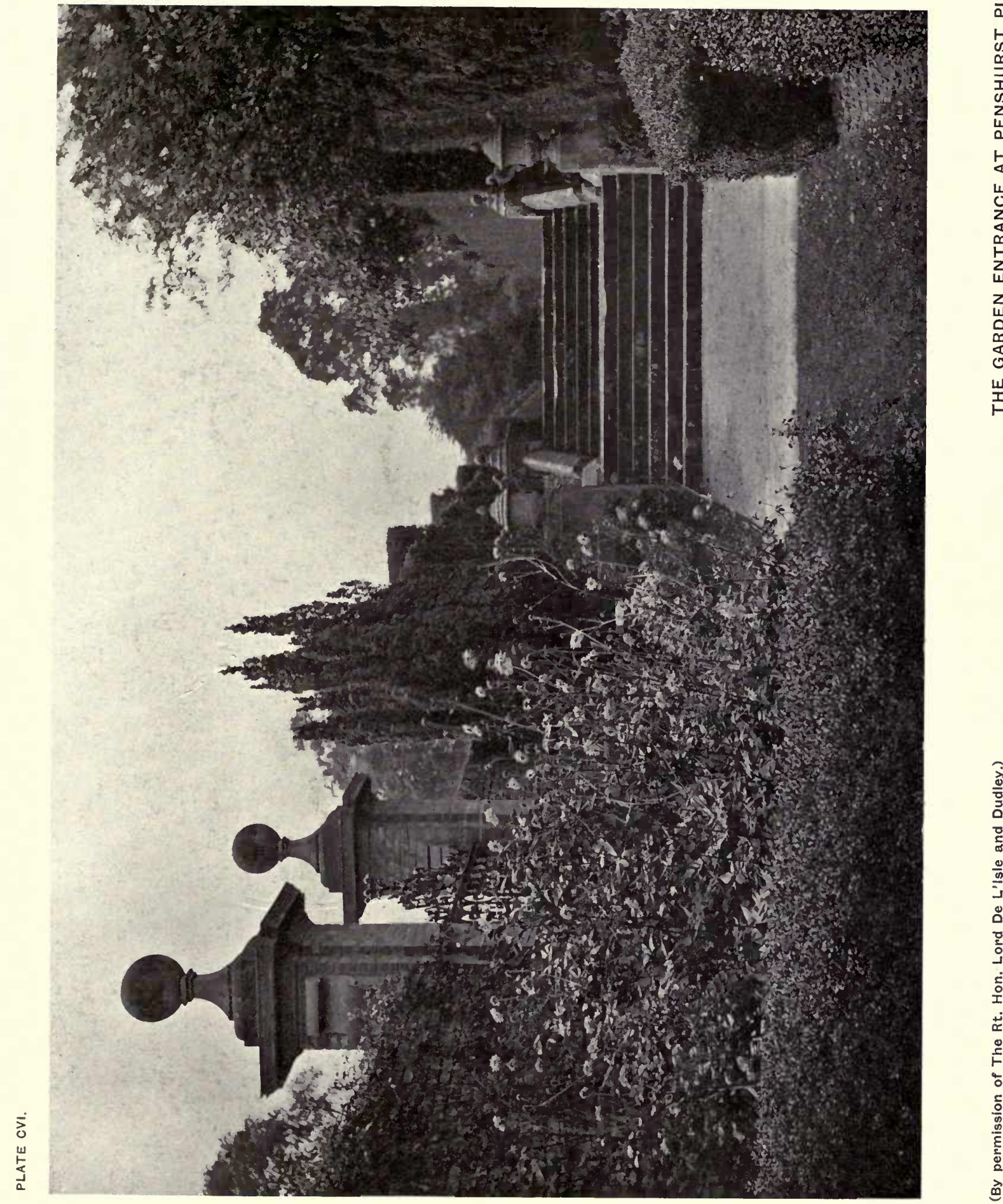

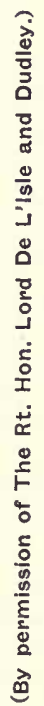




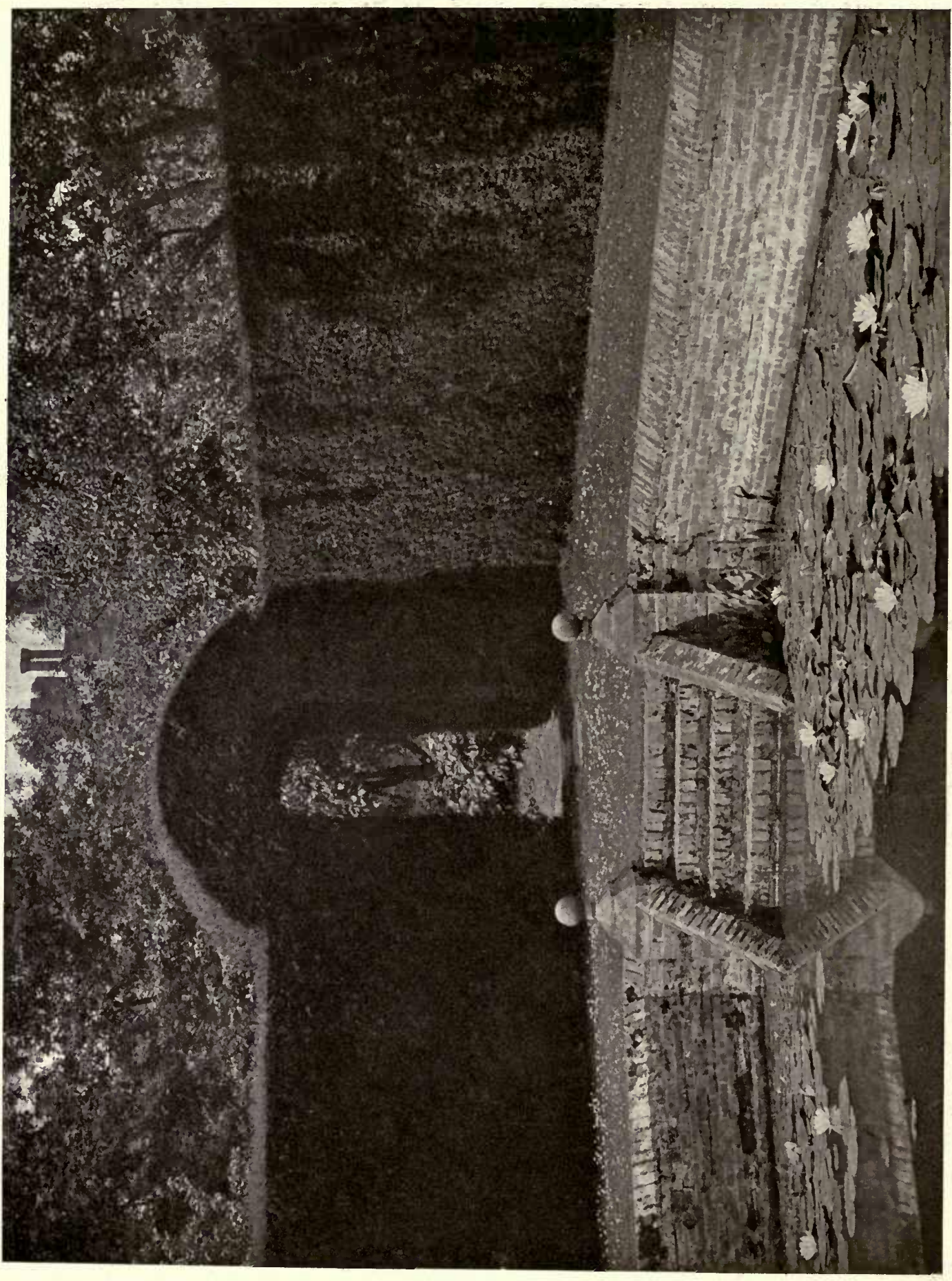




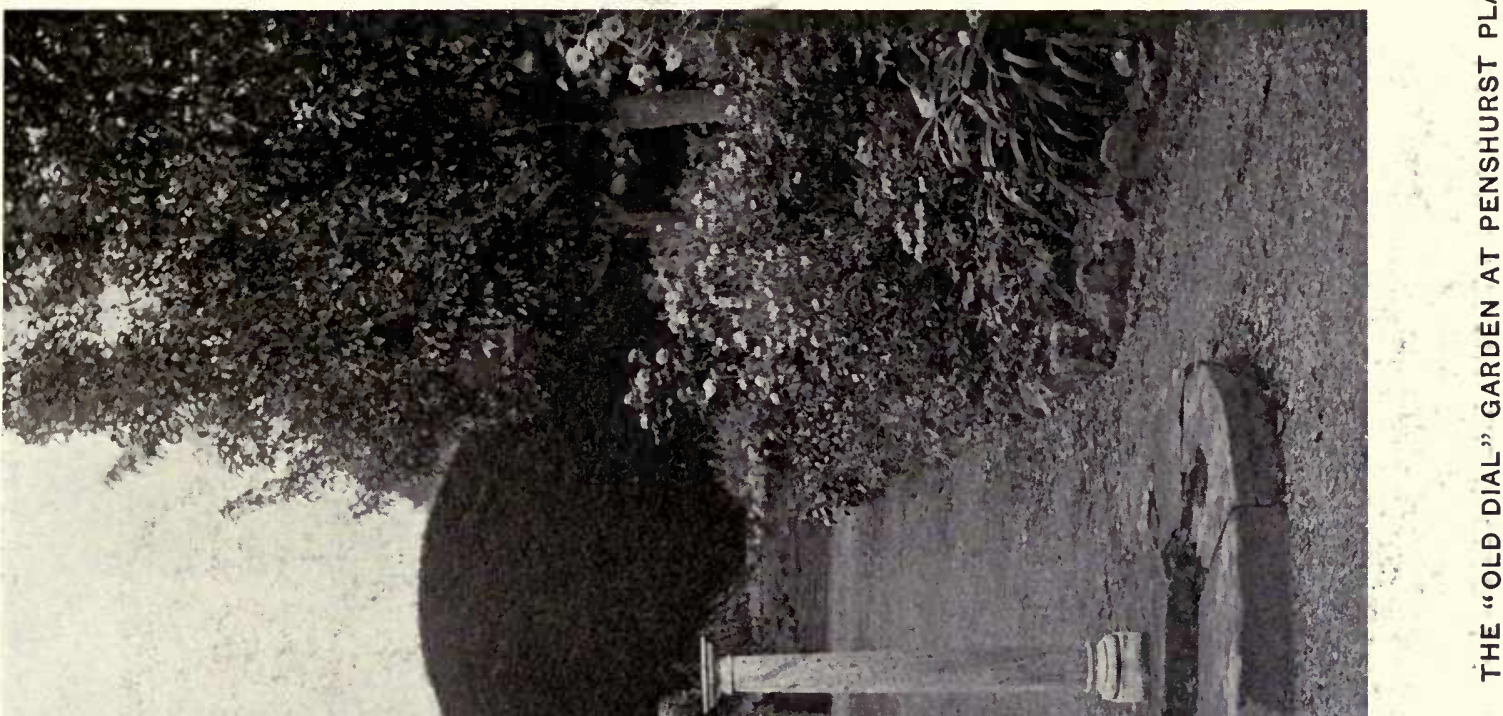

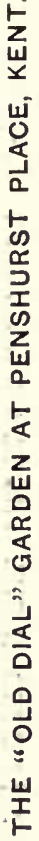

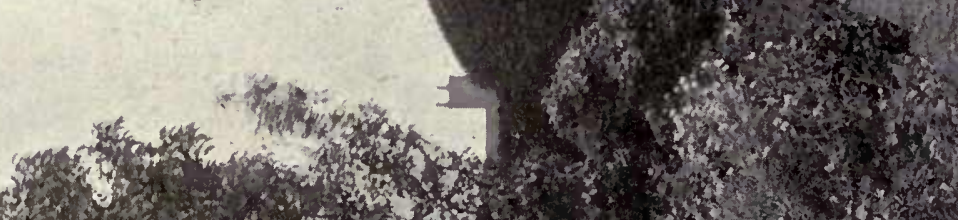

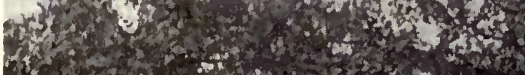
(3)

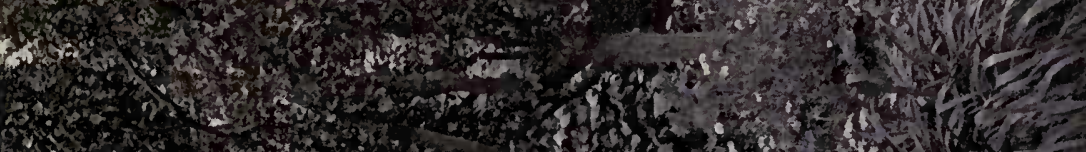

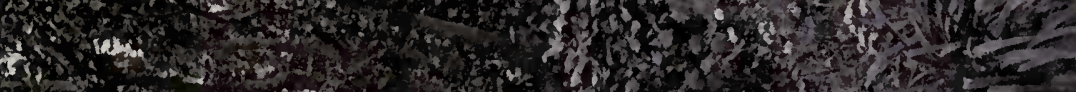

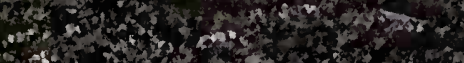

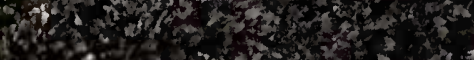

Stistist

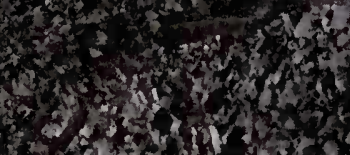

aty

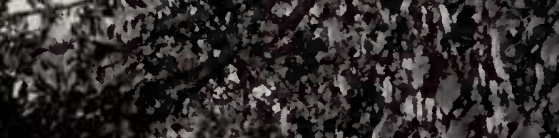

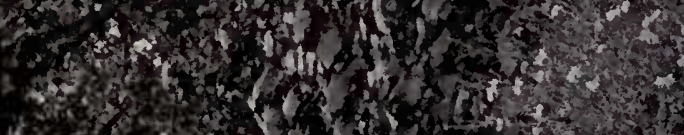

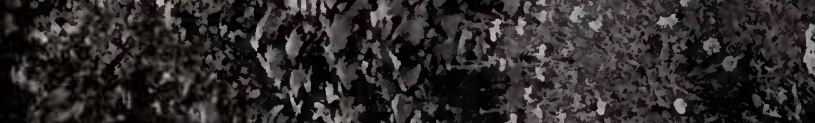
6. $10=$

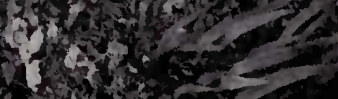
by alo $x^{2}$

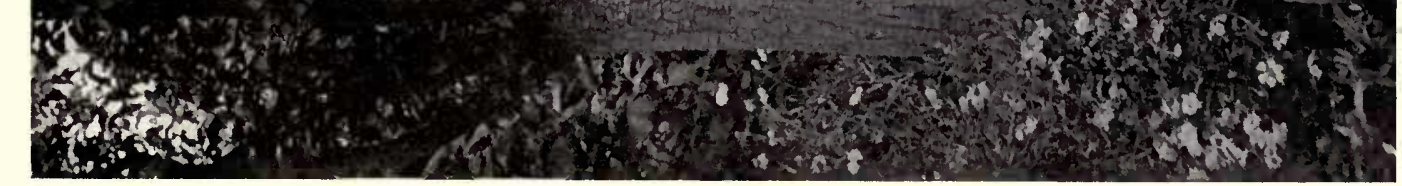




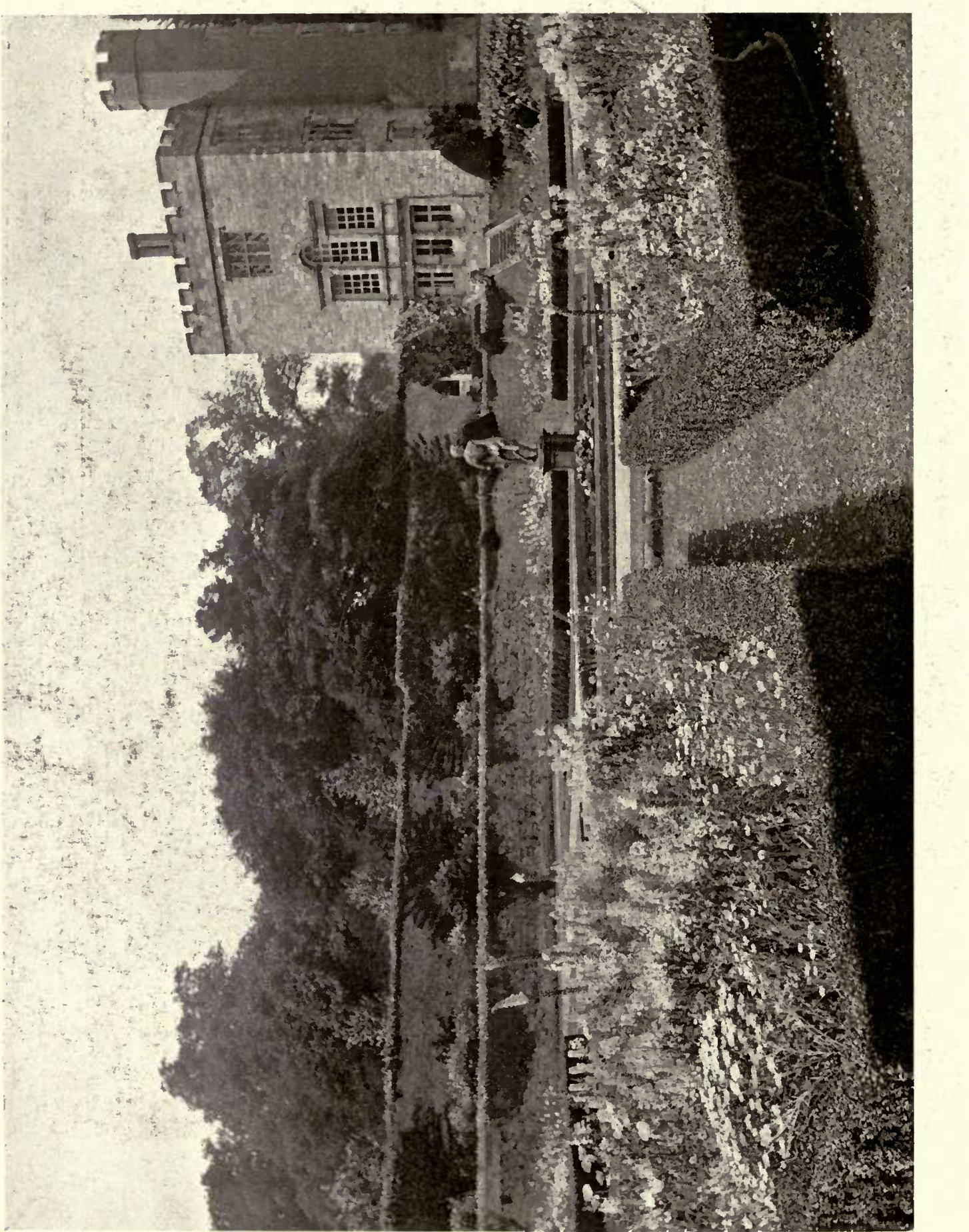




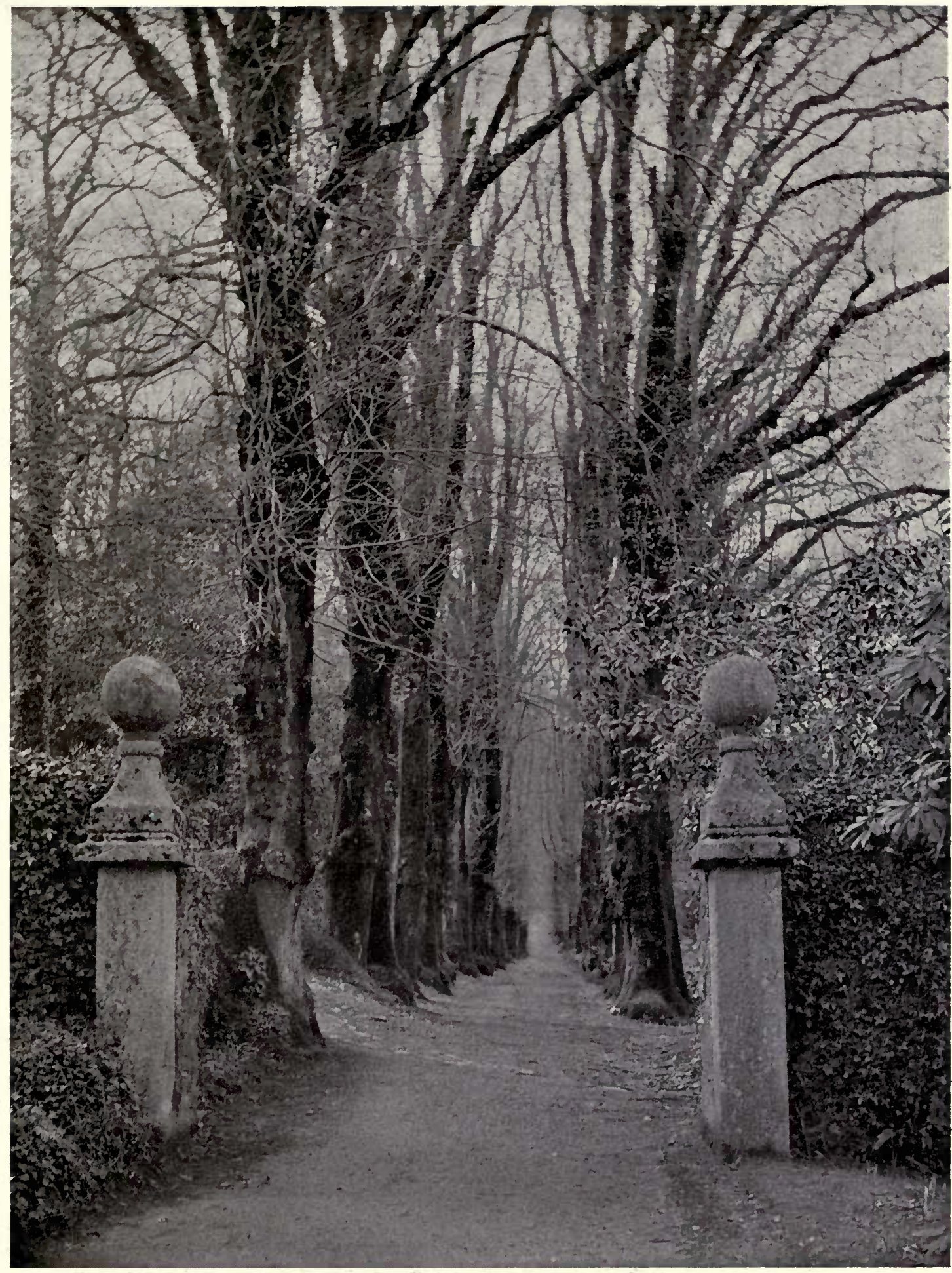



Nof $x^{2}+x^{2}$

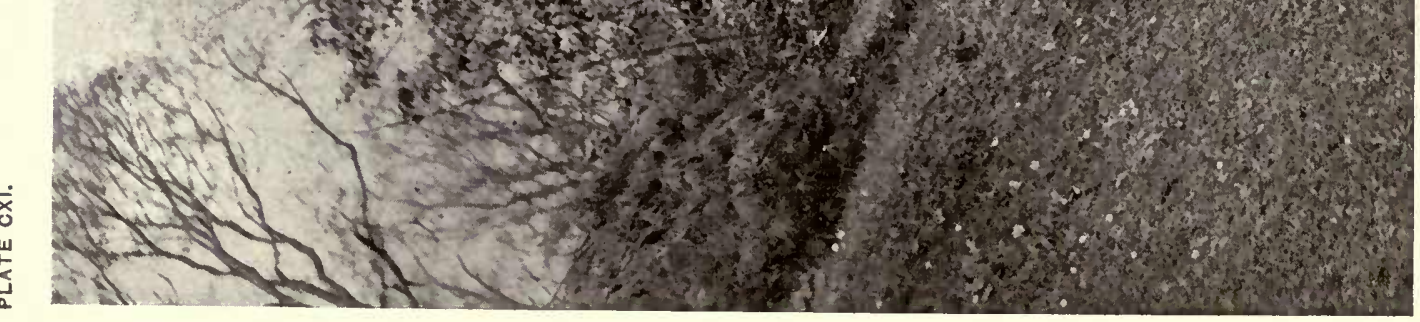




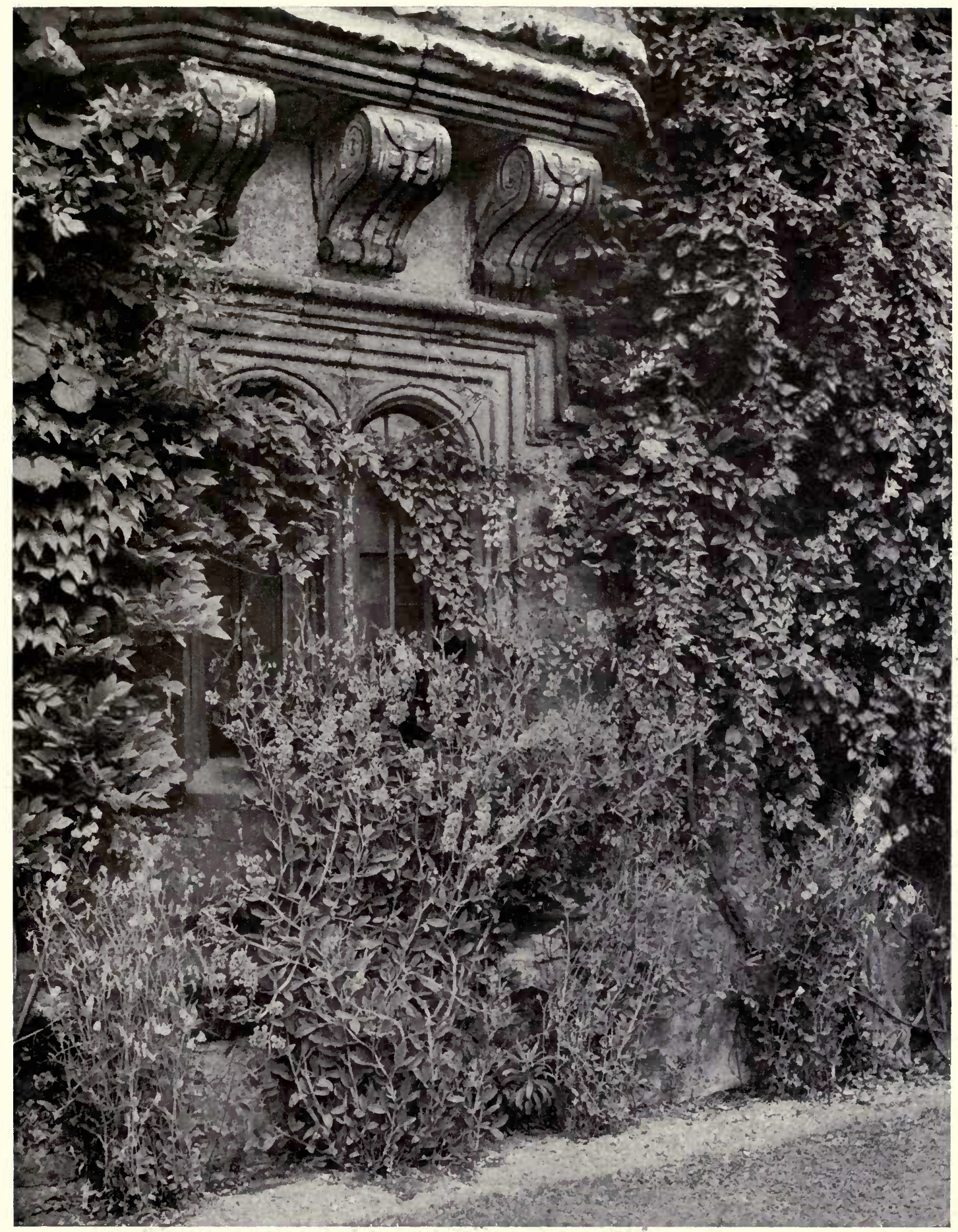




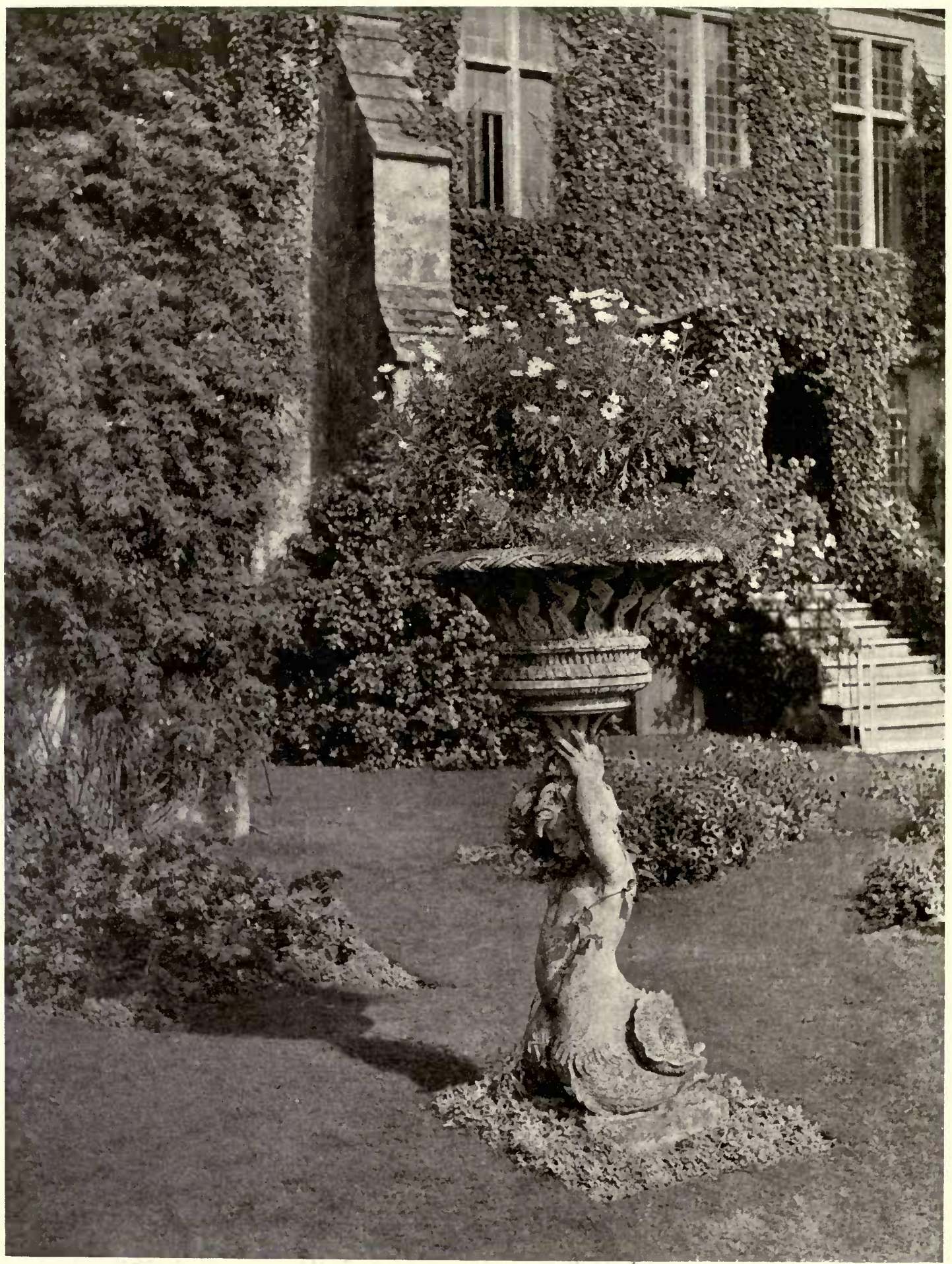




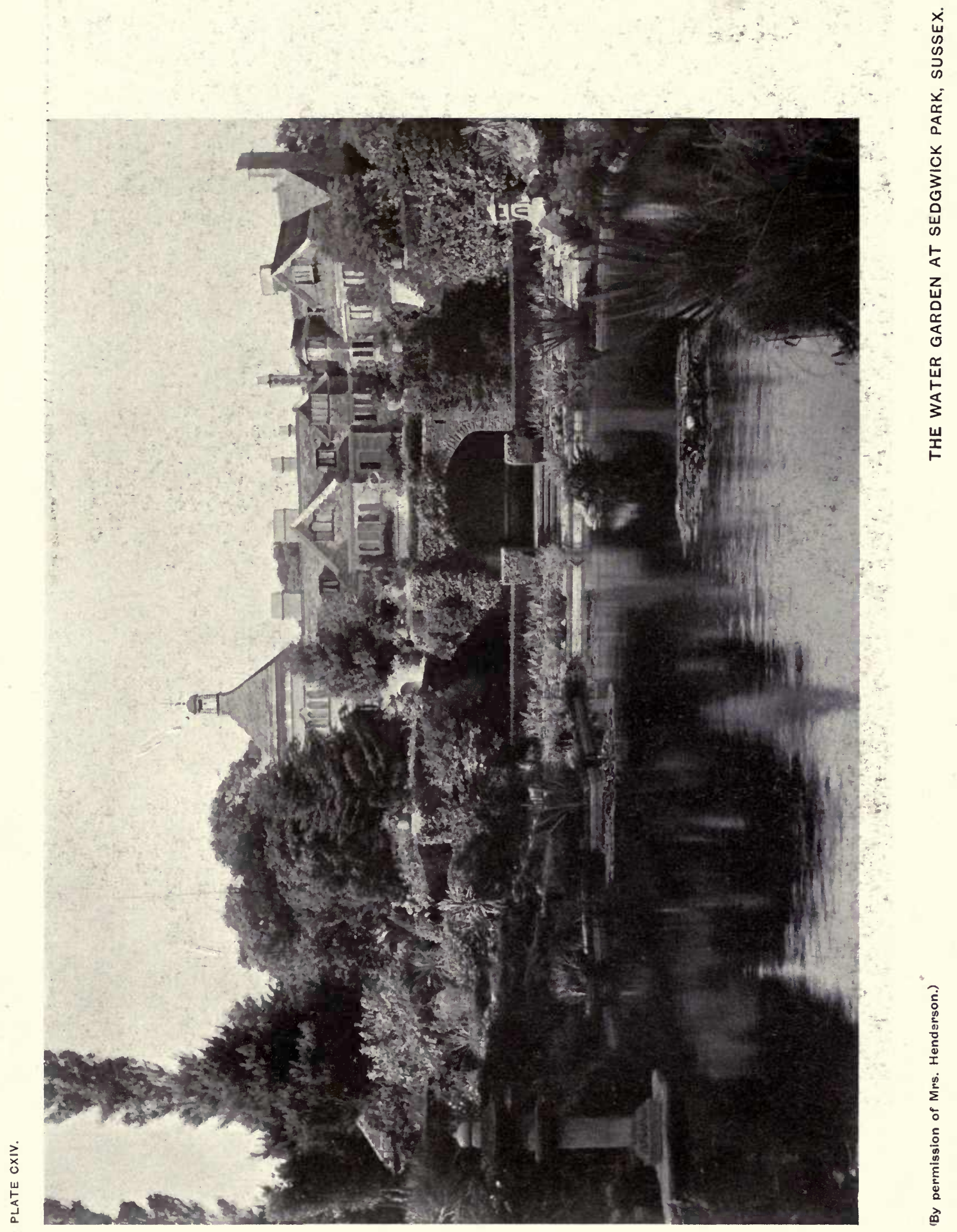



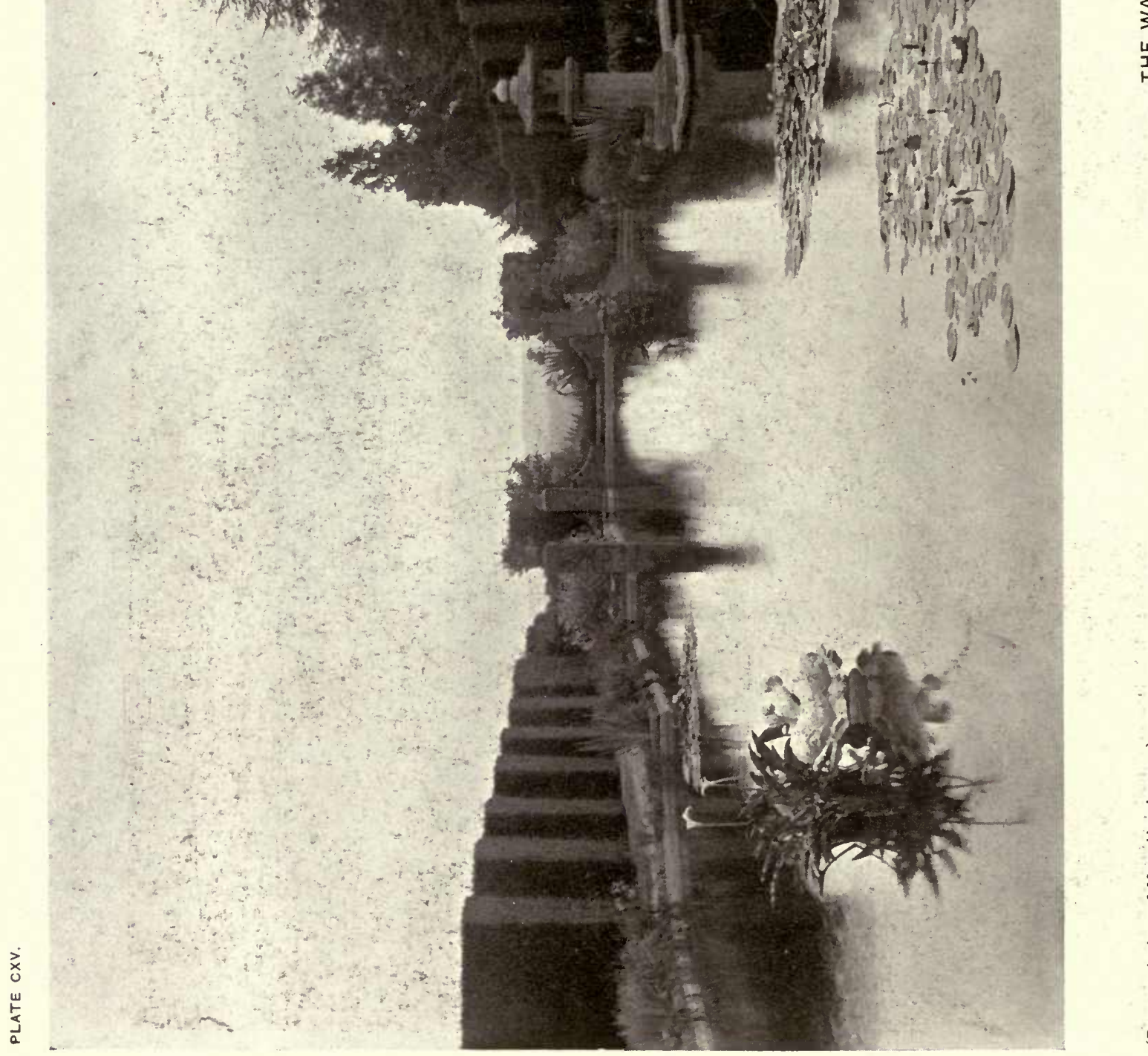

if ben

att 0 


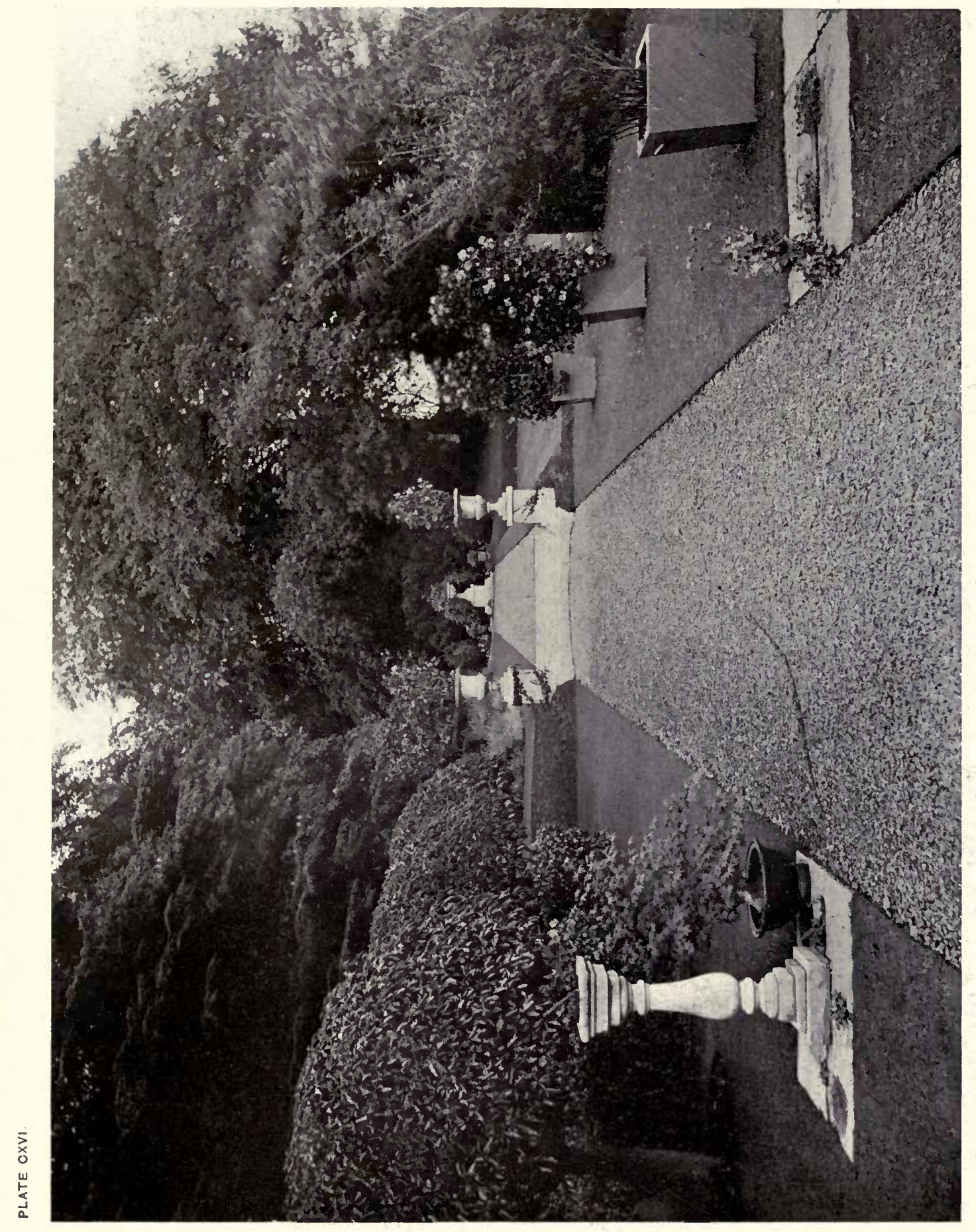

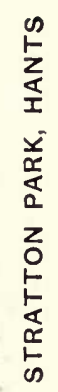

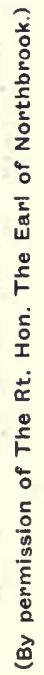




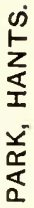

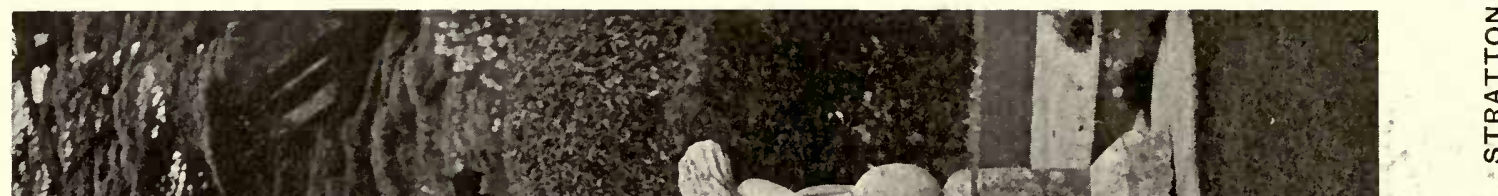
4
ros

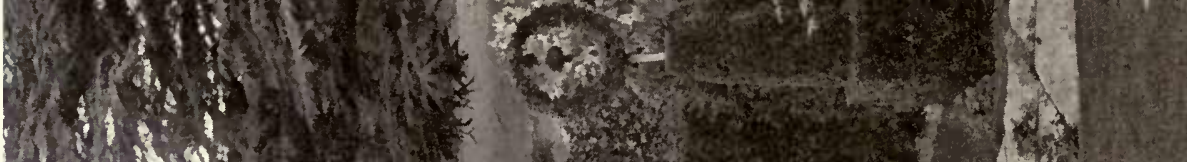

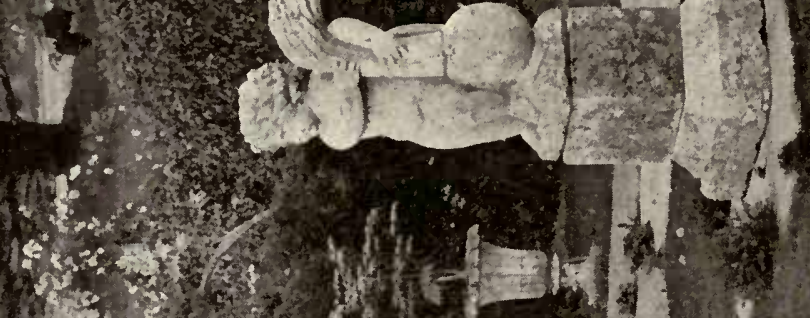

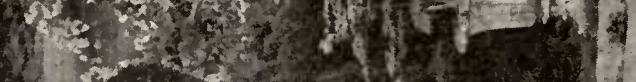
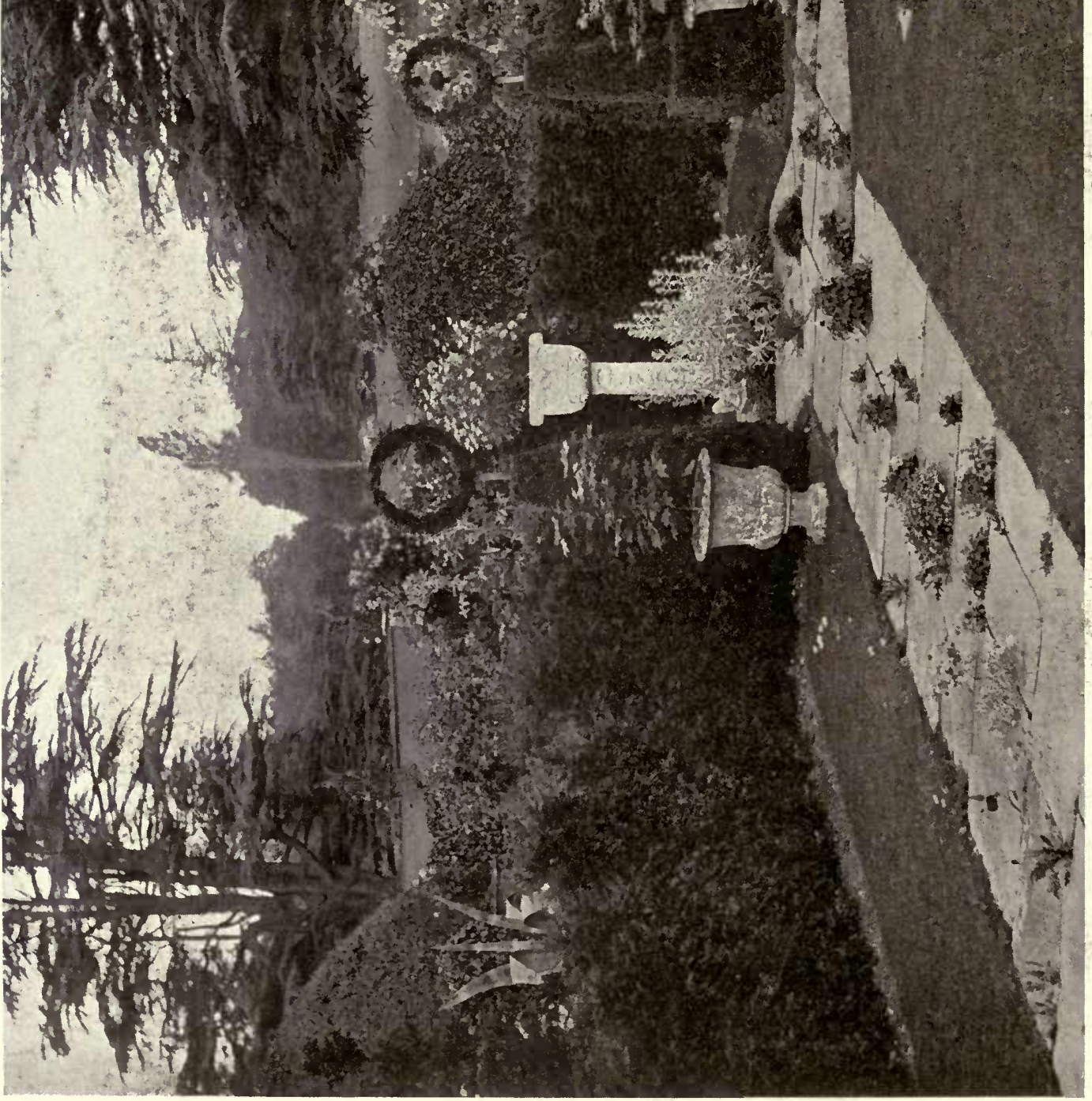


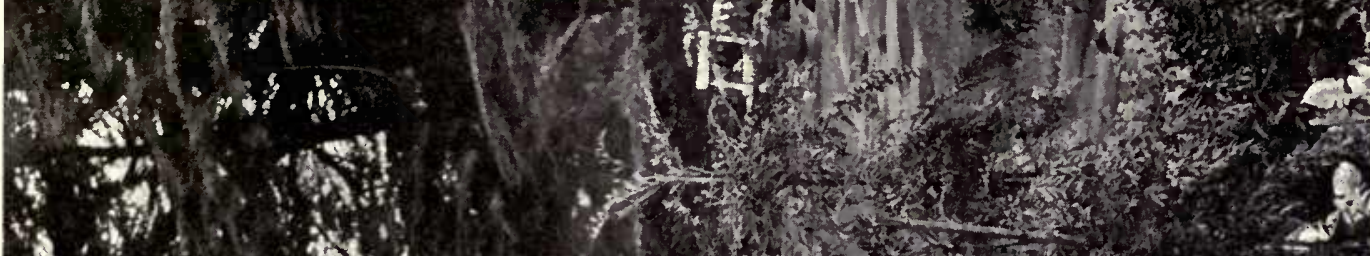

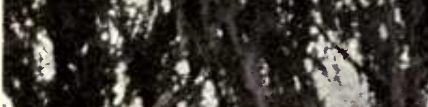

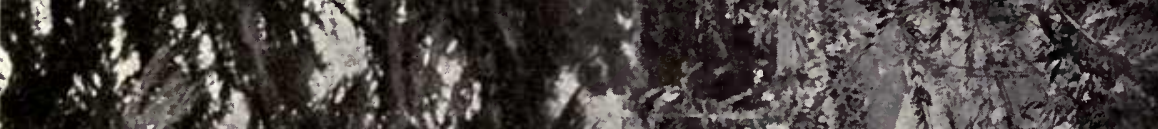

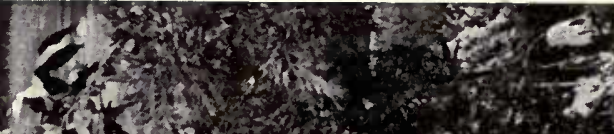

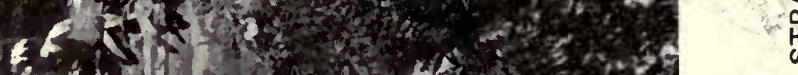

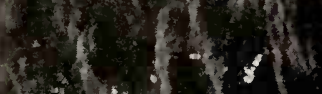

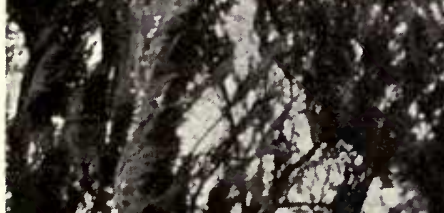

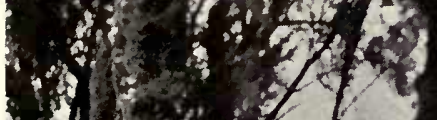
$173 x^{2}+20$

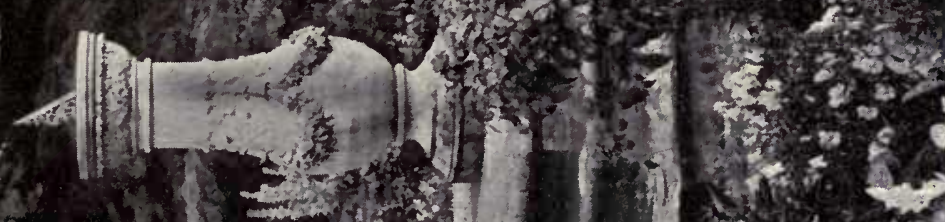

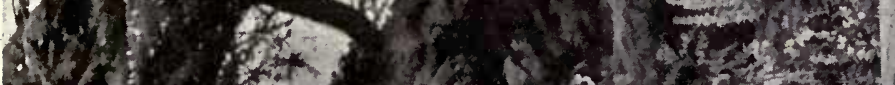

$3(x) \cdots, \sin 2$

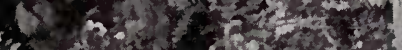

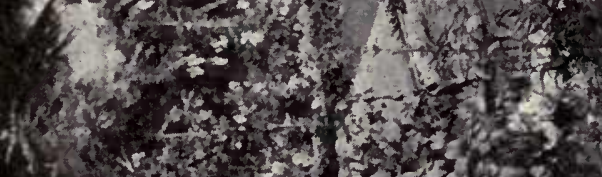
सीकी (1): 20 


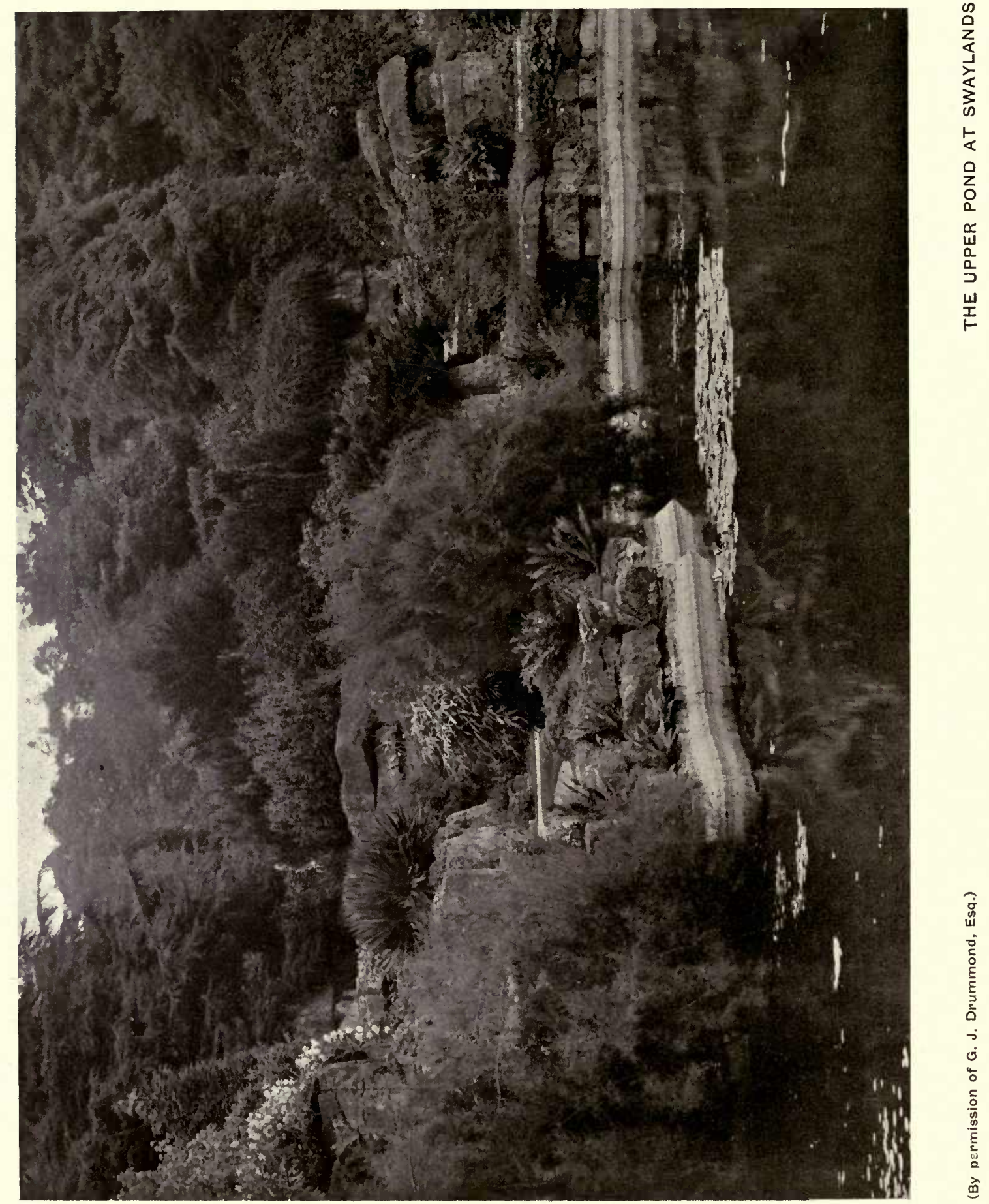




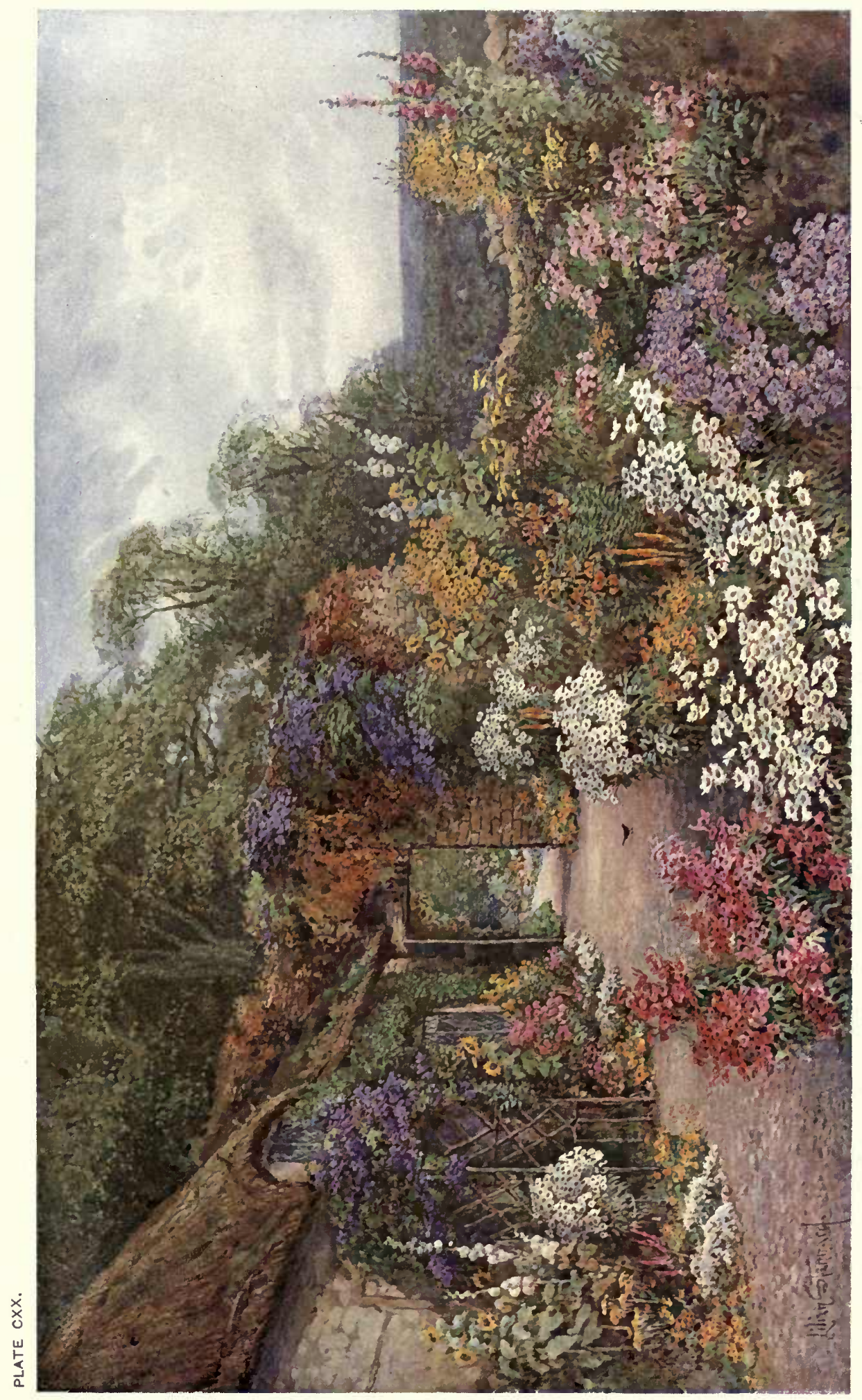


PRARP
OF TEE
VERSITY
OF 


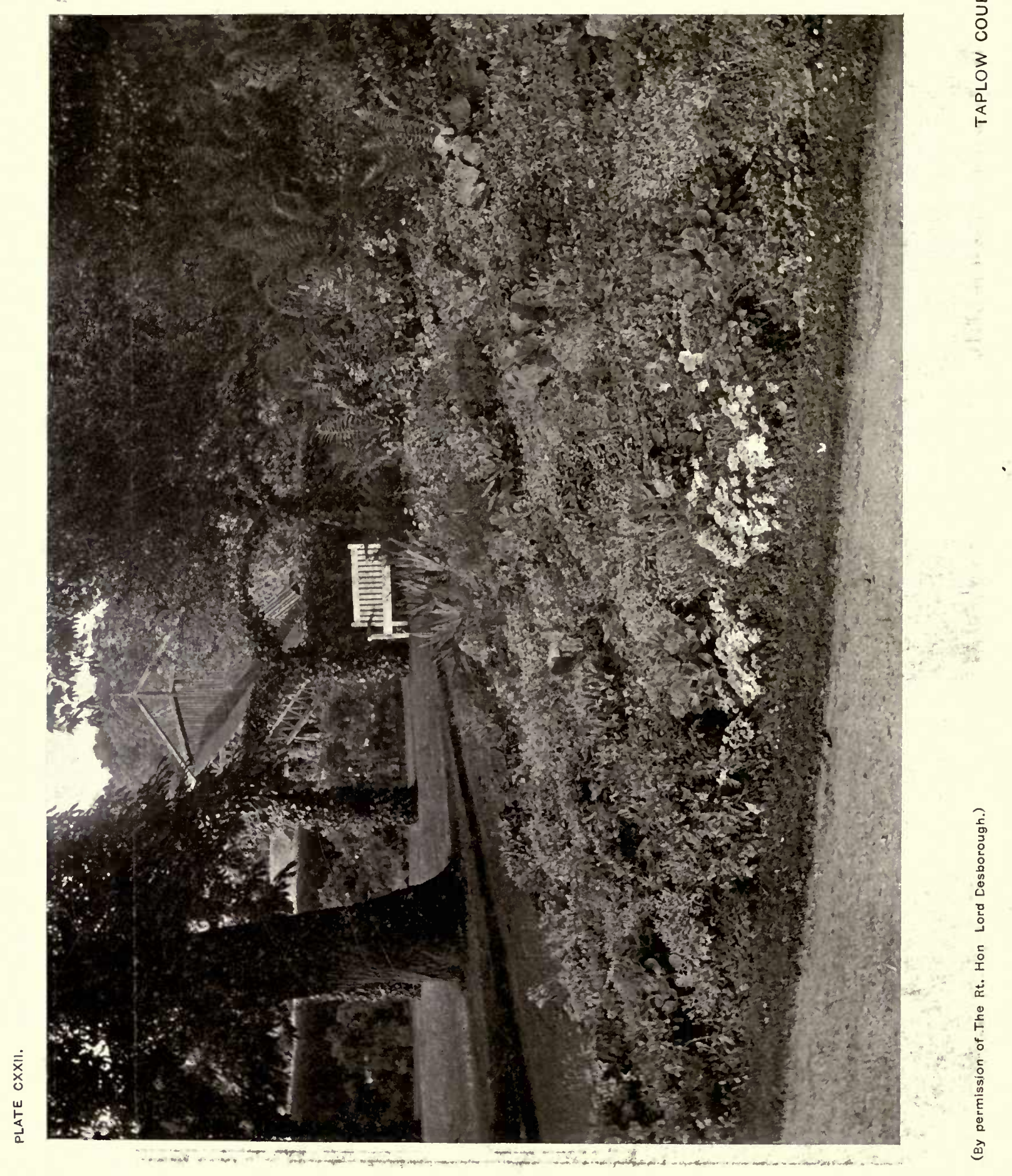




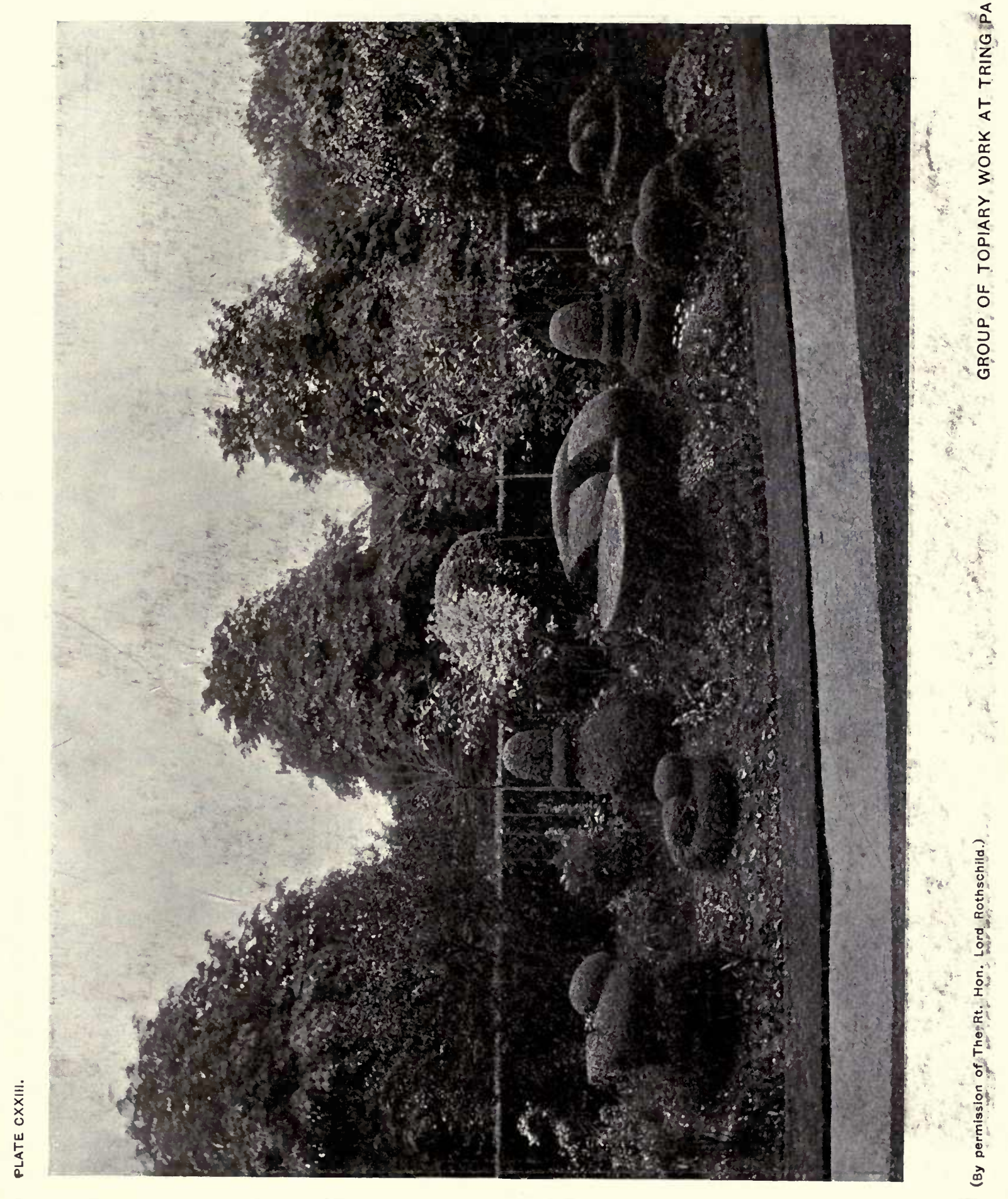




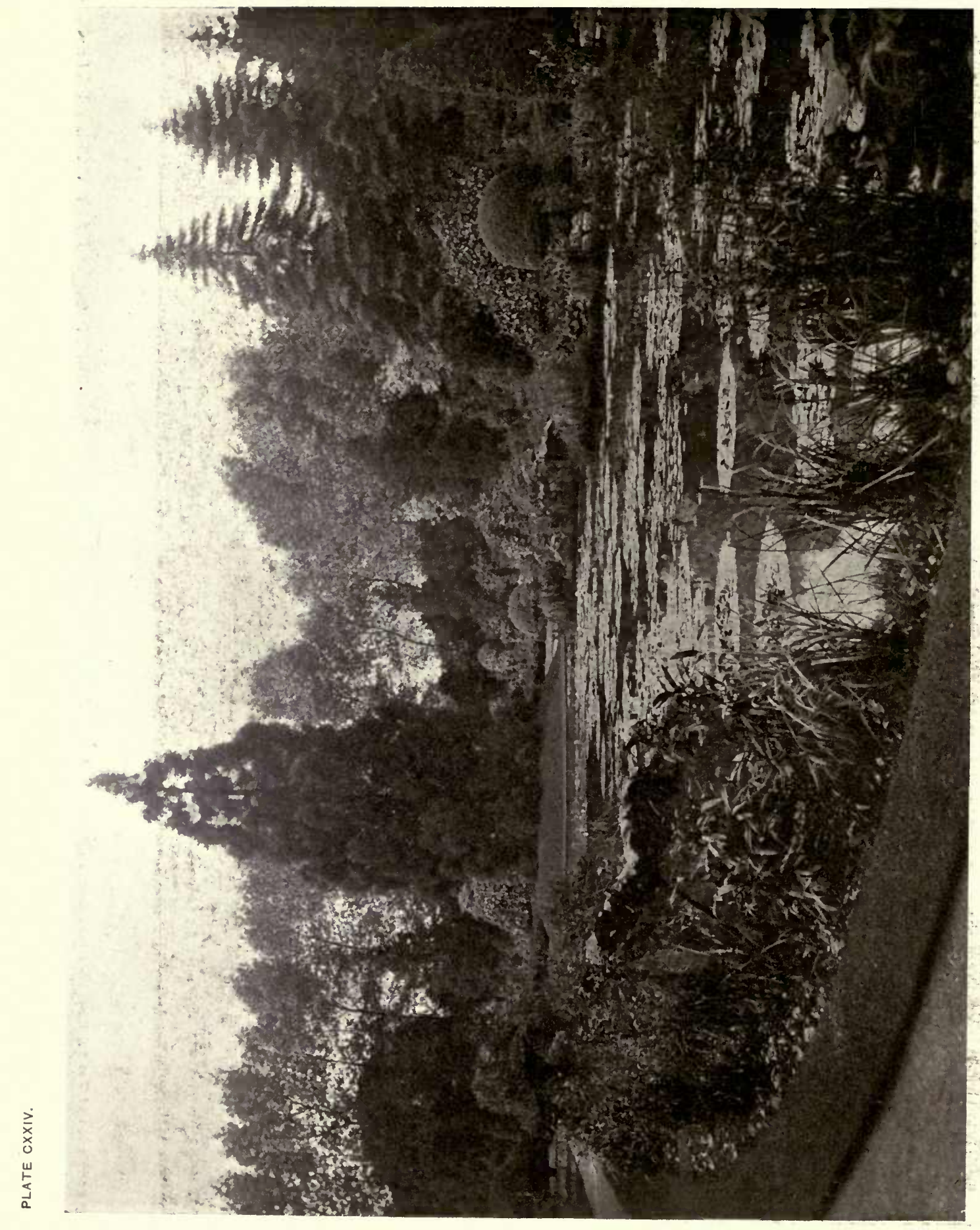

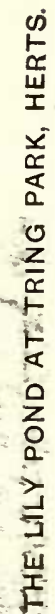

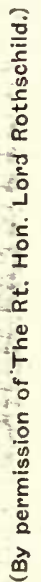




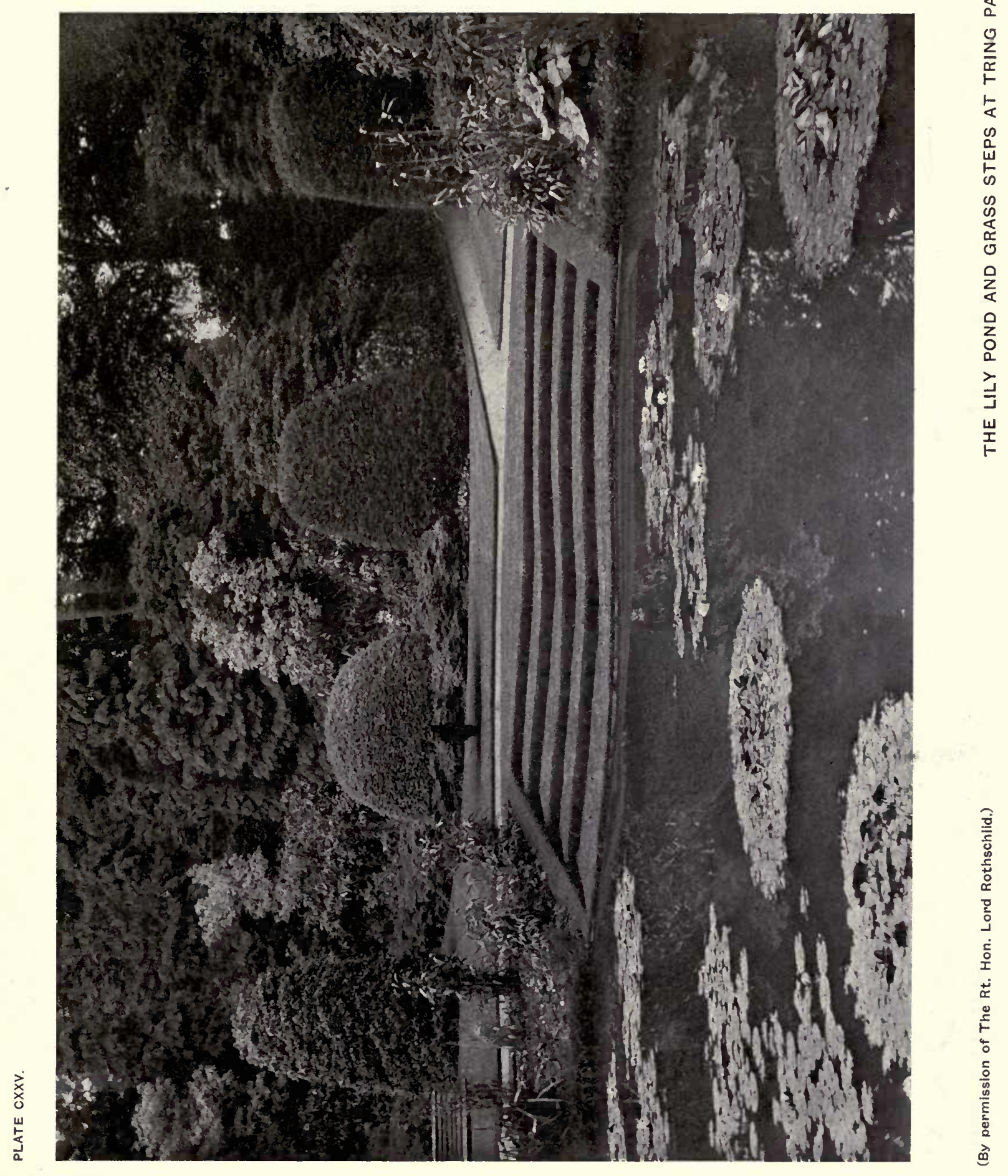




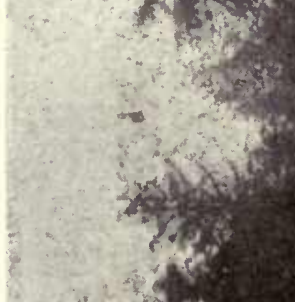

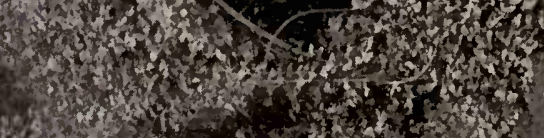

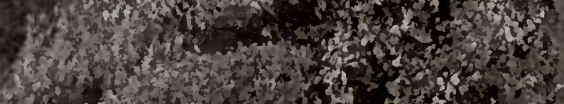

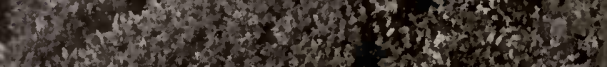

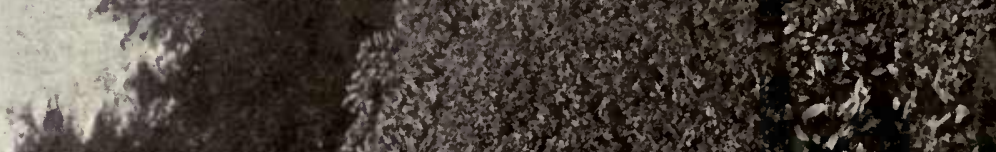

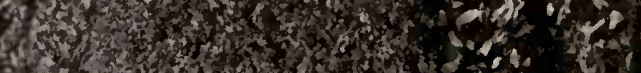




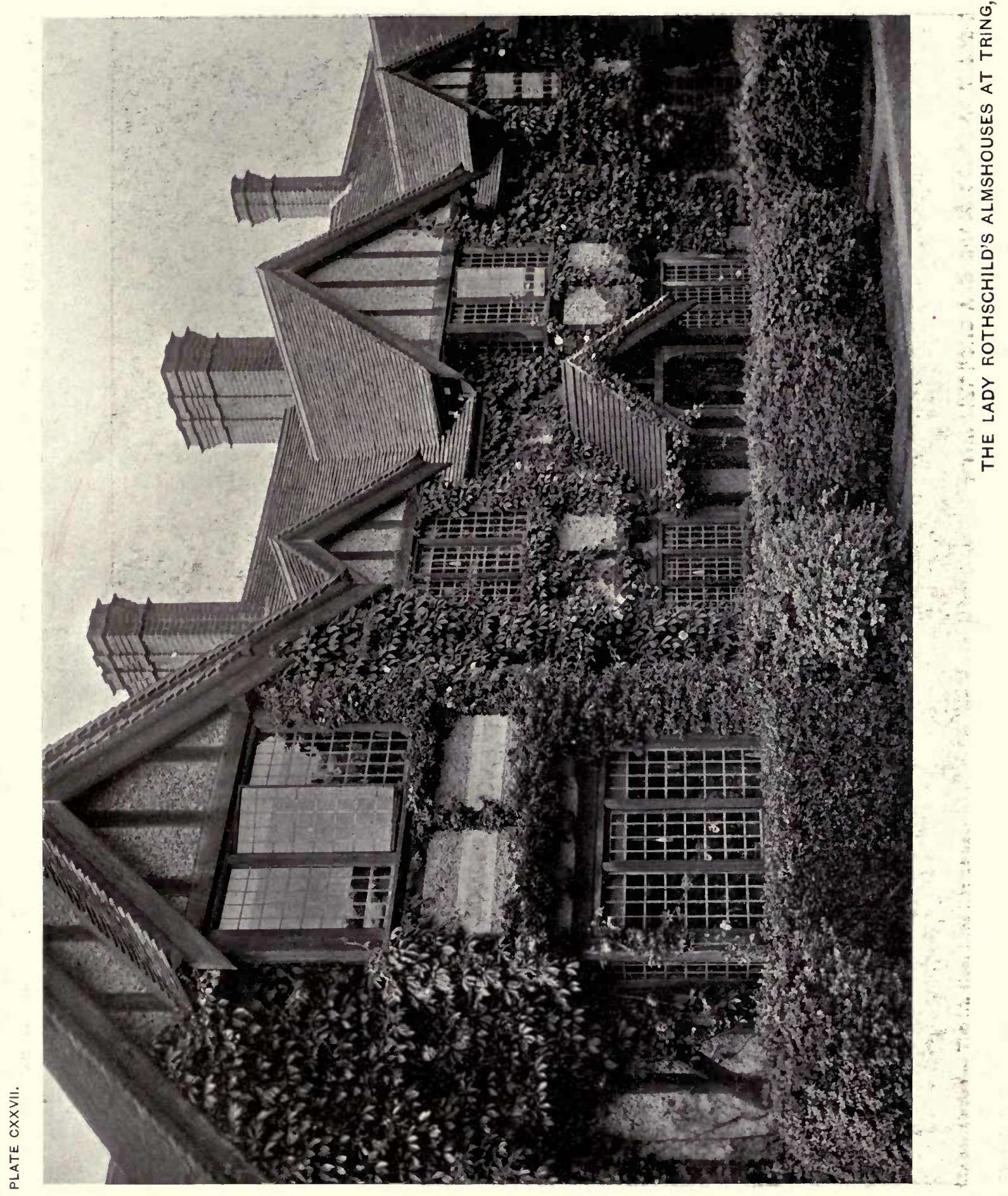




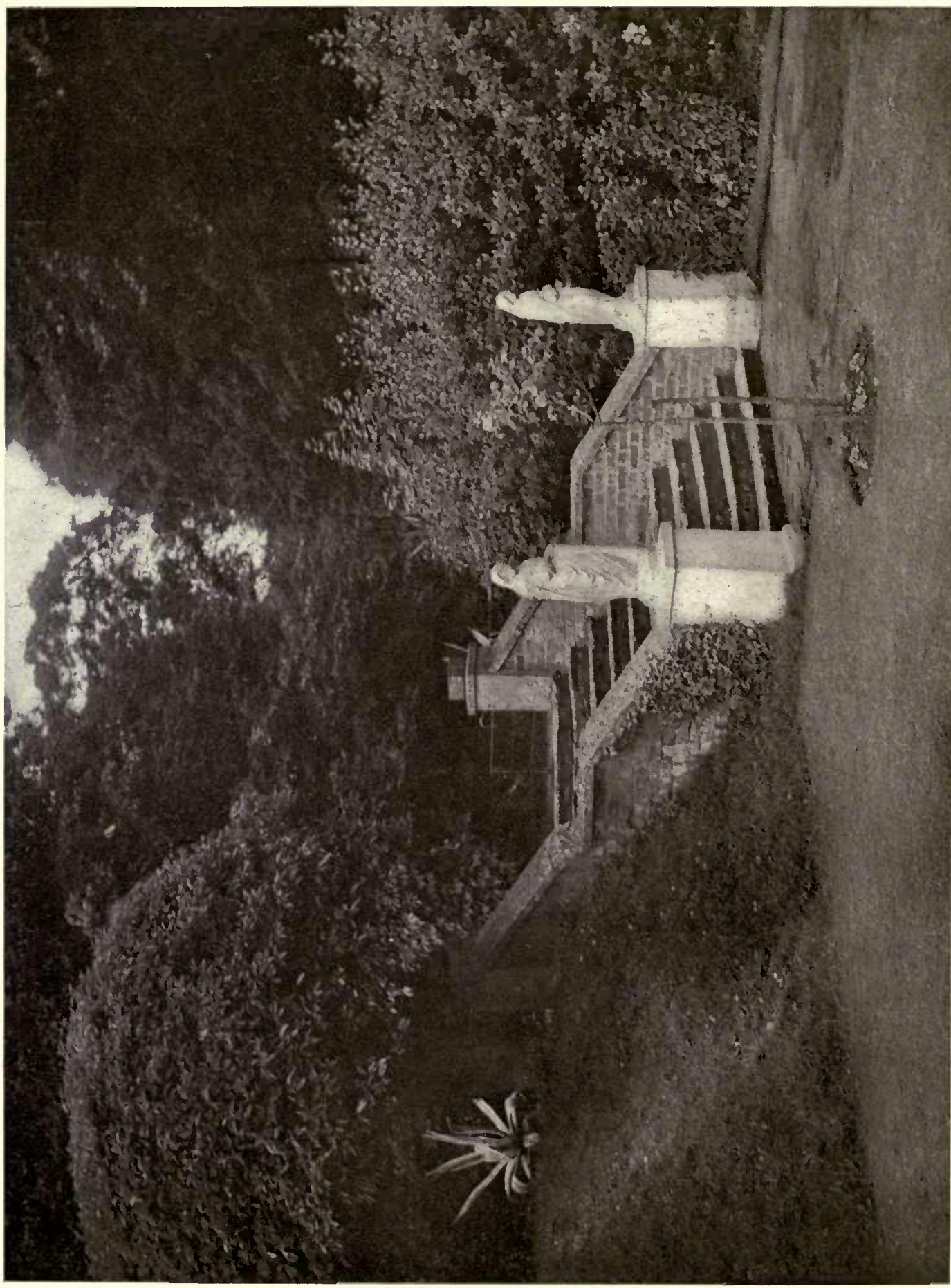




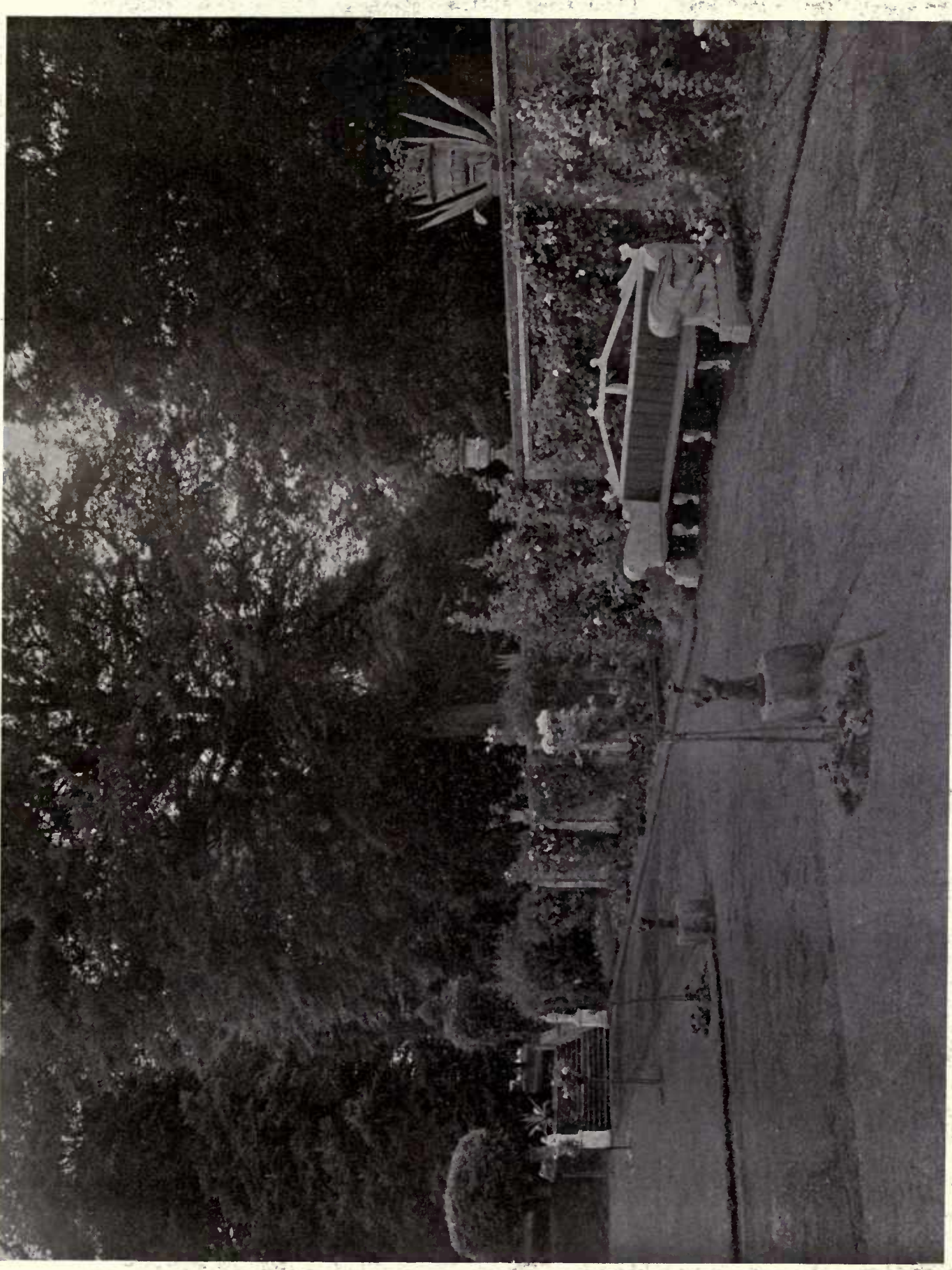

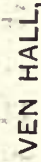




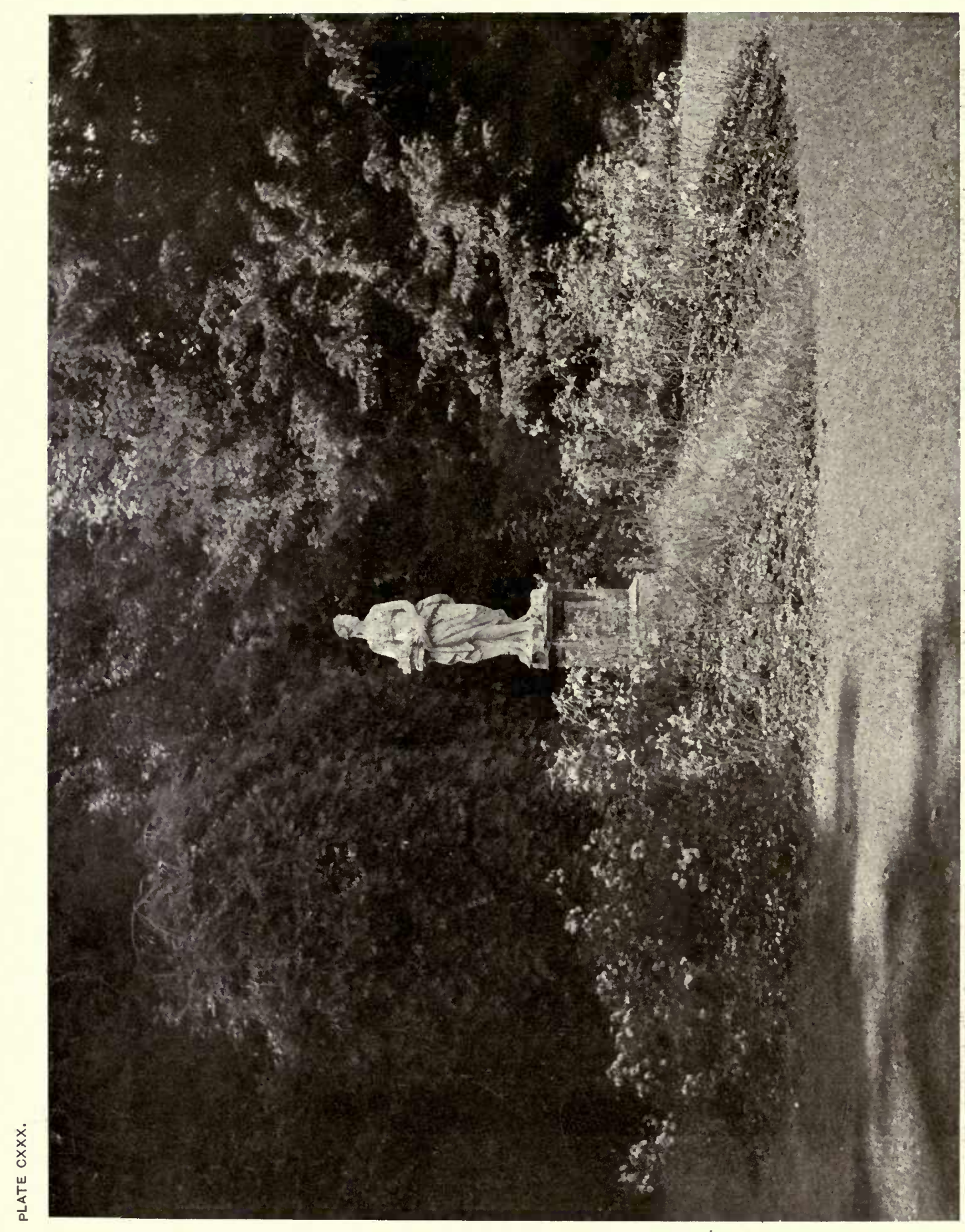

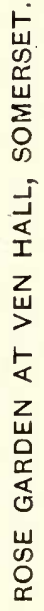




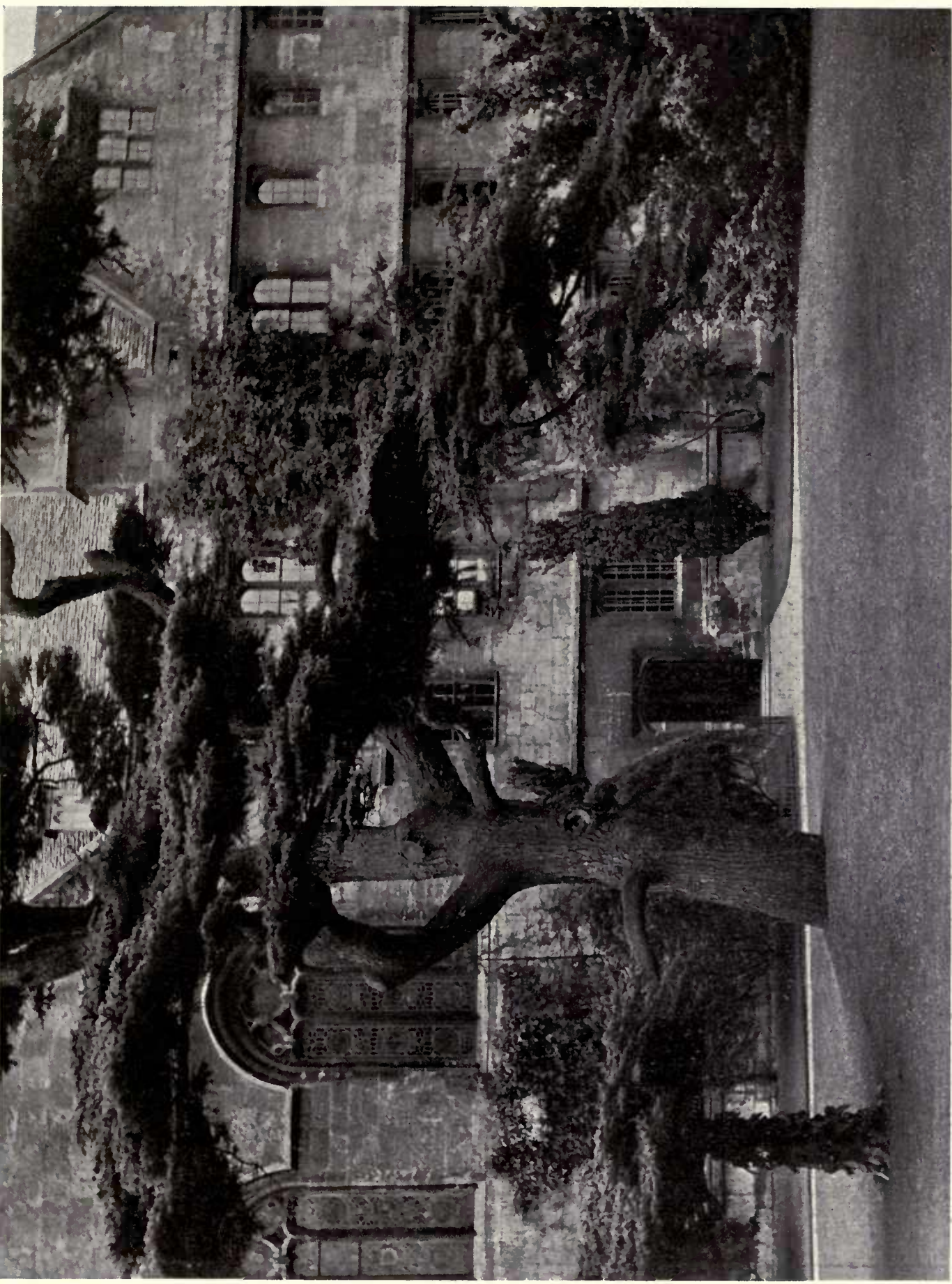

官 

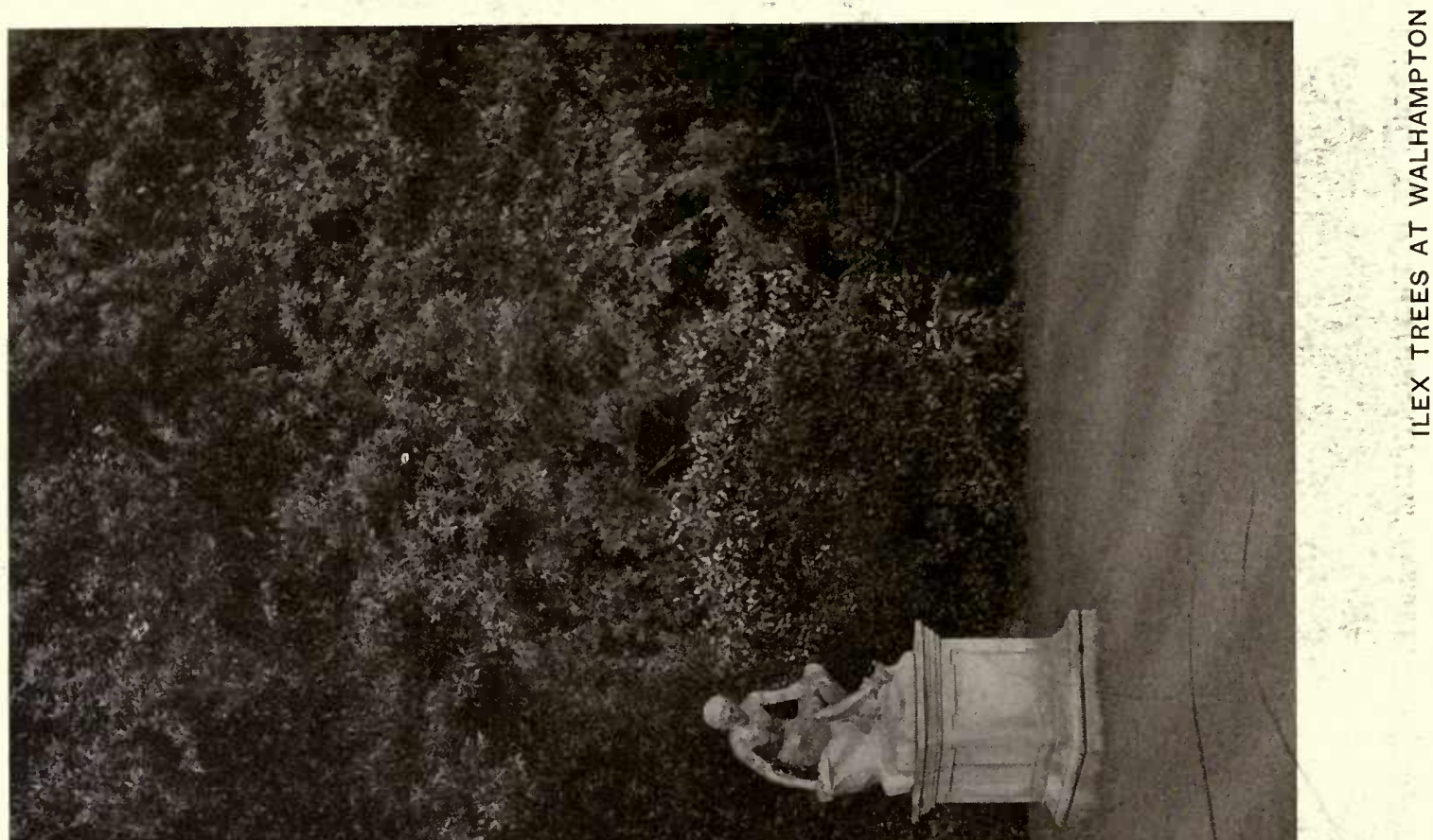

3.t.
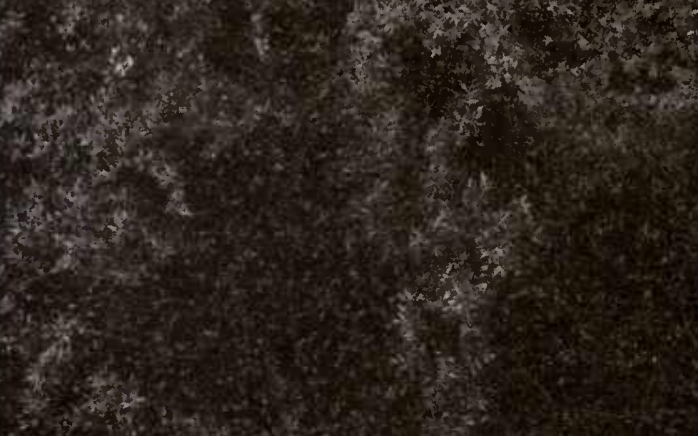

as:

axin
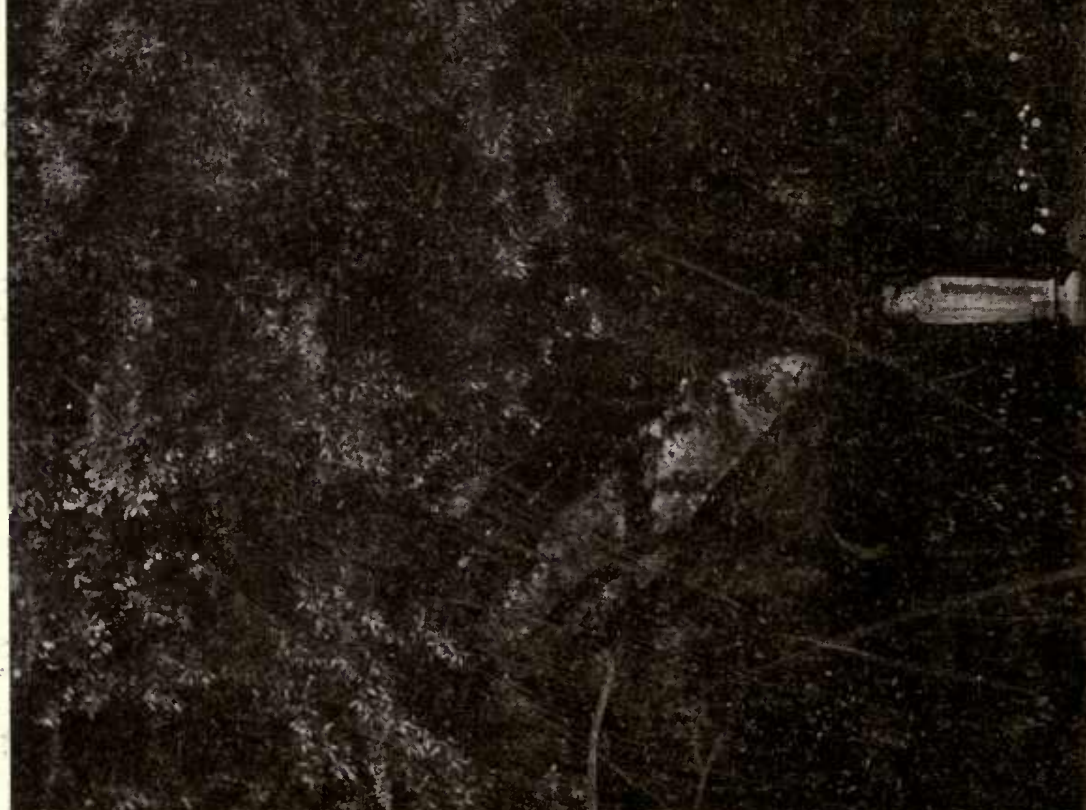



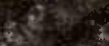




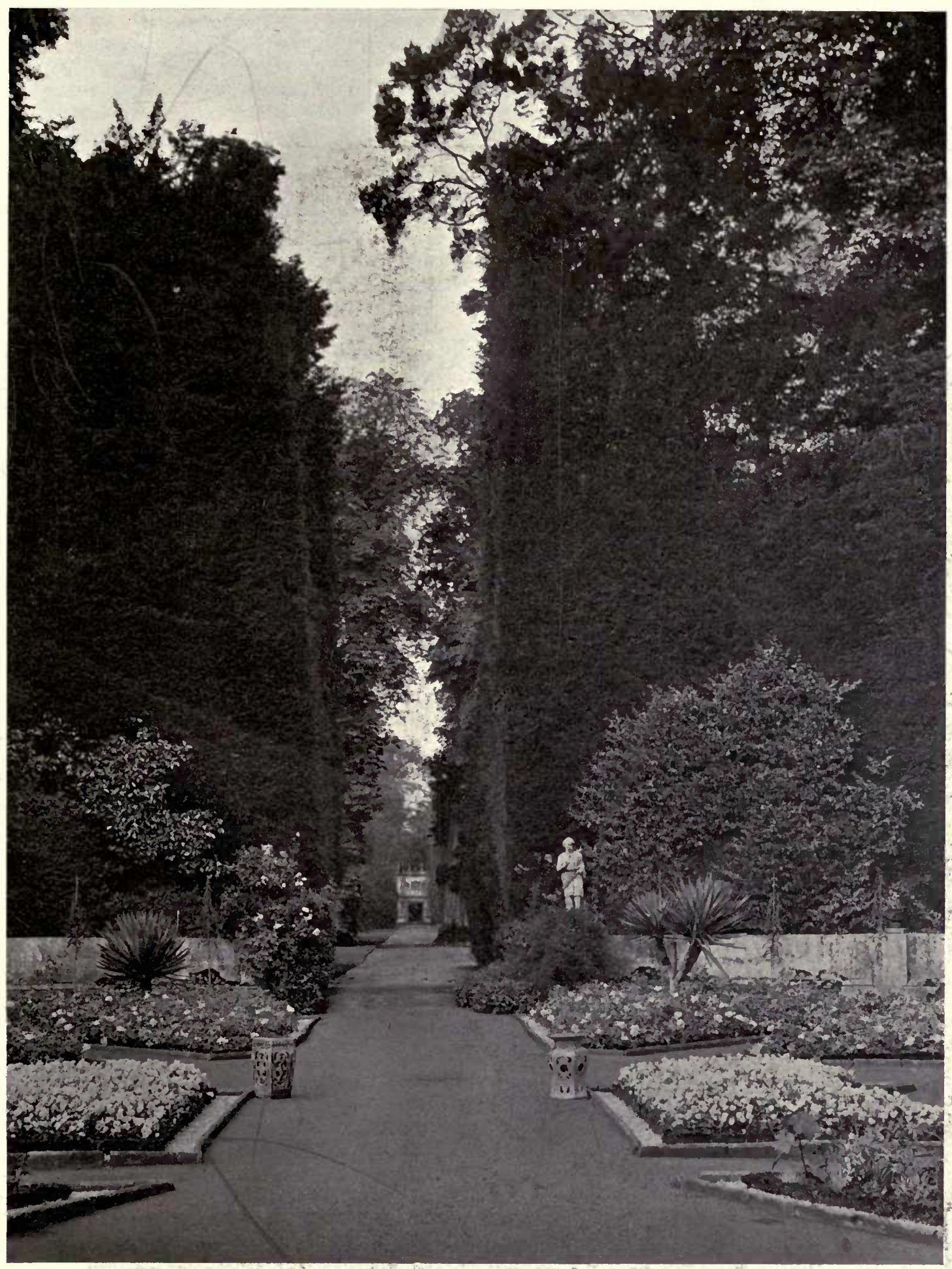




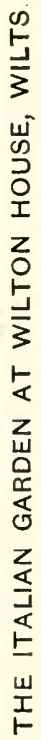

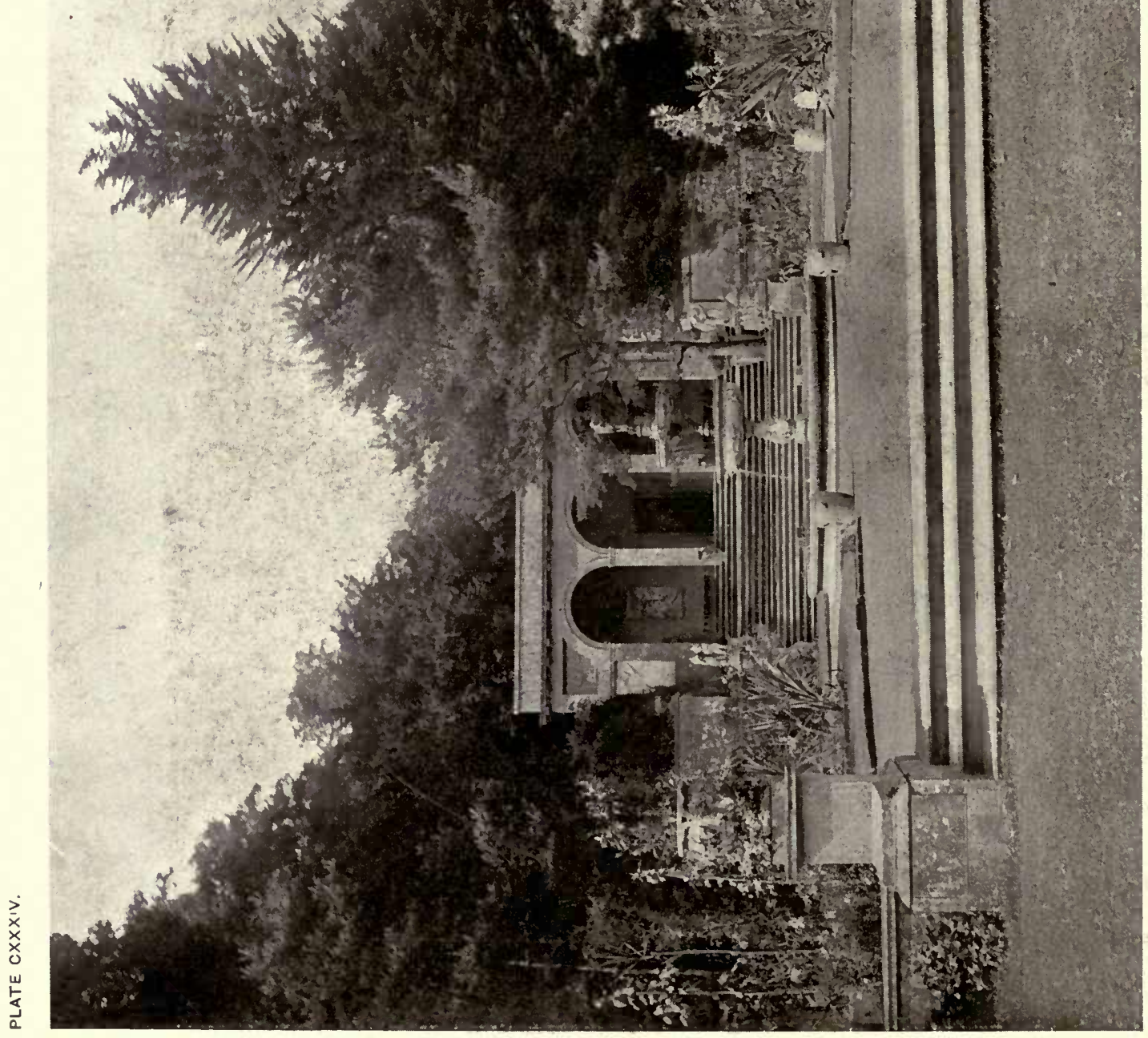




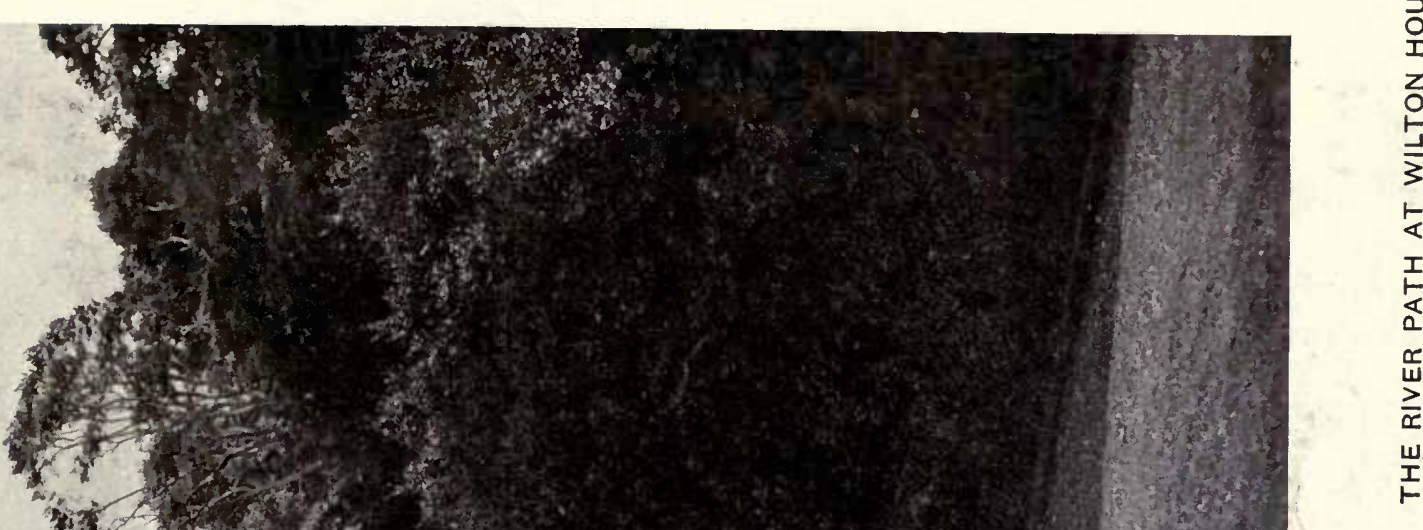
.

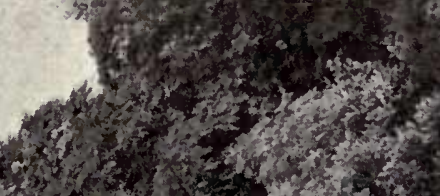

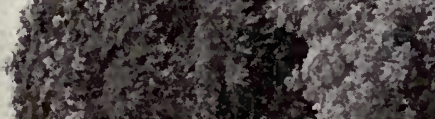

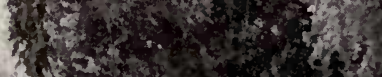
thets?

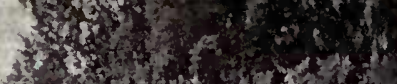

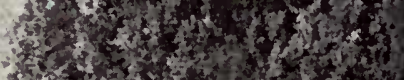

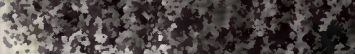

intson

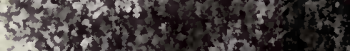
$3,1+1,1$ $+x_{0}-1$

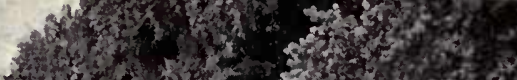

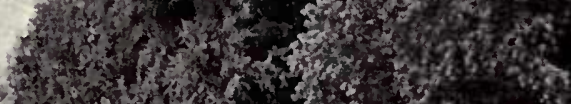

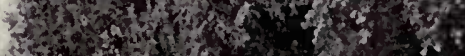

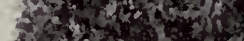
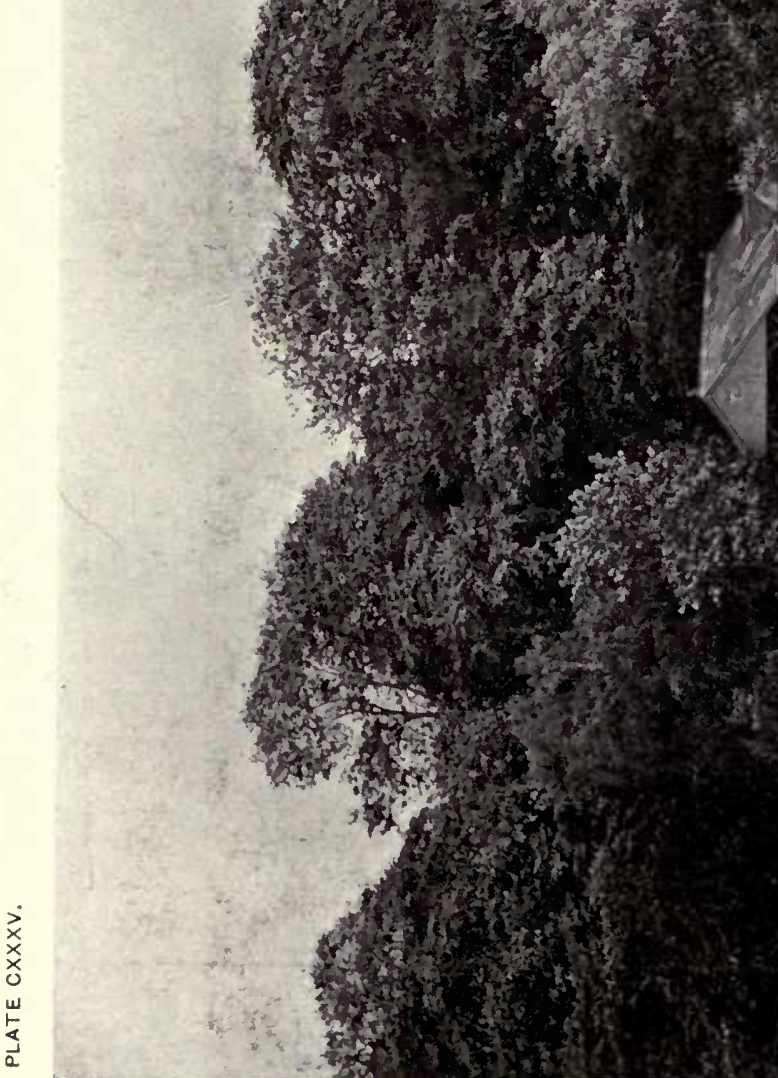
arist a. $R(x+4)$
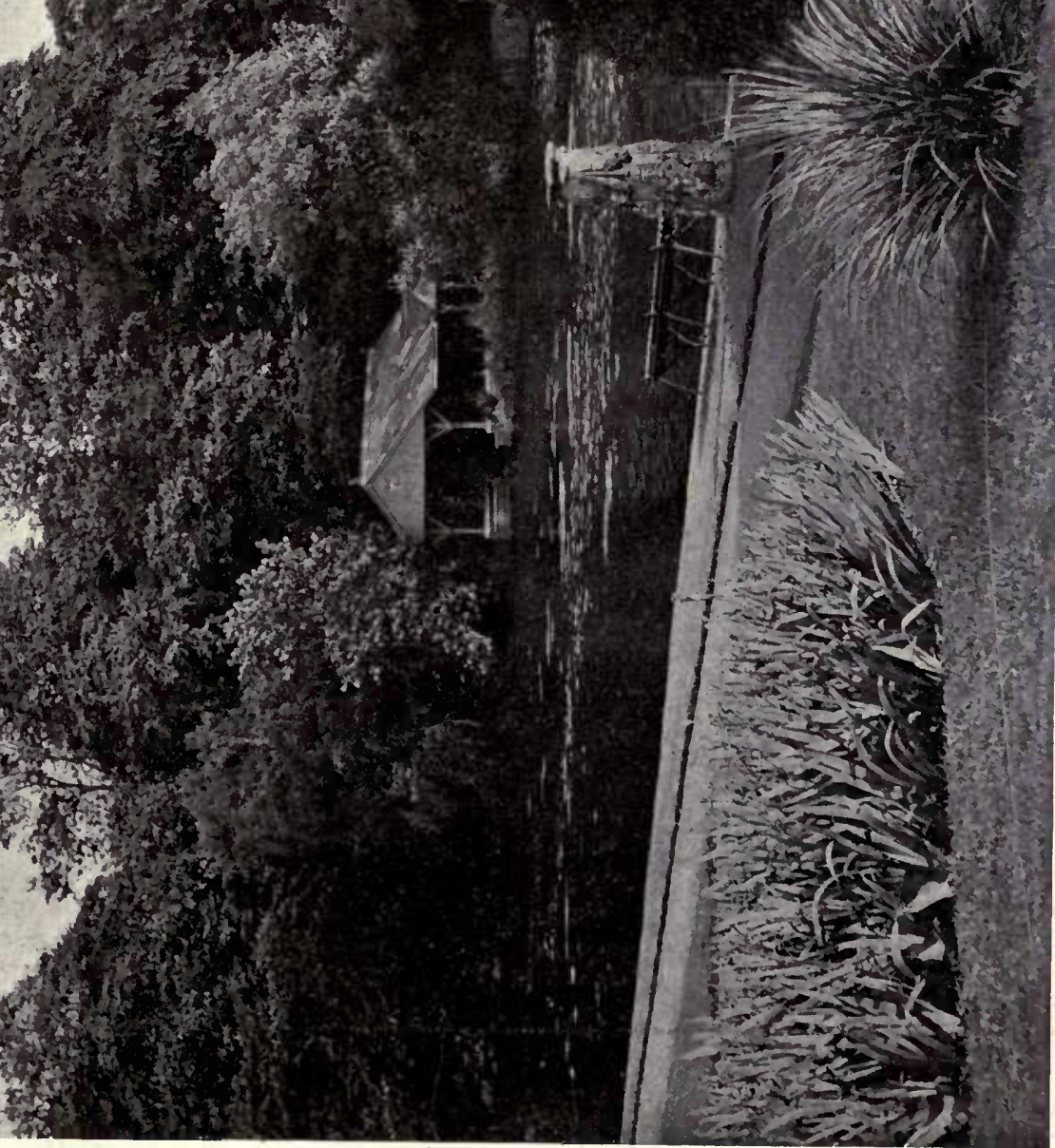

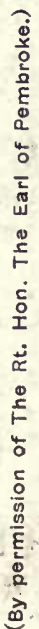

IIBRAA 


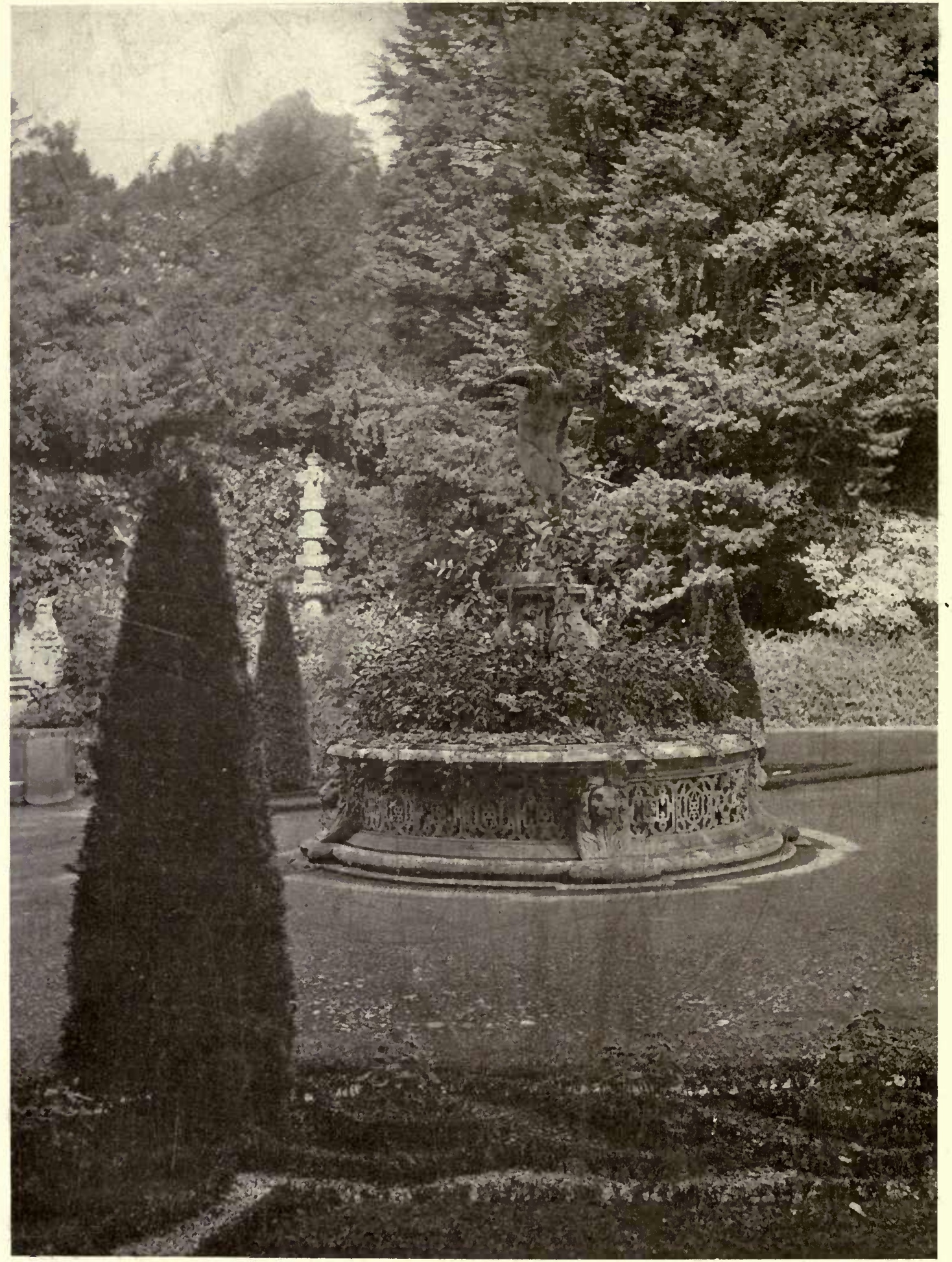




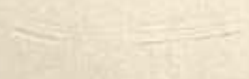





\section{GENERAL LIBRARY}

\section{UNIVERSITY OF CALIFORNIA-BERKELEY}

RETURN TO DESK FROM WHICH BORROWED

This book is due on the last date stamped below, or on the date to which renewed.

Renewed books are subject to immediate recall.

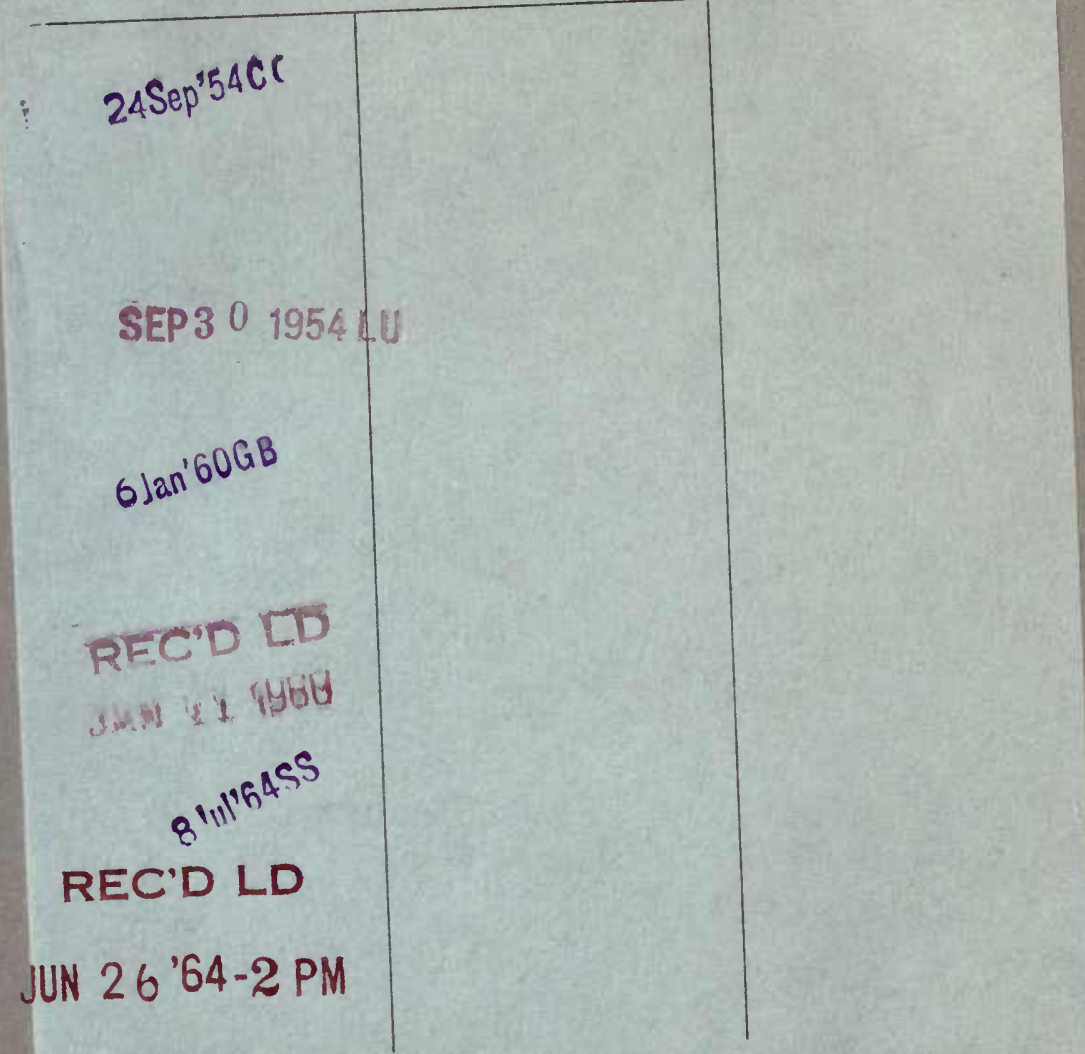




\section{YE 0093i}

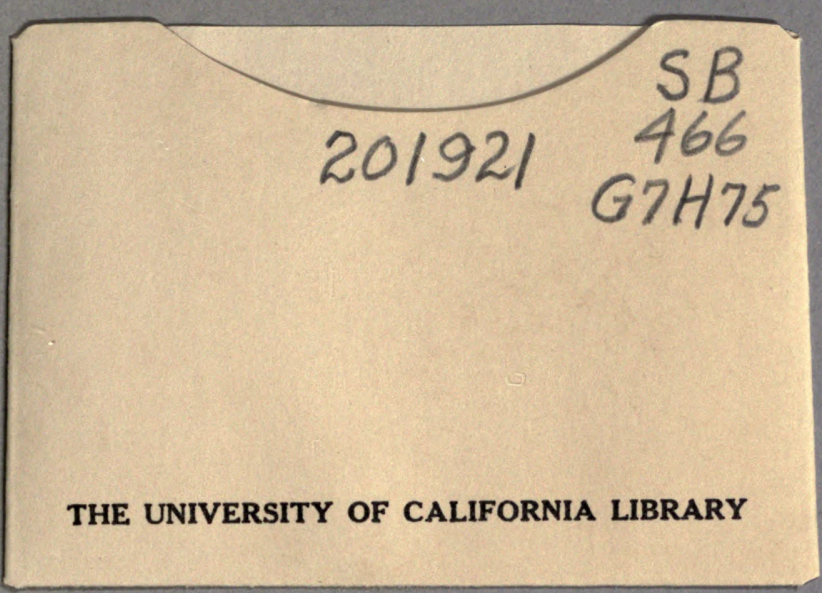


